In cooperation with the U.S.Environmental Protection Agency

\title{
Interpretation of Geophysical Logs, Aquifer Tests, and Water Levels in Wells in and Near the North Penn Area 7 Superfund Site, Upper Gwynedd Township, Montgomery County, Pennsylvania, 2000-02
}
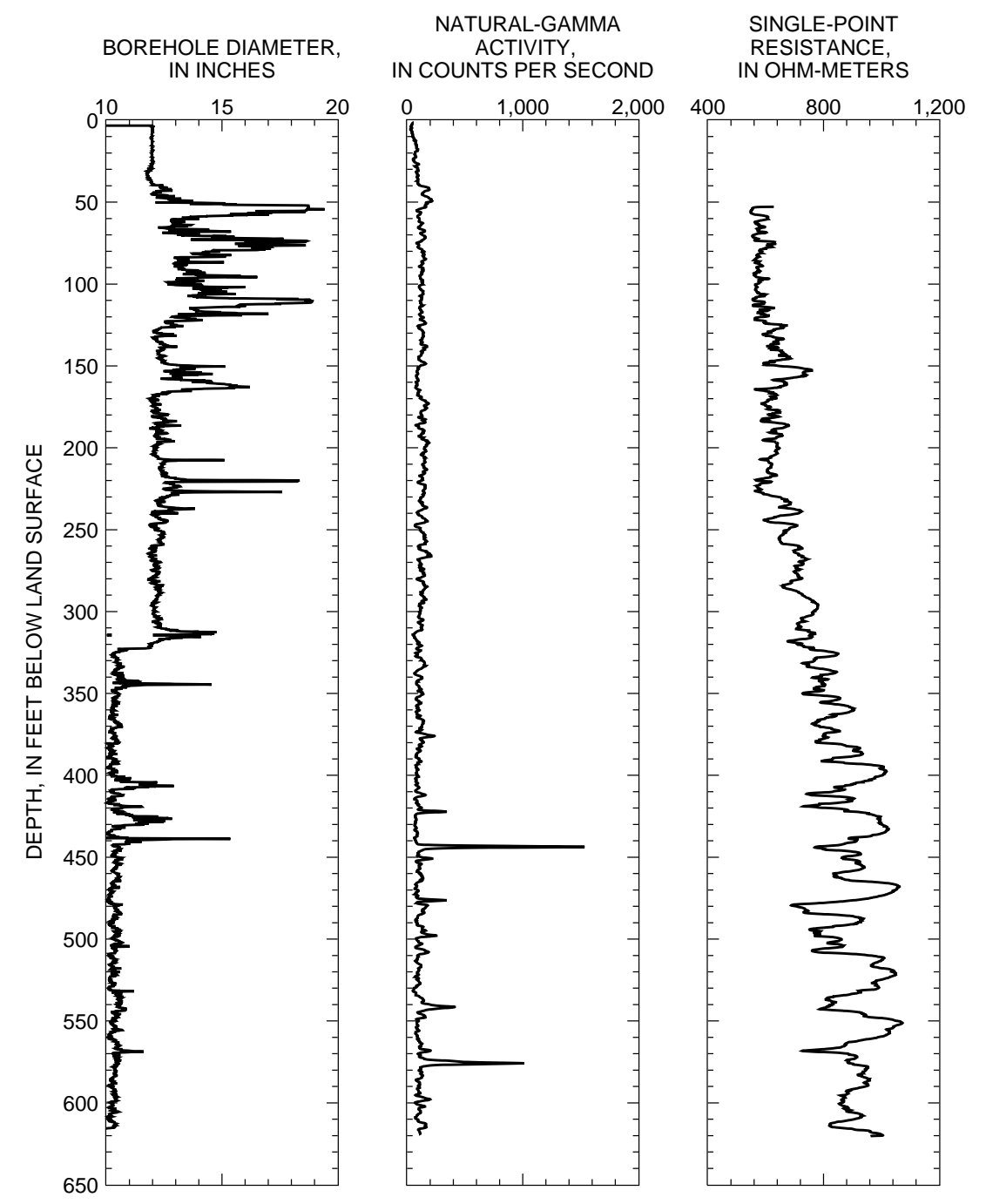

FLUID TEMPERATURE,
IN DEGREES CELSIUS

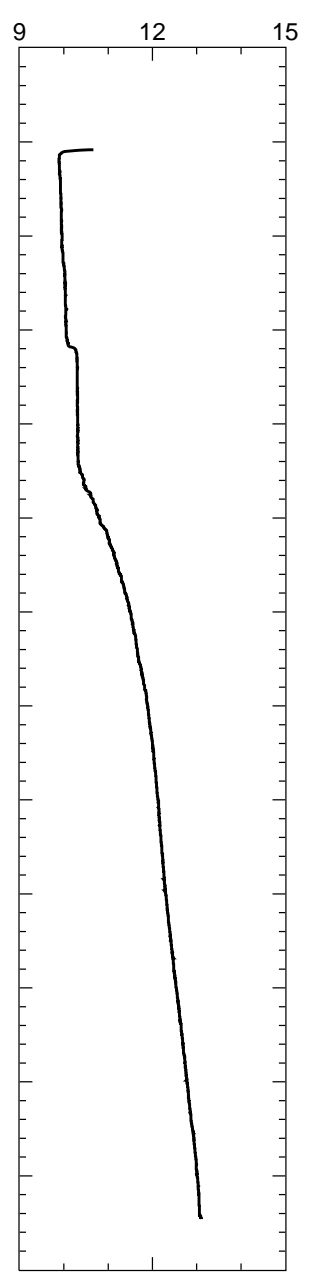

Scientific Investigations Report 2005-5069 


\section{Interpretation of Geophysical Logs, Aquifer Tests, and Water Levels in Wells in and Near the North Penn Area 7 Superfund Site, Upper Gwynedd Township, Montgomery County, Pennsylvania, 2000-02}

By Lisa A. Senior, Peter J. Cinotto, Randall W. Conger, Philip H. Bird, and Karl A. Pracht

In cooperation with the U.S. Environmental Protection Agency

Scientific Investigations Report 2005-5069

U.S. Department of the Interior

U.S. Geological Survey 


\title{
U.S. Department of the Interior Gale A. Norton, Secretary \\ U.S. Geological Survey \\ P. Patrick Leahy, Acting Director
}

\author{
U.S. Geological Survey, Reston, Virginia: 2005
}

For sale by U.S. Geological Survey, Information Services
Box 25286, Denver Federal Center
Denver, CO 80225
For more information about the USGS and its products:
Telephone: 1-888-ASK-USGS
World Wide Web: http://www.usgs.gov/

Any use of trade, product, or firm names in this publication is for descriptive purposes only and does not imply endorsement by the U.S. Government.

Although this report is in the public domain, permission must be secured from the individual copyright owners to reproduce any copyrighted materials contained within this report.

Suggested citation:

Senior, L.A., Cinotto, P.J., Conger, R.W., Bird, P.H., and Pracht, K.A., 2005, Interpretation of geophysical logs, aquifer tests, and water levels in wells in and near the North Penn Area 7 Superfund Site, Upper Gwynedd Township, Montgomery County, Pennsylvania, 2000-02: U.S. Geological Survey Scientific Investigations Report 2005-5069, 129 p. 


\section{CONTENTS}

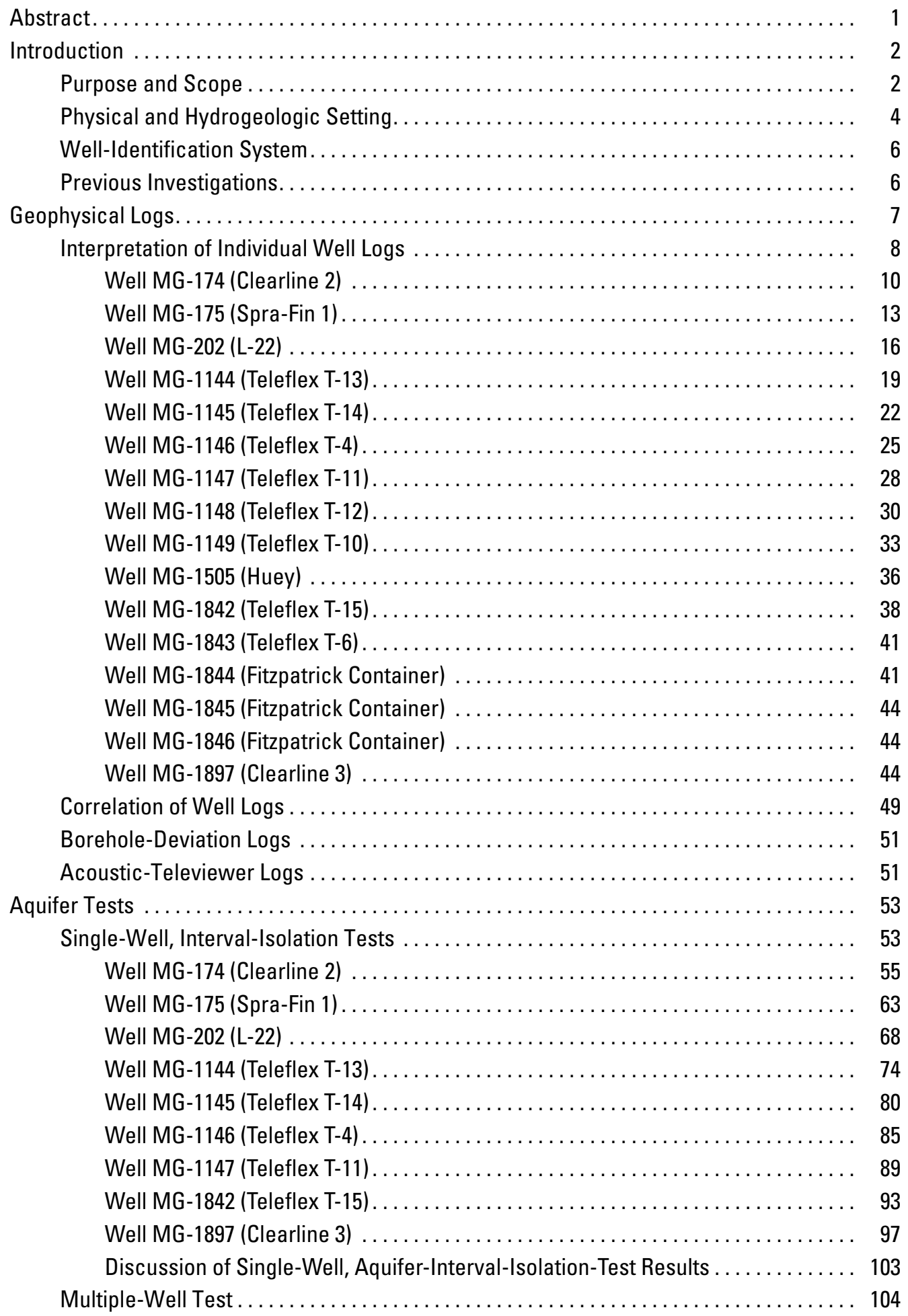




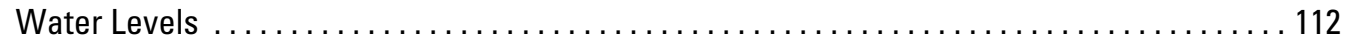

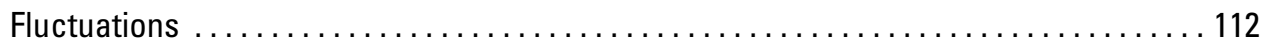

Relation to Streamflow ........................................ 114

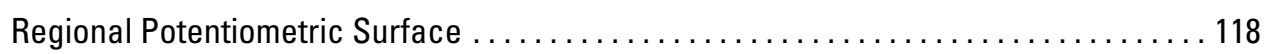

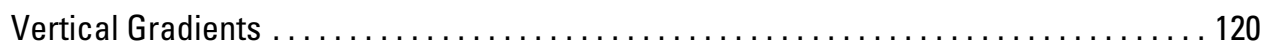

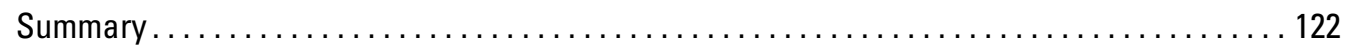

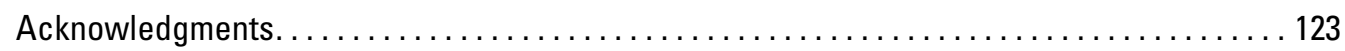

References Cited ..................................................... 123

\section{Figures}

1-4. Maps showing-

1. Location of North Penn Area 7 Superfund site, Upper Gwynedd

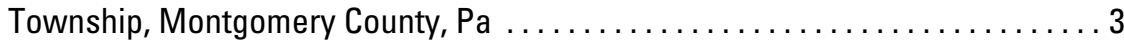

2. Physiographic provinces in Pennsylvania and location of selected wells and precipitation gages in southeastern Pennsylvania in the vicinity of North Penn Area 7 Superfund site $\ldots \ldots \ldots \ldots \ldots \ldots \ldots \ldots \ldots \ldots$

3. Bedrock geology in the vicinity of North Penn Area 7 Superfund site . ....... 5

4. Location of wells with geophysical logs in the vicinity of North Penn Area 7 Superfund site. .......................... 9

5. Borehole geophysical logs and direction of flow under nonpumping and pumping conditions within borehole MG-174 (Clearline 2) ................ 11

6. Borehole-deviation log showing direction and magnitude of hole deviation from water level to the bottom of the borehole for well MG-174 (Clearline 2) . . . . 12

7. Borehole geophysical logs and direction of flow under nonpumping and pumping conditions within borehole MG-175 (Spra-Fin 1) ................ 14

8. Borehole-deviation log showing direction and magnitude of hole deviation from water level to the bottom of the borehole for well MG-175 ............ 16

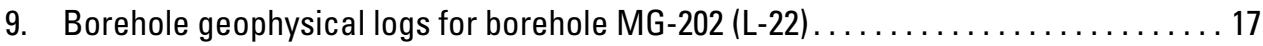

10. Borehole geophysical logs and direction of flow under nonpumping and pumping conditions for the upper 300 feet of the 623-foot borehole MG-202 (L-22) . . .

11. Borehole geophysical logs and direction of flow under nonpumping and pumping conditions within borehole MG-1144 (T-13)

12. Borehole-deviation log showing direction and magnitude of hole deviation from water level to the bottom of the borehole for well MG-1144 (T-13)

13. Borehole geophysical logs and direction of flow under nonpumping and pumping conditions within borehole MG-1145 (T-14).

14. Borehole-deviation log showing direction and magnitude of hole deviation from water level to the bottom of the borehole for well MG-1145 (T-14) . . . . . . 25

15. Borehole geophysical logs and direction of flow under nonpumping and pumping conditions within borehole MG-1146 (T-4) . .

16. Borehole-deviation log showing direction and magnitude of hole deviation from water level to the bottom of the borehole for well MG-1146 (T-4)

17. Borehole geophysical logs and direction of flow under nonpumping and pumping conditions within borehole MG-1147 (T-11). 
18. Borehole-deviation log showing direction and magnitude of hole deviation from water level to the bottom of the borehole for well MG-1147 (T-11) . . . . . . 30

19. Borehole geophysical logs and direction of flow under nonpumping and pumping conditions within borehole MG-1148 (T-12) .................... 31

20. Borehole-deviation log showing direction and magnitude of hole deviation from water level to the bottom of the borehole for well MG-1148 (T-12). . . . . . . 32

21. Borehole geophysical logs and direction of flow under nonpumping and pumping conditions within borehole MG-1149 (T-10) .................. 34

22. Borehole-deviation log showing direction and magnitude of hole deviation from water level to the bottom of the borehole for well MG-1149 (T-10) . . . . . . . 35

23. Borehole geophysical logs and direction of flow under nonpumping and pumping conditions within borehole MG-1505 (Huey) ................... 37

24. Borehole geophysical logs and direction of flow under nonpumping and pumping conditions within borehole MG-1842 (T-15) ................... 39

25. Borehole-deviation log showing direction and magnitude of hole deviation from water level to the bottom of the borehole for well MG-1842 (T-15). . . . . . . . 41

26. Borehole geophysical logs for borehole MG-1843 (T-6) .................. 42

27. Borehole geophysical logs and direction of flow under nonpumping conditions within borehole MG-1844 (Fitzpatrick Container) . . . . . . . . . . . . 43

28. Borehole geophysical logs and direction of flow under nonpumping conditions within borehole MG-1845 (Fitzpatrick Container) . . . . . . . . . . . . . . . 45

29. Borehole geophysical logs and direction of flow under nonpumping conditions within borehole MG-1846 (Fitzpatrick Container) . . . . . . . . . . . . 46

30. Borehole geophysical logs for borehole MG-1897 (Clearline 3) . . . . . . . . . . . . . 47

31. Borehole geophysical logs and direction of flow determined with an 8 -inch diverter for the heatpulse flowmeter under nonpumping and pumping conditions for the upper 200 feet of the 288 -foot borehole MG-1897 (Clearline 3)

32. Graph showing correlation of single-point resistance logs in wells MG-202 (L-22), MG-1897 (Clearline 3), MG-174 (Clearline 2), and MG-1505, shown along a northwest-southeast oriented section.

33. Borehole-deviation logs showing linear deviation to the southeast in wells MG-175 (Spra-Fin 1), MG-1145 (T-14), MG-1146 (T-4), MG-1147 (T-11), and MG-1148 (T-12) in the vicinity of North Penn Area 7 Superfund site

34. Lower-hemisphere stereonet showing orientations as poles to planes of linear features interpreted from acoustic-televiewer logs for nine wells in the vicinity of North Penn Area 7 Superfund site. .

35-38. Graphs showing-

35. Depth to water above isolated interval, in isolated interval, and below isolated interval before, during, and after pumping for tests of isolated intervals zone 1 and zone 2 in well MG-174 (Clearline 2), September 17-18, 2001

36. Depth to water above isolated interval, in isolated interval, and below isolated interval before, during, and after pumping for tests of isolated intervals zone 3 and zone 4 in well MG-174 (Clearline 2), September 18-20, 2001 
37. Depth to water above isolated interval, in isolated interval, and below isolated interval before, during, and after pumping for tests of isolated intervals zone $4 \mathrm{~A}$ and zone 5 in well MG-174 (Clearline 2), September 19, 2001

38. Depth to water above isolated interval, in isolated interval, and below isolated interval before, during, and after pumping for test of isolated interval zone 6 in well $\mathrm{Mg}-174$ (Clearline 2),

September 21, 2001

39. Caliper log showing diameter and location, specific capacity, and water quality of isolated intervals for well MG-174 (Clearline 2). .

40-41. Graphs showing -

40. Depth to water above isolated interval, in isolated interval, and below isolated interval before, during, and after pumping for test of isolated intervals zone 1 and zone 2 in well MG-175 (Spra-Fin 1), April 22-23, 2002. 64

41. Depth to water above isolated interval and in isolated interval before, during, and after pumping for test of isolated interval zone 3 in well MG-175 (Spra-Fin 1), April 22, 2002. 65

42. Borehole-diameter log and location, specific capacity, and water quality of isolated intervals for MG-175 (Spra-Fin 1), North Penn Area 7 Superfund site

43-44. Graphs showing-

43. Depth to water above isolated interval, in isolated interval, and below isolated interval before, during, and after pumping for tests of isolated intervals zone 1 and zone 2 in well MG-202 (L-22), December 19-20, 2002 69

44. Depth to water above isolated interval, in isolated interval, and below isolated interval before, during, and after pumping for tests of isolated intervals zone 3 and zone 4 in well MG-202 (L-22), December 19-20, 2002

45. Borehole-diameter log and location, specific capacity, and water quality of isolated intervals for MG-202 (L-22) 73

46-47. Graphs showing-

46. Depth to water above isolated interval, in isolated interval, and below isolated interval before, during, and after pumping for tests of isolated intervals zone 1 and zone 2 in well MG-1144 (T-13), November 30, 2001

47. Depth to water above isolated interval, in isolated interval, and below isolated interval before, during, and after pumping for tests of isolated intervals zone 3 and zone 4 in well MG-1144 (T-13), November 28-29, 2001

48. Borehole-diameter log and location, specific capacity, and water quality of isolated intervals for MG-1144 (T-13)

49-50. Graphs showing-

49. Depth to water above isolated interval, in isolated interval, and below isolated interval before, during, and after pumping for test of isolated intervals zone 1 and zone 2 in well MG-1145

(T-14), December 5-6, 2001 
50. Depth to water above isolated interval, in isolated interval, and below isolated interval before, during, and after pumping for test of isolated interval zone 3 in well MG-1145 (T-14),

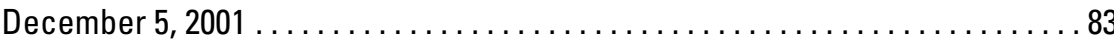

51. Borehole-diameter log and location, specific capacity, and water quality of isolated intervals for MG-1145 (T-14) . . . . . . . . . . . . . . . . . . . . . . . 84

52. Graph showing depth to water in isolated interval and in adjacent isolated interval before, during, and after pumping for tests of isolated intervals zone 1 and zone 2 in well MG-1146 (T-4), November 27-28, 2001

53. Borehole-diameter log and location, specific capacity, and water quality of isolated intervals for MG-1146 (T-4).

54. Graph showing depth to water above isolated interval, in isolated interval, and below isolated interval before, during, and after pumping for tests of isolated intervals zone 1 and zone 2 in well MG-1147 (T-11), November 15-16, 2001.......................... 90

55. Borehole-diameter log and location, specific capacity, and water quality of isolated intervals for MG-1147 (T-11) . . . . . . . . . . . . . . . . . . . . 91

56. Graph showing depth to water above isolated interval, in isolated interval, and below isolated interval before, during, and after pumping for tests of isolated intervals zone 1 and zone 2 in well MG-1842 (T-15), November 14, 2001 . 94

57. Borehole-diameter log and location, specific capacity, and water quality of isolated intervals for MG-1842 (T-15) . . 96

58-59. Graphs showing-

58. Depth to water above isolated interval, in isolated interval, and below isolated interval before, during, and after pumping for tests of isolated intervals zone 1 and zone 2 in well MG-1897 (Clearline 3), November 6-7, 2001

59. Depth to water above isolated interval, in isolated interval, and below isolated interval before, during, and after pumping for tests of isolated intervals zone 3 and zone 4 in well MG-1897 (Clearline 3), November 8-9, 2001

60. Borehole-diameter log and location, specific capacity, and water quality of isolated intervals for MG-1897 (Clearline 3)

61. Map showing location of wells with continuous water-level monitoring and pumping wells in the vicinity of North Penn Area 7 Superfund site. . 105

62-63. Graphs showing-

62. Altitude of water levels in observation wells MG-72, MG-1146, MG-174, MG-1897, and MG-147 in the vicinity of production wells MG-202 and MG-76, February-March 2002

63. Altitude of water levels in observation wells MG-175, MG-1848, MG-1849, and MG-135 in the vicinity of production wells MG-202 and MG-76, February-March 2002 108

64. Schematic cross-section in the dip direction showing altitude of open intervals in observation wells MG-175, MG-174, MG-1897, MG-72, MG-1849, MG-1848, MG-1146, MG-147, and MG-135 and production wells MG-202 and MG-76 and the approximate geologic unit boundaries in the vicinity of North Penn Area 7 Superfund site. . 
65-68. Graphs showing-

65. Drawdown in observation wells MG-72 and MG-147 in response to the start of pumping of production well MG-202 in the vicinity of North Penn Area 7 Superfund site, on March 5, 2002, at a rate of 106 gallons per minute

66. Drawdown in observation wells MG-174 and MG-1897 in response to the start of pumping of production well MG-202 in the vicinity of North Penn Area 7 Superfund site, on March 5, 2002, at a rate of 106 gallons per minute

67. Daily mean depth to water in wells MG-68, MG-72, and MG-1146, December 2000 through September 2002.

68. Instantaneous depth to water in wells MG-68 and MG-1146 and daily precipitation at the Graterford $1 \mathrm{E}$ meteorological station, March 16 through March 29, 2002, in the vicinity of North Penn Area 7 Superfund site.

69. Map showing location of two streamflow-measurement sites with quarterly measurements and two wells with continuous water-level monitoring. ...

70. Hydrographs showing altitude of water levels in wells MG-72 and MG-1146 and estimated altitudes of stream-channel bottoms nearby, December 2000 through September 2002

71-72. Graph showing-

71. Relations between base flow at streamflow-measurement site 01473900, Wissahickon Creek at Fort Washington, and water levels in wells MG-72 and MG-1146 near North Penn Area 7 Superfund site, December 2000 through September 2002

72. Daily mean water levels in long-term observation wells BK-1020 and BK-929 and in well MG-68 near North Penn Area 7 Superfund site, January 1996 through September 2002

73. Map showing estimated potentiometric surface of the fractured-sedimentaryrock aquifer determined from water levels measured in 97 drilled wells in the vicinity of North Penn Area 7 Superfund site, December 4-6, 2000

74. Schematic B-B' transect showing altitude of land surface, geometry of dipping sedimentary beds, two wells on either side of Wissahickon Creek, and possible borehole-flow directions controlled by vertical gradients determined by altitude of recharge area for confined dipping beds

\section{Tables}

1. List of wells with geophysical logs collected by U.S. Geological

Survey in the vicinity of North Penn Area 7 Superfund site, Upper Gwynedd Township, Montgomery County, Pa., December 2000 through March 2002.

2. Depths, flow rates, flow directions, and pumping rates of heatpulse-flowmeter measurements, under nonpumping and pumping conditions, for well MG-174 (Clearline 2) ... 
3. Depth and orientation of bedding, fracture, and water-bearing features interpreted from the acoustic-televiewer log and borehole video survey for well MG 174 (Clearline 2). . .

4. Depths, flow rates, flow directions, and pumping rates of heatpulse-flowmeter measurements, under nonpumping and pumping conditions, for well MG-175 (Spra-Fin 1). . .

5. Depth and orientation of bedding, fracture, and water-bearing features interpreted from the acoustic-televiewer log and borehole video survey for well MG-175 (Spra-Fin 1) ...

6. Depths, flow rates, flow directions, and pumping rates of heatpulse-flowmeter measurements, under nonpumping and pumping conditions, for well MG-202 (L-22)

7. Depths, flow rates, flow directions, and pumping rates of heatpulse-flowmeter measurements, under nonpumping and pumping conditions, for well MG-1144 (T-13)

8. Depth and orientation of bedding, fracture, and water-bearing features interpreted from the acoustic-televiewer log and borehole video survey for well MG-1144 (T-13)

9. Depths, flow rates, flow directions, and pumping rates of heatpulse-flowmeter measurements, under nonpumping and pumping conditions, for well MG-1145 (T-14) . .

10. Depth and orientation of bedding, fracture, and water-bearing features interpreted from the acoustic-televiewer log and borehole video survey for well MG-1145 (T-14)

11. Depths, flow rates, flow directions, and pumping rates of heatpulse-flowmeter measurements, under nonpumping and pumping conditions, for well MG-1146 (T-4) . .

12. Depth and orientation of bedding, fracture, and water-bearing features interpreted from the acoustic-televiewer log and borehole video survey for well MG-1146 (T-4)

13. Depths, flow rates, flow directions, and pumping rates of heatpulse-flowmeter measurements, under nonpumping and pumping conditions, for well MG-1147 (T-11)

14. Depth and orientation of bedding, fracture, and water-bearing features interpreted from the acoustic-televiewer log and borehole video survey for well MG-1147 (T-11)

15. Depths, flow rates, flow directions, and pumping rates of heatpulse-flowmeter measurements, under nonpumping and pumping conditions, for well MG-1148 (T-12)

16. Depth and orientation of bedding, fracture, and water-bearing features interpreted from the acoustic-televiewer log and borehole video survey for well MG-1148 (T-12) . . .

17. Depths, flow rates, flow directions, and pumping rates of heatpulse-flowmeter measurements, under nonpumping and pumping conditions, for well MG-1149 (T-10) .

18. Depth and orientation of bedding, fracture, and water-bearing features interpreted from the acoustic-televiewer log and borehole video survey for well MG-1149 (T-10) 
19. Depths, flow rates, flow directions, and pumping rates of heatpulse-flowmeter measurements, under nonpumping and pumping conditions, for well MG-1505 (Huey) . . . . . . . . . . . . . . . . 36

20. Depths, flow rates, flow directions, and pumping rates of heatpulse-flowmeter measurements, under nonpumping

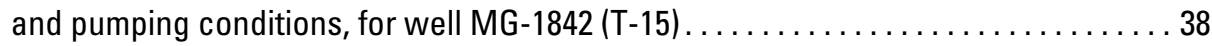

21. Depth and orientation of bedding, fracture, and water-bearing features interpreted from the acoustic-televiewer log and borehole video survey for well MG-1842 (T-15)

22. Depths, flow rates, flow directions, and pumping rates of heatpulse-flowmeter measurements, under nonpumping and pumping conditions, for well MG-1897 (Clearline 3)

23. List of wells tested using aquifer-interval-isolation methods in the vicinity of the North Penn Area 7 Superfund site, September 2001 through May 2002 54

24. Isolated intervals tested in well MG-174 (Clearline 2), September $2001 \ldots \ldots \ldots \ldots . \ldots 5$

25. Depths, water levels, and specific capacity of aquifer intervals isolated by packers for well MG-174 (Clearline 2)

26. Inorganic water-quality constituents and physical properties for samples collected from isolated intervals in well MG-174 (Clearline 2) . . . . . . . 62

27. Selected volatile organic compound concentrations in water samples from isolated intervals in well MG-174 (Clearline 2) ...............6 62

28. Isolated intervals tested in well MG-175 (Spra-Fin 1), April $2002 \ldots \ldots \ldots \ldots \ldots .63$

29. Depths, water levels, and specific capacity of aquifer intervals isolated by packers for well MG-175 (Spra-Fin 1) . . . . . . . . . . . . . . . . 65

30. Inorganic water-quality constituents and physical properties for samples collected from isolated intervals in well MG-175 (Spra-Fin 1).

31. Selected volatile organic compound concentrations in water samples from isolated intervals in well MG-175 (Spra-Fin 1) . ..............66 67

32. Isolated intervals tested in well MG-202 (L-22), December $2001 \ldots \ldots \ldots \ldots \ldots 6$

33. Depths, water levels, and specific capacity of aquifer intervals isolated by packers for well MG-202 (L-22)

34. Inorganic water-quality constituents and physical properties for samples collected from isolated intervals in well MG-202 (L-22) . . . . . . . . . . 72

35. Selected volatile organic compound concentrations in water samples from isolated intervals in well MG-202 (L-22) . . . . . . . . . . . . . . 72

36. Isolated intervals tested in well MG-1144 (T-13), November 2001 . . . . . . . . . . . . . . 74

37. Depths, water levels, and specific capacity of aquifer intervals

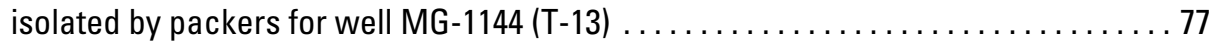

38. Inorganic water-quality constituents and physical properties for samples collected from isolated intervals in well MG-1144 (T-13) . . . . . . . . . . . 79

39. Selected volatile organic compound concentrations in water samples from isolated intervals in well MG-1144 (T-13) .................. 79

40. Isolated intervals tested in well MG-1145 (T-14), December $2001 \ldots \ldots \ldots \ldots . \ldots 80$

41. Depths, water levels, and specific capacity of aquifer intervals

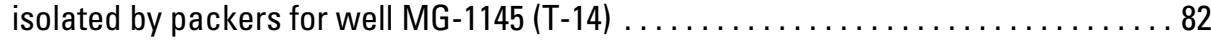

42. Inorganic water-quality constituents and physical properties for samples collected from isolated intervals in well MG-1145 (T-14) . . 
43. Selected volatile organic compound concentrations in water samples from isolated intervals in well MG-1145 (T-14) ................. 83

44. Isolated intervals tested in well MG-1146 (T-4), November $2001 \ldots \ldots \ldots \ldots \ldots . \ldots 8$

45. Depths, water levels, and specific capacity of aquifer intervals isolated by packers for well MG-1146 (T-4) $\ldots \ldots \ldots \ldots \ldots \ldots \ldots \ldots \ldots \ldots \ldots$

46. Inorganic water-quality constituents and physical properties for samples collected from isolated intervals in well MG-1146 (T-4) . . . . . . . . . . 88

47. Selected volatile organic compound concentrations in water samples from isolated intervals in well MG-1146 (T-4) . . . . . . . . . . . . . . 89

48. Isolated intervals tested in well MG-1147 (T-11), November $2001 \ldots \ldots \ldots \ldots$

49. Depths, water levels, and specific capacity of aquifer intervals

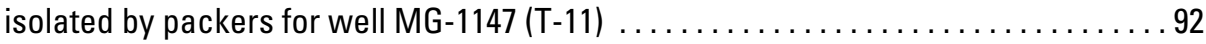

50. Inorganic water-quality constituents and physical properties for samples collected from isolated intervals in well MG-1147 (T-11) . . . . . . . . . . 92

51. Selected volatile organic compound concentrations in water samples from isolated intervals in well MG-1147 (T-11) .................. 93

52. Isolated intervals tested in well MG-1842 (T-15), November $2001 \ldots \ldots \ldots \ldots . . . .93$

53. Depths, water levels, and specific capacity of aquifer intervals isolated by packers for well MG-1842 (T-15) . . . . . . . . . . . . . . . . . . . . . 95

54. Inorganic water-quality constituents and physical properties for samples collected from isolated intervals in well MG-1842 (T-15) . ............. 95

55. Selected volatile organic compound concentrations in water samples from isolated intervals in well MG-1842 (T-15) . . . . . . . . . . . . . 97

56. Isolated intervals tested in well MG-1897 (Clearline 3), November 2001 . . . . . . . . . . . 97

57. Depths, water levels, drawdown, and specific capacity of aquifer intervals isolated by packers for well MG-1897 (Clearline 3)............... 100

58. Inorganic water-quality constituents and physical properties for samples collected from isolated intervals in well MG-1897 (Clearline 3) . ........ 102

59. Selected volatile organic compound concentrations in water samples from isolated intervals in well MG-1897 (Clearline 3)

60. Minimum and maximum specific capacity of isolated intervals and maximum concentrations of selected volatile organic compounds in water samples from isolated intervals in eight wells tested using aquifer-interval-isolation methods in the vicinity of the North Penn Area 7 Superfund site, September 2001 through May 2002

61. Schedule and rates of pumping for wells MG-202 and MG-76, February and March 2002

62. Well depth and altitude of open intervals in wells MG-202 and in wells with continuous water-level monitoring during periods of pumping well MG-202, February and March 2002, in the vicinity of North Penn Area 7 Superfund site. .

63. Well depth, casing length, well diameter, depth of water-bearing zones, and proximity to a stream for wells with continuous water-level monitoring in the vicinity of North Penn Area 7 Superfund site.

64. Annual precipitation in inches for 2000-02 and 30-year normal precipitation at four meteorological stations near North Penn Area 7 Superfund site in Bucks and Montgomery Counties, southeastern Pa. 
65. Quarterly measurements of streamflow under base-flow conditions for streamflow-measurement site 01473808, Wissahickon Creek at North Wales, Pa., and 01473809, Wissahickon Creek at Kneedler, Pa., and daily mean altitude of water levels in wells MG-72 and MG-1146,

December 2000 through September 2002.

66. Depth of wells, water levels, and heatpulse-flowmeter measurements and direction of borehole flow in wells logged near North Penn Area 7 Superfund site. ...

67. Description of selected wells and water levels in the vicinity of North Penn Area 7 Superfund site 


\section{Conversion Factors and Datum}

\begin{tabular}{|c|c|c|}
\hline Multiply & By & To obtain \\
\hline \multicolumn{3}{|c|}{ Length } \\
\hline inch (in.) & 25.4 & millimeter (mm) \\
\hline foot $(\mathrm{ft})$ & 0.3048 & meter $(\mathrm{m})$ \\
\hline mile (mi) & 1.609 & kilometer (km) \\
\hline \multicolumn{3}{|c|}{ Area } \\
\hline square mile $\left(\mathrm{mi}^{2}\right)$ & 259.0 & hectare \\
\hline square mile $\left(\mathrm{mi}^{2}\right)$ & 2.590 & square kilometer \\
\hline \multicolumn{3}{|c|}{ Volume } \\
\hline gallon (gal) & 3.785 & liter \\
\hline gallon (gal) & 0.003785 & cubic meter \\
\hline cubic foot $\left(\mathrm{ft}^{3}\right)$ & 0.02832 & cubic meter \\
\hline \multicolumn{3}{|c|}{ Flow rate } \\
\hline foot per minute (ft/min) & 0.3048 & meter per minute \\
\hline cubic foot per second $\left(\mathrm{ft}^{3} / \mathrm{s}\right)$ & 0.02832 & cubic meter per second \\
\hline gallon per minute (gal/min) & 0.06309 & liter per second \\
\hline gallon per day (gal/d) & 0.003785 & cubic meter per day $\left(\mathrm{m}^{3} / \mathrm{d}\right)$ \\
\hline million gallons per day (Mgal/d) & 0.04381 & cubic meter per second \\
\hline \multicolumn{3}{|c|}{ Specific capacity } \\
\hline gallon per minute per foot [(gal/min)/ft] & 0.207 & liter per second per meter [(L/s)/m] \\
\hline gallon per minute per foot $[(\mathrm{gal} / \mathrm{min}) / \mathrm{ft}]$ & 17.889 & meter squared per day $\left(\mathrm{m}^{2} / \mathrm{d}\right)$ \\
\hline \multicolumn{3}{|c|}{ Transmissivity } \\
\hline foot squared per day $\left(\mathrm{ft}^{2} / \mathrm{d}\right)$ & 0.0929 & meter squared per day $\left(\mathrm{m}^{2} / \mathrm{d}\right)$ \\
\hline
\end{tabular}

Temperature in degrees Celsius $\left({ }^{\circ} \mathrm{C}\right)$ may be converted to degrees Fahrenheit $\left({ }^{\circ} \mathrm{F}\right)$ as follows:

$$
{ }^{\circ} \mathrm{F}=\left(1.8 \times{ }^{\circ} \mathrm{C}\right)+32
$$

Temperature in degrees Fahrenheit $\left({ }^{\circ} \mathrm{F}\right)$ may be converted to degrees Celsius $\left({ }^{\circ} \mathrm{C}\right)$ as follows:

$$
{ }^{\circ} \mathrm{C}=\left({ }^{\circ} \mathrm{F}-32\right) / 1.8
$$

Vertical coordinate information is referenced to the National Geodetic Vertical Datum of 1929 (NGVD 29).

Altitude, as used in this report, refers to distance above the vertical datum.

*Transmissivity: The standard unit for transmissivity is cubic foot per day per square foot times foot of aquifer thickness $\left[\left(\mathrm{ft}^{3 /} \mathrm{d}\right) / \mathrm{ft}^{2}\right] \mathrm{ft}$. In this report, the mathematically reduced form, foot squared per day $\left(\mathrm{ft}^{2} / \mathrm{d}\right)$, is used for convenience.

Abbreviated water-quality units used in report: $\mathrm{mg} / \mathrm{L}$, milligrams per liter $\mu \mathrm{g} / \mathrm{L}$, micrograms per liter $\mu \mathrm{m}$, micrometer $\mu \mathrm{S} / \mathrm{cm}$, microsiemens per centimeter at 25 degrees Celsius 


\title{
Interpretation of Geophysical Logs, Aquifer Tests, and Water Levels in Wells in and Near the North Penn Area 7 Superfund Site, Upper Gwynedd Township, Montgomery County, Pennsylvania, 2000-02
}

\author{
By Lisa A. Senior, Peter J. Cinotto, Randall W. Conger, Philip H. Bird, and Karl A. Pracht
}

\begin{abstract}
Ground water in the vicinity of various industrial facilities in Upper Gwynedd Township and Lansdale Borough, Montgomery County, $\mathrm{Pa}$., is contaminated with various volatile organic compounds (VOCs). The 2-square-mile area was placed on the National Priorities List as the North Penn Area 7 Superfund site by the U.S. Environmental Protection Agency (USEPA) in 1989. The U.S. Geological Survey (USGS) conducted geophysical logging, aquifer testing, water-level monitoring, and streamflow measurements in the vicinity of North Penn Area 7 beginning autumn 2000 to assist the USEPA in developing an understanding of the hydrogeologic framework in the area as part of the USEPA Remedial Investigation.

The study area is underlain by Triassic and Jurassic-age sandstones, siltstones, and shales of the Lockatong Formation and the Brunswick Group. Regionally, these rocks strike northeast and dip to the northwest. The sequence of rocks form a fractured-sedimentary-rock aquifer that acts as a set of confined to partially confined layered aquifers of differing permeabilities. The aquifers are recharged by precipitation and discharge to streams and wells. The Wissahickon Creek headwaters are less than 1 mile northeast of the study area, and this stream flows southwest to bisect North Penn Area 7.

Ground water is pumped in the vicinity of North Penn Area 7 for industrial use and public supply.

The USGS collected geophysical logs for 16 wells that ranged in depth from 50 to 623 feet. Aquifer-interval-isolation testing was done in 9 of the 16 wells, for a total of 30 zones tested. A multiple-well aquifer test was conducted by monitoring the response of 14 wells to pumping a $600-\mathrm{ft}$ deep production well in February and March 2002. In addition, water levels were monitored continuously in three wells in the area and streamflow was measured quarterly at two sites on Wissahickon Creek from December 2000 through September 2002.
\end{abstract}

Geophysical logging identified water-bearing zones associated with high-angle fractures and bedding-plane openings throughout the depth of the boreholes. Heatpulse-flowmeter measurements under nonpumping, ambient conditions indicated that borehole flow, where detected, was in the upward direction in three of the eight wells and in the downward direction in three wells. In two wells, both upward and downward flow were measured. Heatpulse-flowmeter measurements under pumping conditions were used to identify the most productive intervals in wells. Correlation of natural-gamma-ray and single-point-resistance logs indicated that bedding in the area probably strikes about 40 degrees northeast and dips from 6 to 7 degrees northwest.

Aquifer intervals isolated by inflatable packers in wells were pumped to test productivity and to collect samples to determine chemical quality of water produced from the interval. Interval-isolation testing confirmed the presence of vertical hydraulic gradients indicated by heatpulse-flowmeter measurements. The specific capacities of isolated intervals ranged over two orders of magnitude, from 0.02 to more than 3.6 gallons per minute per foot. Intervals adjacent to isolated pumped intervals showed little response to pumping the isolated zone. The presence of vertical hydraulic gradients and lack of adjacent-interval response to pumping in isolated intervals indicate a limited degree of vertical hydraulic connection between the aquifer intervals tested. Concentrations of most VOC contaminants generally were highest in well-water samples from the shallowest isolated intervals, with some exceptions. Trichloroethylene, cis-1,2-dichloroethylene, and toluene were the most frequently detected VOCs, with maximum concentrations of greater than 340, 680, and greater than 590 micrograms per liter, respectively.

Results of the aquifer test with multiple observation wells showed that water levels in 4 of the 14 wells declined in response to pumping. The four wells that responded to pumping are either along strike or within the up-dip or down-dip projection of the producing zones of the pumped well. The spatial 
distribution of the four responding wells indicates that geologic structure has some affect over hydraulic connections in the aquifer.

Water-level monitoring in three wells from December 2000 through September 2002 shows the seasonal rise and decline of levels for the period. Water levels in two wells near Wissahickon Creek were evaluated in relation to streamflow on dates of quarterly streamflow measurements. The Wissahickon Creek was a losing stream between the two measurement sites and ground-water levels were lower than the stream channel bottom for most dates. Water levels measured in a 16square-mile area around and including North Penn Area 7 during December 2002 indicated that the ground-water level surface is relatively flat in the immediate vicinity of the North Penn Area 7 site (as compared to surrounding areas) and generally is similar to topography except in areas affected by large amounts of ground-water withdrawal.

\section{Introduction}

In 1979, ground water in the area in and around Lansdale Borough and Upper Gwynedd Township, Montgomery County, Pa., was found to be contaminated with organic chemicals, such as trichloroethylene (TCE) and tetrachloroethylene (PCE) (CH2M-Hill, Inc., 1992). The contamination was discovered by the North Penn Water Authority (NPWA), which at that time entirely relied on ground water to supply public drinking water. The U.S. Environmental Protection Agency (USEPA) investigated sources of contamination in the vicinity of Lansdale and subdivided the areas of contamination into groups of properties. The group of contaminated properties in the vicinity of production well L-22 in Upper Gwynedd Township, southeast of Lansdale and northwest of North Wales, was designated North Penn Area 7 and encompasses about $2 \mathrm{mi}^{2}$ (fig. 1). The USEPA began its investigation at North Penn Area 7 in June 1986, and the site was placed on the National Priorities List on March 31, 1989 (CH2M-Hill, Inc., 1992)

The North Penn Area 7 site includes five to eight industrial facilities reported to have used volatile organic compounds (VOCs). The commonly used VOCs were the solvents TCE, PCE, 1,1,1-trichloroethane (1,1,1-TCA), methylene chloride (MC), trichloromonofluoromethane, and dichlorofluromethane (CH2M-Hill, Inc., 1992, p. 2-1 to 2-6). Contaminants of concern detected in ground water in the vicinity of the site include TCE, PCE, 1,1,1-TCA, 1,1-dichloroethylene (1,1DCE), 1,2-dichloroethylene (1,2-DCE), cis-1,2,-DCE, trans1,2-DCE, vinyl chloride (VC), and carbon tetrachloride. Similar contamination also was detected in soils on at least six properties at the site.

Ground water in the vicinity of North Penn Area 7 has been used and continues to be used for industrial and public supply. Although some wells were abandoned in the period after contamination was discovered, other wells remain active. Abandoned wells include two contaminated production wells just south of North Penn Area 7 and five industrial production wells at the former Ford Electronics and Refrigeration Corporation (FERCO) property on the northern part of the site. As of summer 2002, ground-water pumping in the vicinity (within $0.5 \mathrm{mi}$ ) of North Penn Area 7 continues in production wells along Wissahickon Creek to the northeast of the site, at Precision Tube near the center of the site, and at the Merck \& Co., Inc., West Point facility southwest of the site.

The USEPA requested technical assistance from the U.S. Geological Survey (USGS) to provide hydrogeologic data and interpretation to be used in the Remedial Investigation/Feasibility Study (RI/FS) of the site. In autumn 2000, the USGS began to collect data as part of the technical assistance. The data will be used to describe the ground-water system and to provide a basis for the simulation of ground-water flow. The ground-water-flow simulation will be used to evaluate the effect of pumping on the directions of ground-water flow and contamination transport. The first phase of work, completed in September 2002, included geophysical logging of available wells, aquifer tests of isolated intervals in available wells, and water-level mapping and monitoring.

\section{Purpose and Scope}

This report presents and provides preliminary interpretation of geophysical-log, aquifer-test, and water-level data collected in the vicinity of the North Penn Area 7 Superfund site, Montgomery County, Pa., during the period from October 2000 through August 2002 as part of the technical assistance to USEPA for a RI/FS. This period (October 2000 through August 2002) is the first phase of data collection in a multiphase project. Boreholes logged, tested, and monitored during this period were available production and monitor wells.

Geophysical logs for 16 boreholes are described and used to identify (1) water-bearing zones and relative productivity of these zones, (2) direction and magnitude of borehole flow under nonpumping and pumping conditions, and (3) lithologic intervals that can be used for stratigraphic correlation. Naturalgamma and single-point-resistance logs are correlated, where possible, to estimate orientation of bedding. Results of singlewell aquifer interval-isolation tests (in which intervals are isolated by packers) are presented for nine wells and include, for each isolated interval, the measured potentiometric heads, calculated specific capacity, estimated transmissivity, and water quality of sampled water $(\mathrm{pH}$, specific conductance, temperature, alkalinity, selected inorganic constituents, and selected VOCs). Results of one multi-well aquifer test (one pumping well and multiple observation wells) are presented and include spatial distribution of drawdown and estimated aquifer transmissivity determined from an analytical solution. Streamflow measurements under base-flow conditions are discussed in relation to ground-water levels to gain insight into groundwater/surface-water relations. Water levels in wells also are discussed in relation to regional ground-water flow and a conceptual model of the ground-water system. 
$75^{\circ} 17^{\prime} 30^{\prime \prime}$

$75^{\circ} 16^{\prime} 15^{\prime \prime}$

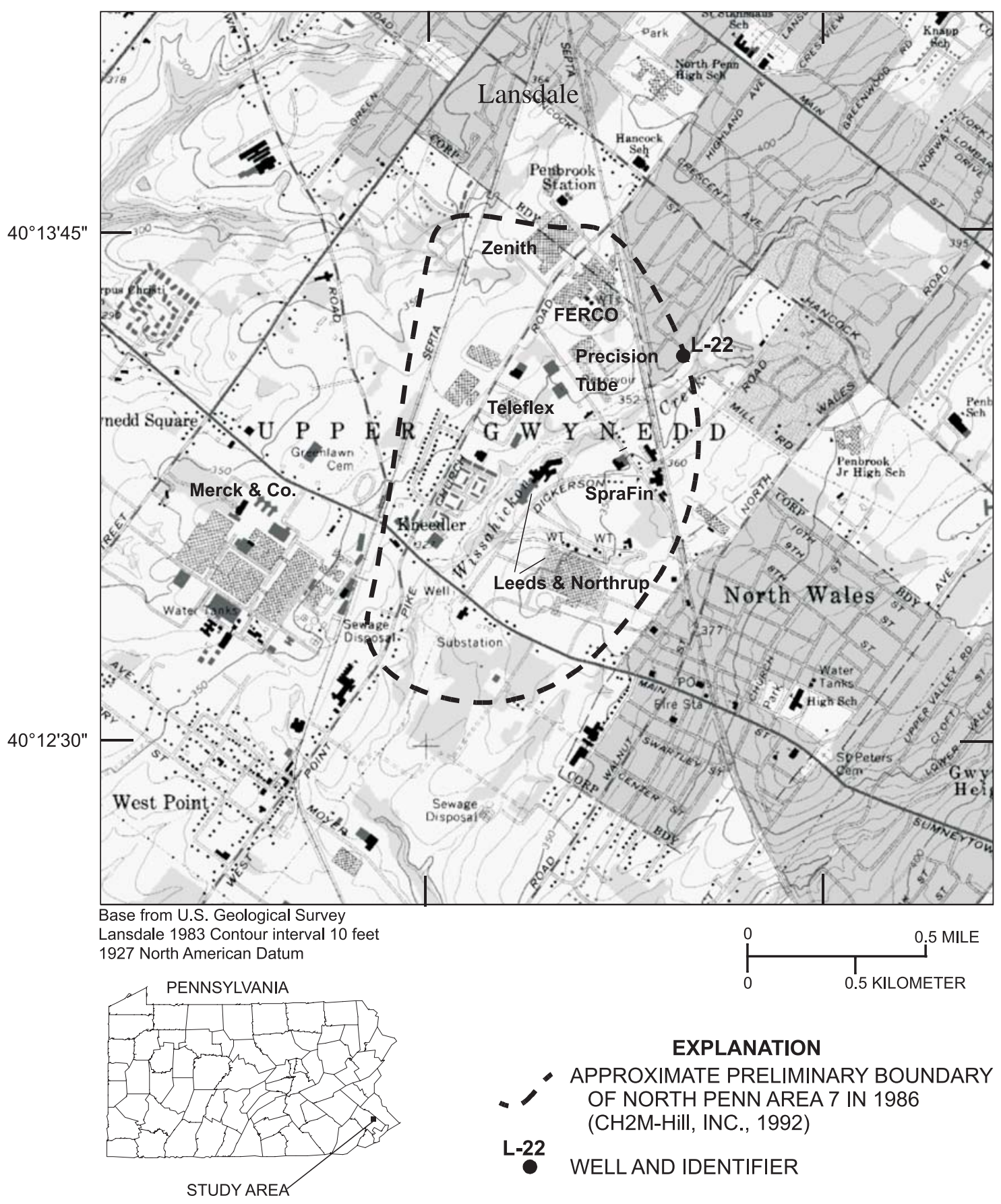

Figure 1. Location of North Penn Area 7 Superfund site, Upper Gwynedd Township, Montgomery County, Pa. 
The information generated during the first phase of the investigation will be used to help describe the hydrogeology and provide a foundation for subsequent data collection and the simulation and understanding of directions of ground-water flow and contamination migration in the study area.

\section{Physical and Hydrogeologic Setting}

The study area in and near Lansdale and Upper Gwynedd Township is in the Gettysburg-Newark Lowlands section of the Piedmont Physiographic Province (Sevon, 2000) (fig. 2). The area is underlain by sedimentary rocks of the Lockatong Formation and lower beds of the Brunswick Group of the Newark Supergroup (Lyttle and Epstein, 1987) (fig. 3). Sediments of the Newark Supergroup were deposited in a rift basin during the Triassic age (260 million years ago). Following deposition, sediments in the Newark Basin were buried, lithified, tilted, and faulted. The Lockatong Formation commonly is relatively resistant to erosion and tends to form ridges that rise above flat or rolling topography underlain by rocks of the Brunswick Group. The North Penn Area 7 site is on relatively flat terrain (as compared to the surrounding area) bisected by the Wissahickon Creek. The western boundary of the site is approximately along the railroad tracks just west of Church Road (fig. 1). Church Road lies near the surface-water divide between the Towamencin Creek Basin to the west and the Wissahickon Creek Basin to the east.

The Lockatong Formation consists of detrital sequences (cycles) of gray to black calcareous shale and siltstone, with some pyrite, and chemical sequences (cycles) of gray to black dolomitic siltstone and marlstone with lenses of pyritic limestone, overlain by massive gray to red siltstone with analcime (Lyttle and Epstein, 1987). Interbeds of reddish-brown, sandy siltstone have been mapped in the Lockatong Formation south of Lansdale (Lyttle and Epstein, 1987). Contacts between the Lockatong Formation and the overlying Brunswick Group are conformable and gradational, and the two formations may interfinger (Lyttle and Epstein, 1987). The lower beds of the Brunswick Group consist predominantly of homogeneous,

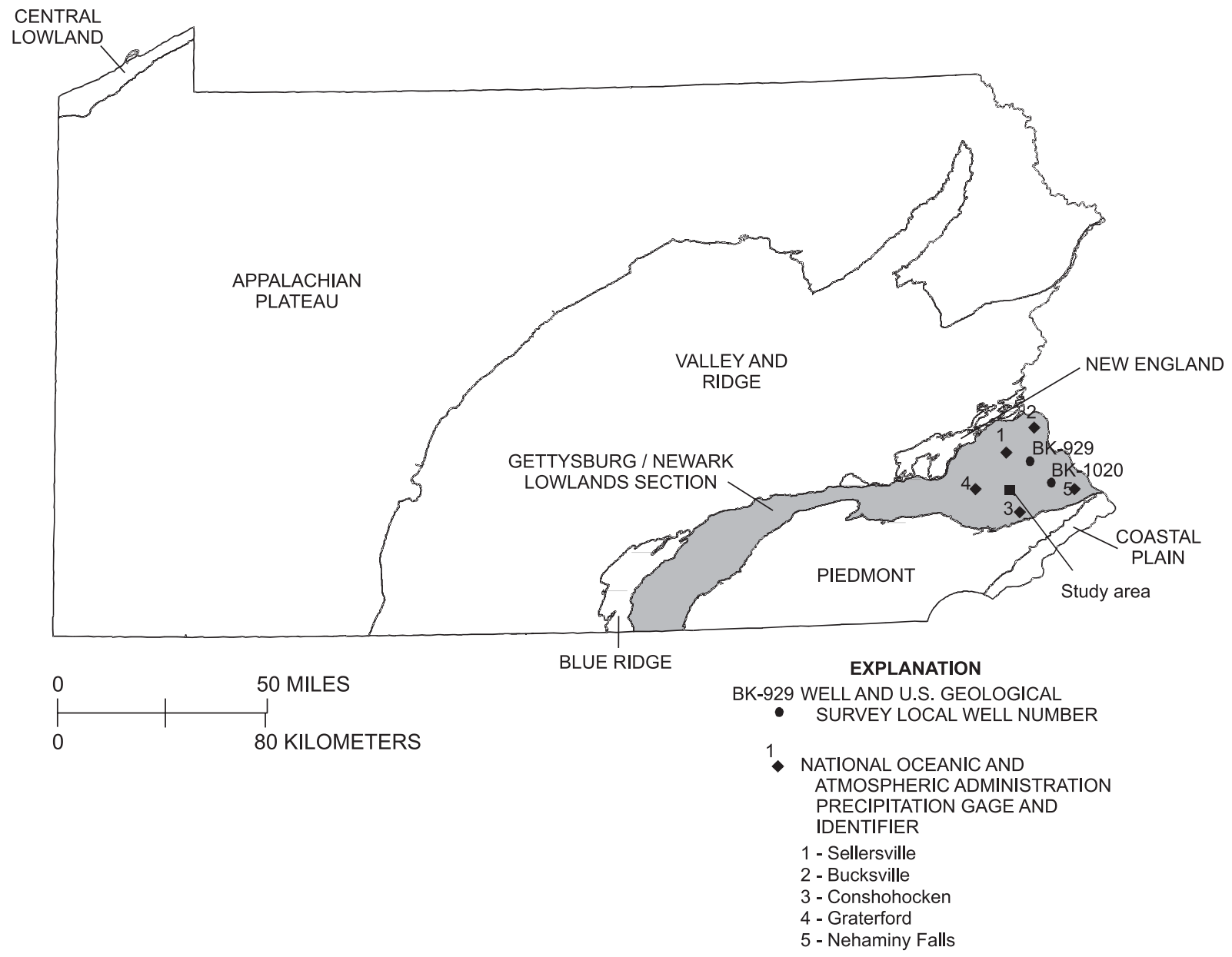

Figure 2. Physiographic provinces in Pennsylvania and location of selected wells and precipitation gages in southeastern Pennsylvania in the vicinity of North Penn Area 7 Superfund site, Upper Gwynedd Township, Montgomery County, $\mathrm{Pa}$. 


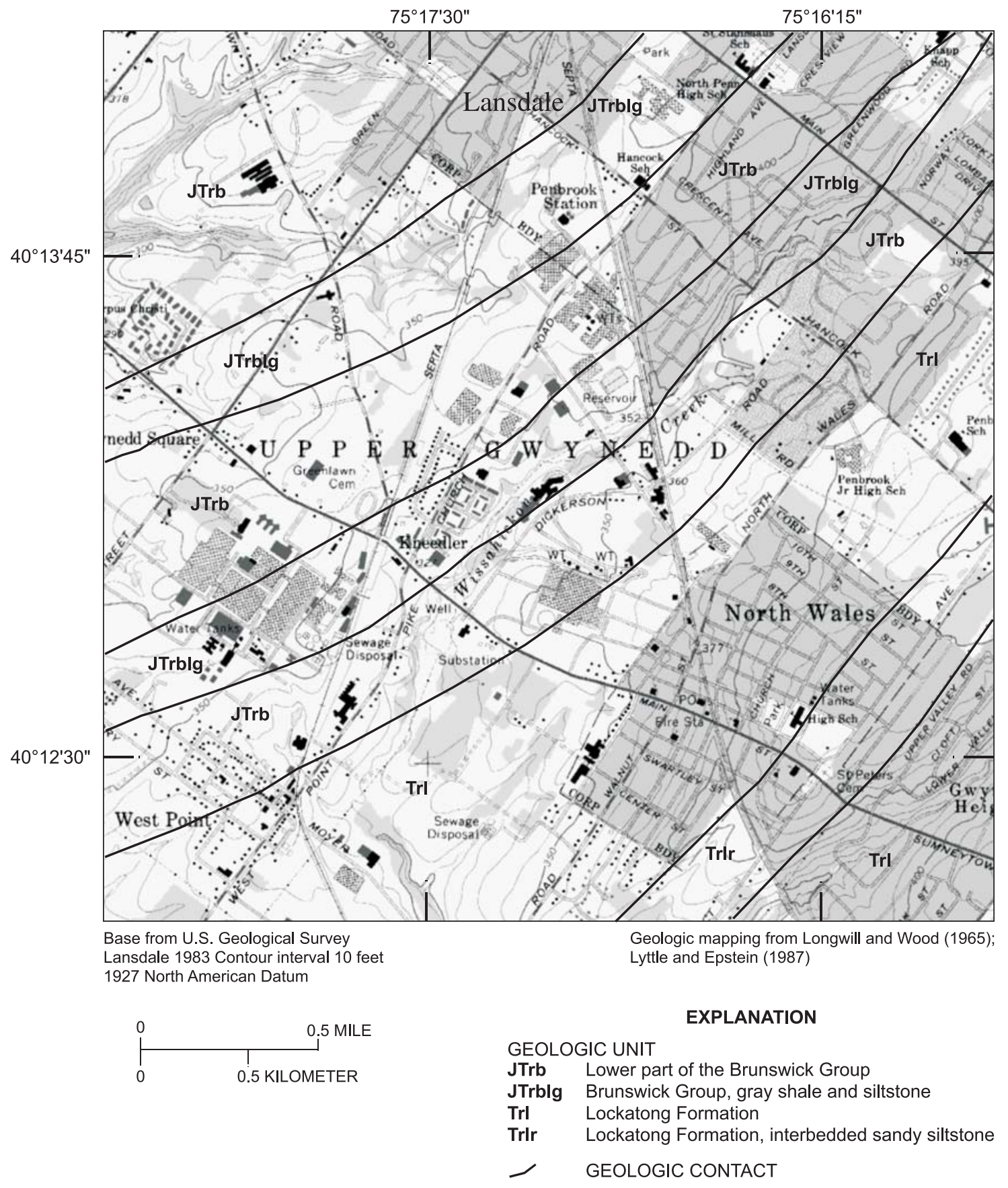

Figure 3. Bedrock geology in the vicinity of North Penn Area 7 Superfund site, Upper Gwynedd Township, Montgomery County, Pa. 
soft, red to reddish-brown and gray to greenish-gray mudstones and clay- and mud-shales, with some fine-grained sandstones and siltstones. Bedding is irregular and wavy. Some beds are micaceous. Interbedded silt-shales and siltstones are moderately well sorted. Mudcracks, ripple marks, crossbeds, and worm burrows are common in all the beds. The Brunswick Group rocks contain detrital cycles of medium- to dark-gray and olive- to greenish-gray, thin-bedded and evenly bedded shale and siltstone, similar to the underlying Lockatong Formation.

Bedding in the Newark Basin regionally strikes northeast and dips to the northwest. The regional homoclinal dip has been cut by normal and strike-slip faults and warped by transverse folds (Schlische, 1992). Many faults with small displacements have not been mapped. Locally, the beds of the Brunswick Group and Lockatong Formation generally strike northeast and dip shallowly to the northwest in the vicinity of the North Penn Area 7 site, with a gradual shift in strike from northeast in central Lansdale to east-northeast in the area south of Lansdale near North Wales (fig. 3) (Longwill and Wood, 1965). Thin shale marker beds in the Brunswick Group identified by elevated natural-gamma activity (above background levels) on geophysical logs can be correlated over distances of $1,000 \mathrm{ft}$ or more. High natural-gamma activity typically is associated with thin gray or black shale beds. Correlation of natural-gamma activity in logs collected by USGS in and near Lansdale show these shale beds strike 48 to 60 degrees NE., and dip 6 to 30 degrees NW., with an average dip of about 11 degrees (Conger, 1999).

Ground water in the rocks underlying the North Penn Area 7 site originates from infiltration of local precipitation. After infiltrating through soil and saprolite (extensively weathered rock), ground water moves through near-vertical and bedding-plane fractures in the shale and siltstone bedrock. Depth to competent bedrock commonly is less than $20 \mathrm{ft}$ below land surface. The soil, saprolite, and individual beds of the sedimentary bedrock form a layered aquifer, with varying degrees of hydraulic connection between the layers. Hydraulic properties of the soil, saprolite, and fracture networks in individual beds of the underlying sedimentary bedrock differ. Primary porosity, permeability, and storage in the Triassic-age sedimentary bedrock is low.

Ground water in the shallowest part of the fractured-sedimentary-rock aquifer may be under unconfined (water-table) or partially confined conditions; the unconfined part of the aquifer probably is thin and is difficult to delineate. In some areas, perched water is present at shallow depths (less than $50 \mathrm{ft}$ ). Ground water in the deeper part of the aquifer generally is confined or partially confined, resulting in artesian conditions.

Shallow and deep ground-water-flow systems may be present at the site. Generally, shallow and deep ground water flows in a direction similar to the topographic gradient. Water from the shallow system likely discharges locally to streams and leaks downward to the deep ground-water-flow system. Deep ground water discharges to streams and to pumping wells; the natural direction of shallow to deep ground-water flow is altered by pumping. Pumping from deep water-bearing zones may induce downward flow from shallow zones. Cones of depression caused by pumping have been observed to extend preferentially along strike of bedding planes or in the direction of fracture orientation in the Triassic-age sedimentary rocks of the Brunswick Group and the Lockatong Formation, (Longwill and Wood, 1965).

The conceptual model of the ground-water system in the study area consists of dipping, layered fractured rocks with ground-water flow occurring within partings developed primarily along bedding planes (Senior and Goode, 1999). Vertical fractures generally do not cut extensively across beds but may provide local routes of ground-water flow or leakage between beds.

\section{Well-Identification System}

The USGS local well number is used in this report as the primary well identification. The USGS local well number consists of a two-letter county-abbreviation prefix followed by a sequentially assigned number. The prefix MG denotes a well in Montgomery County. The USGS also assigns each well a unique 15-digit site number based on latitude and longitude in degrees, minutes, and seconds and a 2-digit sequence number. Some wells have other names or numbers assigned by owners or used in the CH2M-Hill report (CH2M-Hill, Inc., 1992). A complete listing of USGS local well and site numbers and owner-assigned well numbers is given in table 67 at the end of the report.

\section{Previous Investigations}

Ground-water studies in the Lansdale Borough and Upper Gwynedd Township area have been prompted by concern about limited ground-water availability during periods of drought, by discovery of contaminated drinking water from production wells, and by interest in commercial and industrial uses of the ground water. Rima (1955), Longwill and Wood (1965), and Newport (1971) provide well-characteristic and ground-water-quality data and description of ground-water resources in Montgomery County, Pa., including the Lansdale and Upper Gwynedd Township area. Longwill and Wood (1965) compiled a geologic map, which in the Lansdale area was based almost entirely on unpublished manuscripts by Dean B. McLaughlin of the Pennsylvania Geological Survey. Lyttle and Epstein (1987) compiled a geologic map of the Newark $1 \times 2$ degrees quadrangle that updates and revises the geologic nomenclature for the area. Biesecker and others (1968) described the water resources of the Schuylkill River Basin, which drains part of the study area.

Investigations of ground-water contamination after 1979 by USEPA and others are summarized in a report to the USEPA by CH2M-Hill, Inc. (1992). An evaluation of ground water pumpage at the Merck \& Co., Inc., West Point plant was 
done by Geraghty \& Miller, Inc. (1993). Investigations of ground-water quality at the FERCO facility in North Penn Area 7 were described by Converse Consultants East (1994). Sources of ground-water contamination in the nearby North Penn Area 6 site are identified additionally in another report to the USEPA by Black \& Veatch Waste Science, Inc. (1994). A map of ground-water levels in the vicinity of Lansdale that includes ground-water levels within North Penn Area 7 was done by Senior and others (1998). Goode and Senior (1998) present a review of aquifer tests done in the Lansdale area from 1980 through 1995, including tests done in industrial-supply wells at manufacturing facilities in and near North Penn Area 7. Senior and Goode (1999) describe the ground-water system and simulation of ground-water flow for the North Penn Area 6 site and vicinity, including an area in and near North Penn Area 7.

\section{Geophysical Logs}

Geophysical logs provide information on the location and orientation of fractures, water-bearing zones (producing and receiving zones), intervals and quantification of vertical borehole flow, lithology, and well construction. Geophysical logs conducted in wells at North Penn Area 7 include caliper, natural-gamma, single-point-resistance, fluid-temperature, heatpulse flowmeter, borehole television, and acoustic-televiewer logs.

Caliper logs provide a continuous record of average borehole diameter, which is related to drill-bit size, fractures, and drilling technique. These logs are used to identify fractures and possible water-producing or receiving zones and to correct other geophysical logs for changes in borehole diameter. Correlation of caliper logs with fluid-resistivity and fluid-temperature logs is used to identify fractures, water-producing zones, and water-receiving zones.

The natural-gamma log measures the varying amounts of gamma radiation (photons) naturally emitted from all rocks. The most common emitters of natural-gamma radiation are uranium-238, thorium-232, their daughter elements, and potassium-40. Commonly, these radioactive elements are concentrated in clays by adsorption, precipitation, and ion exchange. Fine-grained sediments, such as shale or siltstone, commonly emit more gamma radiation than coarse-grained sediments, such as sandstone. The natural-gamma log records radiation in fluid-filled, dry, cased, or uncased parts of the borehole. Casing, however, reduces the gamma signal. The gamma log can be used to help determine lithology and to correlate geologic units between wells (Keys, 1990).

The single-point-resistance log records the electrical resistance of the geologic formation between the probe in a water-filled borehole below casing and an electrical ground at land surface. Generally, electrical resistance increases with formation grain size and decreases with borehole diameter, presence of water-bearing fractures, and increasing dissolved- solids concentration of borehole water. The single-point-resistance log, like the natural-gamma log, can be used to help determine lithology and to correlate geologic units between wells. Elevated single-point-resistance measurements in a borehole may be associated with sandstone units. The singlepoint-resistance and natural-gamma logs commonly have an inverse relation in sedimentary rocks, reflecting the different properties of shales and sandstones. In addition to indicating lithology, the single-point-resistance log may help identify water-bearing zones (Keys, 1990).

Fluid-temperature logs provide a continuous record of the temperature of water in the borehole. Temperature logs are used to identify water-bearing zones and to determine zones of vertical flow within the borehole. Intervals of borehole flow commonly are characterized by little or no temperature gradient (Williams and Conger, 1990).

The heatpulse flowmeter is used to determine the direction and rate of borehole-fluid movement. The instrument operates by heating a small sheet of water between two vertically separated thermistors (sensitive heat sensors). A measurement of direction and rate of borehole flow is computed when a peak temperature is recorded by one of the thermistors. The range of flow measurement is about $0.01-1.5 \mathrm{gal} / \mathrm{min}$ in a 2 - to 10-in.-diameter borehole (Conger, 1996). Some heatpulse-flowmeter measurements may be affected by (1) poor seal integrity between the borehole wall and the flowmeter or (2) contributions of water from storage within the borehole under pumping conditions. If the seal between the flowmeter and the borehole wall is not complete, some water can bypass the flowmeter, resulting in measurements of flow that are less than the actual rate. Although the heatpulse flowmeter is a calibrated probe, the data commonly are used as a relative indicator to identify water-producing or receiving zones. Instrumentation used to measure pumping rates during flowmeter logging from December 2000 through March 2002 was not accurate for rates that were less than $1 \mathrm{gal} / \mathrm{min}$.

Borehole television logs record a video image of the borehole walls. These logs are conducted by lowering a waterproof camera down the borehole and recording the image on videotape. Features, such as casing length, fractures, or lithologic changes, usually can be observed on the logs.

The borehole acoustic-televiewer log is a magnetically oriented, 360 degree image of the acoustic reflection of the borehole wall. The acoustic televiewer is an ultrasonic imaging tool operating at a frequency of about 1 megahertz that scans the borehole wall with an acoustic beam generated by a pulsed piezoelectric source rotating at about 3 revolutions per second as the tool is moved up the borehole at about $3 \mathrm{ft} / \mathrm{min}$. The tool can be used in 2- to 8-in.-diameter liquid-filled uncased boreholes. Digital images are recorded by a computer and the log is represented in two dimensions by splitting the image vertically along the north axis and unrolling it flat. A smooth and hard borehole wall produces a uniform reflection pattern. The intersection of a fracture with the borehole wall scatters the acoustic waves, producing dark, linear features. Because the image is magnetically oriented, the attitude (dip and strike) of the frac- 
ture plane can be determined. Some lithologic features, such as bedding, may also result in a change in the acoustic reflection. The interpretation of acoustic-televiewer logs involves judgement of what may or may not be a planar feature, and, therefore, some uncertainty is associated with the identification of features and their orientation.

The borehole-deviation log is a continuous record of the borehole's deviation from the vertical and is recorded by the acoustic-televiewer probe to automatically correct apparent feature orientations to true strike and dip but may be generated as a separate $\log$. In addition to drilling techniques, various characteristics of the subsurface environment may cause borehole deviation, including fractures, voids, and lithologic changes. In some formations, such as shales, dipping bed structure may form a general control of deviation. It has been noted that when bedding dips less than 45 degrees, the drill bit tends to migrate up-dip (Wilson, 1976) and, in some cases, to penetrate these beds at an angle normal (perpendicular) to the bedding plane (Brown and others, 1981). Greater flexibility in the drill string (drill bit and added rods) with increasing length (borehole depth) allows the drilling angle to more closely approach an angle normal to the bedding planes; therefore, deeper boreholes will have an angle of deviation closer to normal than shallower boreholes, especially in the deepest sections of the borehole.

\section{Interpretation of Individual Well Logs}

Geophysical logging was conducted in 16 wells in and near the North Penn Area 7 site from December 2000 through March 2002. The types of logs and well-construction data for the logged wells are listed in table 1 . All digital data for logs and borehole video tapes are archived and available from the USGS Pennsylvania Water Science Center. The locations of the 16 wells and 6 wells logged earlier by USGS (MG-72 and MG-76) and by consultants to FERCO, Converse Consultants East, Inc., (MG-90, MG-135, MG-147, and MG-151) are shown in figure 4 . The log suite for each of the 16 wells logged by USGS for this study is discussed individually and is followed by a discussion of multiple logs, including log correlation and interpretation of borehole-deviation and acoustic-televiewer data. Discussion of individual logs includes description of well construction and identification of (1) water-bearing zones and relative productivity of water-bearing zones, where possible, (2) direction and magnitude of borehole flow under nonpumping and pumping conditions, and (3) lithologic intervals that can be used for stratigraphic correlation. Use of the terms major and minor for water-bearing zones indicates magnitude relative to all zones of the borehole.

Table 1. List of wells with geophysical logs collected by U.S. Geological Survey in the vicinity of North Penn Area 7 Superfund site, Upper Gwynedd Township, Montgomery County, Pa., December 2000 through March 2002.

[Locations of wells are shown on figure 4. --, no data; Abbreviations for type of logs: A, acoustic-televiewer; B, borehole-video; C, caliper; G, natural-gamma; $\mathrm{R}$, single-point-resistance; $\mathrm{T}$, fluid-temperature; $\mathrm{V}$, borehole-flow; $\mathrm{W}$, borehole-deviation]

\begin{tabular}{|c|c|c|c|c|c|c|c|}
\hline $\begin{array}{c}\text { U.S. } \\
\text { Geological } \\
\text { Survey } \\
\text { local } \\
\text { well number }\end{array}$ & $\begin{array}{l}\text { Owner's } \\
\text { well name } \\
\text { or number }\end{array}$ & $\begin{array}{l}\text { Logged } \\
\text { well depth } \\
\text { (feet) }\end{array}$ & $\begin{array}{c}\text { Logged } \\
\text { casing } \\
\text { length } \\
\text { (feet) }\end{array}$ & $\begin{array}{l}\text { Casing } \\
\text { diameter } \\
\text { (inches) }\end{array}$ & $\begin{array}{c}\text { Date } \\
\text { logged }^{1}\end{array}$ & $\begin{array}{l}\text { Depth to water } \\
\text { on date of } \\
\text { logging } \\
\text { (feet below } \\
\text { land surface) }\end{array}$ & $\begin{array}{l}\text { Types } \\
\text { of logs }\end{array}$ \\
\hline MG-174 & Clearline 2 & 160 & 73 & 6 & $12 / 12 / 00$ & 34.93 & $\mathrm{~A}, \mathrm{~B}, \mathrm{C}, \mathrm{G}, \mathrm{R}, \mathrm{T}, \mathrm{V}, \mathrm{W}$ \\
\hline MG-175 & Spra-Fin 1 & 103 & 14 & 6 & $3 / 29 / 02$ & 38.83 & $\mathrm{~A}, \mathrm{~B}, \mathrm{C}, \mathrm{G}, \mathrm{R}, \mathrm{T}, \mathrm{V}, \mathrm{W}$ \\
\hline MG-202 & L-22 & 623 & 40 & 12 & $12 / 13 / 01$ & 53.32 & $\mathrm{~B}, \mathrm{C}, \mathrm{G}, \mathrm{R}, \mathrm{T}, \mathrm{V}$ \\
\hline MG-1144 & $\mathrm{T}-13$ & 84 & 18.5 & 6 & $10 / 12 / 01$ & 31.35 & $\mathrm{~A}, \mathrm{~B}, \mathrm{C}, \mathrm{G}, \mathrm{R}, \mathrm{T}, \mathrm{V}, \mathrm{W}$ \\
\hline MG-1145 & $\mathrm{T}-14$ & 83 & 19 & 6 & $10 / 12 / 01$ & 26.80 & $\mathrm{~A}, \mathrm{~B}, \mathrm{C}, \mathrm{G}, \mathrm{R}, \mathrm{T}, \mathrm{V}, \mathrm{W}$ \\
\hline MG-1146 & $\mathrm{T}-4$ & 84.5 & 18.5 & 6 & $10 / 1 / 01$ & 37.33 & $\mathrm{~A}, \mathrm{~B}, \mathrm{C}, \mathrm{G}, \mathrm{R}, \mathrm{T}, \mathrm{V}, \mathrm{W}$ \\
\hline MG-1147 & $\mathrm{T}-11$ & 83.5 & 18 & 6 & $8 / 30 / 01$ & 39.19 & $\mathrm{~A}, \mathrm{~B}, \mathrm{C}, \mathrm{G}, \mathrm{R}, \mathrm{T}, \mathrm{V}, \mathrm{W}$ \\
\hline MG-1148 & $\mathrm{T}-12$ & 84 & 19 & 6 & $10 / 11 / 01$ & 52.48 & $\mathrm{~A}, \mathrm{~B}, \mathrm{C}, \mathrm{G}, \mathrm{R}, \mathrm{T}, \mathrm{V}, \mathrm{W}$ \\
\hline MG-1149 & $\mathrm{T}-10$ & 84 & 18.5 & 6 & $10 / 11 / 01$ & 51.13 & $\mathrm{~A}, \mathrm{~B}, \mathrm{C}, \mathrm{G}, \mathrm{R}, \mathrm{T}, \mathrm{V}, \mathrm{W}$ \\
\hline MG-1505 & -- & 83.2 & 16 & 6 & $10 / 26 / 01$ & 25.94 & $\mathrm{C}, \mathrm{G}, \mathrm{R}, \mathrm{T}, \mathrm{V}$ \\
\hline MG-1842 & $\mathrm{T}-15$ & 86 & 18 & 6 & $10 / 10 / 01$ & 41.18 & $\mathrm{~A}, \mathrm{~B}, \mathrm{C}, \mathrm{G}, \mathrm{R}, \mathrm{T}, \mathrm{V}, \mathrm{W}$ \\
\hline MG-1843 & $\mathrm{T}-6$ & 37.5 & 18 & 6 & $10 / 11 / 01$ & 30.30 & $\mathrm{~B}, \mathrm{C}, \mathrm{G}, \mathrm{R}, \mathrm{T}, \mathrm{V}$ \\
\hline MG-1844 & -- & 51.2 & 15 & 6 & $10 / 30 / 01$ & 43.98 & $\mathrm{~B}, \mathrm{C}, \mathrm{G}, \mathrm{R}, \mathrm{T}, \mathrm{V}$ \\
\hline MG-1845 & -- & 54.6 & 19 & 6 & $10 / 30 / 01$ & 44.92 & $\mathrm{~B}, \mathrm{C}, \mathrm{G}, \mathrm{R}, \mathrm{T}, \mathrm{V}$ \\
\hline MG-1846 & -- & 55.9 & 21 & 6 & $10 / 30 / 01$ & 46.19 & $\mathrm{~B}, \mathrm{C}, \mathrm{G}, \mathrm{R}, \mathrm{T}, \mathrm{V}$ \\
\hline MG-1897 & Clearline 3 & 288 & 44 & 10 & $10 / 24 / 01$ & 24.28 & $\mathrm{~B}, \mathrm{C}, \mathrm{G}, \mathrm{R}, \mathrm{T}, \mathrm{V}$ \\
\hline
\end{tabular}

\footnotetext{
${ }^{1}$ Date when logging began, except for acoustic-televiewer and television logs.
} 


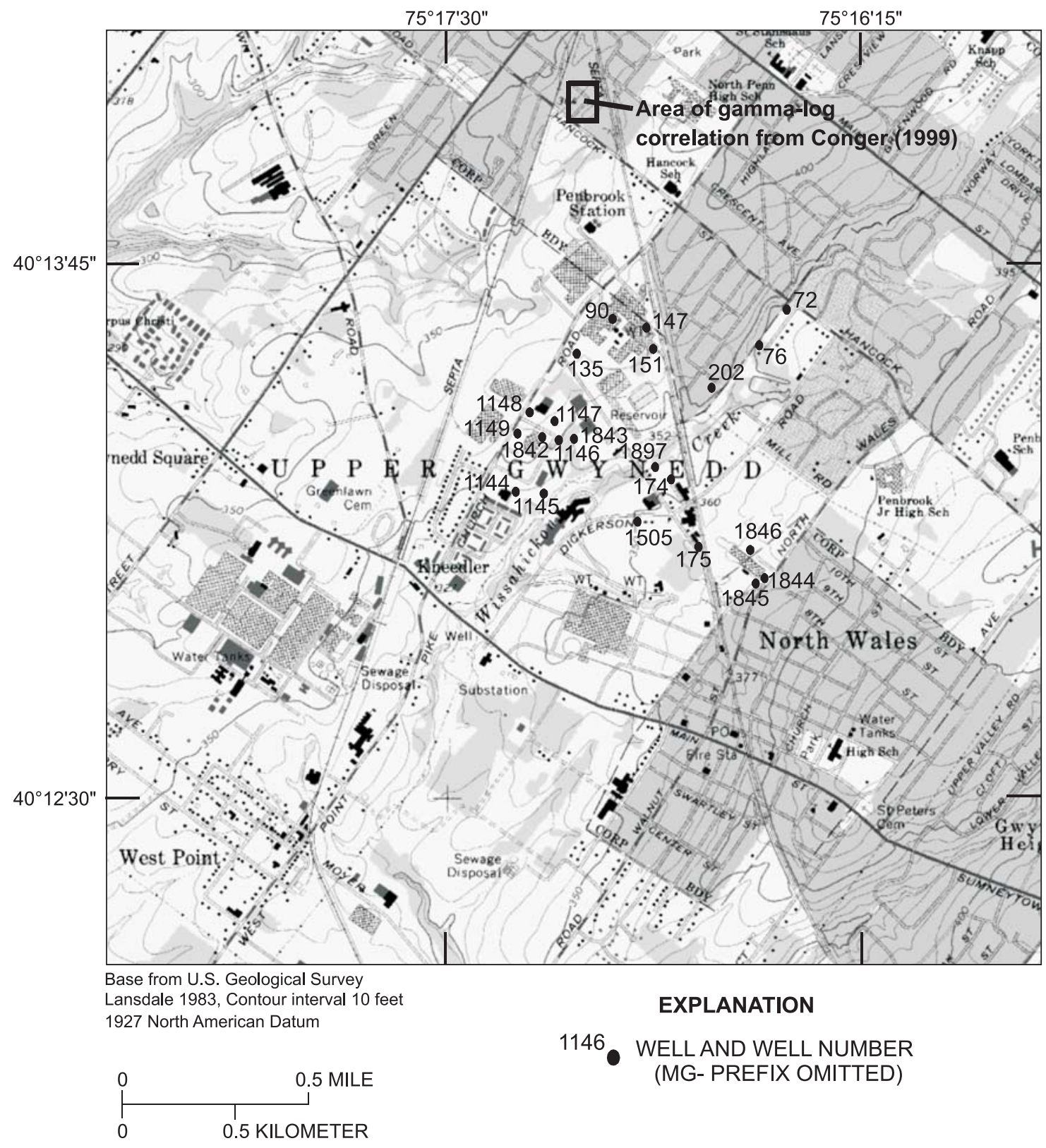

Figure 4. Location of wells with geophysical logs in the vicinity of North Penn Area 7 Superfund site, Upper Gwynedd Township, Montgomery County, Pa. 


\section{Well MG-174 (Clearline 2)}

The caliper log shows the total depth of the borehole is $160 \mathrm{ft}$ and it is cased with 6-in.-diameter steel casing to about $73 \mathrm{ft}$ below land surface (bls) (fig. 5). The open borehole is about 6 in. in diameter to a depth of $110 \mathrm{ft}$ bls and 8 in. in diameter or larger below that depth. There are numerous major and minor fractures throughout the borehole; the interval between 130 and $150 \mathrm{ft}$ bls is especially fractured as indicated with the caliper and other logs. The borehole video shows possible water-bearing near-vertical fractures and openings at 74-75, $87,89,109,112,124$, and $126 \mathrm{ft}$ bls, with especially long nearvertical fractures and openings from $129 \mathrm{ft}$ bls to the bottom of the borehole corresponding to the openings shown on the caliper log. At $141 \mathrm{ft}$ bls, a cavernous opening was noted.

The natural-gamma log (fig. 5) shows slightly elevated counts at 90-100 and 120-128 ft bls that may be associated with shale units. The single-point-resistance log shows zones of elevated resistance at about 76-86 and 101-110 ft bls that may indicate sandstone units. Lithologic changes were observed on the borehole video at 94, 99, 108, and $122 \mathrm{ft}$ bls.

The static water level at the time of logging was $34.93 \mathrm{ft}$ bls. The fluid-temperature log (fig. 5) shows fluid temperature decreases slightly with depth and shows minor inflections at about 96,106, and $138 \mathrm{ft}$ bls. The relatively straight temperature profile is consistent with vertical flow in the borehole. Under nonpumping conditions, the heatpulse flowmeter measured upward flow at 83,96,106, and $122 \mathrm{ft} \mathrm{bls}$ and no flow at 60 and $140 \mathrm{ft}$ bls (table 2). These measurements (table 2) indicate that, under nonpumping conditions, water probably enters the borehole in the intervals between 83 and 96, 106 and 122, and 122 and $140 \mathrm{ft}$ bls and exits the borehole in the intervals between 73 and 83 and 96 and $106 \mathrm{ft}$ bls. For measurements of flow under pumping conditions, a submersible pump was placed at $55 \mathrm{ft}$ bls and the well was pumped at an initial rate of $1.74 \mathrm{gal} / \mathrm{min}$ for 10 minutes, a rate of $1.57 \mathrm{gal} / \mathrm{min}$ for 4 minutes, and then a constant rate about $1.01 \mathrm{gal} / \mathrm{min}$. Heatpulse-flowmeter measurements made under pumping conditions indicate that the interval between 73 and $83 \mathrm{ft}$ bls is the most productive. Possible water-bearing fractures in that interval are shown at 76-77 ft bls on the caliper log near the top of an interval of elevated single-point-resistance readings that are indicative of sandstone units. After $40 \mathrm{~min}$ utes of pumping at about $1 \mathrm{gal} / \mathrm{min}$, the water level declined $1.35 \mathrm{ft}$ to $36.28 \mathrm{ft}$ bls.

Table 2. Depths, flow rates, flow directions, and pumping rates of heatpulse-flowmeter measurements, under nonpumping and pumping conditions, for well MG-174 (Clearline 2), North Penn Area 7 Superfund site, Upper Gwynedd Township, Montgomery County, Pa.

[ft bls, feet below land surface; gal/min, gallons per minute; NF, no flow measured; --, no data]

\begin{tabular}{cccccccc}
\hline $\begin{array}{c}\text { Depth } \\
\text { of } \\
\text { measurement } \\
\text { (ft bls) }\end{array}$ & \multicolumn{2}{c}{$\begin{array}{c}\text { Nonpumping } \\
\text { conditions }\end{array}$} & & \multicolumn{3}{c}{ Pumping conditions } \\
\cline { 2 - 3 } \cline { 6 - 7 } & $\begin{array}{c}\text { Flow } \\
\text { rate } \\
\text { (gal/min) }\end{array}$ & $\begin{array}{c}\text { Flow } \\
\text { direction }\end{array}$ & & $\begin{array}{c}\text { Flow } \\
\text { rate } \\
\text { (gal/min) }\end{array}$ & $\begin{array}{c}\text { Flow } \\
\text { direction }\end{array}$ & $\begin{array}{c}\text { Pumping } \\
\text { rate } \\
\text { (gal/min) }\end{array}$ \\
\hline 60 & NF & NF & & -- & -- & -- \\
65 & -- & -- & & 0.60 & up & 1.06 \\
83 & 0.5 & up & & .55 & up & 1.01 \\
93 & -- & -- & & .33 & up & 1.03 \\
96 & .3 & up & & - & -- & -- \\
106 & .7 & up & & .73 & up & 1.03 \\
122 & .2 & up & & .18 & up & 1.03 \\
140 & NF & NF & -- & -- & -- \\
\hline
\end{tabular}

Interpretation of the acoustic-televiewer log (table 3 ) in conjunction with the borehole video and other logs shows water-bearing fractures at about 76, 86, 88, 99, 109, 112, and 129-140 ft bls intersect the borehole at angles from 28 to 68 degrees. Most water-bearing fractures appear to be highangle features. Many of the probable water-bearing fractures strike northeast and dip to the southeast, and some of these fractures occur adjacent to fractures that strike northwest. A possible water-bearing zone may be associated with a lowangle feature observed on the borevideo at $99 \mathrm{ft}$ bls. Beddingplane features at 100 to $103 \mathrm{ft}$ bls intersect the borehole at relatively shallow angles (19 to 28 degrees) and strike northeast to almost due north, dipping southeast to southwest (table 3). During drilling, the borehole deviated from vertical about 1.5 $\mathrm{ft}$ to the north, as determined from the deviation log (fig. 6). 

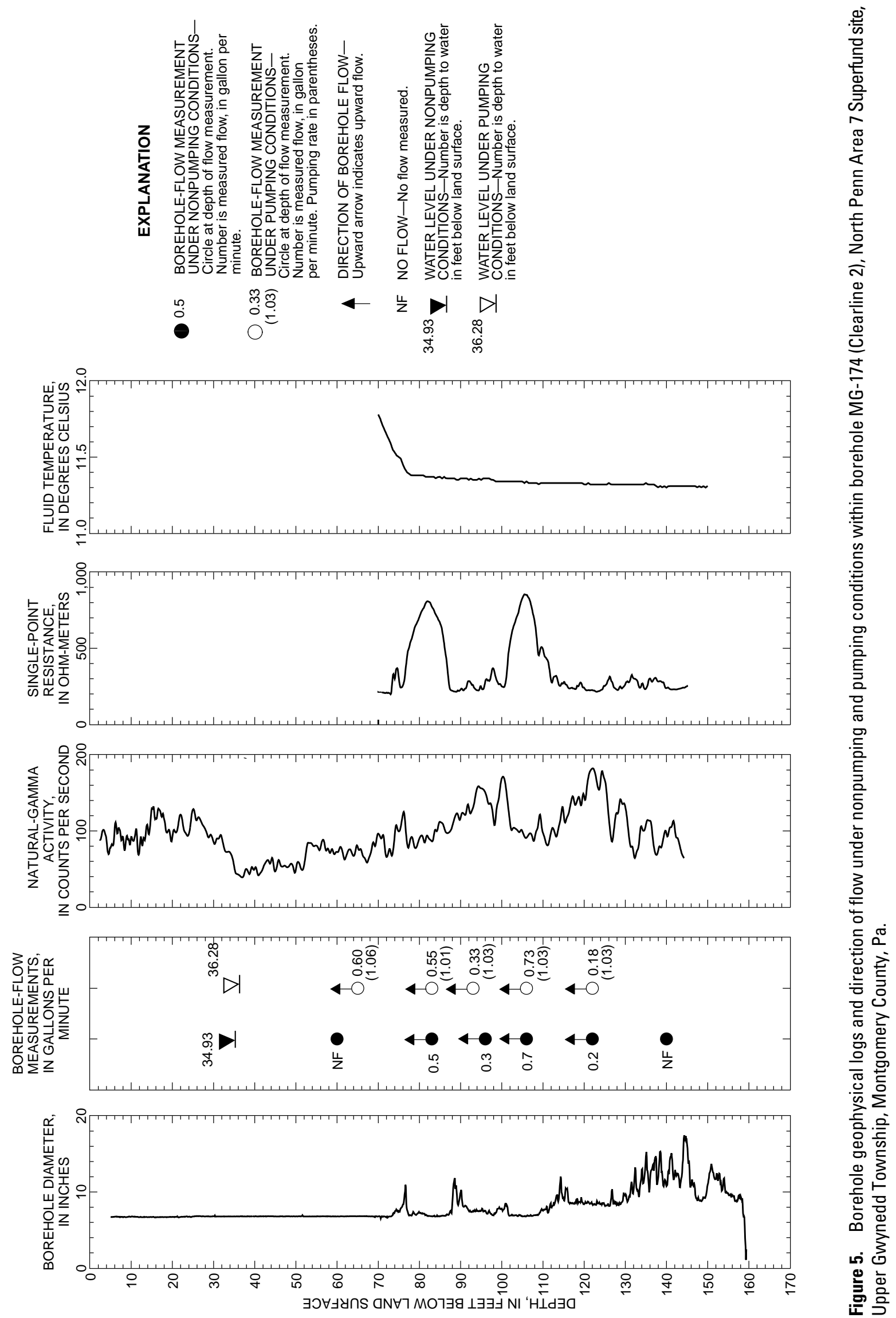
Table 3. Depth and orientation of bedding, fracture, and water-bearing features interpreted from the acousticteleviewer log and borehole video survey for well MG 174 (Clearline-2), North Penn Area 7 Superfund site, Upper Gwynedd Township, Montgomery County, Pa.

[ft bls, feet below land surface; Orientations: N, north; E, east; S; south, W; west; --, not determined; Feature type abbreviations: B, bedding plane; F, fracture; FT, fracture trace (mineral-filled fracture plane); WB, water-bearing opening; ?, indicates uncertainty in feature type; water-bearing features are shown in bold typeface]

\begin{tabular}{|c|c|c|c|c|}
\hline \multirow{2}{*}{$\begin{array}{l}\text { Feature } \\
\text { depth } \\
\text { (ft bls) }\end{array}$} & \multicolumn{2}{|c|}{ Feature orientation } & \multirow{2}{*}{$\begin{array}{c}\text { Feature } \\
\text { type }\end{array}$} & \multirow[b]{2}{*}{ Borehole video survey observation } \\
\hline & $\begin{array}{c}\text { Strike } \\
\text { (degrees) }\end{array}$ & $\begin{array}{c}\text { Dip } \\
\text { (degrees) }\end{array}$ & & \\
\hline 76.1 & N $51 \mathbf{E}$ & $57 \mathrm{SE}$ & F/WB? & High-angle fracture, open 74-75 ft bls \\
\hline 76.5 & N 62 W & $28 \mathrm{NE}$ & F/WB? & \\
\hline 85.7 & N 50 E & $68 \mathrm{NW}$ & F/WB? & Open, high-angle fracture at $87 \mathrm{ft}$ bls \\
\hline 88.0 & N 70 W & $62 \mathrm{SW}$ & F/WB? & Open, high-angle fracture at $89 \mathrm{ft}$ bls \\
\hline 99 & -- & -- & B/WB? & Low-angle fracture \\
\hline 100.8 & $\mathrm{~N} 46 \mathrm{E}$ & $19 \mathrm{SE}$ & FT & \\
\hline 101.2 & N $80 \mathrm{E}$ & $22 \mathrm{SE}$ & FT & \\
\hline 102.7 & N $3 \mathrm{~W}$ & $28 \mathrm{SW}$ & FT & \\
\hline 109.4 & N 12 E & $56 \mathrm{SE}$ & F/WB & High-angle fracture at $109 \mathrm{ft}$ bls \\
\hline 109.7 & N 64 E & $52 \mathrm{SE}$ & F/WB & \\
\hline 110.5 & N $63 \mathrm{E}$ & $63 \mathrm{SE}$ & $\mathrm{F}$ & \\
\hline 112 & -- & -- & F/WB? & High-angle fracture, open $112-115 \mathrm{ft}$ bls \\
\hline 124 & -- & -- & $\mathrm{F}$ & Moderate-angle fracture, possibly WB \\
\hline 126 & -- & -- & $\mathrm{F}$ & Moderate-angle fracture, possibly WB \\
\hline 129 & -- & -- & F/WB & High-angle fractures, open 129-157 ft bls (bottom of hole) \\
\hline 141 & -- & -- & $\mathrm{F}$ & Cavernous opening \\
\hline
\end{tabular}

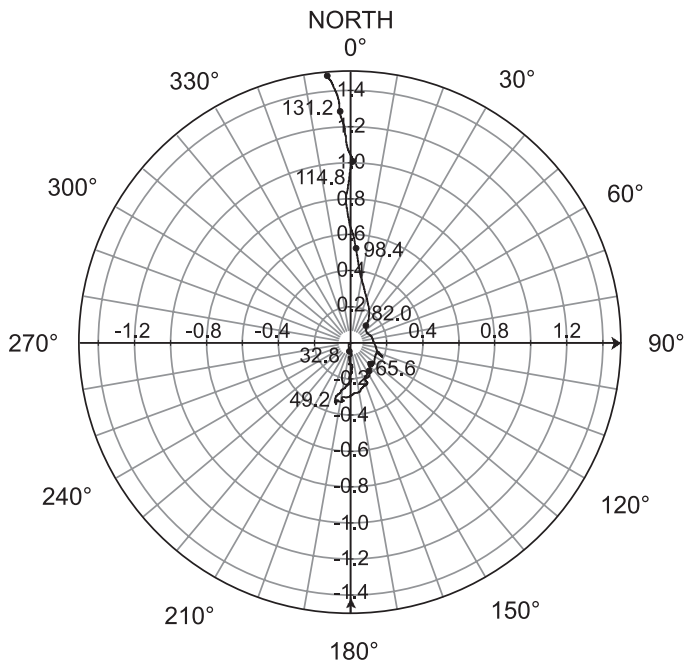

EXPLANATION

DIRECTION AND MAGNITUDE OF

DEVIATION -- Direction shown by trace of line relative to azimuth in degrees from true north.

Magnitude, in feet, shown by location of trace relative to concentric circles

114.8 - MEASUREMENT OF BOREHOLE DEPTH, IN FEET
Figure 6. Borehole-deviation log showing direction (in degrees) and magnitude (in feet) of hole deviation from water level to the bottom of the borehole for well MG-174 (Clearline-2), North Penn Area 7 Superfund site, Upper Gwynedd Township, Montgomery County, $\mathrm{Pa}$. 


\section{Well MG-175(Spra-Fin 1)}

The caliper log shows that the total depth of the borehole is $103 \mathrm{ft}$ and it is cased with 6-in.-diameter steel casing to about $14 \mathrm{ft}$ bls (fig. 7). The open borehole is 6 in. in diameter, and there are about five fractures near the top and bottom sections of the borehole. The largest fractures are in the intervals between 82 and 83 and 96 and $103 \mathrm{ft}$ bls. The borehole video shows near-horizontal fractures and openings at 41, 79-80, 9697, and $102 \mathrm{ft}$ bls; the latter three intervals correspond with the openings shown on the caliper log.

The natural-gamma and single-point-resistance logs have an inverse relation. For example, the natural-gamma log shows slightly depressed counts at $61-63,70-74$, and $78-82 \mathrm{ft}$ bls that correspond to slightly elevated single-point-resistance readings at the same zones and may be associated with sandstone units (fig. 7). The natural-gamma and single-point-resistance logs indicate that lithology probably alternates between shales and sandstones.

The static water level at the time of logging was $38.83 \mathrm{ft}$ bls. The fluid-temperature log shows that temperature decreases slightly with depth below $60 \mathrm{ft}$ bls and shows minor inflections at about 80 and $96 \mathrm{ft}$ bls. The sloping temperature profile is consistent with no vertical flow in the borehole. Under nonpumping conditions, the heatpulse flowmeter measured no detectable flow at 50, 70, and $90 \mathrm{ft}$ bls (table 4). For heatpulse-flowmeter measurements of flow under pumping conditions, a submersible pump was placed at $50 \mathrm{ft}$ bls and the well was pumped at rates of 1.0 to $1.09 \mathrm{gal} / \mathrm{min}$. These measurements (table 4) indicate that, under pumping conditions, water enters the borehole in the intervals between 70 and 90 and 90 and $103 \mathrm{ft}$ bls. These producing zones correspond to observed fractures at about 80-82 and 96-99, and 101$102 \mathrm{ft}$ bls on the caliper log. These fractures are at similar depths of elevated single-point-resistance readings that possibly indicate sandstone units. Heatpulse-flowmeter measurements made under pumping conditions indicate that these two zones produce similar amounts of water. After 20 minutes of pumping at about $1 \mathrm{gal} / \mathrm{min}$, the water level declined $0.29 \mathrm{ft}$ to $39.12 \mathrm{ft}$ bls.

Table 4. Depths, flow rates, flow directions, and pumping rates of heatpulse-flowmeter measurements, under nonpumping and pumping conditions, for well MG-175 (Spra-Fin 1), North Penn Area 7 Superfund site, Upper Gwynedd Township, Montgomery County, Pa.

[ft bls, feet below land surface; gal/min, gallons per minute; NF, no flow measured; --, no data]

\begin{tabular}{cccccccc}
\hline $\begin{array}{c}\text { Depth } \\
\text { of } \\
\begin{array}{c}\text { measurement } \\
\text { (ft bls) }\end{array}\end{array}$ & \multicolumn{2}{c}{$\begin{array}{c}\text { Nonpumping } \\
\text { conditions }\end{array}$} & & \multicolumn{3}{c}{ Pumping conditions } \\
\cline { 7 - 8 } \cline { 5 - 7 } & $\begin{array}{c}\text { Flow } \\
\text { rate } \\
\text { (gal/min) }\end{array}$ & $\begin{array}{c}\text { Flow } \\
\text { direction }\end{array}$ & & $\begin{array}{c}\text { Flow } \\
\text { rate } \\
\text { (gal/min) }\end{array}$ & $\begin{array}{c}\text { Flow } \\
\text { direction }\end{array}$ & $\begin{array}{c}\text { Pumping } \\
\text { rate } \\
\text { (gal/min) }\end{array}$ \\
\hline 50 & $\mathrm{NF}$ & $\mathrm{NF}$ & -- & -- & -- \\
60 & -- & -- & & 0.96 & up & 1.00 \\
70 & $\mathrm{NF}$ & $\mathrm{NF}$ & & 1.12 & up & 1.08 \\
90 & $\mathrm{NF}$ & $\mathrm{NF}$ & & .50 & up & 1.09 \\
\hline
\end{tabular}

Interpretation of the acoustic-televiewer log (table 5) indicates that possible water-bearing fractures intersect the borehole at about 81 and $99 \mathrm{ft}$ bls at relatively low angles (from 17 to 20 degrees), in agreement with the borehole video and other logs. These fractures strike northeast and dip southeast, as do various bedding-plane features. Other beddingplane features also intersect the borehole at relatively shallow angles (from 9 to 40 degrees) and appear to strike both northeast, dipping southeast, and northwest, dipping southwest. A few high-angle fractures (at about 72, 75, and $91 \mathrm{ft}$ bls) strike northeast and dip from 80 to 86 degrees to northwest or southeast. During drilling, the borehole deviated from vertical about $1.6 \mathrm{ft}$ to the southeast, as determined from the deviation $\log$ (fig. 8). 

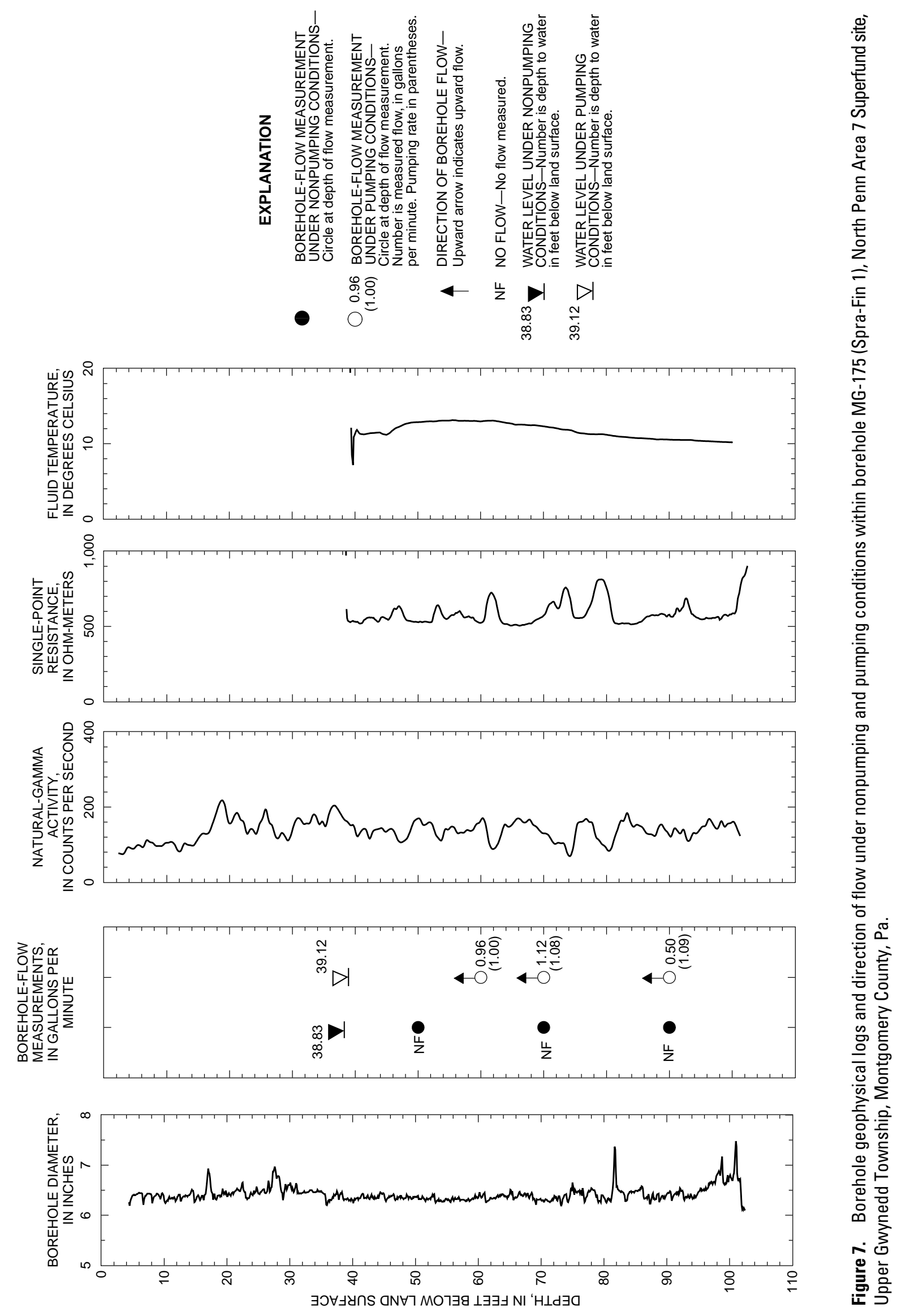
Table 5. Depth and orientation of bedding, fracture, and water-bearing features interpreted from the acousticteleviewer log and borehole video survey for well MG-175 (Spra-Fin1), North Penn Area 7 Superfund site, Upper Gwynedd Township, Montgomery County, Pa.

[ft bls, feet below land surface; Orientations: N, north; E, east; S; south, W; west; --, not determined; Feature type abbreviations: B, bedding plane; F, fracture; WB, water-bearing opening; ?, indicates uncertainty in feature type; water-bearing features are shown in bold typeface]

\begin{tabular}{|c|c|c|c|c|}
\hline \multirow{2}{*}{$\begin{array}{c}\text { Feature } \\
\text { depth } \\
\text { (ft bls) }\end{array}$} & \multicolumn{2}{|c|}{ Feature orientation } & \multirow{2}{*}{$\begin{array}{l}\text { Feature } \\
\text { type }\end{array}$} & \multirow[b]{2}{*}{ Borehole video survey observation } \\
\hline & $\begin{array}{c}\text { Strike } \\
\text { (degrees) }\end{array}$ & $\begin{array}{c}\text { Dip } \\
\text { (degrees) }\end{array}$ & & \\
\hline 40.0 & N $38 \mathrm{E}$ & $13 \mathrm{SE}$ & $\mathrm{B}$ & \\
\hline 41.1 & N 42 E & $40 \mathrm{SE}$ & B/WB & Low-angle fracture \\
\hline 41.8 & $\mathrm{~N} 46 \mathrm{~W}$ & $23 \mathrm{SW}$ & B & \\
\hline 44.5 & N $22 \mathrm{E}$ & $11 \mathrm{SE}$ & $\mathrm{B}$ & \\
\hline 45.9 & N $27 \mathrm{~W}$ & $13 \mathrm{SW}$ & B & \\
\hline 46.0 & N 14 E & $22 \mathrm{SE}$ & B & \\
\hline 49.9 & N $64 \mathrm{~W}$ & $40 \mathrm{SW}$ & B & \\
\hline 52.8 & N $87 \mathrm{~W}$ & $24 \mathrm{SW}$ & B & \\
\hline 55.0 & N $66 \mathrm{~W}$ & $26 \mathrm{SW}$ & B & \\
\hline 60.2 & $\mathrm{~N} 80 \mathrm{E}$ & $9 \mathrm{SE}$ & B & \\
\hline 61.1 & N $1 \mathrm{E}$ & $29 \mathrm{SE}$ & $\mathrm{B}$ & \\
\hline 63.0 & N $77 \mathrm{E}$ & $32 \mathrm{SE}$ & $\mathrm{B}$ & \\
\hline 64.0 & N 52 E & $17 \mathrm{SE}$ & $\mathrm{B}$ & \\
\hline 65.5 & N $56 \mathrm{~W}$ & $21 \mathrm{NE}$ & $\mathrm{B}$ & Low-angle fracture \\
\hline 66.6 & N $85 \mathrm{E}$ & $15 \mathrm{SE}$ & $\mathrm{B}$ & Low-angle fracture \\
\hline 67.5 & N $11 \mathrm{E}$ & $12 \mathrm{NW}$ & $\mathrm{B}$ & \\
\hline 68.6 & N $15 \mathrm{~W}$ & $19 \mathrm{NE}$ & $\mathrm{B}$ & \\
\hline 71.7 & N 63 E & $84 \mathrm{NW}$ & $\mathrm{F}$ & High-angle fracture \\
\hline 72.8 & N 54 E & $9 \mathrm{SE}$ & $\mathrm{B}$ & \\
\hline 75.0 & N 55 E & $21 \mathrm{SE}$ & $\mathrm{B}$ & \\
\hline 75.1 & N $63 \mathrm{E}$ & $80 \mathrm{NW}$ & $\mathrm{F}$ & High-angle fracture \\
\hline 77.3 & N $79 \mathrm{E}$ & $11 \mathrm{SE}$ & $\mathrm{B}$ & \\
\hline 81.3 & N 83 E & 16SE & B/WB & Open, low-angle fractures 79-80 ft bls \\
\hline 82.5 & N 15 E & $32 \mathrm{SE}$ & B & \\
\hline 86.2 & N $31 \mathrm{E}$ & $34 \mathrm{SE}$ & B & \\
\hline 90.4 & N $31 \mathrm{E}$ & 19SE & B & \\
\hline 90.6 & N $65 \mathrm{E}$ & $10 \mathrm{SE}$ & B & \\
\hline 90.9 & N 54 E & $86 \mathrm{SE}$ & $\mathrm{F}$ & \\
\hline 91.2 & N 66 E & $13 \mathrm{SE}$ & B & \\
\hline 91.5 & N $68 \mathrm{E}$ & $12 \mathrm{SE}$ & B & \\
\hline 92.2 & $\mathrm{~N} 49 \mathrm{E}$ & $12 \mathrm{SE}$ & B & \\
\hline 96 & -- & -- & F/WB & High- and low-angle fractures 96-97 ft bls \\
\hline 98.6 & N 86 W & 17SW & F/WB & $\begin{array}{l}\text { High-angle fracture } 97-98 \mathrm{ft} \text { bls; high- and low-angle } \\
\text { fractures } 99-100 \mathrm{ft} \text { bls }\end{array}$ \\
\hline 102.5 & -- & -- & F/WB? & Open \\
\hline
\end{tabular}




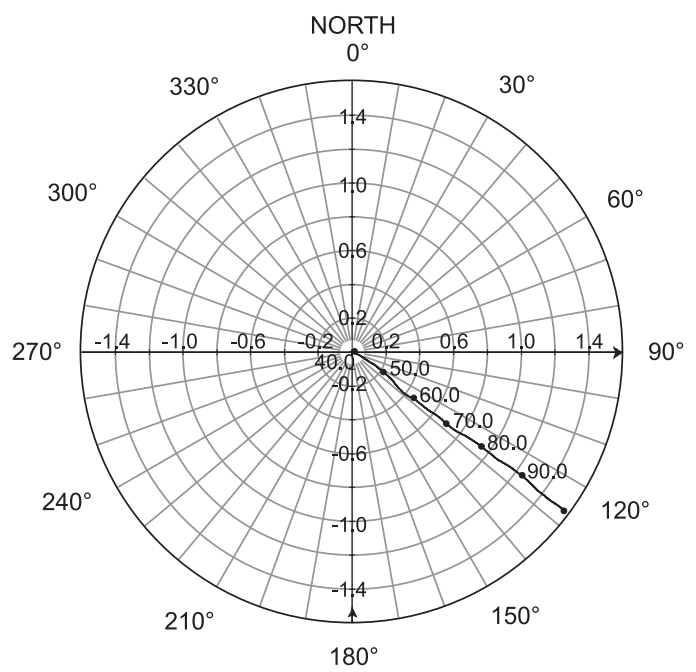

EXPLANATION

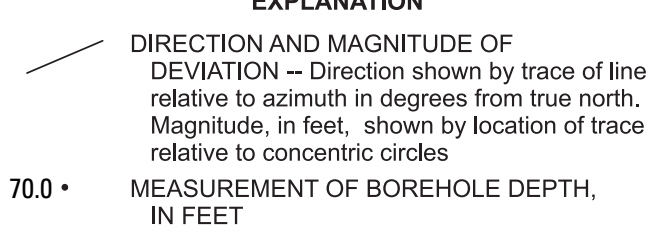

Figure 8. Borehole-deviation log showing direction (in degrees) and magnitude (in feet) of hole deviation from water level to the bottom of the borehole for well MG-175 (Spra-Fin 1), North Penn Area 7 Superfund site, Upper Gwynedd Township, Montgomery County, Pa.

\section{Well MG-202(L-22)}

The caliper log shows that the total depth of the borehole is $623 \mathrm{ft}$ and it is cased with 12-in.-diameter steel casing to about $40 \mathrm{ft}$ bls (fig. 9). The open borehole is $12 \mathrm{in}$. in diameter to a depth of $322 \mathrm{ft}$ bls and $10 \mathrm{in}$. in diameter from 322 to $623 \mathrm{ft}$ bls. There are numerous major and minor fractures throughout borehole, and the interval between 40 and $120 \mathrm{ft}$ bls appears highly fractured. The borehole video shows possible water-bearing near-vertical fractures and openings at $49,53,110,159,405$, and $426 \mathrm{ft}$ bls and near-horizontal fractures at 220 and $227 \mathrm{ft}$ bls.

The natural-gamma log (fig. 9) shows elevated counts at about 443 and $575 \mathrm{ft}$ bls that probably are associated with shale units and might be used for stratigraphic correlation. The single-point-resistance log shows that 10 - to 20 -ft thick intervals of elevated resistance are present regularly throughout the borehole and are likely associated with sandstone units. The apparent general increase in resistance with depth below $250 \mathrm{ft}$ bls is either caused by real changes in lithology (sandier units) or a decrease in dissolved-solids concentration with depth. Although the fluid-resistivity log was not conducted because of equipment malfunction, the increase in temperature with depth below $250 \mathrm{ft}$ bls, discussed below, indicates low borehole circulation and commonly is associated with increases in dissolved-solids concentration.

The static water level at the time of logging was $53.32 \mathrm{ft}$ bls. The fluid-temperature log (fig. 9) shows that temperature increases slightly with depth from static water level at $53 \mathrm{ft}$ bls to $160 \mathrm{ft}$ bls, changes little from 160 to $220 \mathrm{ft}$ bls, and gradually increases again below $220 \mathrm{ft}$ bls. Sharp inflections in the temperature log are apparent at 160 and $225 \mathrm{ft}$ bls and a broader inflection is shown at about $300 \mathrm{ft}$ bls. The relatively straight temperature profiles associated with the intervals 53160 and 160-220 ft bls are consistent with vertical flow in the borehole. The gradual increase in fluid temperature below $300 \mathrm{ft}$ bls probably is because of the geothermal gradient (heating with depth) and indicates little to no borehole flow.

Heatpulse-flowmeter measurements were made at depths of less than $300 \mathrm{ft}$ bls (fig. 10) because the temperature profile indicated little to no borehole flow below that depth (fig. 9). Under nonpumping conditions, the heatpulse flowmeter measured downward flow at 62 and $90 \mathrm{ft}$ bls; probable downward flow at rates greater than detection at 142, 174, and $212 \mathrm{ft}$ bls; no detectable flow at 223.5 and $262 \mathrm{ft}$ bls; and slight upward flow at $234 \mathrm{ft}$ bls (fig. 10; table 6). These measurements 

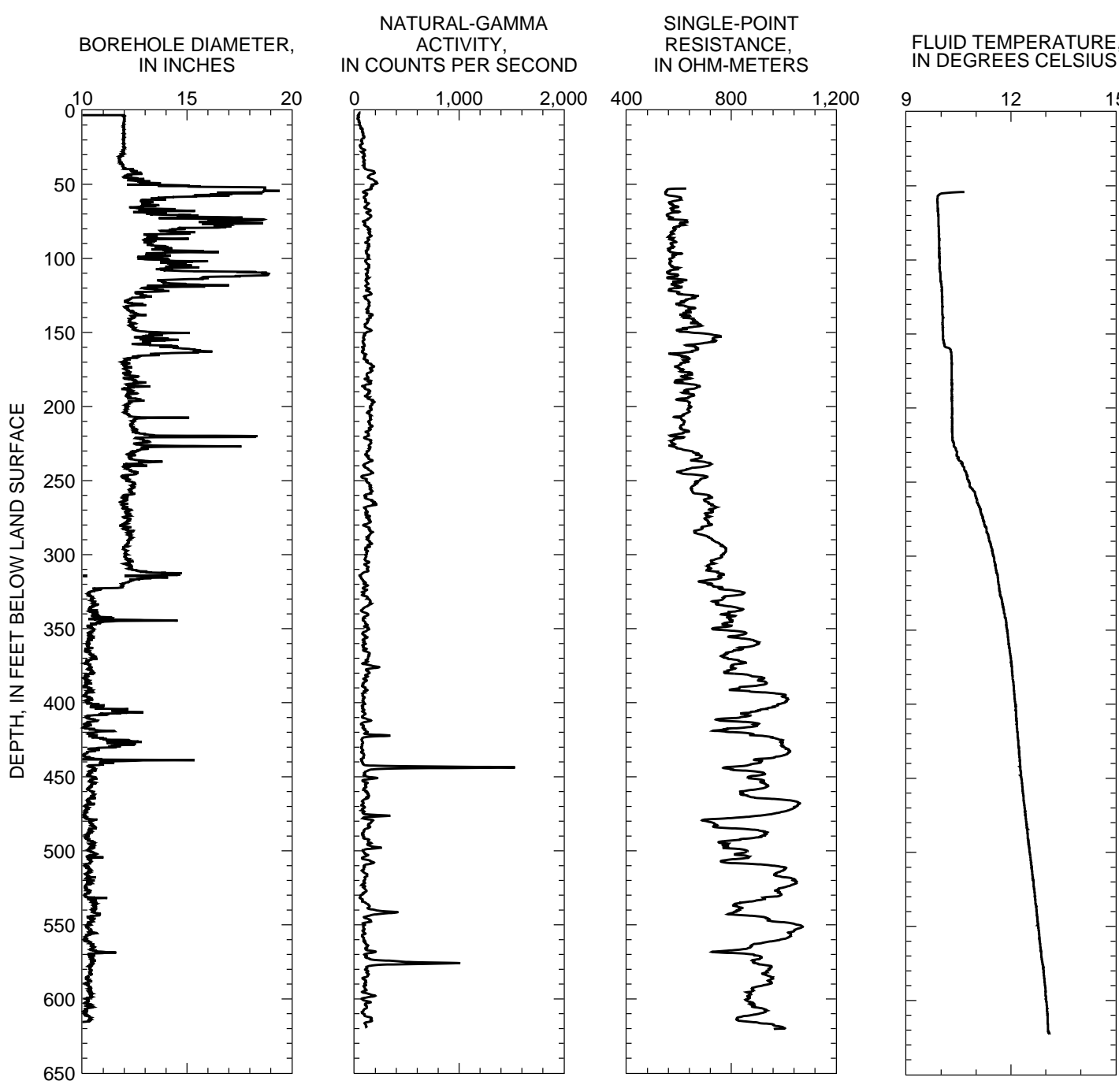

$0 \quad 1,000 \quad 2,000$
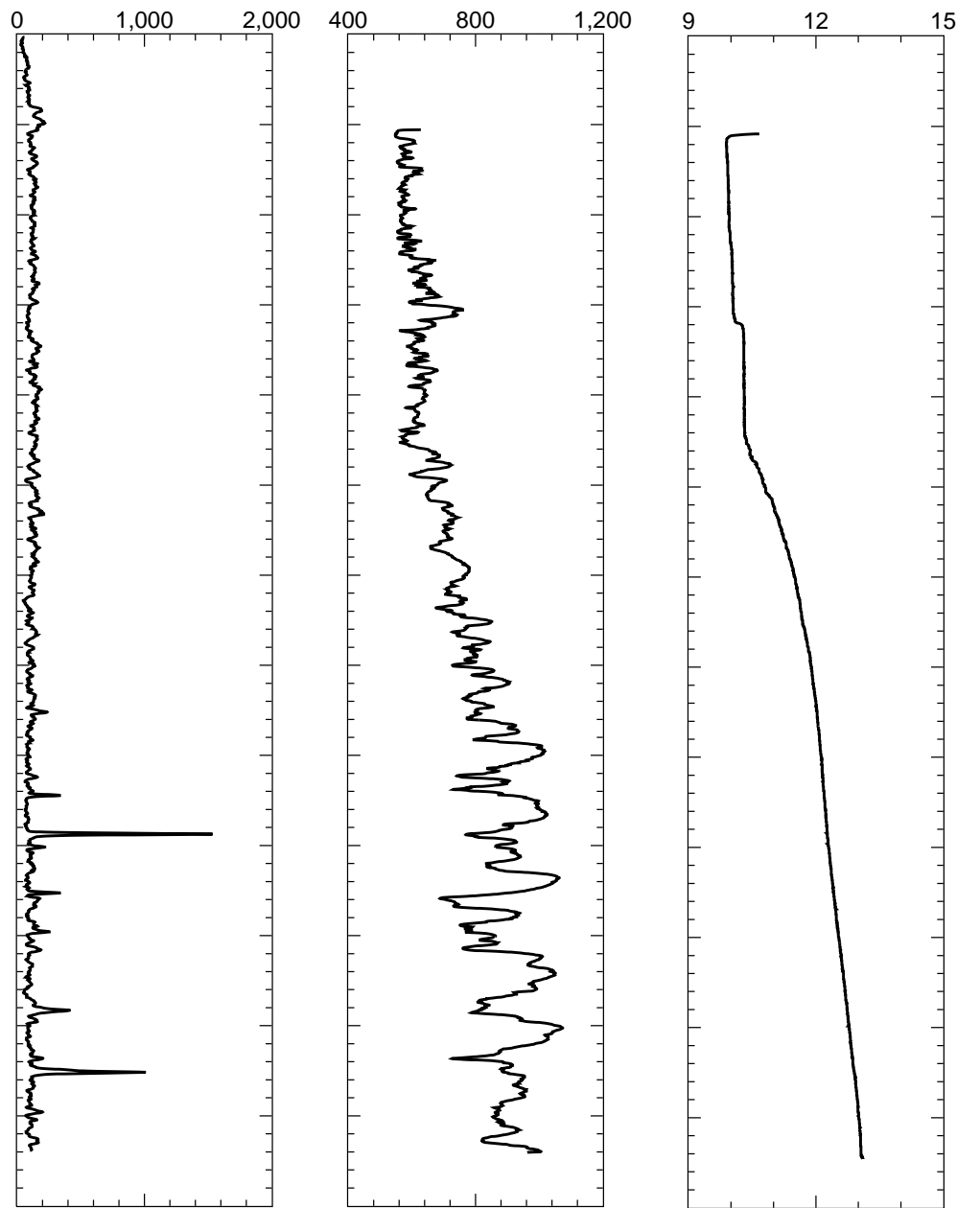

Figure 9. Borehole geophysical logs for borehole MG-202 (L-22), North Penn Area 7 Superfund site, Upper Gwynedd Township, Montgomery County, Pa.

(table 6) indicate that, under nonpumping conditions, water enters the borehole in the highly fractured intervals between 53 and 130 and 150 and $170 \mathrm{ft}$ bls, with a major water-bearing zone at $159-160 \mathrm{ft}$ bls, and exits the borehole in the interval between 212 and $223 \mathrm{ft}$ bls; most water probably exits through fractures at $220 \mathrm{ft}$ bls. Minor amounts of water may enter the borehole at about $253 \mathrm{ft}$ bls, move upward, and exit the borehole in the interval between 224 and $234 \mathrm{ft}$ bls. Accuracy of the heatpulse-flowmeter measurements in the interval between 53 and $170 \mathrm{ft}$ bls is uncertain because the extensive fracturing can allow some water to bypass the flowmeter. For measurements of flow under pumping conditions, a submersible pump was placed at $60 \mathrm{ft}$ bls and the well was pumped at an initial rate of about $1.3 \mathrm{gal} / \mathrm{min}$ for 5 minutes, a rate of $5.0 \mathrm{gal} / \mathrm{min}$ for 3 minutes, and then a constant rate about $5.3 \mathrm{gal} / \mathrm{min}$. After 25 minutes of pumping, the water level declined $2.33 \mathrm{ft}$ to $55.65 \mathrm{ft}$ bls. Heatpulse-flowmeter measurements made under pumping conditions indicate that the interval between 142 and $170 \mathrm{ft}$ bls is the most productive in the borehole. The fluidtemperature log shows most water production in this interval is through fractures at 159-160 ft bls. Elevated single-pointresistance readings (fig. 10) indicate the presence of a sandstone unit near the water-producing fractures at $159-160 \mathrm{ft}$ bls. 

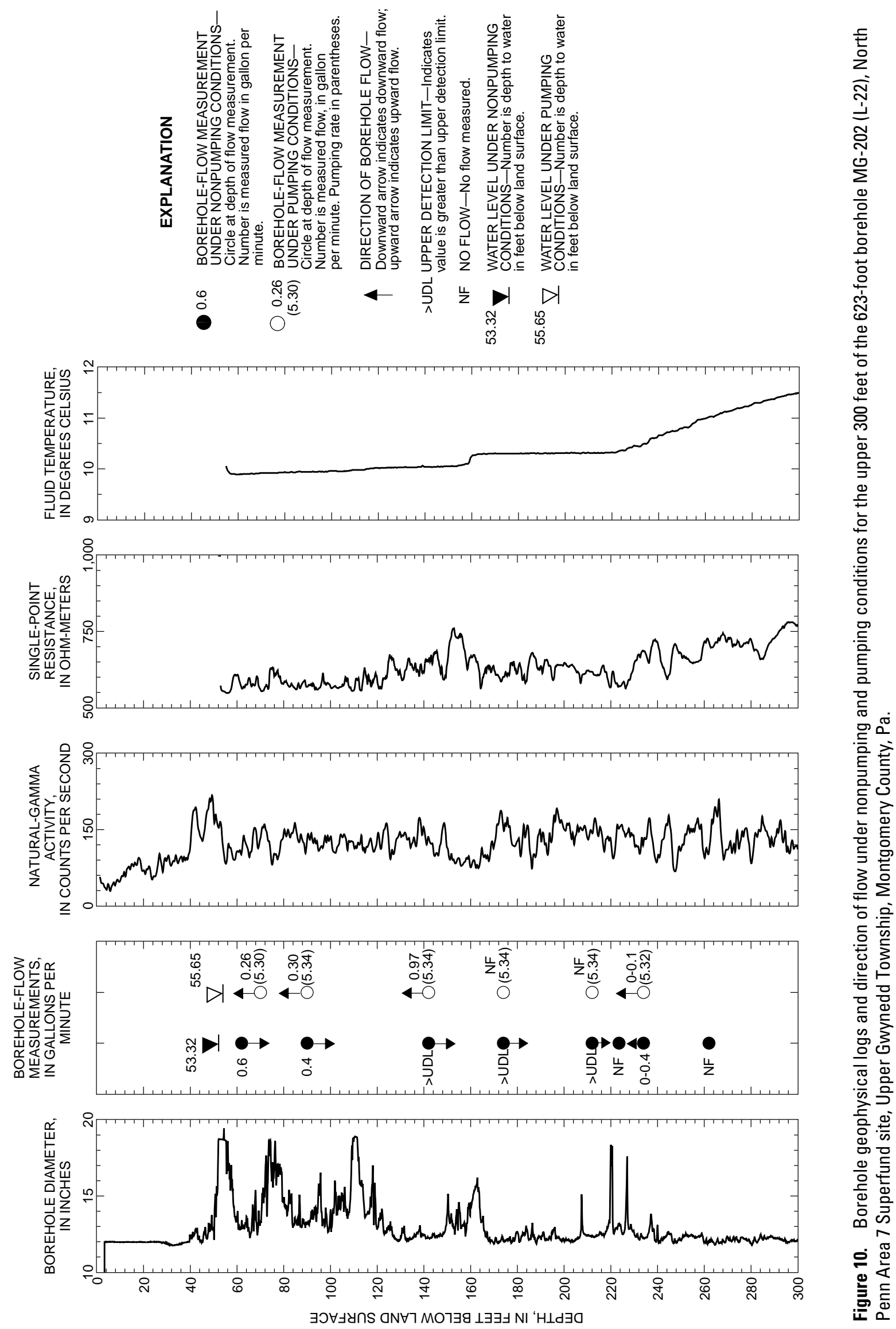
Table 6. Depths, flow rates, flow directions, and pumping rates of heatpulse-flowmeter measurements, under nonpumping and pumping conditions, for well MG-202 (L-22), North Penn Area 7 Superfund site, Upper Gwynedd Township, Montgomery County, $\mathrm{Pa}$.

[ft bls, feet below land surface; gal/min, gallons per minute; > UDL, greater than upper detection limit; NF, no flow measured; --, no data]

\begin{tabular}{|c|c|c|c|c|c|}
\hline \multirow{2}{*}{$\begin{array}{c}\text { Depth } \\
\text { of } \\
\text { measurement } \\
\text { (ft bls) }\end{array}$} & \multicolumn{2}{|c|}{$\begin{array}{l}\text { Nonpumping } \\
\text { conditions }\end{array}$} & \multicolumn{3}{|c|}{ Pumping conditions } \\
\hline & $\begin{array}{c}\text { Flow } \\
\text { rate } \\
\text { (gal/min) }\end{array}$ & $\begin{array}{c}\text { Flow } \\
\text { direction }\end{array}$ & $\begin{array}{c}\text { Flow } \\
\text { rate } \\
\text { (gal/min) }\end{array}$ & $\begin{array}{c}\text { Flow } \\
\text { direction }\end{array}$ & $\begin{array}{l}\text { Pumping } \\
\text { rate } \\
\text { (gal/min) }\end{array}$ \\
\hline 62 & 0.60 & down & -- & -- & -- \\
\hline 70 & -- & -- & 0.26 & up & 5.28 \\
\hline 90 & .40 & down & .30 & up & 5.32 \\
\hline 142 & $>$ UDL & down & .97 & up & 5.34 \\
\hline 174 & $>\mathrm{UDL}$ & down & NF & NF & 5.34 \\
\hline 212 & $>\mathrm{UDL}$ & down & NF & $\mathrm{NF}$ & 5.34 \\
\hline 223.5 & NF & NF & -- & -- & -- \\
\hline 234 & $0-.40$ & up & $0-.10$ & up & 5.32 \\
\hline 262 & $\mathrm{NF}$ & NF & -- & -- & -- \\
\hline
\end{tabular}

\section{Well MG-1144 (Teleflex T-13)}

The caliper log shows the total depth of the borehole is $84 \mathrm{ft}$ and it is cased with 6-in.-diameter plastic casing to about $18.5 \mathrm{ft}$ bls (fig. 11). The outer surface 8 -in. casing material is steel. The open borehole is $6 \mathrm{in}$. in diameter, and there are a few minor fractures throughout the borehole and major fractures at 80-84 ft bls at the bottom of the borehole. The borehole video shows possible water-bearing near-vertical fractures and openings at $48,58,75$, and $79-80 \mathrm{ft}$ bls and a near-horizontal fracture at $67 \mathrm{ft}$ bls.

The natural-gamma and single-point-resistance logs have a general inverse relation. For example, the natural-gamma log shows slightly depressed counts at 58-60, 76-78, and 80-

$82 \mathrm{ft}$ bls that correspond to slightly elevated single-point-resistance measurements at the same or similar zones (fig. 11). The natural-gamma and single-point-resistance logs indicate that lithology probably alternates between shales and sandstones.

The static water level at the time of logging was $31.35 \mathrm{ft}$ bls. The fluid-temperature log shows that temperature increases slightly with depth from the water level to about $50 \mathrm{ft}$ bls and below that depth is relatively constant. The relatively straight temperature profile below $50 \mathrm{ft}$ bls is consistent with vertical flow in the borehole. Under nonpumping conditions, the heatpulse flowmeter measured downward borehole flow at 40, 54, and $64 \mathrm{ft}$ bls and upward flow at 72 and $78 \mathrm{ft} \mathrm{bls}$ (table 7). These measurements (table 7) indicate that, under nonpumping conditions, water enters the borehole in the intervals between 33 and 40, 40 and 54, 54 and 64, 72 and 76, and
78 and $84 \mathrm{ft}$ bls and exits the borehole at the interval between 65 and $71 \mathrm{ft}$ bls. Some of these intervals (40-54, 54-64, 72-76, and $78-84 \mathrm{ft}$ bls) include zones of elevated single-point-resistance readings (48-64, 68-70, 74-76, and 78-84 ft bls) that possibly indicate sandstone units near depths of fractures shown on the caliper log. For measurements of flow under pumping conditions, a submersible pump was placed at $40 \mathrm{ft}$ bls and the well was pumped at a rate of less than $1 \mathrm{gal} / \mathrm{min}$. Heatpulseflowmeter measurements made under pumping conditions indicate that the intervals between $64-72$ and $78-84 \mathrm{ft}$ bls produce the greatest amount of water. These producing zones correspond to observed fractures shown on the caliper log at 6971 and 80-84 ft bls. After 27 minutes of pumping at less than $1 \mathrm{gal} / \mathrm{min}$, the water level declined $7.77 \mathrm{ft}$ to $39.12 \mathrm{ft}$ bls.

Table 7. Depths, flow rates, flow directions, and pumping rates of heatpulse-flowmeter measurements, under nonpumping and pumping conditions, for well MG-1144 (T-13), North Penn Area 7 Superfund site, Upper Gwynedd Township, Montgomery County, Pa.

[ft bls, feet below land surface; gal/min, gallon per minute; --, no data; <, less than]

\begin{tabular}{ccccccc}
\hline $\begin{array}{c}\text { Depth } \\
\text { of } \\
\text { measurement } \\
\text { (ft bls) }\end{array}$ & $\begin{array}{c}\text { Nonpumping } \\
\text { conditions }\end{array}$ & & \multicolumn{3}{c}{ Pumping conditions } \\
\cline { 2 - 3 } \cline { 5 - 7 } & $\begin{array}{c}\text { Flow } \\
\text { rate } \\
\text { (gal/min) }\end{array}$ & $\begin{array}{c}\text { Flow } \\
\text { direction }\end{array}$ & & $\begin{array}{c}\text { Flow } \\
\text { rate } \\
\text { (gal/min) }\end{array}$ & $\begin{array}{c}\text { Flow } \\
\text { direction }\end{array}$ & $\begin{array}{c}\text { Pumping } \\
\text { rate } \\
\text { (gal/min) }\end{array}$ \\
\hline 40 & 0.1 & down & -- & -- & -- \\
54 & .3 & down & & 0.59 & up & $<1$ \\
64 & .4 & down & & .44 & up & $<1$ \\
72 & .6 & up & & .84 & up & $<1$ \\
77 & -- & -- & & .71 & up & $<1$ \\
78 & .3 & up & -- & -- & -- \\
\hline
\end{tabular}

Interpretation of the acoustic-televiewer log (table 8) indicates that, at the time of geophysical logging, water-producing fractures were associated with high-angle (from 71 to 85 degrees) features at about 47, 59, 75, 79, and $83 \mathrm{ft}$ bls. These high-angle features generally strike northeast and dip northwest. One water-producing zone at about $35 \mathrm{ft}$ bls and a water-receiving zone at about 68 to $71 \mathrm{ft}$ bls are associated with low-angle (from 13 to 22 degrees) fractures. The fracture at $35 \mathrm{ft}$ bls strikes northeast and dips northwest. The waterreceiving fractures at 69 and $71 \mathrm{ft}$ bls strike northwest and dip northeast, whereas the fracture at $68 \mathrm{ft}$ bls strikes northeast and dips southeast. Bedding-plane features also intersect the borehole at relatively shallow angles (from 1.5 to 22 degrees) with an average strike and dip of about N. 79 degrees E., 20 degrees SE. During drilling, the borehole deviated from vertical about $0.35 \mathrm{ft}$ in a spiral direction from southwest to southeast, as determined from the deviation log (fig. 12). 

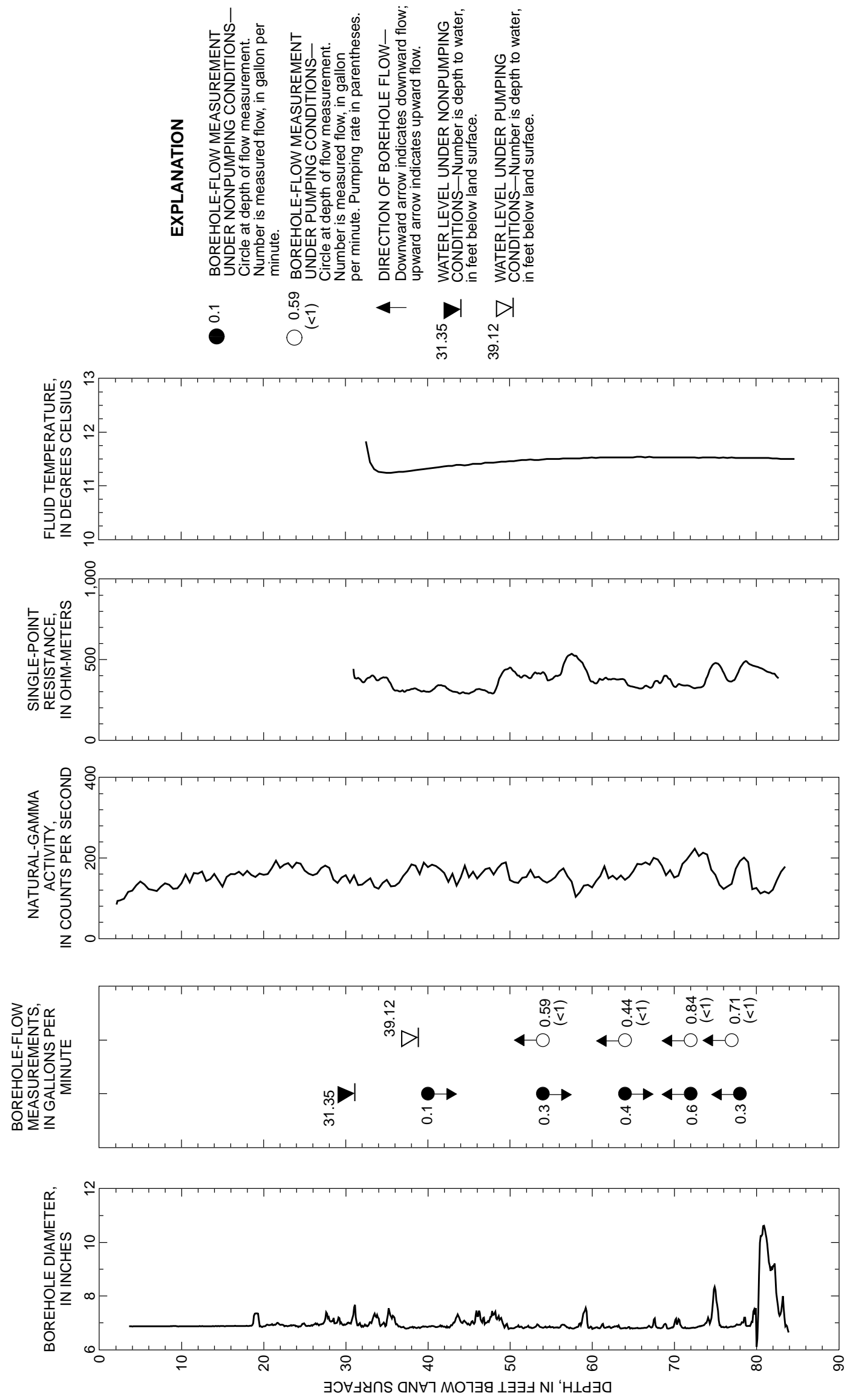
Table 8. Depth and orientation of bedding, fracture, and water-bearing features interpreted from the acoustic-televiewer log and borehole video survey for well MG-1144 (T-13), North Penn Area 7 Superfund site, Upper Gwynedd Township, Montgomery County, $\mathrm{Pa}$.

[ft bls, feet below land surface; Orientations: N, north; E, east; S; south, W; west; Feature type abbreviations: B, bedding plane; F, fracture; WB, water-bearing opening; ?, indicates uncertainty in feature type; water-bearing features are shown in bold typeface]

\begin{tabular}{|c|c|c|c|c|}
\hline \multirow{2}{*}{$\begin{array}{l}\text { Feature } \\
\text { depth } \\
\text { (ft bls) }\end{array}$} & \multicolumn{2}{|c|}{ Feature orientation } & \multirow{2}{*}{$\begin{array}{c}\text { Feature } \\
\text { type }\end{array}$} & \multirow[b]{2}{*}{ Borehole video survey observation } \\
\hline & $\begin{array}{c}\text { Strike } \\
\text { (degrees) }\end{array}$ & $\begin{array}{c}\text { Dip } \\
\text { (degrees) }\end{array}$ & & \\
\hline 33.0 & $\mathrm{~N} 49 \mathrm{~W}$ & $16 \mathrm{SW}$ & $\mathrm{B}$ & \\
\hline 34.8 & $\mathbf{N} 1 \mathbf{E}$ & $18 \mathrm{NW}$ & F/WB & High-angle fracture at $35 \mathrm{ft}$ bls \\
\hline 36.4 & $\mathrm{~N} 49 \mathrm{~W}$ & $2 \mathrm{SW}$ & $\mathrm{B}$ & Lithology change at $36 \mathrm{ft}$ bls \\
\hline 42.5 & N $84 \mathrm{~W}$ & $3 \mathrm{SW}$ & $\mathrm{B}$ & Rough walls at $43 \mathrm{ft}$ bls \\
\hline 46.6 & N 27 W & $78 \mathrm{NE}$ & F/WB & High-angle fracture at $46 \mathrm{ft}$ bls \\
\hline 46.7 & N 36 E & $72 \mathrm{NW}$ & F/WB & High angle fracture at $48-51 \mathrm{ft}$ bls \\
\hline 49.2 & N $66 \mathrm{E}$ & $20 \mathrm{SE}$ & $\mathrm{B}$ & \\
\hline 51.3 & N $85 \mathrm{E}$ & $21 \mathrm{SE}$ & B & \\
\hline 54.4 & N $69 \mathrm{E}$ & $9 \mathrm{SE}$ & B & \\
\hline 55.0 & N $34 \mathrm{E}$ & $15 \mathrm{SE}$ & $\mathrm{B}$ & \\
\hline $\mathbf{5 9 . 0}$ & N 88 E & 81 NW & F/WB & Filled high-angle fracture at 58-60 ft bls \\
\hline 61.6 & N $73 \mathrm{E}$ & $19 \mathrm{SE}$ & $\mathrm{B}$ & Lithology change at $62 \mathrm{ft}$ bls \\
\hline 67.7 & N 22 E & $13 \mathrm{SE}$ & B/WB? & Low-angle fracture at $67 \mathrm{ft}$ bls \\
\hline 69.0 & N 13 W & $20 \mathrm{NE}$ & F/WB? & Filled high-angle fractures \\
\hline 70.7 & N9 W & $22 \mathrm{NE}$ & B/WB? & Lithology change and low-angle fracture at $70 \mathrm{ft}$ bls \\
\hline 73.3 & N $30 \mathrm{E}$ & $22 \mathrm{SE}$ & $\mathrm{B}$ & \\
\hline 73.8 & N $83 \mathrm{E}$ & $2 \mathrm{NW}$ & $\mathrm{B}$ & Low-angle fracture at $74 \mathrm{ft}$ bls \\
\hline 74.6 & N 63 E & $81 \mathrm{NW}$ & F/WB & High-angle fracture at $75-77 \mathrm{ft}$ bls \\
\hline 79.3 & N 65 E & 75 NW & F/WB & High-angle fracture opens at $79.5 \mathrm{ft}$ bls \\
\hline 82.6 & N $48 \mathrm{E}$ & 85 NW & F/WB & \\
\hline
\end{tabular}

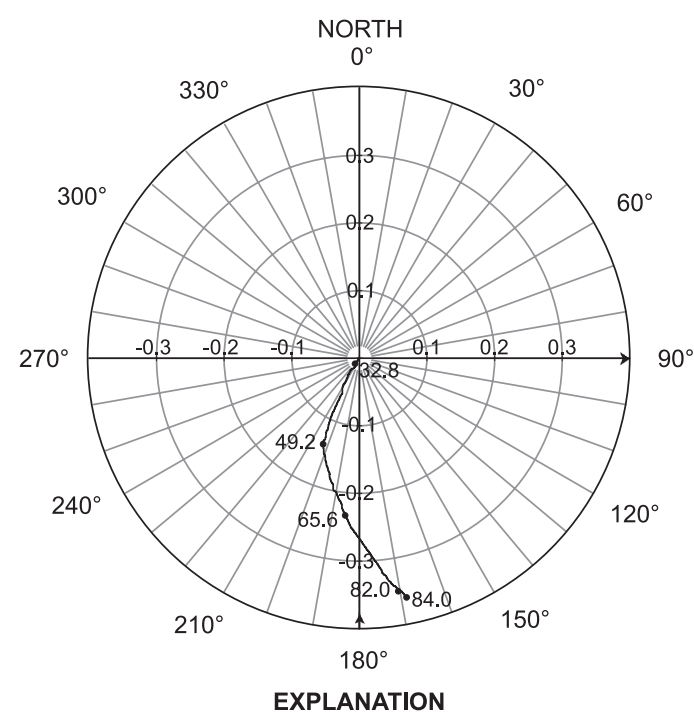

DIRECTION AND MAGNITUDE OF

DEVIATION -- Direction shown by trace of line relative to azimuth in degrees from true north. Magnitude, in feet, shown by location of trace relative to concentric circles

49.2 - MEASUREMENT OF BOREHOLE DEPTH, IN FEET
Figure 12. Borehole-deviation log showing direction (in degrees) and magnitude (in feet) of hole deviation from water level to the bottom of the borehole for well MG-1144 (T-13), North Penn Area 7 Superfund site, Upper Gwynedd Township, Montgomery County, $\mathrm{Pa}$. 


\section{Well MG-1145 (Teleflex T-14)}

The caliper log shows that the total depth of the borehole is $83 \mathrm{ft}$ and it is cased with 6-in.-diameter plastic casing to about $19 \mathrm{ft}$ bls (fig. 13). The outer surface 8-in. casing material is steel. The caliper log shows the open borehole is 6 in. in diameter. There are a few minor fractures throughout the borehole and a major fracture at the bottom of the borehole. The largest fractures are in the interval between 80 and $83 \mathrm{ft}$ bls. The borehole video shows possible water-bearing near-vertical fractures and openings at 33, 73, and $79 \mathrm{ft}$ bls and a near-horizontal fracture at $31 \mathrm{ft}$ bls.

The natural-gamma and single-point-resistance logs generally have an inverse relation. For example, the naturalgamma log shows slightly depressed counts at 30, 33, 36, 7476 , and 78-80 ft bls that correspond to slightly elevated singlepoint-resistance measurements at the same or similar zones (fig. 13). The natural-gamma and single-point-resistance logs indicate lithology probably alternates between shale and sandstone.

The static water level at the time of logging was $26.80 \mathrm{ft}$ bls. The fluid-temperature log shows a relatively straight temperature profile consistent with vertical flow in the borehole. Under nonpumping conditions, the heatpulse flowmeter measured downward flow at 35, 46, 55, 59, 68, and $78 \mathrm{ft}$ bls and no flow at $30 \mathrm{ft}$ bls (table 9). These measurements (table 9) indicate that, under nonpumping conditions, water probably enters the borehole in the intervals between 31 and $34 \mathrm{ft}$ bls and primarily exits the borehole at the intervals between 60 and 68 and 78 and $83 \mathrm{ft} \mathrm{bls,} \mathrm{although} \mathrm{a} \mathrm{minor}$ amount of flow also may exit between 46 and $55 \mathrm{ft}$ bls. For measurements of flow under pumping conditions, a submersible pump was placed at $35 \mathrm{ft}$ bls and the well was pumped at a rate of about $2 \mathrm{gal} / \mathrm{min}$. Heatpulse-flowmeter measurements made under pumping conditions indicate that the intervals between 31 and 35,59 and 68, and 78 and $83 \mathrm{ft}$ bls produce similar amounts of water. These producing zones correspond to observed fractures at 31-34, 59-61, and 79-83 ft bls on the caliper $\log$. Fractures at 31-34 and 79-83 ft bls are at similar depths of intervals with elevated single-point-resistance readings that possibly indicate sandstone units. After 30 minutes of pumping at about $2 \mathrm{gal} / \mathrm{min}$, the water level declined $0.55 \mathrm{ft}$ to $27.35 \mathrm{ft}$ bls.

Table 9. Depths, flow rates, flow directions, and pumping rates of heatpulse-flowmeter measurements, under nonpumping and pumping conditions, for well MG-1145 (T-14), North Penn Area 7 Superfund site, Upper Gwynedd Township, Montgomery County, $\mathrm{Pa}$.

[ft bls, feet below land surface; gal/min, gallons per minute; NF, no flow measured; --, no data]

\begin{tabular}{ccccccc}
\hline $\begin{array}{c}\text { Depth } \\
\text { of } \\
\begin{array}{c}\text { measurement } \\
\text { (ft bls) }\end{array}\end{array}$ & \multicolumn{2}{c}{$\begin{array}{c}\text { Nonpumping } \\
\text { conditions }\end{array}$} & & \multicolumn{3}{c}{ Pumping conditions } \\
\cline { 2 - 3 } \cline { 6 - 7 } & $\begin{array}{c}\text { Flow } \\
\text { rate } \\
\text { (gal/min) }\end{array}$ & $\begin{array}{c}\text { Flow } \\
\text { direction }\end{array}$ & & $\begin{array}{c}\text { Flow } \\
\text { rate } \\
\text { (gal/min) }\end{array}$ & $\begin{array}{c}\text { Flow } \\
\text { direction }\end{array}$ & $\begin{array}{c}\text { Pumping } \\
\text { rate } \\
\text { (gal/min) }\end{array}$ \\
\hline 30 & NF & NF & -- & -- & -- \\
35 & 0.5 & down & & - & -- & -- \\
46 & .6 & down & & 1.28 & up & 2.01 \\
55 & .5 & down & & -- & -- & -- \\
59 & .4 & down & & 1.16 & up & 1.95 \\
68 & .25 & down & & .44 & up & 2.01 \\
78 & .22 & down & & .63 & up & 2.00 \\
\hline
\end{tabular}

Interpretation of the acoustic-televiewer log (table 10) indicates that water-producing fractures intersect the borehole at low to moderate angles (from 16 to 29 degrees). At the time of geophysical logging, a water-producing zone was associated with moderate-angle features at about $33 \mathrm{ft}$ bls that strike northeast and dip southeast. Under nonpumping conditions, water-receiving zones are associated with high-angle features at 57, 73-75, and $83 \mathrm{ft}$ bls that strike northeast and dip northwest and also possibly with moderate-angle fractures that strike both northeast and northwest at about $53 \mathrm{ft}$ bls. Beddingplane features intersect the borehole at relatively shallow angles (from 0 to 41 degrees) and most frequently appear to strike northeast, dipping both to the northwest and southeast. During drilling, the borehole deviated from vertical about $0.8 \mathrm{ft}$ to the southeast, as determined from the deviation log (fig. 14). 

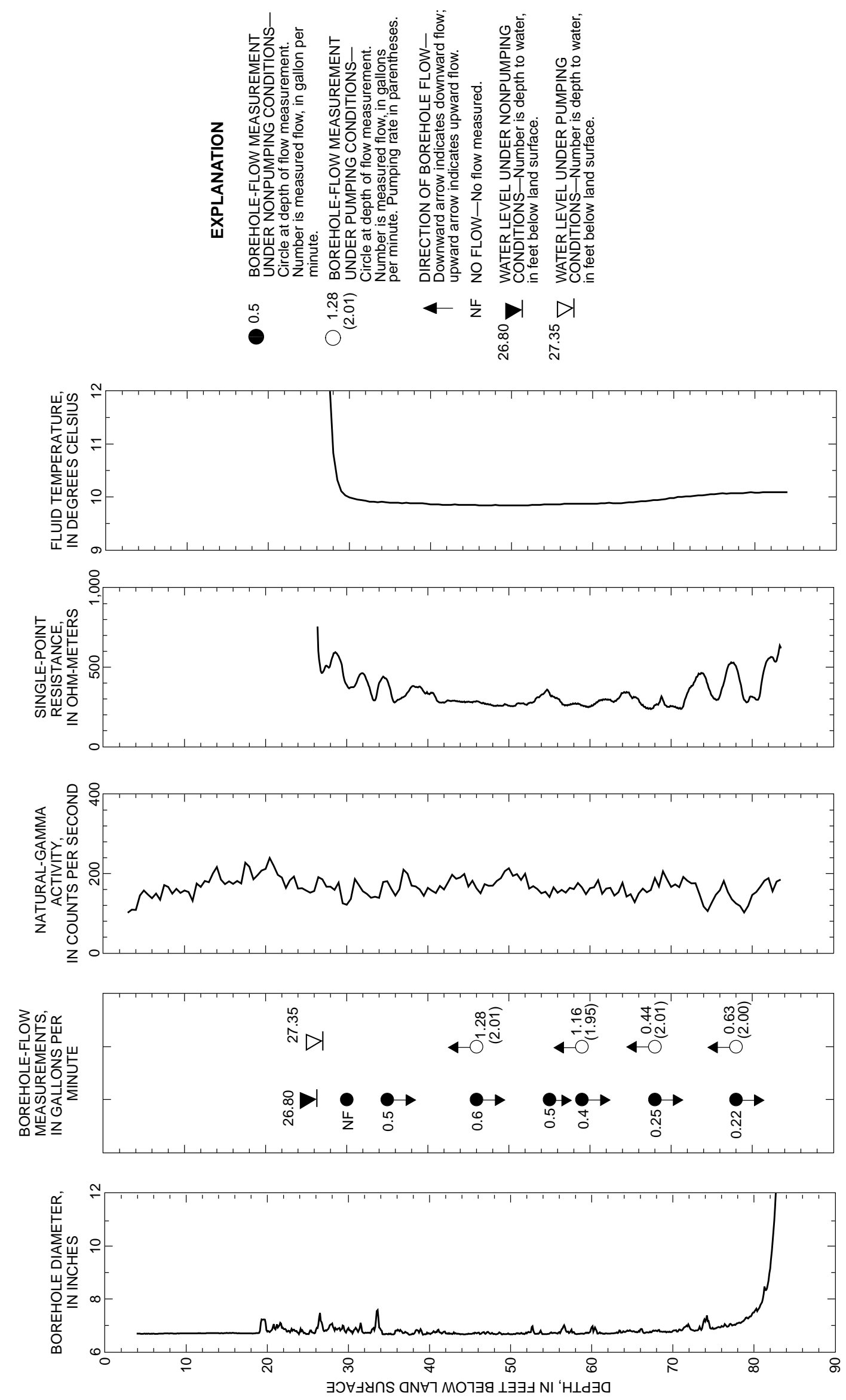
Table 10. Depth and orientation of bedding, fracture, and water-bearing features interpreted from the acousticteleviewer log and borehole video survey for well MG-1145 (T-14), North Penn Area 7 Superfund site, Upper Gwynedd Township, Montgomery County, Pa.

[ft bls, feet below land surface; Orientations: N, north; E, east; S; south, W; west; --, not determined; Feature type abbreviations: B, bedding plane; F, fracture; WB, water-bearing opening; ?, indicates uncertainty in feature type; water-bearing features are shown in bold typeface]

\begin{tabular}{|c|c|c|c|c|}
\hline \multirow{2}{*}{$\begin{array}{l}\text { Feature depth } \\
\qquad \text { (ft bls) }\end{array}$} & \multicolumn{2}{|c|}{ Feature orientation } & \multirow[b]{2}{*}{ Feature type } & \multirow[b]{2}{*}{ Borehole video survey observation } \\
\hline & $\begin{array}{c}\text { Strike } \\
\text { (degrees) }\end{array}$ & $\begin{array}{c}\text { Dip } \\
\text { (degrees) }\end{array}$ & & \\
\hline 28.2 & N $38 \mathrm{E}$ & $15 \mathrm{SE}$ & $\mathrm{B}$ & Low-angle fracture at $28 \mathrm{ft}$ bls \\
\hline 29.3 & N $60 \mathrm{~W}$ & $18 \mathrm{NE}$ & $\mathrm{B}$ & \\
\hline 30.0 & N $67 \mathrm{~W}$ & $21 \mathrm{SW}$ & $\mathrm{B}$ & \\
\hline 30.4 & N $82 \mathrm{E}$ & $16 \mathrm{SE}$ & $\mathrm{B}$ & Low-angle fracture at $31 \mathrm{ft} \mathrm{bls}$ \\
\hline 32.8 & $\mathrm{~N} 44 \mathrm{E}$ & $9 \mathrm{SE}$ & $\mathrm{F}$ & \\
\hline 33.4 & N 61 E & $18 \mathrm{SE}$ & F/WB & High-angle fractures at $33 \mathrm{ft}$ bls \\
\hline 33.5 & N 73 E & $16 \mathrm{SE}$ & F/WB & \\
\hline 33.6 & N $73 \mathrm{E}$ & $2 \mathrm{NW}$ & $\mathrm{F}$ & \\
\hline 33.9 & N $27 \mathrm{~W}$ & $20 \mathrm{NE}$ & $\mathrm{F}$ & \\
\hline 34.0 & N $10 \mathrm{~W}$ & $8 \mathrm{NE}$ & $\mathrm{F}$ & \\
\hline 35.1 & N 33 E & $11 \mathrm{SE}$ & $\mathrm{B}$ & \\
\hline 35.7 & N $75 \mathrm{~W}$ & $13 \mathrm{SW}$ & $\mathrm{B}$ & \\
\hline 36.4 & N 19 W & $24 \mathrm{SW}$ & $\mathrm{B}$ & \\
\hline 36.9 & N $55 \mathrm{~W}$ & $29 \mathrm{SW}$ & $\mathrm{B}$ & \\
\hline 37.0 & $\mathrm{~N} 71 \mathrm{E}$ & $13 \mathrm{SE}$ & $\mathrm{B}$ & \\
\hline 41.8 & N 38 E & $12 \mathrm{SE}$ & $\mathrm{B}$ & Lithology change at $41 \mathrm{ft}$ bls \\
\hline 47.1 & N $65 \mathrm{E}$ & $24 \mathrm{SE}$ & $\mathrm{B}$ & \\
\hline 52.6 & N 52 W & $29 \mathrm{SW}$ & WB? & \\
\hline 53.6 & N 34 E & $23 \mathrm{SE}$ & WB? & \\
\hline 53.6 & N $49 \mathrm{E}$ & $18 \mathrm{NW}$ & WB? & \\
\hline 54.8 & N $87 \mathrm{E}$ & $22 \mathrm{SE}$ & $\mathrm{B}$ & Low-angle fracture at $55 \mathrm{ft}$ bls \\
\hline 56.5 & $\mathrm{~N} 40 \mathrm{E}$ & $14 \mathrm{SE}$ & $\mathrm{B}$ & \\
\hline 56.8 & N $67 \mathrm{E}$ & $19 \mathrm{SE}$ & B & \\
\hline 57.1 & N 68 E & $75 \mathrm{NW}$ & F/WB & \\
\hline 65.8 & N $46 \mathrm{~W}$ & $28 \mathrm{NE}$ & $\mathrm{B}$ & \\
\hline 66.4 & N $39 \mathrm{E}$ & $40 \mathrm{NW}$ & $\mathrm{B}$ & Light-colored bed at $67 \mathrm{ft}$ bls \\
\hline 71.4 & N 14 E & $41 \mathrm{SE}$ & $\mathrm{B}$ & \\
\hline 72.0 & N $10 \mathrm{~W}$ & $11 \mathrm{NE}$ & $\mathrm{B}$ & \\
\hline 73 & -- & -- & $\mathbf{F}$ & High-angle fracture \\
\hline 75.5 & N $64 \mathrm{E}$ & $82 \mathrm{NW}$ & $\mathrm{F}$ & Filled high-angle fracture at $75 \mathrm{ft} b l s$ \\
\hline 79.2 & N $3 \mathrm{~W}$ & $28 \mathrm{NE}$ & $\mathrm{B}$ & Moderate-angle fracture at $79 \mathrm{ft}$ bls \\
\hline 80.1 & N $80 \mathrm{E}$ & $29 \mathrm{NW}$ & $\mathrm{B}$ & \\
\hline 81.4 & N $87 \mathrm{~W}$ & $27 \mathrm{SW}$ & B & Filled vertical fracture at $81 \mathrm{ft}$ bls \\
\hline 82.7 & N $77 \mathbf{E}$ & $79 \mathrm{NW}$ & F/WB & \\
\hline
\end{tabular}




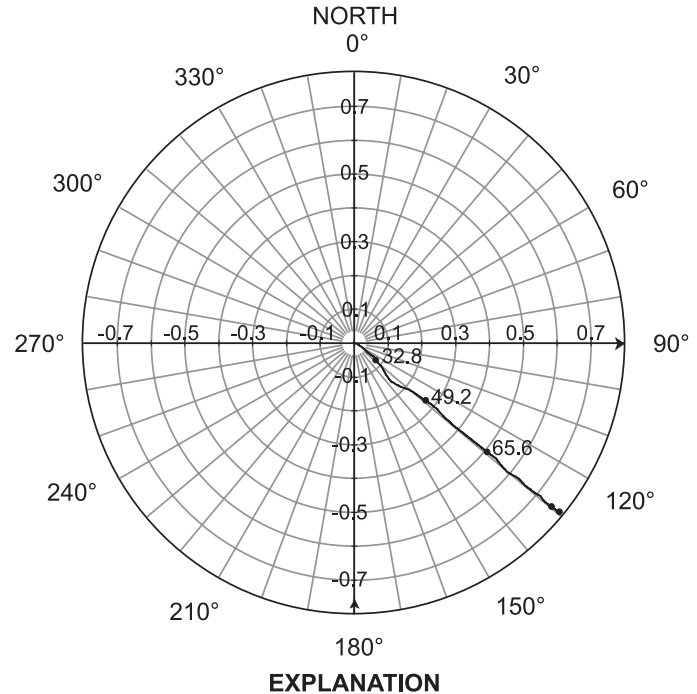

EXPLANATION

DIRECTION AND MAGNITUDE OF DEVIATION -- Direction shown by trace of line relative to azimuth in degrees from true north. Magnitude, in feet, shown by location of trace relative to concentric circles

49.2 MEASUREMENT OF BOREHOLE DEPTH, IN FEET

Figure 14. Borehole-deviation log showing direction (in degrees) and magnitude (in feet) of hole deviation from water level to the bottom of the borehole for well MG-1145 (T-14), North Penn Area 7 Superfund site, Upper Gwynedd Township, Montgomery County, $\mathrm{Pa}$.

\section{Well MG-1146 (Teleflex T-4)}

The caliper log shows that the total depth of the borehole is $84.5 \mathrm{ft}$ and it is cased with 6-in.-diameter plastic casing to about $18.5 \mathrm{ft}$ bls (fig. 15). The outer surface 8 -in. casing material is steel. The caliper log shows the open borehole is 6 in. in diameter. There are a few minor fractures throughout the borehole and a major fracture at $56-58 \mathrm{ft}$ bls. The borehole video shows possible water-bearing near-vertical fractures and openings at 47, 56, 76, 77, and $82 \mathrm{ft}$ bls.

The natural-gamma and single-point-resistance logs generally have an inverse relation. For example, the naturalgamma log shows slightly elevated single-point-resistance measurements that correspond to slightly depressed counts at 46-52 and 57-60 ft bls at the same or similar zones (fig. 15). The natural-gamma and single-point-resistance logs indicate that lithology probably alternates between shale and sandstone.

The static water level at the time of logging was $37.33 \mathrm{ft}$ bls. The fluid-temperature log shows that temperature decreases with depth. The temperature profile is consistent with little to no vertical flow in the borehole. Under nonpumping conditions, the heatpulse flowmeter measured no detect- able flow at 44, 54, 66, and $76 \mathrm{ft}$ bls (table 11). For measurements of flow under pumping conditions, a submersible pump was placed at $50 \mathrm{ft}$ bls and the well was pumped at a rate of about $1 \mathrm{gal} / \mathrm{min}$. Heatpulse-flowmeter measurements made under pumping conditions indicate that the interval between 55 and $66 \mathrm{ft}$ bls is the most productive, with lesser production from the interval between 76 and $84.5 \mathrm{ft}$ bls. These producing zones correspond to observed fractures at 56-58 and 76-77 or $82-84 \mathrm{ft}$ bls on the caliper log. After 35 minutes of pumping at about $1 \mathrm{gal} / \mathrm{min}$, the water level declined $4.33 \mathrm{ft}$ to $41.66 \mathrm{ft}$ bls.

Interpretation of the acoustic-televiewer log (table 12) indicates that approximately five fractures between 43 and $54 \mathrm{ft}$ bls intersect the borehole at moderate to high angles (from 33 to 62 degrees) in various orientations. None of these fractures were associated with apparent water-bearing zones. A bedding-plane feature also intersects the borehole at $49 \mathrm{ft}$ bls at relatively shallow angles (about 11 degrees) and strikes nearly due east, dipping north. Acoustic-televiewer data were not available for depths below $55 \mathrm{ft}$ bls, where waterbearing zones are indicated by other logs. During drilling, the borehole deviated from vertical about $0.7 \mathrm{ft}$ to the southeast, as determined from the deviation log (fig. 16). 

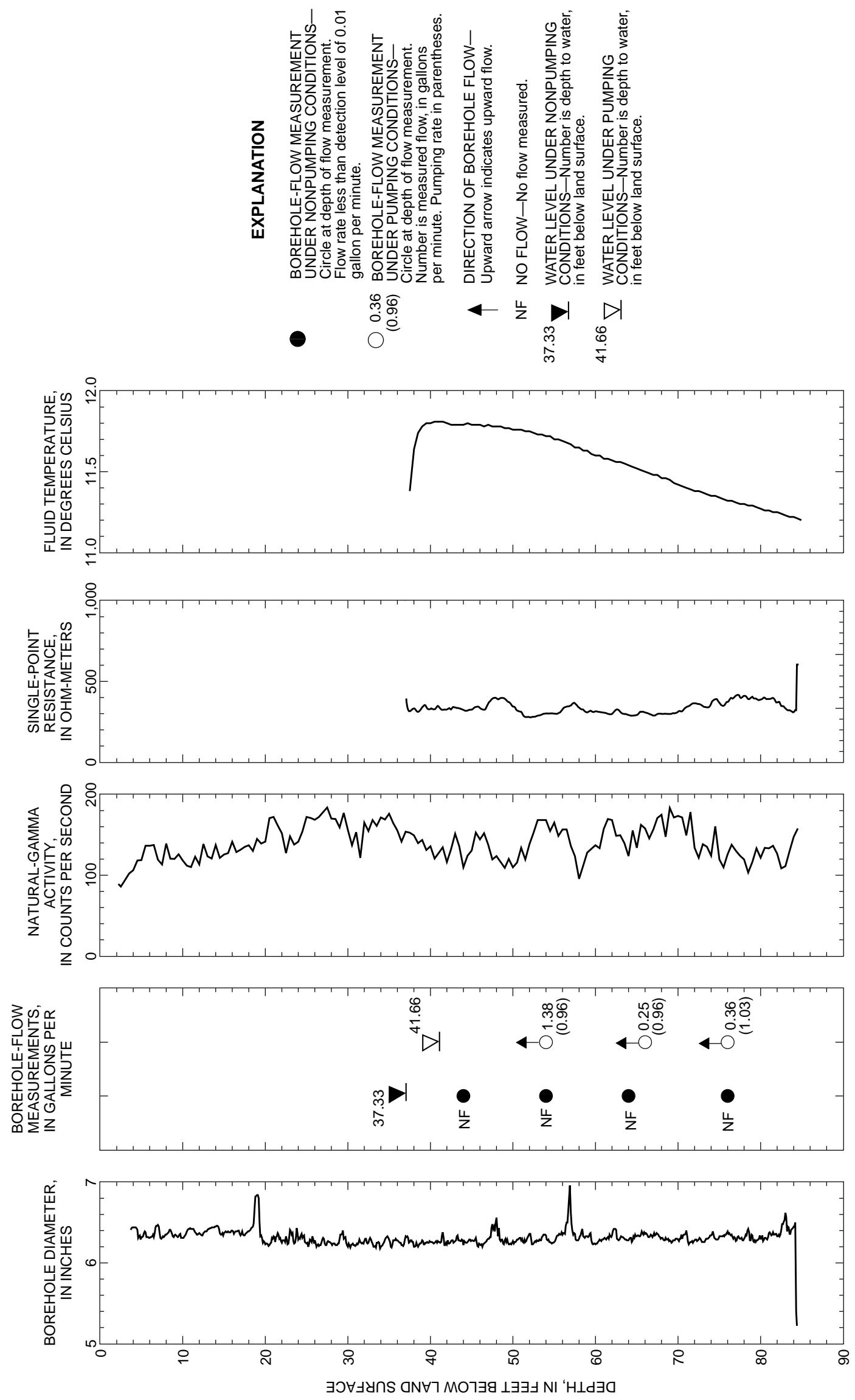

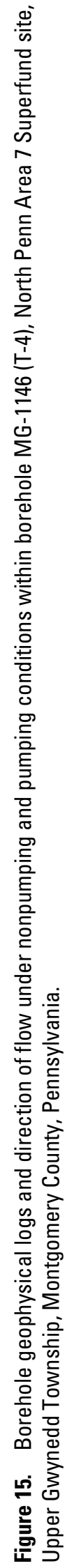


Table 11. Depths, flow rates, flow directions, and pumping rates of heatpulse-flowmeter measurements, under nonpumping and pumping conditions, for well MG-1146 (T-4), North Penn Area 7 Superfund site, Upper Gwynedd Township, Montgomery County, $\mathrm{Pa}$.

[ft bls, feet below land surface; gal/min, gallons per minute; NF, no flow measured; --, no data]

\begin{tabular}{|c|c|c|c|c|c|}
\hline \multirow{2}{*}{$\begin{array}{c}\text { Depth of } \\
\text { measurement } \\
\text { (ft bls) }\end{array}$} & \multicolumn{2}{|c|}{$\begin{array}{l}\text { Nonpumping } \\
\text { conditions }\end{array}$} & \multicolumn{3}{|c|}{ Pumping conditions } \\
\hline & $\begin{array}{l}\text { Flow rate } \\
\text { (gal/min) }\end{array}$ & $\begin{array}{c}\text { Flow } \\
\text { direction }\end{array}$ & $\begin{array}{l}\text { Flow rate } \\
\text { (gal/min) }\end{array}$ & $\begin{array}{c}\text { Flow } \\
\text { direction }\end{array}$ & $\begin{array}{c}\text { Pumping } \\
\text { rate } \\
\text { (gal } / \mathrm{min} \text { ) }\end{array}$ \\
\hline 44 & $\mathrm{NF}$ & $\mathrm{NF}$ & -- & -- & -- \\
\hline 54 & $\mathrm{NF}$ & NF & ${ }^{1} 1.38$ & up & 0.96 \\
\hline 66 & $\mathrm{NF}$ & $\mathrm{NF}$ & .25 & up & .96 \\
\hline 76 & NF & NF & .36 & up & 1.03 \\
\hline
\end{tabular}

${ }^{1}$ Apparent turbulence may affect reported value.

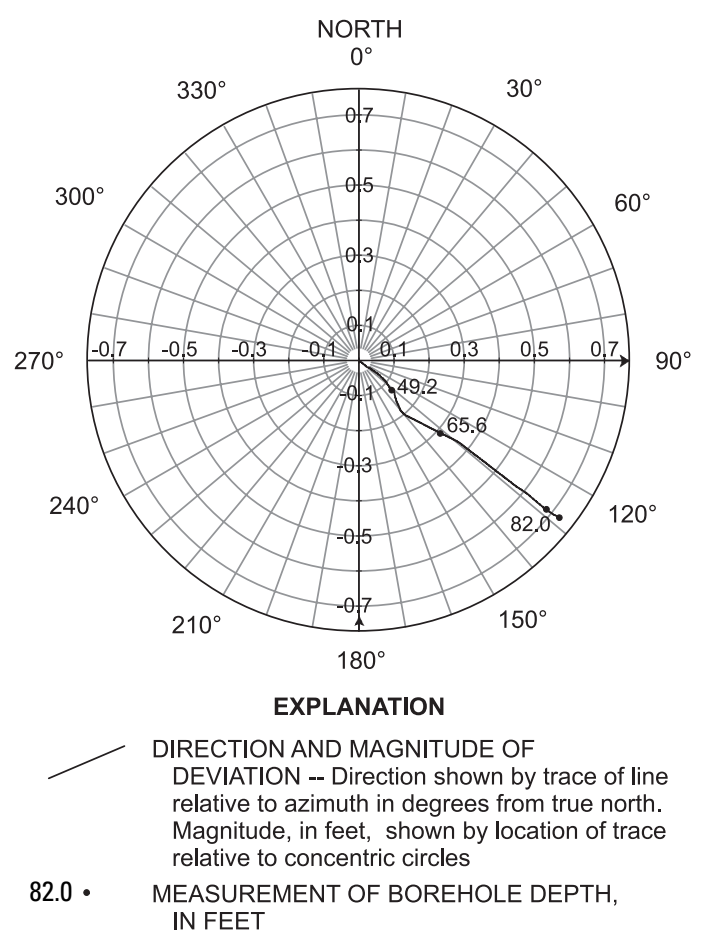

Figure 16. Borehole-deviation log showing direction (in degrees) and magnitude (in feet) of hole deviation from water level to the bottom of the borehole for well MG-1146 (T-4), North Penn Area 7 Superfund site, Upper Gwynedd Township, Montgomery County, Pa.

Table 12. Depth and orientation of bedding, fracture, and water-bearing features interpreted from the acoustic-televiewer log and borehole video survey for well MG-1146 (T-4), North Penn Area 7 Superfund site, Upper Gwynedd Township, Montgomery County, Pa.

[ft bls, feet below land surface; Orientations: N, north; E, east; S; south, W; west; --, not determined; Feature type abbreviations: B, bedding plane; F, fracture; WB, water-bearing opening; ?, indicates uncertainty in feature type; water-bearing features are shown in bold typeface]

\begin{tabular}{|c|c|c|c|c|}
\hline \multirow{2}{*}{$\begin{array}{l}\text { Feature } \\
\text { depth } \\
\text { (ft bls) }\end{array}$} & \multicolumn{2}{|c|}{ Feature orientation } & \multirow[b]{2}{*}{$\begin{array}{c}\text { Feature } \\
\text { type }\end{array}$} & \multirow[b]{2}{*}{ Borehole video survey observation } \\
\hline & $\begin{array}{c}\text { Strike } \\
\text { (degrees) }\end{array}$ & $\begin{array}{c}\text { Dip } \\
\text { (degrees) }\end{array}$ & & \\
\hline 43.1 & N $85 \mathrm{~W}$ & $56 \mathrm{SW}$ & $\mathrm{F}$ & \\
\hline 47.6 & $\mathrm{~N} 4 \mathrm{~W}$ & $33 \mathrm{SW}$ & $\mathrm{F}$ & High-angle fracture at $47 \mathrm{ft}$ bls \\
\hline 48.0 & N $64 \mathrm{~W}$ & $62 \mathrm{NE}$ & $\mathrm{F}$ & \\
\hline 48.7 & N $87 \mathrm{E}$ & $11 \mathrm{NW}$ & $\mathrm{B}$ & \\
\hline 53.8 & N $16 \mathrm{E}$ & $51 \mathrm{NW}$ & $\mathrm{F}$ & \\
\hline 56 & -- & -- & F/WB & High-angle fracture \\
\hline 76 & -- & -- & F/WB? & Large opening, multiple fractures? \\
\hline 77 & -- & -- & F/WB? & High- and low-angle fractures \\
\hline 82 & -- & -- & F/WB? & Rough, high- and low angle fractures \\
\hline
\end{tabular}




\section{Well MG-1147 (Teleflex T-11)}

The caliper log shows that the total depth of the borehole is $83.5 \mathrm{ft}$ and it is cased with 6-in.-diameter plastic casing to about $18 \mathrm{ft}$ bls (fig. 17). The outer surface 8-in. casing material is steel. The caliper log shows that the open borehole is 6 in. in diameter. There are a few minor fractures throughout the borehole. The borehole video shows a possible water-bearing opening or near-vertical fracture at $66 \mathrm{ft}$ bls.

The natural-gamma and single-point-resistance logs show little variability (fig. 17) and commonly have an inverse relation. The natural-gamma log shows slightly elevated counts at 32-38 ft bls and slightly depressed counts at 18-22 and 67$69 \mathrm{ft}$ bls. The single-point-resistance log shows slightly elevated measurements at 48,67 , and $70 \mathrm{ft}$ bls that may be associated with sandstone units.

The static water level at the time of logging was $39.19 \mathrm{ft}$ bls. The fluid-temperature log shows that temperature decreases slightly with depth. The temperature profile is consistent with little to no vertical flow in the borehole. Under nonpumping conditions, the heatpulse flowmeter measured no detectable flow at 48, 52, 62, and $74 \mathrm{ft}$ bls (table 13). For measurements of flow under pumping conditions, a submersible pump was placed at $50 \mathrm{ft}$ bls and the well was pumped at a rate of about $1 \mathrm{gal} / \mathrm{min}$. Prior to pumping, the static water level was $39.43 \mathrm{ft}$ bls. Heatpulse-flowmeter measurements made under pumping conditions indicate that the intervals between 62 and 74 and 74 and $83.5 \mathrm{ft}$ bls are the most productive. These producing zones correspond to observed fractures at 67-68 and $82 \mathrm{ft}$ bls on the caliper log. After 20 minutes of pumping at about $0.8 \mathrm{gal} / \mathrm{min}$, the water level declined $7.01 \mathrm{ft}$ to $46.20 \mathrm{ft}$ bls.

Interpretation of the acoustic-televiewer log (table 14) indicates that possible water-bearing fractures intersect the borehole at relatively low (from 16 to 22 degrees) and moder- ate angles (48 degrees). At the time of geophysical logging, water-producing zones were associated with low-angle features at about 68 and $82 \mathrm{ft}$ bls that strike northeast (dipping southeast) and northwest (dipping northeast), respectively. Another water-producing zone is associated with a moderateangle feature at about $82 \mathrm{ft}$ bls that strikes northeast, dipping southeast. Bedding-plane features also intersect the borehole at about 71 and $75 \mathrm{ft}$ bls at relatively shallow angles (from 11 to 23 degrees) and strike northwest, dipping both to the northeast and southwest. Other fractures or bedding-plane features intersect the borehole at shallow angles (from 14 to 25 degrees) from 48 to $54 \mathrm{ft}$ bls. Some of these features strike northeast and dip southeast and others strike northwest and dip northeast. During drilling, the borehole deviated from vertical about $0.8 \mathrm{ft}$ to the southeast, as determined from the deviation log (fig. 18).

Table 13. Depths, flow rates, flow directions, and pumping rates of heatpulse-flowmeter measurements, under nonpumping and pumping conditions, for well MG-1147 (T-11), North Penn Area 7 Superfund site, Upper Gwynedd Township, Montgomery County, $\mathrm{Pa}$.

[ft bls, feet below land surface; gal/min, gallons per minute; NF, no flow measured; --, no data]

\begin{tabular}{|c|c|c|c|c|c|}
\hline \multirow{2}{*}{$\begin{array}{c}\text { Depth } \\
\text { of } \\
\text { measurement } \\
\text { (ft bls) }\end{array}$} & \multicolumn{2}{|c|}{$\begin{array}{l}\text { Nonpumping } \\
\text { conditions }\end{array}$} & \multicolumn{3}{|c|}{ Pumping conditions } \\
\hline & $\begin{array}{c}\text { Flow } \\
\text { rate } \\
\text { (gal/min) }\end{array}$ & $\begin{array}{c}\text { Flow } \\
\text { direction }\end{array}$ & $\begin{array}{c}\text { Flow } \\
\text { rate } \\
\text { (gal/min) }\end{array}$ & $\begin{array}{c}\text { Flow } \\
\text { direction }\end{array}$ & $\begin{array}{c}\text { Pumping } \\
\text { rate } \\
\text { (gal/min) }\end{array}$ \\
\hline 48 & $\mathrm{NF}$ & -- & - & -- & -- \\
\hline 52 & NF & -- & -- & -- & -- \\
\hline 62 & NF & -- & 1.33 & up & 0.80 \\
\hline 74 & NF & -- & .63 & up & .81 \\
\hline
\end{tabular}

Table 14. Depth and orientation of bedding, fracture, and water-bearing features interpreted from the acousticteleviewer log and borehole video survey for well MG-1147 (T-11), North Penn Area 7 Superfund site, Upper Gwynedd Township, Montgomery County, Pa.

[ft bls, feet below land surface; Orientations: N, north; E, east; S; south, W; west; Feature type abbreviations: B, bedding plane; F, fracture; WB, water-bearing opening; water-bearing features are shown in bold typeface]

\begin{tabular}{|c|c|c|c|c|}
\hline \multirow{2}{*}{$\begin{array}{c}\text { Feature } \\
\text { depth } \\
\text { (ft bls) }\end{array}$} & \multicolumn{2}{|c|}{ Feature orientation } & \multirow{2}{*}{$\begin{array}{c}\text { Feature } \\
\text { type }\end{array}$} & \multirow[b]{2}{*}{ Borehole video survey observation } \\
\hline & $\begin{array}{c}\text { Strike } \\
\text { (degrees) }\end{array}$ & $\begin{array}{c}\text { Dip } \\
\text { (degrees) }\end{array}$ & & \\
\hline 47.8 & $\mathrm{~N} 44 \mathrm{~W}$ & $17 \mathrm{NE}$ & $\mathrm{F}$ & \\
\hline 49.6 & N $37 \mathrm{E}$ & $21 \mathrm{SE}$ & $\mathrm{F}$ & \\
\hline 50.0 & N $39 \mathrm{E}$ & $15 \mathrm{SE}$ & $\mathrm{F}$ & \\
\hline 54.0 & N $22 \mathrm{~W}$ & $18 \mathrm{NE}$ & $\mathrm{F}$ & Rough at $53 \mathrm{ft}$ bls \\
\hline 54.4 & $\mathrm{~N} 14 \mathrm{~W}$ & $25 \mathrm{NE}$ & $\mathrm{F}$ & \\
\hline 67.8 & N $47 \mathrm{E}$ & $16 \mathrm{SE}$ & F/WB & Opening or high-angle fracture at $66 \mathrm{ft}$ bls \\
\hline 70.6 & N $59 \mathrm{E}$ & $23 \mathrm{SW}$ & $\mathrm{B}$ & \\
\hline 75.2 & N $19 \mathrm{~W}$ & $11 \mathrm{NE}$ & $\mathrm{B}$ & White beds at $76-77 \mathrm{ft}$ bls \\
\hline 81.7 & N 35 W & $22 \mathrm{NE}$ & WB & Rough at $80 \mathrm{ft}$ bls \\
\hline 81.8 & $\mathbf{N} 40 \mathrm{E}$ & $48 \mathrm{SE}$ & WB & \\
\hline
\end{tabular}



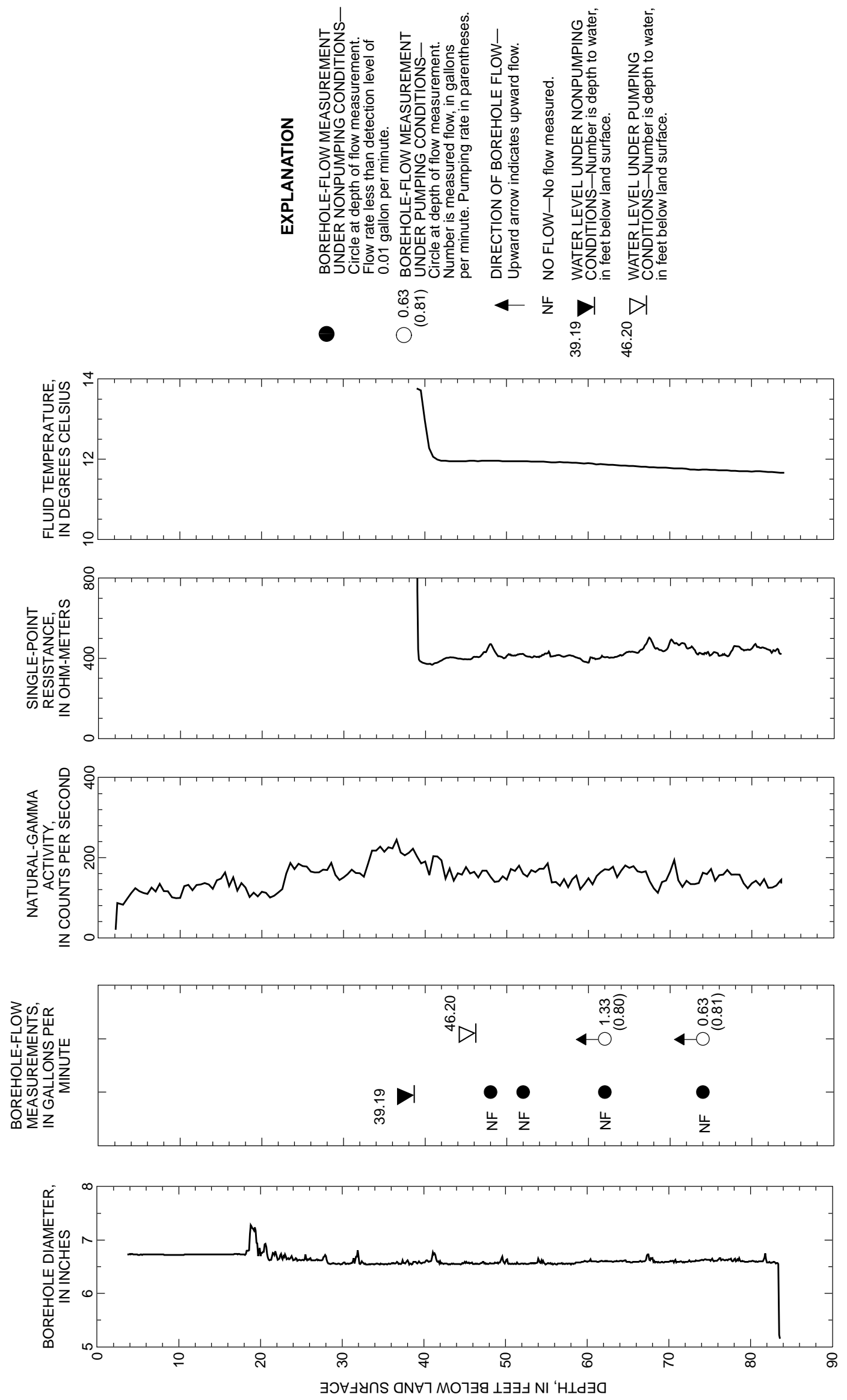


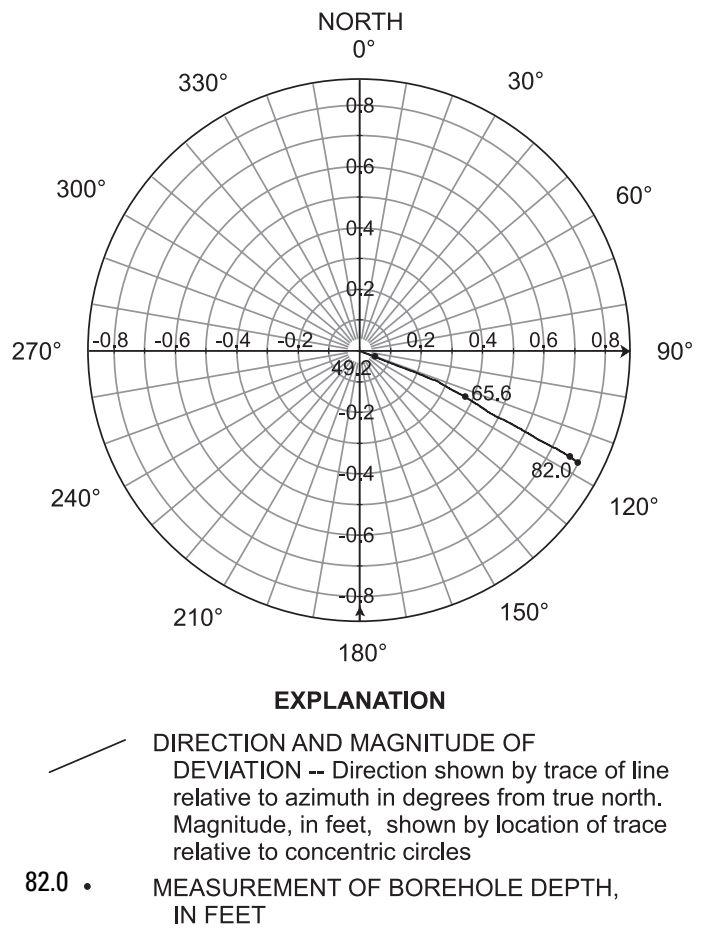

Figure 18. Borehole-deviation log showing direction (in degrees) and magnitude (in feet) of hole deviation from water level to the bottom of the borehole for well MG-1147 (T-11), North Penn Area 7 Superfund site, Upper Gwynedd Township, Montgomery County, Pa.

\section{Well MG-1148 (Teleflex T-12)}

The caliper log shows that the total depth of the borehole is $84 \mathrm{ft}$ and it is cased with 6-in.-diameter plastic casing to about $19 \mathrm{ft}$ bls (fig. 19). The outer surface 8-in. casing material is steel. The caliper log shows that the open borehole is 6 in. in diameter and has numerous fractures throughout. The borehole video shows near-vertical fractures at about 50, 52, 54, 60, 64, 70 , and $81 \mathrm{ft}$ bls.

The natural-gamma log shows elevated counts near $24 \mathrm{ft}$ bls (fig. 19) that may indicate a zone that could be used for lithologic correlation.The natural-gamma and single-pointresistance logs generally have an inverse relation. Slightly elevated single-point-resistance measurements occur in the intervals between 54 and 55 and 59 and $62 \mathrm{ft}$ bls and may indicate sandstone units.

The static water level at the time of logging was $52.48 \mathrm{ft}$ bls. The fluid-temperature log shows a slight increase in temperature from the water level to a depth of about $60 \mathrm{ft}$ bls then little to no change in temperature below that depth (fig. 19). The relatively straight temperature profile is consistent with vertical flow in the borehole, although no flow was detected under nonpumping conditions. Under nonpumping conditions, the heatpulse flowmeter measured no detectable flow at 62, 74, and $80 \mathrm{ft}$ bls (table 15). For measurements of flow under pumping conditions, a submersible pump was placed at $6 \mathrm{ft}$ bls and the well was pumped at rates less than $1 \mathrm{gal} / \mathrm{min}$ (a rate of about $0.7 \mathrm{gal} / \mathrm{min}$ for 10 minutes and then at about $0.45 \mathrm{gal} / \mathrm{min}$ for 23 more minutes). Because the measured upward flow rates are less than measured pumping rates, accuracy of at least one of these rates is questionable. Heatpulse-flowmeter measurements made under pumping conditions indicate that the interval between 80 and $84 \mathrm{ft}$ bls is the most productive. These producing zones correspond to observed fractures at about $82 \mathrm{ft}$ bls on the caliper log. After 33 minutes of pumping, the water level declined $1.90 \mathrm{ft}$ to $54.38 \mathrm{ft}$ bls.

Interpretation of the acoustic-televiewer log (table 16) indicates that a water-bearing fracture intersects the borehole at a relatively low angle ( 8 degrees) at $81 \mathrm{ft}$ bls. This fracture strikes northwest and dips to the southwest. Bedding-plane features also intersect the borehole between 59 and $82 \mathrm{ft}$ bls at relatively shallow angles (from 2 to 37 degrees) and generally appear to strike northwest and dip northeast. During drilling, the borehole deviated from vertical about $0.15 \mathrm{ft}$ to the southeast, as determined from the deviation log (fig. 20). 

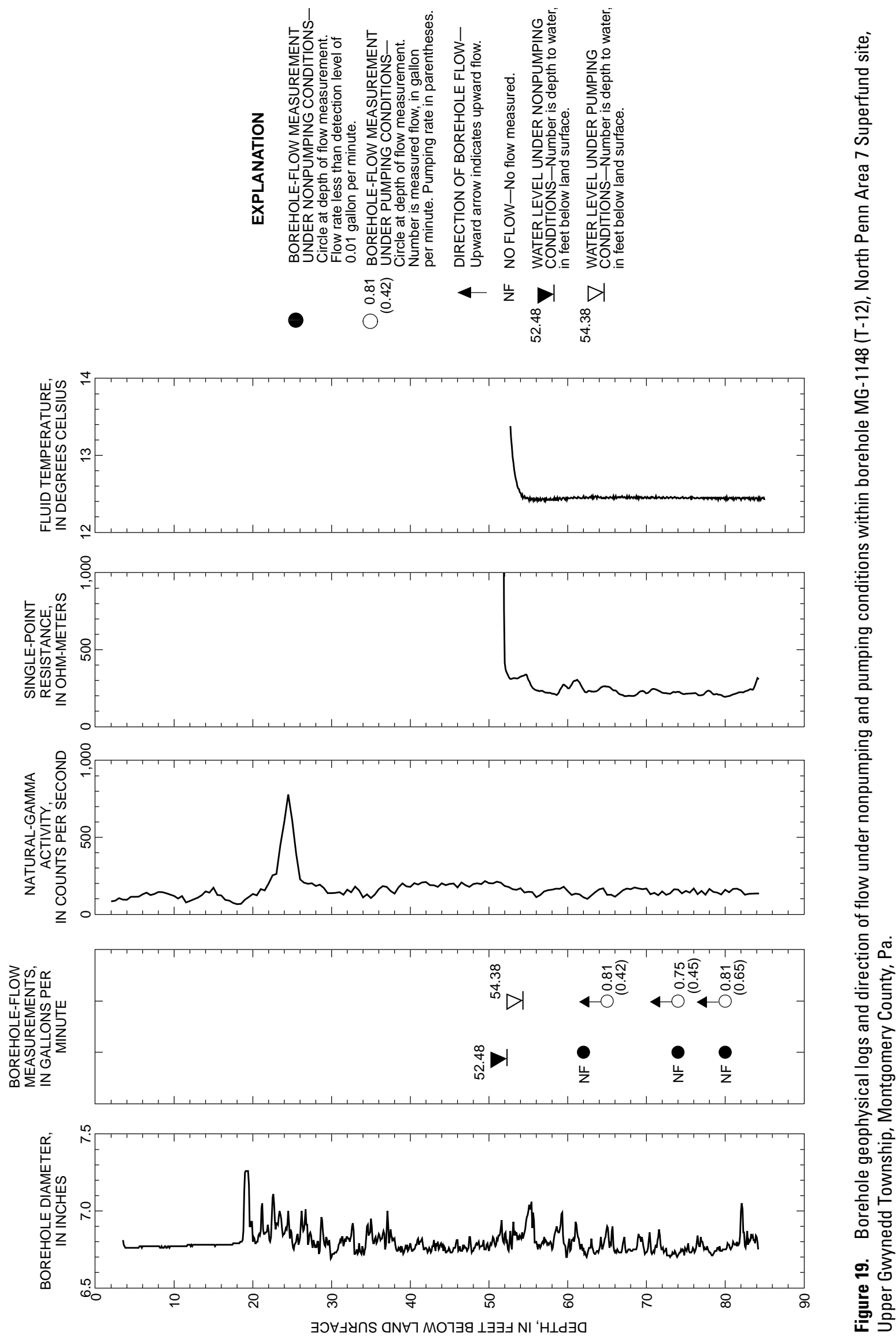
Table 15. Depths, flow rates, flow directions, and pumping rates of heatpulse-flowmeter measurements, under nonpumping and pumping conditions, for well MG-1148 (T-12), North Penn Area 7 Superfund site, Upper Gwynedd Township, Montgomery County, $\mathrm{Pa}$.

[ft bls, feet below land surface; gal/min, gallon per minute; NF, no flow measured; --, no data]

\begin{tabular}{|c|c|c|c|c|c|}
\hline \multirow{2}{*}{$\begin{array}{c}\text { Depth } \\
\text { of } \\
\text { measurement } \\
\text { (ft bls) }\end{array}$} & \multicolumn{2}{|c|}{$\begin{array}{l}\text { Nonpumping } \\
\text { conditions }\end{array}$} & \multicolumn{3}{|c|}{ Pumping conditions } \\
\hline & $\begin{array}{c}\text { Flow } \\
\text { rate } \\
\text { (gal/min) }\end{array}$ & $\begin{array}{c}\text { Flow } \\
\text { direction }\end{array}$ & $\begin{array}{c}\text { Flow } \\
\text { rate } \\
\text { (gal/min) }\end{array}$ & $\begin{array}{c}\text { Flow } \\
\text { direction }\end{array}$ & $\begin{array}{l}\text { Pumping } \\
\text { rate } \\
\text { (gal/min) }\end{array}$ \\
\hline 62 & $\mathrm{NF}$ & $\mathrm{NF}$ & -- & -- & -- \\
\hline 65 & -- & -- & 0.81 & up & 0.42 \\
\hline 74 & NF & NF & .75 & up & .45 \\
\hline 80 & NF & NF & .81 & up & .65 \\
\hline
\end{tabular}

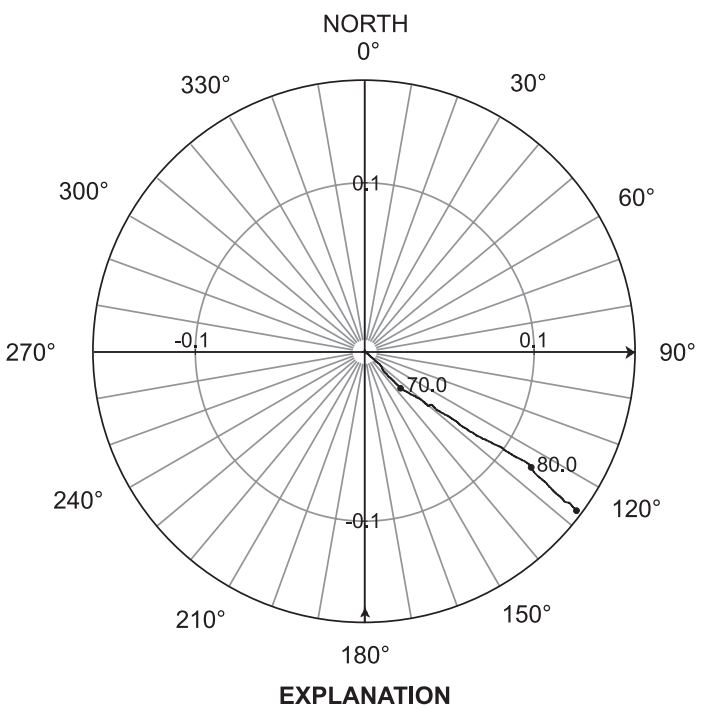

\section{DIRECTION AND MAGNITUDE OF} DEVIATION -- Direction shown by trace of line relative to azimuth in degrees from true north. Magnitude, in feet, shown by location of trace relative to concentric circles

80.0 MEASUREMENT OF BOREHOLE DEPTH, IN FEET

Figure 20. Borehole-deviation log showing direction (in degrees) and magnitude (in feet) of hole deviation from water level to the bottom of the borehole for well MG-1148 (T-12), North Penn Area 7 Superfund site, Upper Gwynedd Township, Montgomery County, $\mathrm{Pa}$.

Table 16. Depth and orientation of bedding, fracture, and water-bearing features interpreted from the acoustic-televiewer log and borehole video survey for well MG-1148 (T-12), North Penn Area 7 Superfund site, Upper Gwynedd Township, Montgomery County, Pa.

[ft bls, feet below land surface; Orientations: N, north; E, east; S; south, W; west; Feature type abbreviations: B, bedding plane; F, fracture; WB, waterbearing opening; water-bearing features are shown in bold typeface]

\begin{tabular}{|c|c|c|c|c|}
\hline \multirow{2}{*}{$\begin{array}{c}\text { Feature } \\
\text { depth } \\
\text { (ft bls) }\end{array}$} & \multicolumn{2}{|c|}{ Feature orientation } & \multirow[b]{2}{*}{$\begin{array}{c}\text { Feature } \\
\text { type }\end{array}$} & \multirow[b]{2}{*}{ Borehole video survey observation } \\
\hline & $\begin{array}{c}\text { Strike } \\
\text { (degrees) }\end{array}$ & $\begin{array}{c}\text { Dip } \\
\text { (degrees) }\end{array}$ & & \\
\hline 58.7 & $\mathrm{~N} 73 \mathrm{~W}$ & $37 \mathrm{NE}$ & B & \\
\hline 59.3 & N $86 \mathrm{~W}$ & $21 \mathrm{NE}$ & $\mathrm{B}$ & \\
\hline 67.0 & N $62 \mathrm{~W}$ & $10 \mathrm{NE}$ & $\mathrm{B}$ & Low-angle fracture at $67 \mathrm{ft}$ bls \\
\hline 74.1 & N $84 \mathrm{~W}$ & $8 \mathrm{NE}$ & $\mathrm{B}$ & \\
\hline 74.5 & $\mathrm{~N} 13 \mathrm{~W}$ & $10 \mathrm{NE}$ & $\mathrm{B}$ & \\
\hline 75.7 & N $54 \mathrm{~W}$ & $18 \mathrm{NE}$ & B & \\
\hline 76.4 & $\mathrm{~N} 43 \mathrm{~W}$ & $6 \mathrm{NE}$ & B & \\
\hline 81.2 & N 42 W & 8 SW & F/WB & Rough, filled high-angle fractures at $81 \mathrm{ft}$ bls \\
\hline 81.6 & N $69 \mathrm{~W}$ & $2 \mathrm{NE}$ & $\mathrm{B}$ & \\
\hline 82.1 & $\mathrm{~N} 44 \mathrm{~W}$ & $13 \mathrm{NE}$ & $\mathrm{B}$ & \\
\hline
\end{tabular}




\section{Well MG-1149 (Teleflex T-10)}

The caliper log shows that the total depth of the borehole is $84 \mathrm{ft}$ and it is cased with 6-in.-diameter plastic casing to about $18.5 \mathrm{ft}$ bls (fig. 21). The outer surface 8 -in. casing material is steel. The caliper log shows that the open borehole is 6 in. in diameter. There are numerous minor fractures throughout the borehole and a major fracture at $68-70 \mathrm{ft}$ bls. The borehole video shows a possible water-bearing near-vertical fracture and opening at $68 \mathrm{ft}$ bls and other near-vertical fractures at $43,51,53,57,66$, and $81 \mathrm{ft}$ bls.

The natural-gamma and single-point-resistance logs generally have an inverse relation. For example, the naturalgamma log shows slightly depressed counts in the interval between 54 and $70 \mathrm{ft}$ bls that correspond to elevated singlepoint-resistance measurements in a similar interval (fig. 21). Elevated single-point-resistance measurements in the interval 53-68 ft bls may indicate sandstone units.

The static water level at the time of logging was $51.13 \mathrm{ft}$ bls. The fluid-temperature log shows that temperature increases slightly from the water level to a depth of about $58 \mathrm{ft}$ bls then changes little below that depth until about $80 \mathrm{ft}$ where it starts to increase again. The relatively straight temperature profile is consistent with vertical flow in the borehole. Under nonpumping conditions, the heatpulse flowmeter measured downward flow at 62, 76, and $80 \mathrm{ft}$ bls (table 17). These measurements (table 17) indicate that, under nonpumping conditions, water probably enters the borehole in the intervals between 51 and 62 and 62 and $76 \mathrm{ft}$ bls and primarily exits the borehole at the intervals between 80 and $84 \mathrm{ft}$ bls. These waterbearing zones correspond to observed fractures at 50-55, 6772 , and $81-82 \mathrm{ft}$ bls on the caliper $\log$. The fractures at 50-55 and 68-72 ft bls are the top and bottom of an interval of elevated single-point-resistance readings possibly associated with sandstone units. For measurements of flow under pumping conditions, a submersible pump was placed at $55 \mathrm{ft}$ bls and the well was pumped at a rate of about $0.9 \mathrm{gal} / \mathrm{min}$. Heatpulseflowmeter measurements made under pumping conditions are inconclusive, although the entire suite of logs indicate that the interval between 80 and $84 \mathrm{ft}$ bls probably is the most produc- tive. This producing zone corresponds to observed fractures at 81-82 ft bls on the caliper log. After 24 minutes of pumping at about $0.9 \mathrm{gal} / \mathrm{min}$, the water level declined to $51.30 \mathrm{ft}$ bls.

Table 17. Depths, flow rates, flow directions, and pumping rates of heatpulse-flowmeter measurements, under nonpumping and pumping conditions, for well MG-1149 (T-10), North Penn Area 7 Superfund site, Upper Gwynedd Township, Montgomery County, $\mathrm{Pa}$.

[ft bls, feet below land surface; gal/min, gallons per minute; --, no data; $>$ UDL, greater than upper detection limit; ?, indicates uncertainty]

\begin{tabular}{ccccccc}
\hline $\begin{array}{c}\text { Depth } \\
\text { of } \\
\begin{array}{c}\text { measurement } \\
\text { (ft bls) }\end{array}\end{array}$ & \multicolumn{2}{c}{$\begin{array}{c}\text { Nonpumping } \\
\text { conditions }\end{array}$} & & \multicolumn{3}{c}{ Pumping conditions } \\
\cline { 2 - 3 } \cline { 6 - 7 } & $\begin{array}{c}\text { Flow } \\
\text { rate } \\
\text { (gal/min) }\end{array}$ & $\begin{array}{c}\text { Flow } \\
\text { direction }\end{array}$ & & $\begin{array}{c}\text { Flow } \\
\text { rate } \\
\text { (gal/min) }\end{array}$ & $\begin{array}{c}\text { Flow } \\
\text { direction }\end{array}$ & $\begin{array}{c}\text { Pumping } \\
\text { rate } \\
\text { (gal/min) }\end{array}$ \\
\hline 62 & 0.2 & down & & 1.05 & up & 0.91 \\
73 & -- & -- & & $>$ UDL & up? & .91 \\
76 & .7 & down & & -- & -- & -- \\
80 & .7 & down & -- & -- & -- \\
\hline
\end{tabular}

Interpretation of the acoustic-televiewer logs (table 18) indicates that possible water-bearing fractures intersect the borehole at relatively moderate to moderately high angles (from 35 to 64 degrees). At the time of geophysical logging, water-producing zones were associated with moderate to highangle fractures at about 66-69 ft bls that strike northwest, dipping northeast, and northeast, dipping northwest or southeast, respectively. A water-receiving zone is associated with a moderate-angle feature at $81 \mathrm{ft}$ bls that strikes northeast and dips southeast. Other fractures and bedding-plane features also intersect the borehole at relatively shallow to moderate angles (from 11 to 64 degrees) between 57 and $77 \mathrm{ft}$ bls. Many of these features appear to strike northwest and dip mostly southwest. A few fractures or bedding-plane features strike northeast and dip either northwest or southeast. During drilling, the borehole deviated from vertical about $0.15 \mathrm{ft}$ to the northeast, as determined from the deviation log (fig. 22). 

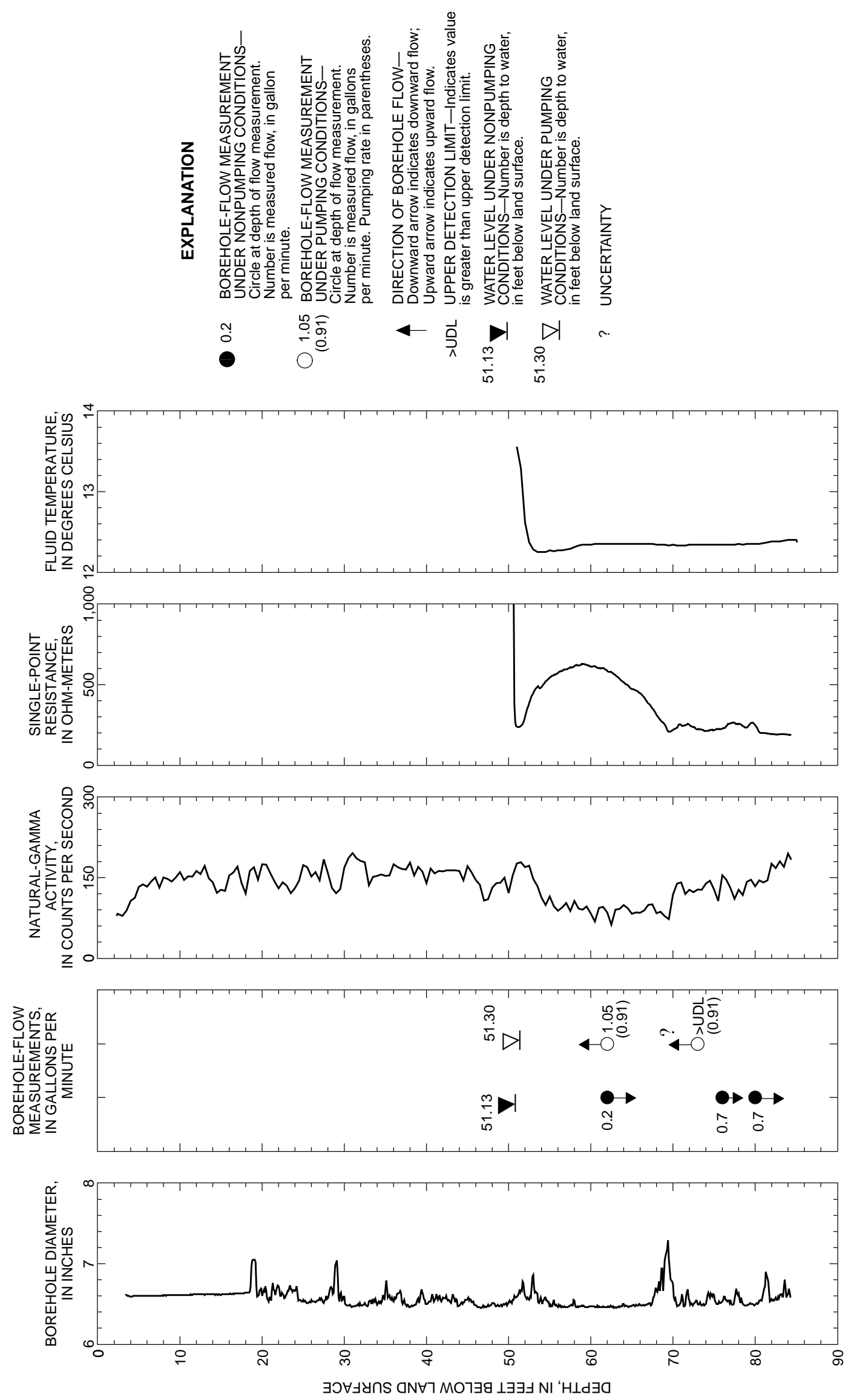

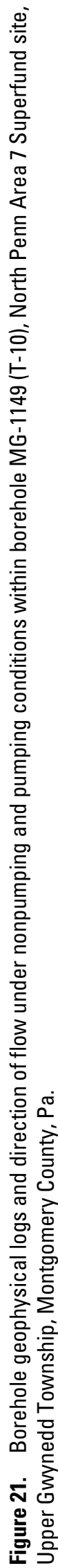


Table 18. Depth and orientation of bedding, fracture, and water-bearing features interpreted from the acousticteleviewer log and borehole video survey for well MG-1149 (T-10), North Penn Area 7 Superfund site, Upper Gwynedd Township, Montgomery County, Pa.

[ft bls, feet below land surface; Orientations: N, north; E, east; S; south, W; west; --, not determined; Feature type abbreviations: B, bedding plane; F, fracture; WB, water-bearing opening; water-bearing features are shown in bold typeface]

\begin{tabular}{|c|c|c|c|c|}
\hline \multirow{2}{*}{$\begin{array}{l}\text { Feature depth } \\
\qquad \text { (ft bls) }\end{array}$} & \multicolumn{2}{|c|}{ Feature orientation } & \multirow[b]{2}{*}{ Feature type } & \multirow[b]{2}{*}{ Borehole video survey observation } \\
\hline & $\begin{array}{c}\text { Strike } \\
\text { (degrees) }\end{array}$ & $\begin{array}{c}\text { Dip } \\
\text { (degrees) }\end{array}$ & & \\
\hline 51 & -- & -- & F/WB & High-angle fracture \\
\hline 53 & -- & -- & F/WB & High-angle fractures \\
\hline 56.9 & N $79 \mathrm{~W}$ & $64 \mathrm{SW}$ & $\mathrm{F}$ & High-angle fracture at $57 \mathrm{ft}$ bls \\
\hline 59.4 & $\mathrm{~N} 46 \mathrm{~W}$ & $55 \mathrm{SW}$ & $\mathrm{F}$ & \\
\hline 59.4 & N $34 \mathrm{~W}$ & $56 \mathrm{NE}$ & $\mathrm{F}$ & \\
\hline 63.0 & N $69 \mathrm{~W}$ & $26 \mathrm{SW}$ & $\mathrm{F}$ & Moderate-angle fracture at $63 \mathrm{ft}$ bls \\
\hline 63.4 & $\mathrm{~N} 45 \mathrm{~W}$ & $21 \mathrm{SW}$ & $\mathrm{F}$ & \\
\hline 66.7 & N 74 E & $82 \mathrm{SE}$ & F/WB & High-angle fracture at 66-68 ft bls \\
\hline 67.1 & N $20 \mathrm{~W}$ & $64 \mathrm{NE}$ & F/WB & \\
\hline 67.2 & N 77 W & $64 \mathrm{NE}$ & F/WB & \\
\hline 68 & -- & -- & F/WB & High-angle fracture at $68 \mathrm{ft}$ bls \\
\hline 69.1 & N 18 E & 35 NW & F/WB & \\
\hline 73.4 & N $19 \mathrm{~W}$ & $48 \mathrm{SW}$ & $\mathrm{F}$ & Low-angle fracture at $73 \mathrm{ft}$ bls \\
\hline 75.5 & N $31 \mathrm{~W}$ & $18 \mathrm{SW}$ & $\mathrm{F}$ & \\
\hline 76.5 & $\mathrm{~N} 4 \mathrm{~W}$ & $12 \mathrm{SW}$ & $\mathrm{B}$ & Low-angle fracture at $76 \mathrm{ft}$ bls \\
\hline 77.0 & N $58 \mathrm{E}$ & $42 \mathrm{NW}$ & $\mathrm{F}$ & \\
\hline 80.9 & N $18 \mathrm{E}$ & $40 \mathrm{SE}$ & WR & Rough, high-angle fracture at $81 \mathrm{ft}$ bls \\
\hline
\end{tabular}

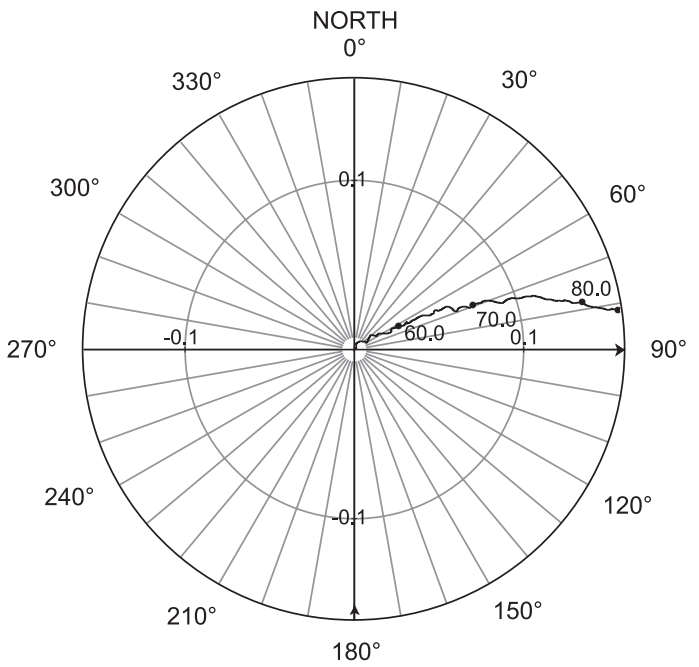

EXPLANATION

DIRECTION AND MAGNITUDE OF DEVIATION -- Direction shown by trace of line relative to azimuth in degrees from true north. Magnitude, in feet, shown by location of trace relative to concentric circles

80.0 - MEASUREMENT OF BOREHOLE DEPTH, IN FEET
Figure 22. Borehole-deviation log showing direction (in degrees) and magnitude (in feet) of hole deviation from water level to the bottom of the borehole for well MG-1149 (T-10), North Penn Area 7 Superfund site, Upper Gwynedd Township, Montgomery County, $\mathrm{Pa}$. 


\section{Well MG-1505 (Huey)}

The caliper log shows that the total depth of the borehole is $83.2 \mathrm{ft}$ and it is cased with 6-in.-diameter casing to about $16 \mathrm{ft}$ bls (fig. 23). The casing material is steel. The open borehole is 6 in. in diameter. There are numerous minor fractures throughout the borehole and major fractures at 48-50, 56-58, 71-73, and 80-83 ft bls. No borehole video log was collected for this well.

The natural-gamma and single-point-resistance logs generally have an inverse relation. For example, the naturalgamma log shows slightly depressed counts at 61, 66, and 69$71 \mathrm{ft}$ bls that correspond to elevated single-point-resistance measurements at similar depths (fig. 23). Slightly elevated single-point-resistance measurements may indicate sandstone units.

The static water level at the time of logging was about $25.94 \mathrm{ft}$ bls. The fluid-temperature log shows that temperature decreases with depth from the water level to a depth of about $46 \mathrm{ft}$ bls and changes little below that depth (fig. 23). The relatively straight temperature profile is consistent with vertical flow in the borehole. Under nonpumping conditions, the heatpulse flowmeter measured no detectable flow at $38 \mathrm{ft}$ bls and upward flow at 29, 52, 63, 70, and $76 \mathrm{ft}$ bls (table 19). These measurements (table 19) indicate that, under nonpumping conditions, water probably enters the borehole in the intervals between 29 and 38 and 76 and $83.5 \mathrm{ft}$ bls and exits the borehole at the intervals between 26 and 29, 38 and 52, 52 and 63, 63 and 70 , and 70 and $76 \mathrm{ft}$ bls. These water-bearing zones correspond to observed fractures at 26-28, 30-32, 48-50, 56-58, 7173 , and $80-83 \mathrm{ft}$ bls on the caliper log. For measurements of flow under pumping conditions, a submersible pump was placed at $35 \mathrm{ft}$ bls, and the well was pumped at rates of $0.5 \mathrm{gal} / \mathrm{min}$ for $15 \mathrm{minutes}, 1.2 \mathrm{gal} / \mathrm{min}$ for 5 minutes, and then about $2.3 \mathrm{gal} / \mathrm{min}$ for 26 minutes. After 46 minutes of pumping, the water level declined $3.26 \mathrm{ft}$ to about $29.2 \mathrm{ft}$ bls. Heatpulse-flowmeter measurements made under pumping conditions indicate that the intervals between 26 and 38 and 76 and $83.5 \mathrm{ft}$ bls are the most productive. These producing zones probably correspond to observed fractures at 30-32 and 80$83 \mathrm{ft}$ bls on the caliper log.

Table 19. Depths, flow rates, flow directions, and pumping rates of heatpulse-flowmeter measurements, under nonpumping and pumping conditions, for well MG-1505 (Huey), North Penn Area 7 Superfund site, Upper Gwynedd Township, Montgomery County, $\mathrm{Pa}$

[ft bls, feet below land surface; gal/min, gallons per minute; NF, no flow measured; >, greater than; --, no data]

\begin{tabular}{ccccccc}
\hline $\begin{array}{c}\text { Depth } \\
\text { of } \\
\begin{array}{c}\text { measurement } \\
\text { (ft bls) }\end{array}\end{array}$ & \multicolumn{2}{c}{$\begin{array}{c}\text { Nonpumping } \\
\text { conditions }\end{array}$} & & \multicolumn{3}{c}{ Pumping conditions } \\
\cline { 2 - 3 } \cline { 5 - 7 } & $\begin{array}{c}\text { Flow } \\
\text { rate } \\
\text { (gal/min) }\end{array}$ & $\begin{array}{c}\text { Flow } \\
\text { direction }\end{array}$ & & $\begin{array}{c}\text { Flow } \\
\text { rate } \\
\text { (gal/min) }\end{array}$ & $\begin{array}{c}\text { Flow } \\
\text { direction }\end{array}$ & $\begin{array}{c}\text { Pumping } \\
\text { rate } \\
\text { (gal/min) }\end{array}$ \\
\hline 29 & 0.1 & up & -- & -- & -- \\
38 & NF & NF & & -- & -- & -- \\
39 & -- & -- & & 0.62 & up & 2.28 \\
52 & .2 & up & & -- & -- & -- \\
53 & -- & -- & $0.66->1.0$ & up & 2.29 \\
63 & .4 & up & & -- & -- & -- \\
70 & $.6-.7$ & up & & -- & -- & -- \\
76 & $.7-1.0$ & up & -- & -- & -- \\
\hline
\end{tabular}



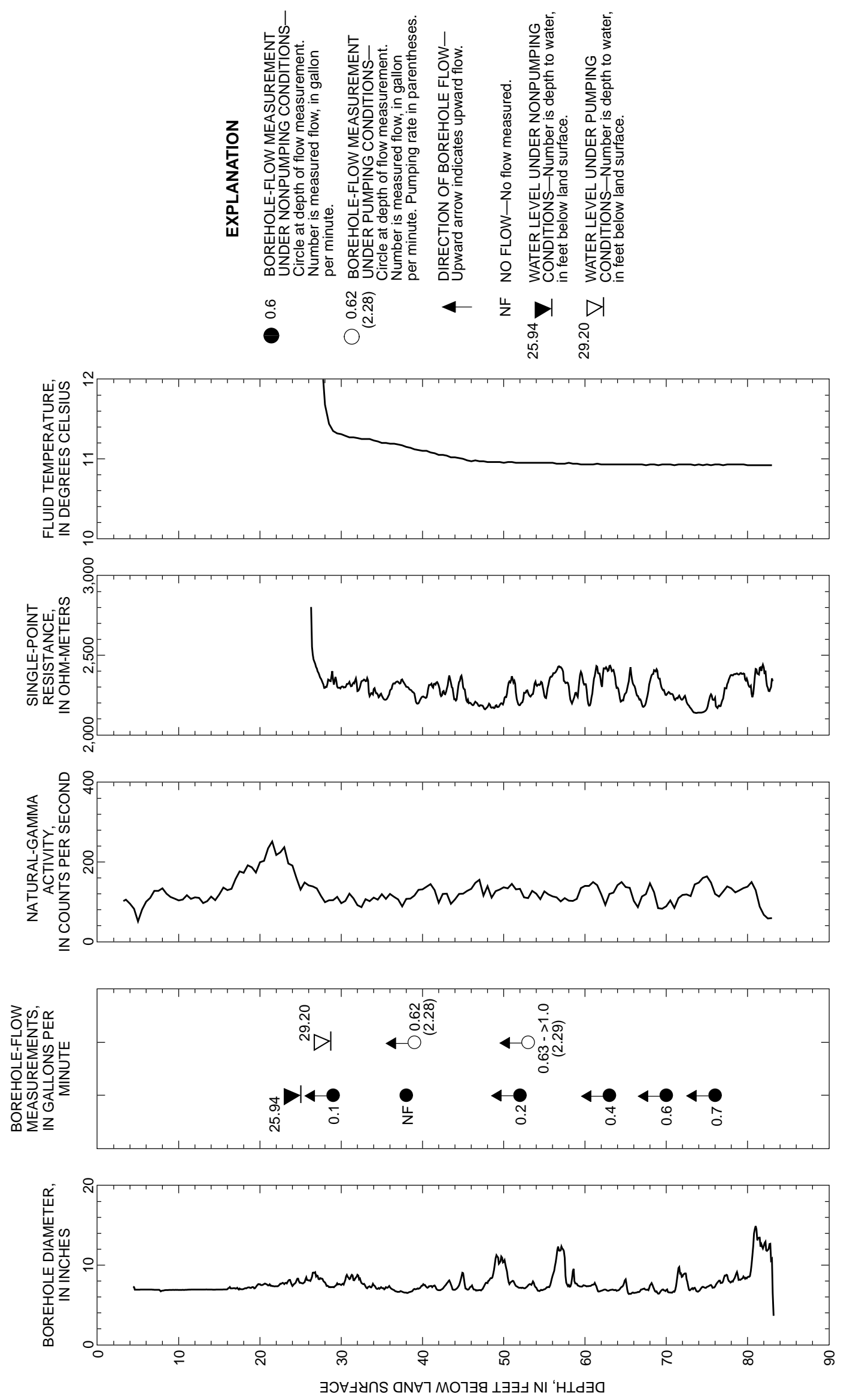


\section{Well MG-1842 (Teleflex T-15)}

The caliper log shows that the total depth of the borehole is $86 \mathrm{ft}$ and it is cased with 6-in.-diameter casing to about $18 \mathrm{ft}$ bls (fig. 24). The casing material is plastic. The caliper $\log$ shows that the open borehole is 6 in. in diameter. There are a few minor fractures throughout the borehole and a major fracture at $48-51 \mathrm{ft}$ bls. The borehole video shows a possible water-bearing near-vertical fracture at 48-51 ft bls and other near-vertical fractures at 43, 72, and $81 \mathrm{ft}$ bls.

The natural-gamma and single-point-resistance logs commonly have an inverse relation. For example, the naturalgamma log shows slightly elevated counts at $61 \mathrm{ft}$ bls that correspond to slightly depressed single-point-resistance measurements at a similar depth (fig. 24). Slightly elevated singlepoint-resistance measurements, such as that at $82 \mathrm{ft}$ bls, may indicate sandstone units.

The static water level at the time of logging was $41.18 \mathrm{ft}$ bls. The fluid-temperature log shows that temperature decreases slightly with depth below $49 \mathrm{ft}$ bls, where there is an inflection. The relatively straight temperature profile is consistent with vertical flow in the borehole, although flow was not detected under nonpumping conditions except near the bottom of the hole. Under nonpumping conditions, the heatpulse flowmeter measured no detectable flow at 46, 54, and $66 \mathrm{ft}$ bls and downward flow at $78 \mathrm{ft}$ bls (table 20). These measurements (table 20) indicate that, under nonpumping conditions, water probably enters the borehole in the interval between 66 and $78 \mathrm{ft}$ bls and primarily exits the borehole at the interval between 78 and $86 \mathrm{ft}$ bls. These water-bearing zones correspond to observed fractures at 73.5 and $82 \mathrm{ft}$ bls on the caliper log. For measurements of flow under pumping conditions, a submersible pump was placed at $46 \mathrm{ft}$ bls, and the well was pumped at a rate of about $1.1 \mathrm{gal} / \mathrm{min}$. Heatpulse-flowmeter measurements made under pumping conditions indicate that the largest quantity of water is produced from the interval between 78 and $86 \mathrm{ft}$ bls and lessor amounts are produced from the intervals between 66 and 78, 66 and 54, and above $54 \mathrm{ft}$ bls. These producing zones correspond to observed fractures at 81 $82,73-74,57-59$, and 48-51 ft bls on the caliper log. The fractures at 81-82 ft bls are near possible sandstone units indicated by elevated single-point-resistance measurements. After 27 minutes of pumping at about $1.1 \mathrm{gal} / \mathrm{min}$, the water level declined $0.28 \mathrm{ft}$ to $41.46 \mathrm{ft}$ bls.

Table 20. Depths, flow rates, flow directions, and pumping rates of heatpulse-flowmeter measurements, under nonpumping and pumping conditions, for well MG-1842 (T-15), North Penn Area 7 Superfund site, Upper Gwynedd Township, Montgomery County, $\mathrm{Pa}$.

[ft bls, feet below land surface; gal/min, gallons per minute; NF, no flow measured; --, no data]

\begin{tabular}{|c|c|c|c|c|c|}
\hline \multirow{2}{*}{$\begin{array}{c}\text { Depth } \\
\text { of } \\
\text { measurement } \\
\text { (ft bls) }\end{array}$} & \multicolumn{2}{|c|}{$\begin{array}{c}\text { Nonpumping } \\
\text { conditions }\end{array}$} & \multicolumn{3}{|c|}{ Pumping conditions } \\
\hline & $\begin{array}{c}\text { Flow } \\
\text { rate } \\
\text { (gal/min) }\end{array}$ & $\begin{array}{c}\text { Flow } \\
\text { direction }\end{array}$ & $\begin{array}{c}\text { Flow } \\
\text { rate } \\
\text { (gal/min) }\end{array}$ & $\begin{array}{c}\text { Flow } \\
\text { direction }\end{array}$ & $\begin{array}{c}\text { Pumping } \\
\text { rate } \\
\text { (gal/min) }\end{array}$ \\
\hline 46 & $\mathrm{NF}$ & $\mathrm{NF}$ & -- & -- & -- \\
\hline 54 & $\mathrm{NF}$ & $\mathrm{NF}$ & 0.88 & up & 1.08 \\
\hline 66 & $\mathrm{NF}$ & $\mathrm{NF}$ & .81 & up & 1.08 \\
\hline 78 & 1.0 & down & .65 & up & 1.1 \\
\hline
\end{tabular}

Interpretation of the acoustic-televiewer log (table 21) indicates that possible water-bearing fractures intersect the borehole at relatively low to high angles (from 0 to 72 degrees). At the time of geophysical logging, water-producing zones were associated with moderate- to high-angle features at about 73-74 ft bls that strike northeast and dip southeast. A water-receiving zone is associated with an apparently flat-lying feature at about $81 \mathrm{ft}$ bls. Numerous bedding-plane features also intersect the borehole at relatively shallow to moderate angles (from 6 to 25 degrees) between 50 and $79 \mathrm{ft}$ bls. About half of these features appear to strike northeast and dip northwest, and the remainder strike mostly northwest and dip both northeast and southwest. Some moderate to high angle fractures (from 30 to 78 degrees) appear to strike almost due north. During drilling, the borehole deviated from vertical about $0.7 \mathrm{ft}$ to the south, as determined from the deviation log (fig. 25). 

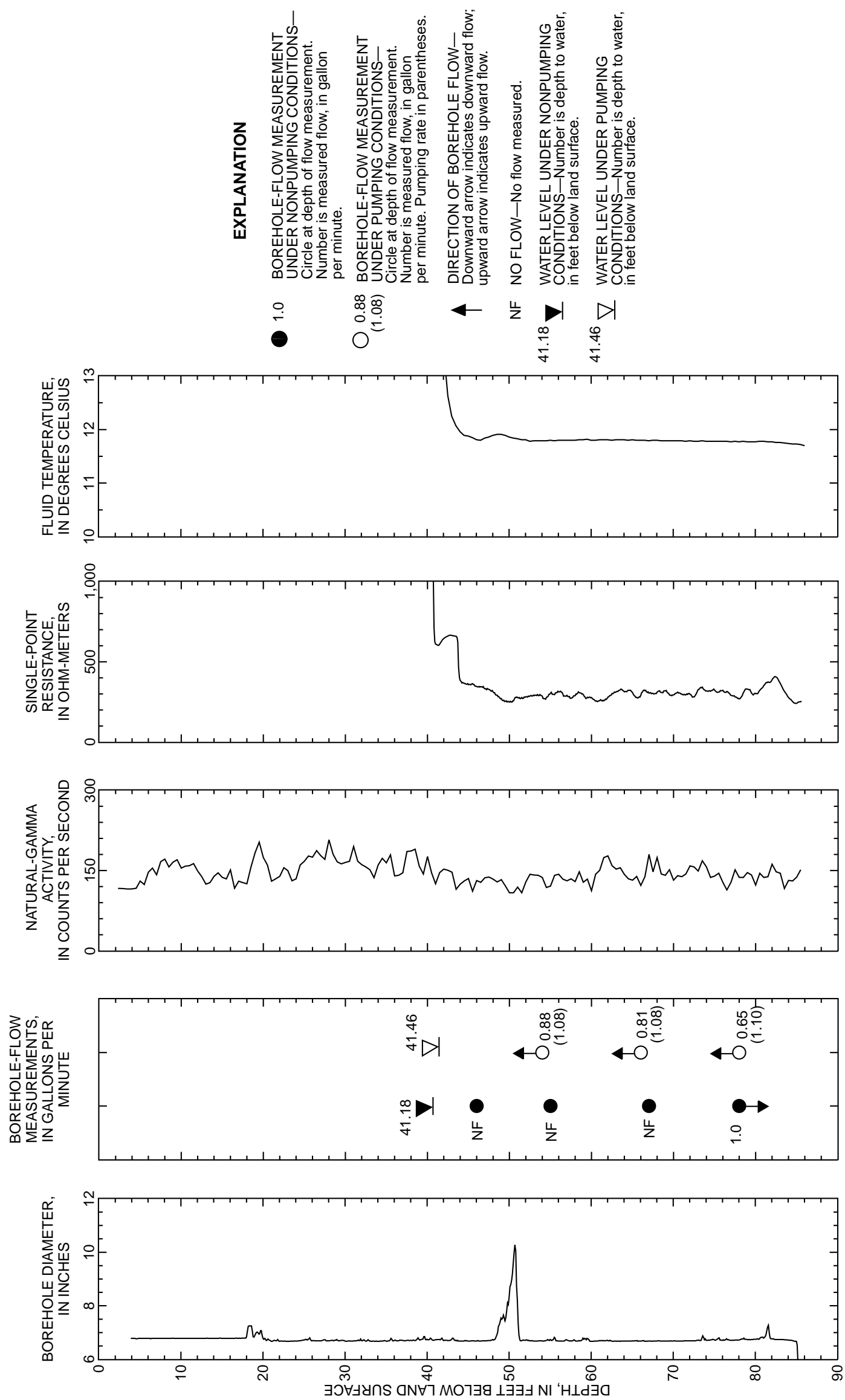
Table 21. Depth and orientation of bedding, fracture, and water-bearing features interpreted from the acousticteleviewer log and borehole video survey for well MG-1842 (T-15), North Penn Area 7 Superfund site, Upper Gwynedd Township, Montgomery County, Pa.

[ft bls, feet below land surface; Orientations: N, north; E, east; S; south, W; west; --, not determined; Feature type abbreviations: B, bedding plane; F, fracture; WB, water-bearing opening; ?, indicates uncertainty in feature type; water-bearing features are shown in bold typeface]

\begin{tabular}{|c|c|c|c|c|}
\hline \multirow{2}{*}{$\begin{array}{c}\text { Feature } \\
\text { depth } \\
\text { (ft bls) }\end{array}$} & \multicolumn{2}{|c|}{ Feature orientation } & \multirow{2}{*}{$\begin{array}{c}\text { Feature } \\
\text { type }\end{array}$} & \multirow[b]{2}{*}{ Borehole video survey observation } \\
\hline & $\begin{array}{c}\text { Strike } \\
\text { (degrees) }\end{array}$ & $\begin{array}{c}\text { Dip } \\
\text { (degrees) }\end{array}$ & & \\
\hline 48 & -- & -- & F/WB & Rough, high-angle fractures at $48-51 \mathrm{ft}$ bls \\
\hline 50.9 & N 5 W & $31 \mathrm{NE}$ & F/WB & \\
\hline 52.3 & N $73 \mathrm{~W}$ & $7 \mathrm{NE}$ & $\mathrm{B}$ & \\
\hline 52.6 & N 33 E & $18 \mathrm{NW}$ & B & \\
\hline 54.6 & $\mathrm{~N} 25 \mathrm{E}$ & $12 \mathrm{NW}$ & B & \\
\hline 54.8 & N $16 \mathrm{E}$ & $16 \mathrm{NW}$ & B & \\
\hline 55.5 & N $7 \mathrm{~W}$ & $9 \mathrm{SW}$ & B & \\
\hline 55.7 & N $6 \mathrm{E}$ & $6 \mathrm{NW}$ & $\mathrm{B}$ & \\
\hline 56.7 & $\mathrm{~N} 4 \mathrm{~W}$ & $18 \mathrm{SW}$ & $\mathrm{B}$ & \\
\hline 56.9 & N $88 \mathrm{E}$ & $25 \mathrm{NW}$ & $\mathrm{B}$ & Low-angle fracture at $57 \mathrm{ft}$ bls \\
\hline 57.8 & $\mathrm{~N} 4 \mathrm{~W}$ & $14 \mathrm{SW}$ & B & \\
\hline 58.8 & $\mathbf{N} 2 \mathbf{E}$ & 44 NW & F/WB? & \\
\hline 59.4 & N $58 \mathrm{E}$ & $16 \mathrm{NW}$ & $\mathrm{B}$ & \\
\hline 59.6 & N $10 \mathrm{~W}$ & $9 \mathrm{SW}$ & B & \\
\hline 60.4 & $\mathrm{~N} 25 \mathrm{E}$ & $11 \mathrm{NW}$ & B & \\
\hline 61.1 & $\mathrm{~N} 4 \mathrm{~W}$ & $7 \mathrm{SW}$ & B & \\
\hline 61.8 & N $9 \mathrm{~W}$ & $64 \mathrm{NE}$ & $\mathrm{F}$ & \\
\hline 70.1 & $\mathrm{~N} 4 \mathrm{E}$ & $78 \mathrm{SE}$ & $\mathrm{F}$ & \\
\hline 71.9 & $\mathrm{~N} 48 \mathrm{~W}$ & $13 \mathrm{NE}$ & B & \\
\hline 73.2 & N 36 E & $37 \mathrm{SE}$ & WP & Rough, high-angle fractures at $72 \mathrm{ft}$ bls \\
\hline 74.1 & N 15 E & $72 \mathrm{SE}$ & WP & \\
\hline 78.4 & $\mathrm{~N} 76 \mathrm{~W}$ & $10 \mathrm{NE}$ & $\mathrm{B}$ & \\
\hline 79.1 & $\mathrm{~N} 77 \mathrm{E}$ & $17 \mathrm{NW}$ & B & \\
\hline 81.4 & N 68 E & 0 NW & F/WB & Rough, high-angle fractures at $81 \mathrm{ft}$ bls \\
\hline
\end{tabular}




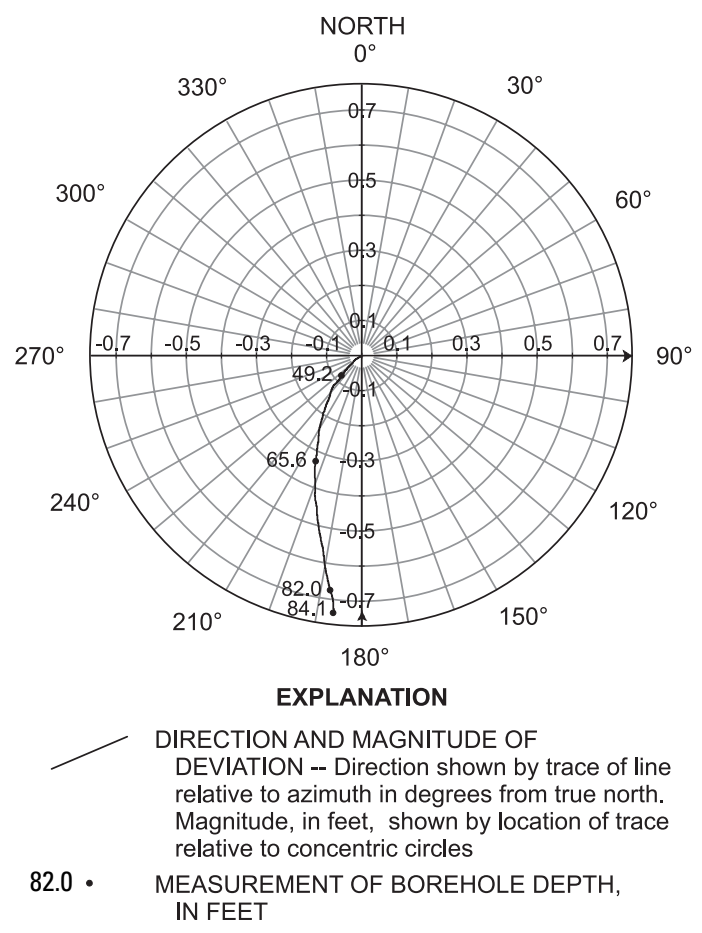

Figure 25. Borehole-deviation log showing direction (in degrees) and magnitude (in feet) of hole deviation from water level to the bottom of the borehole for well MG-1842 (T-15), North Penn Area 7 Superfund site, Upper Gwynedd Township, Montgomery County, Pa.

\section{Well MG-1843 (Teleflex T-6)}

The caliper log shows that the total depth of the borehole is $37.5 \mathrm{ft}$ and it is cased with 6-in.-diameter plastic casing to $18 \mathrm{ft}$ bls (fig. 26). The outer surface 8-in. casing material is steel. The caliper log shows that the open borehole is 6 in. in diameter. There are a few minor fractures throughout the borehole and two relatively major fractures just below the bottom of casing at $19 \mathrm{ft}$ bls and in the interval from 31 to $32 \mathrm{ft} \mathrm{bls}$.

The static water level at the time of logging was $30.3 \mathrm{ft}$ bls. Because water was only in the bottom $6.2 \mathrm{ft}$ of the borehole, the single-point-resistance log is relatively short, and therefore, not especially useful in determining lithology of the hole. Nevertheless, elevated single-point-resistance measurements at $31.5-32.5 \mathrm{ft}$ bls corresponding to depressed naturalgamma measurements at similar depths (fig. 26) may indicate the presence of a sandstone unit.

As with the single-point-resistance log, the fluid-temperature $\log$ describes only the bottom $6.2 \mathrm{ft}$ of the hole. In this short interval, the fluid-temperature log shows that temperature decreases slightly with depth. Measurements of flow were not made because of the small amount of water in the borehole.

\section{Well MG-1844 (Fitzpatrick Container)}

The caliper log shows that the total depth of the borehole is $51.2 \mathrm{ft}$ and it is cased with 6-in.-diameter casing to about $15 \mathrm{ft}$ bls (fig. 27). The casing material is plastic. The caliper $\log$ shows that the open borehole is 6 in. in diameter. There are a few minor fractures throughout the borehole and a relatively major fracture just below the bottom of casing at $15 \mathrm{ft}$ bls. The borehole video shows possible water-bearing near-vertical fractures and openings at 39-44 and $47 \mathrm{ft}$ bls.

The natural-gamma log shows elevated counts at 45$46 \mathrm{ft}$ bls (fig. 27) that might be used for stratigraphic correlation. Because water was only in the bottom $7.2 \mathrm{ft}$ of the hole, the single-point-resistance log is relatively short (compared to other logs) and, therefore, not especially useful in determining lithology of the hole.

The static water level at the time of logging was $44.92 \mathrm{ft}$ bls. As with the single-point-resistance log, the fluidtemperature $\log$ describes only the bottom $7.2 \mathrm{ft}$ of the hole. In this short interval, the fluid-temperature log shows that temperature decreases slightly with depth; there is a small inflection at about $46 \mathrm{ft}$ bls that may indicate the presence of a waterbearing fracture. Under nonpumping conditions, the heatpulse flowmeter measured no detectable vertical flow at $46 \mathrm{ft}$ bls. Measurements of flow were not made under pumping conditions. 


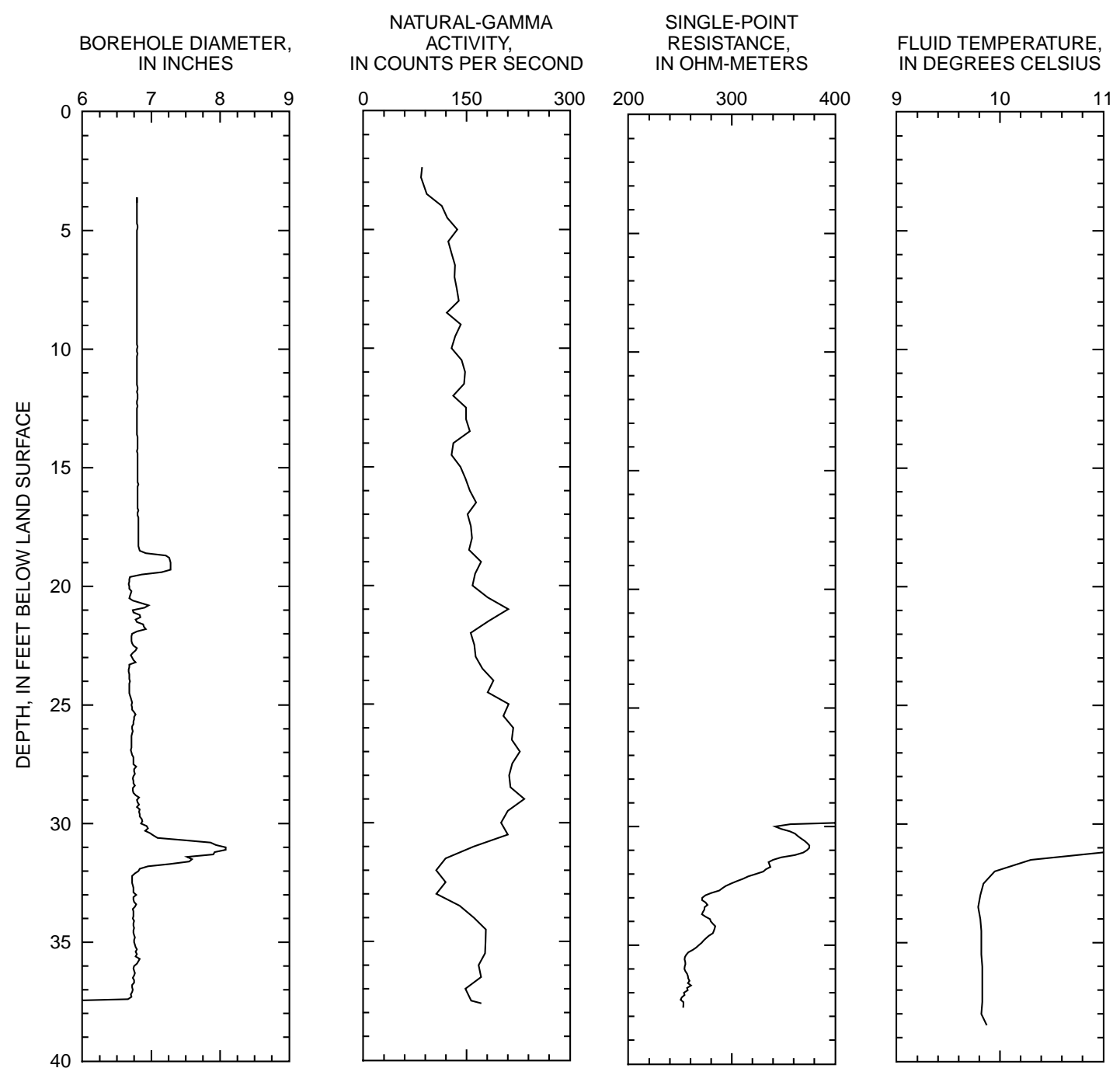

Figure 26. Borehole geophysical logs for borehole MG-1843 (T-6), North Penn Area 7 Superfund site, Upper Gwynedd Township, Montgomery County, Pa. 

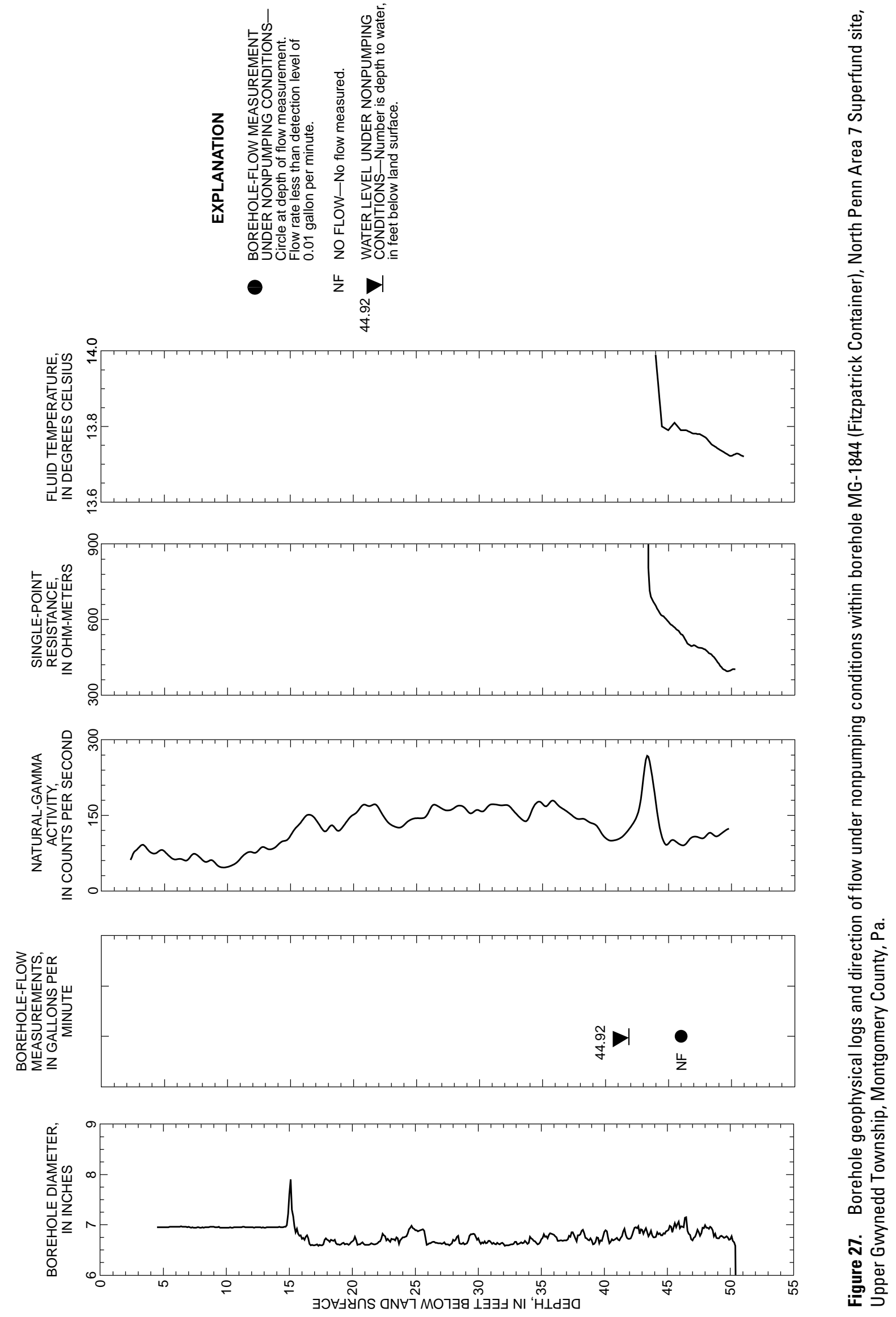


\section{Well MG-1845 (Fitzpatrick Container)}

The caliper log shows that the total depth of the borehole is $54.6 \mathrm{ft}$ and it is cased with 6-in.-diameter casing to about $19 \mathrm{ft}$ bls (fig. 28). The casing material is plastic. The caliper $\log$ shows that the open borehole is 6 in. in diameter. There are a few minor fractures throughout the borehole. The borehole video shows near-horizontal fractures at 45 and $53 \mathrm{ft}$ bls

The natural-gamma log shows elevated counts at 52$53 \mathrm{ft}$ bls (fig. 28) that might be used for stratigraphic correlation. Because water was only in the bottom $9.7 \mathrm{ft}$ of the hole, the single-point-resistance log is short. The single-point-resistance log shows slightly elevated measurements in the interval between 47 and $52 \mathrm{ft}$ bls that may be associated with a sandstone unit.

The static water level at the time of logging was $44.92 \mathrm{ft}$ bls. As with the single-point-resistance log, the fluidtemperature log describes only the bottom $9.7 \mathrm{ft}$ of the hole. In this short interval, the fluid-temperature log shows that temperature increases slightly with depth to $53 \mathrm{ft}$ bls and below that depth changes little. Under nonpumping conditions, the heatpulse flowmeter measured no detectable vertical flow at $49 \mathrm{ft}$ bls, although at that depth, there was possible lateral flow. Measurements of flow were not made under pumping conditions.

\section{Well MG-1846 (Fitzpatrick Container)}

The caliper log shows that the total depth of the borehole is $55.9 \mathrm{ft}$ and it is cased with 6-in.-diameter casing to about $21 \mathrm{ft}$ bls (fig. 29). The casing material is plastic. The caliper $\log$ shows that the open borehole is 6 in. in diameter. There are a few minor fractures throughout the borehole.

The natural-gamma and single-point-resistance logs generally have an inverse relation. For example, the naturalgamma log shows slightly depressed readings at 47,50 , and $52 \mathrm{ft}$ bls that correspond to slightly elevated single-point-resistance readings at similar depths (fig. 29). Slightly elevated single-point-resistance readings may indicate sandstone units. The borehole video shows a lithology change from red- to gray-colored rock at $46 \mathrm{ft}$ bls. Because water was only in the bottom $9.7 \mathrm{ft}$ of the hole, the single-point-resistance log is short.
The static water level at the time of logging was $46.19 \mathrm{ft}$ bls. As with the single-point-resistance log, the fluidtemperature log describes only the bottom $9.7 \mathrm{ft}$ of the hole. In this short interval, the fluid-temperature log shows that temperature changes little. The relatively straight temperature profile is consistent with vertical flow in the borehole, although flow was not detected under nonpumping conditions. Under nonpumping conditions, the heatpulse flowmeter measured no detectable flow at $50 \mathrm{ft}$ bls. Measurements of flow were not made under pumping conditions.

\section{Well MG-1897 (Clearline 3)}

The caliper log shows that the total depth of the open borehole is $288 \mathrm{ft}$ and it is cased with 10-in.-diameter casing to $44 \mathrm{ft}$ bls (fig. 30). Soft mud was encountered at the bottom $8 \mathrm{ft}$ of the borehole. The casing material is steel. The caliper log shows that the open borehole is $10 \mathrm{in}$. in diameter to a depth of about $184 \mathrm{ft}$ bls and 8 in. in diameter below that depth. There are numerous major and minor fractures throughout borehole, including major fractures at 45-47, 53, 60-64, 100, 176-184, 257-260, 264, and 275-278 ft bls. The borehole video shows a possible water-bearing near-vertical fracture and opening at $175 \mathrm{ft}$ bls, other near-vertical fractures at 52, 62, 79, 90, 99, 114,261 , and $273 \mathrm{ft}$ bls, and other near-horizontal fractures at 99, 125, and $231 \mathrm{ft}$ bls.

The natural-gamma and single-point-resistance logs generally have an inverse relation. For example, the naturalgamma log shows slightly depressed counts at 82-85, 111-119, and $178-182 \mathrm{ft}$ bls that correspond to slightly elevated singlepoint-resistance measurements at a similar depths (fig. 30). The single-point-resistance log shows that 4- to 10-ft thick intervals of elevated resistance, probably sandstone units, occur regularly throughout the borehole. The natural-gamma and single-point-resistance logs indicate that lithology probably alternates between shale and sandstone.

The static water level at the time of logging was $24.28 \mathrm{ft}$ bls. The fluid-temperature $\log$ (fig. 30) shows that temperature increases with depth because of geothermal heating. The relatively straight but increasing temperature profile is consistent with little to no vertical flow in the borehole that otherwise might alter the natural geothermal gradient. 


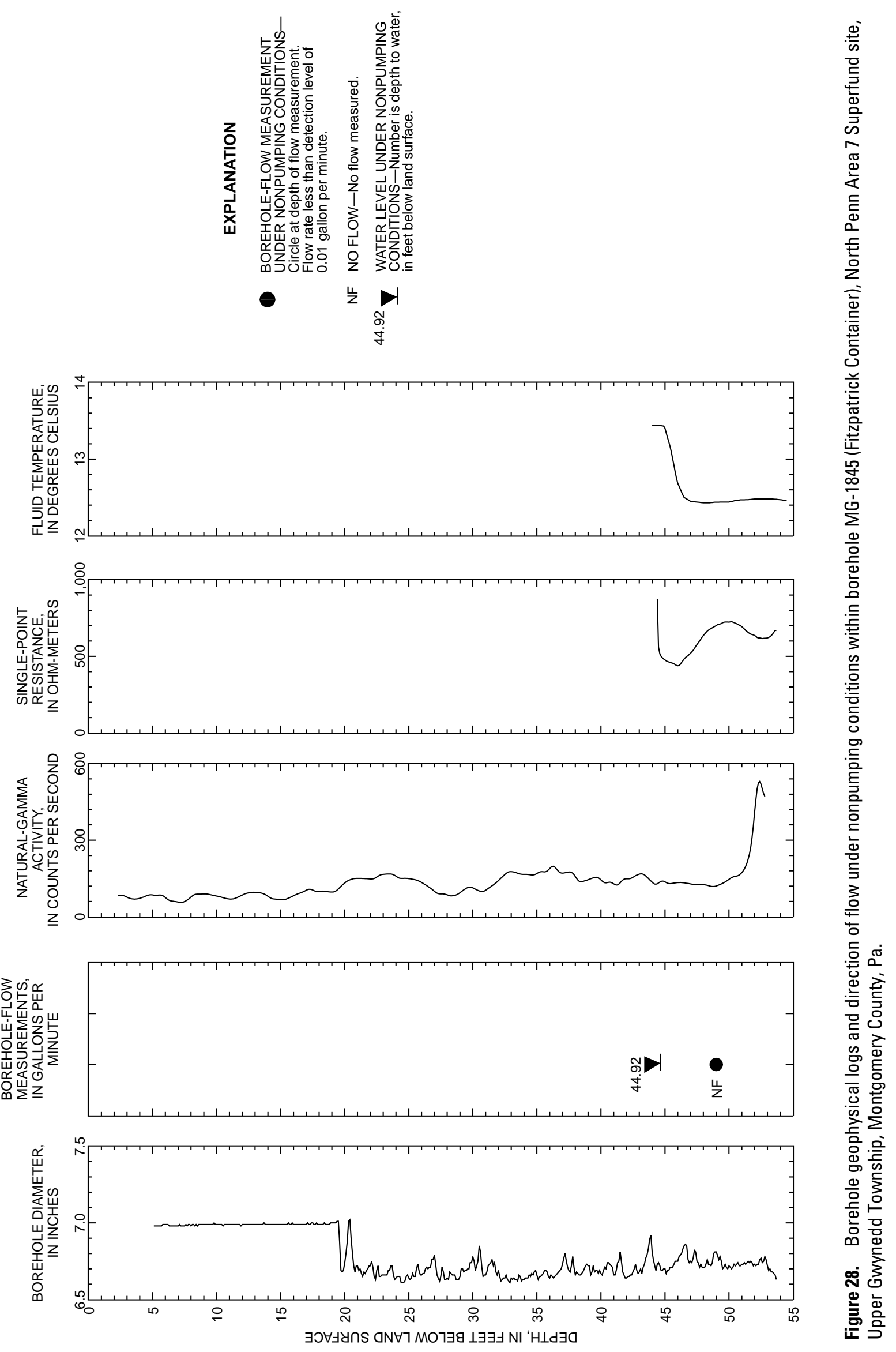




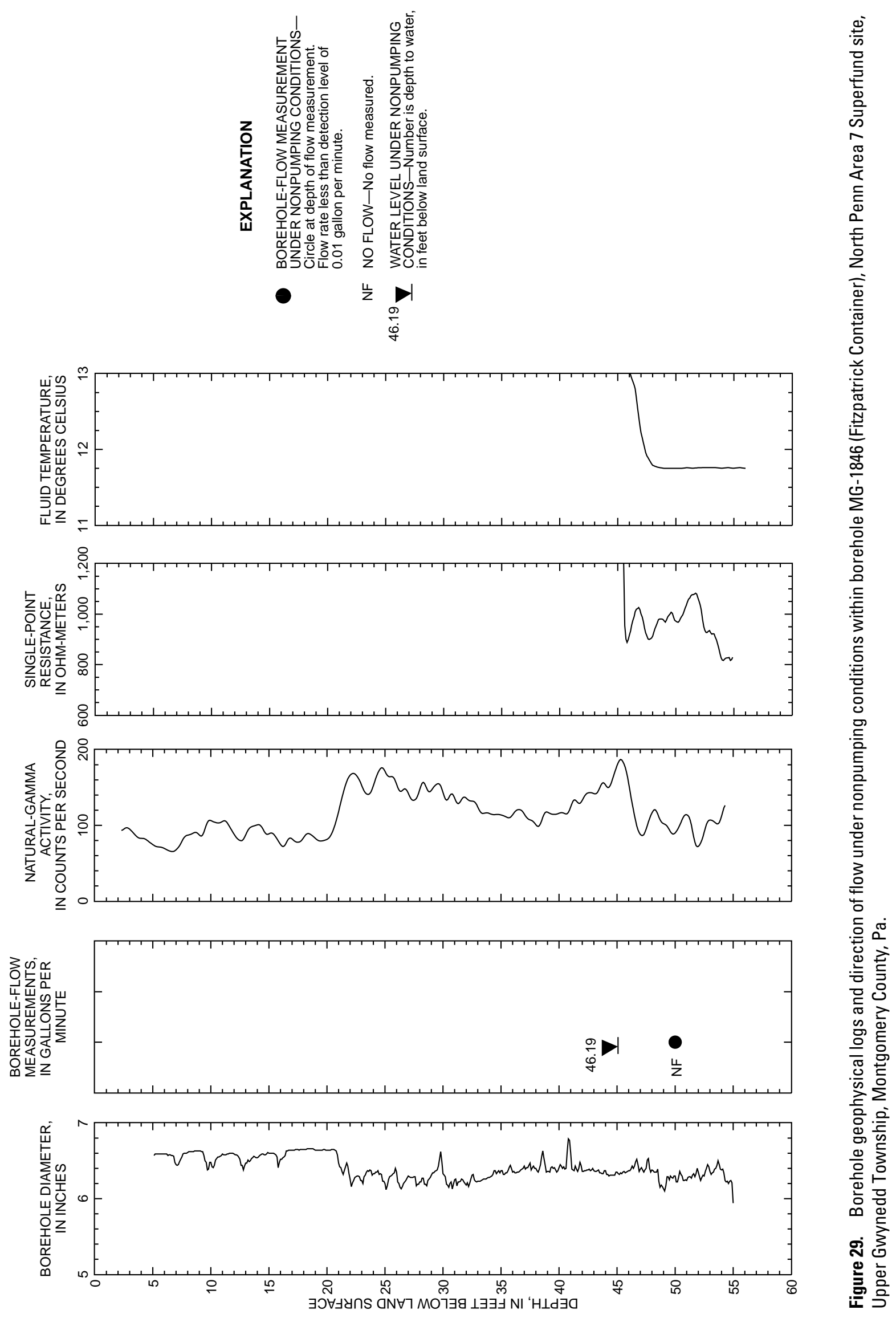



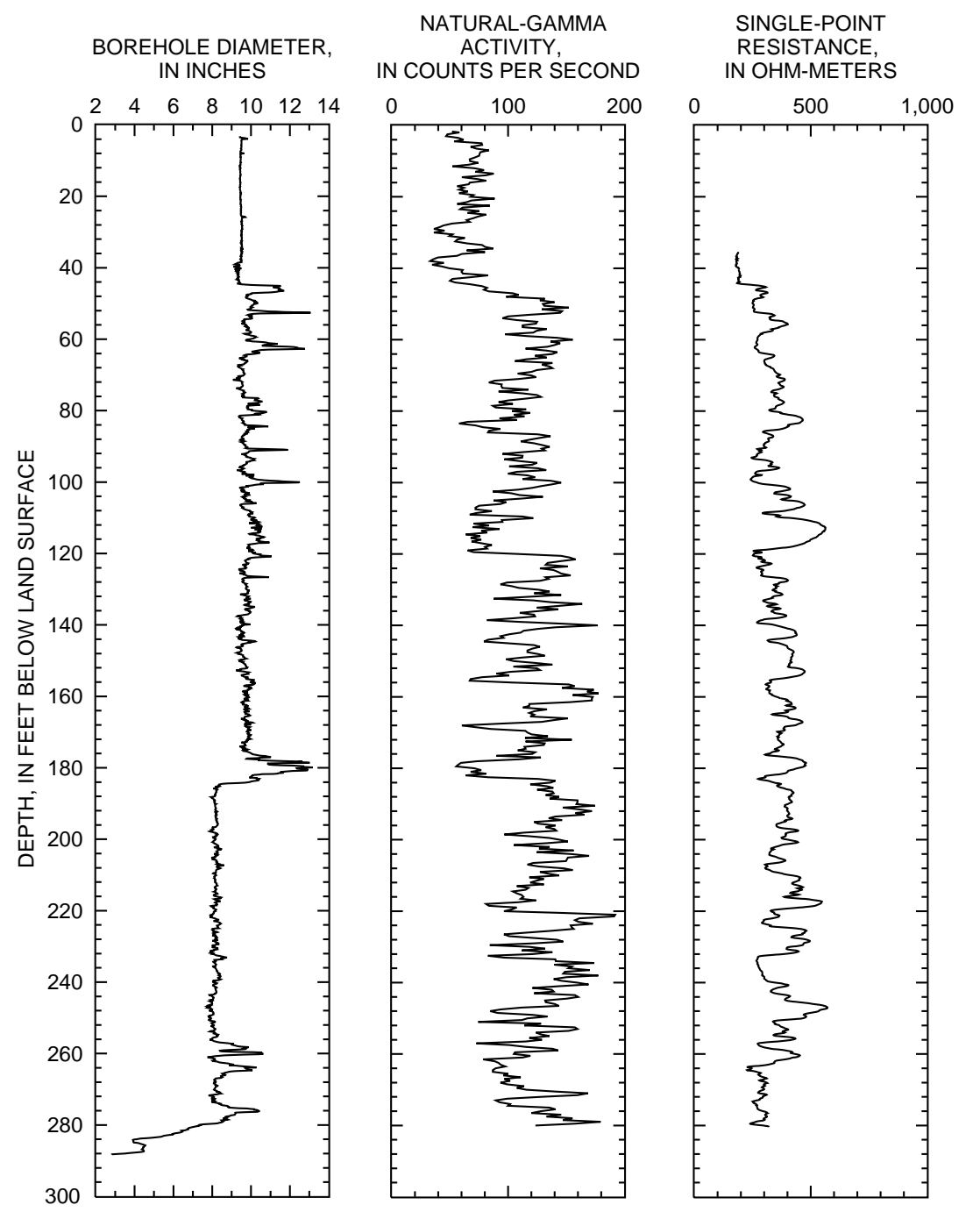

FLUID TEMPERATURE,
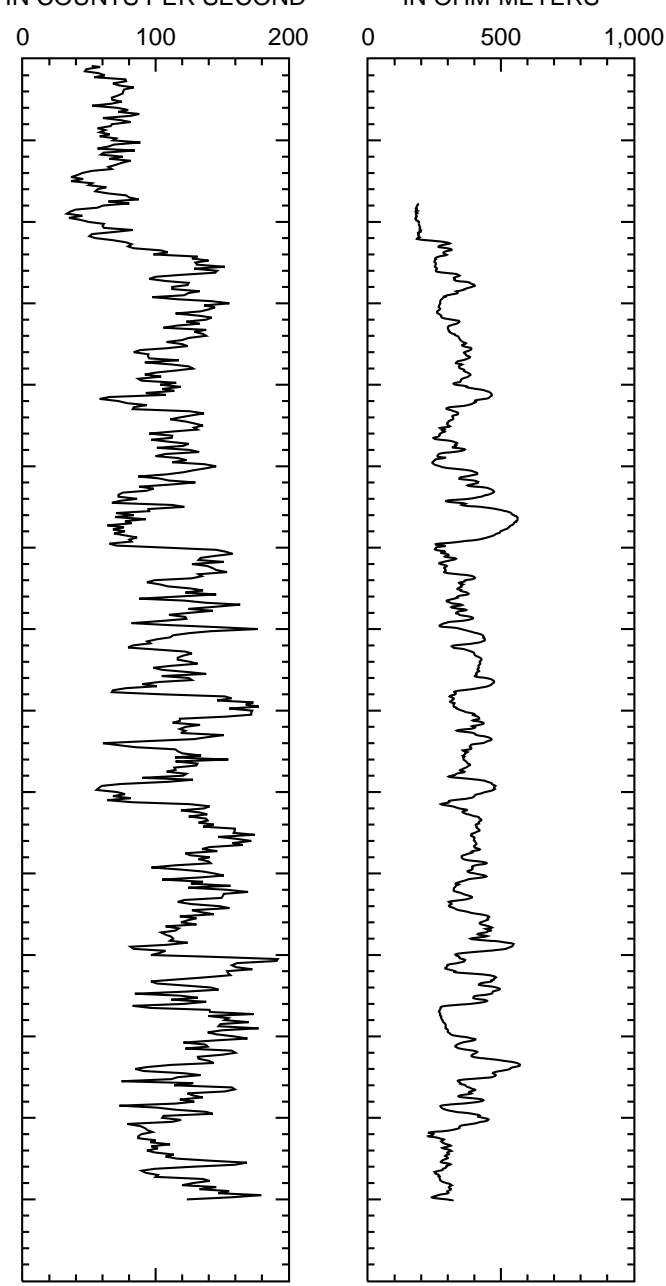

IN DEGREES CELSIUS
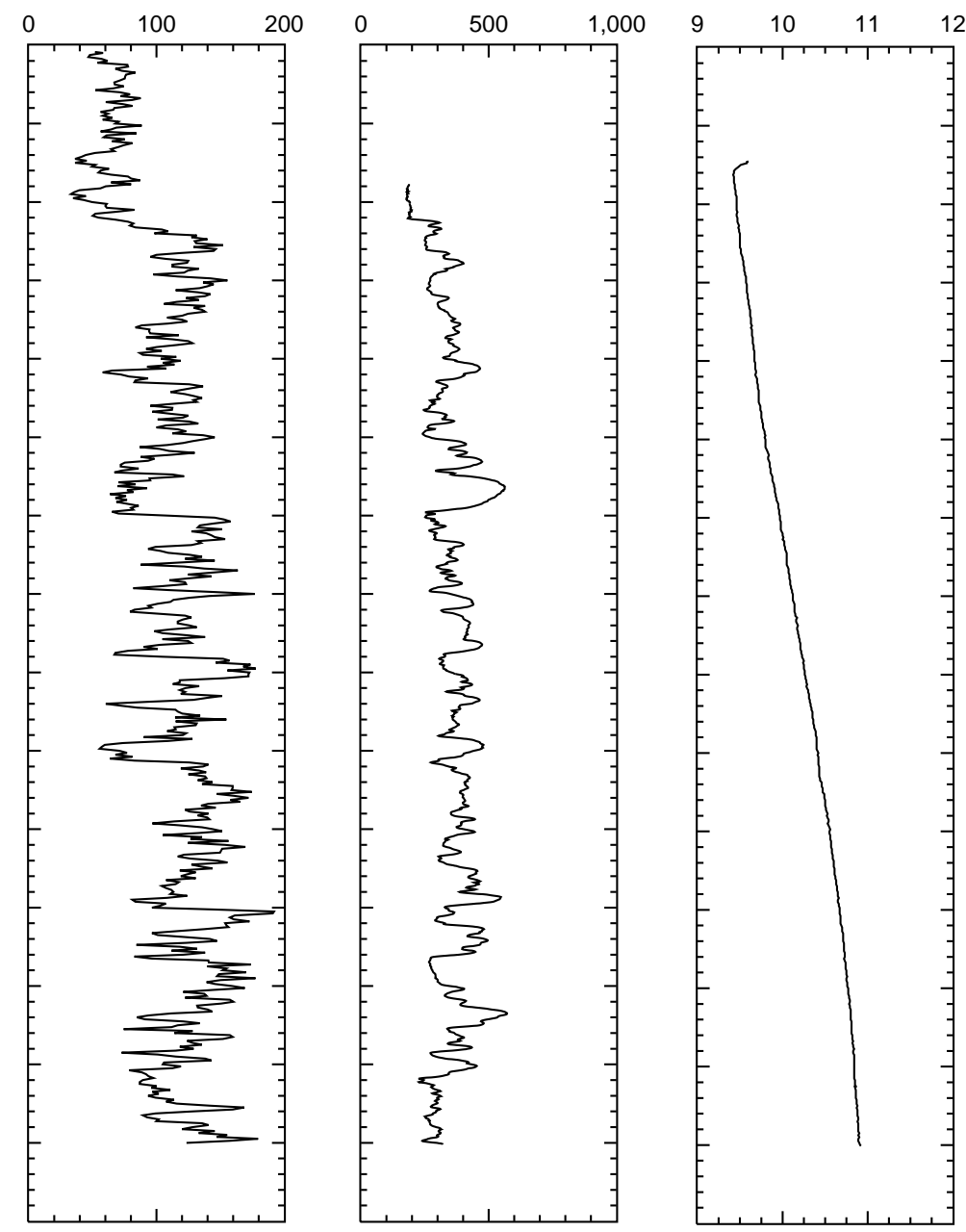

Figure 30. Borehole geophysical logs for borehole MG-1897 (Clearline 3), North Penn Area 7 Superfund site, Upper Gwynedd Township, Montgomery County, Pa.

Under nonpumping conditions, the heatpulse-flowmeter measurements initially were made with a 10-in. diverter in the 10 -in.-diameter section of the borehole above $185 \mathrm{ft}$ bls and with a 8-in. diverter in the 8-in.-diameter section of the borehole below $185 \mathrm{ft}$ bls. No detectable flow was measured at 72, $104,124,130,141,186$, and $246 \mathrm{ft}$ bls (table 22). High concentrations of iron bacteria that were noted during logging may have affected these flow measurements by clogging the central tube of the heatpulse flowmeter when deployed with the 10-in. diverter. Heatpulse-flowmeter measurements under nonpumping conditions were then made using a 8-in. diverter throughout the borehole, an approach that resulted in detecting but underestimating actual flow rates in the 10-in.-diameter section of the borehole above $185 \mathrm{ft}$ bls. Upward flow was measured at 72, 88, 96, 112, 124, 141, 170, and $190 \mathrm{ft}$ bls, and no detectable flow was measured at 50, 58, 220, 246, and $270 \mathrm{ft}$ bls. (fig. 31; table 22). These measurements (table 22) indicate that, under nonpumping conditions, water probably enters the borehole in the intervals between 190 and 220 and 170 and $186 \mathrm{ft}$ bls, moves up, and exits the borehole in the intervals between $58-72 \mathrm{ft}$ bls. These water-bearing zones correspond to observed fractures at 200-210, 176-184, and 61$64 \mathrm{ft}$ bls on the caliper log. The water-bearing fractures at 176184 and 200-210 ft bls are near zones of slightly elevated single-point-resistance measurements that probably indicate sandstone units. For measurements of flow under pumping conditions, a submersible pump was placed at $34 \mathrm{ft}$ bls and the well was pumped at an average rate of about $3 \mathrm{gal} / \mathrm{min}$. After 88 minutes of pumping at about $3 \mathrm{gal} / \mathrm{min}$, the water level declined $3.08 \mathrm{ft}$ to $27.36 \mathrm{ft}$ bls. Heatpulse-flowmeter measurements made under pumping conditions indicate that the intervals between 40 and 50,72 and 88, and 96 and $112 \mathrm{ft}$ bls are the most productive. These producing zones correspond to observed fractures at $45-47,74-81,84$, and $100 \mathrm{ft}$ bls on the caliper log. 


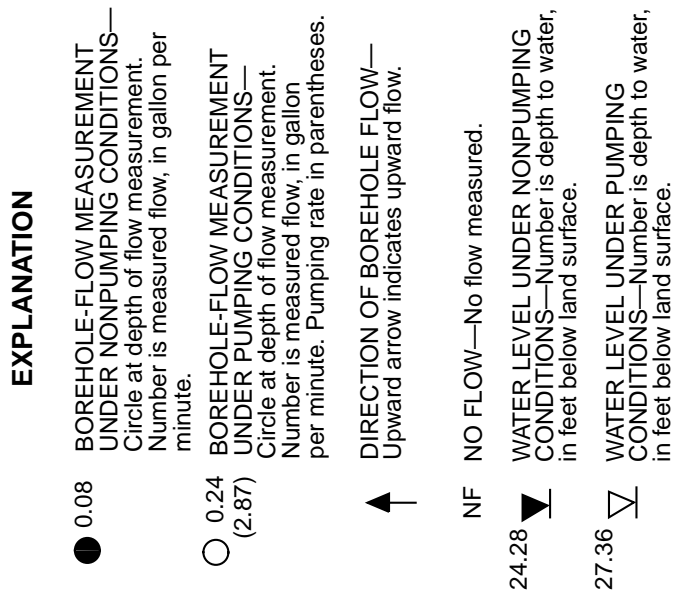

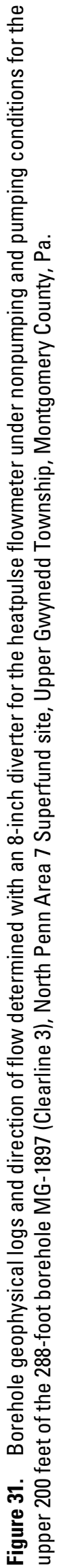

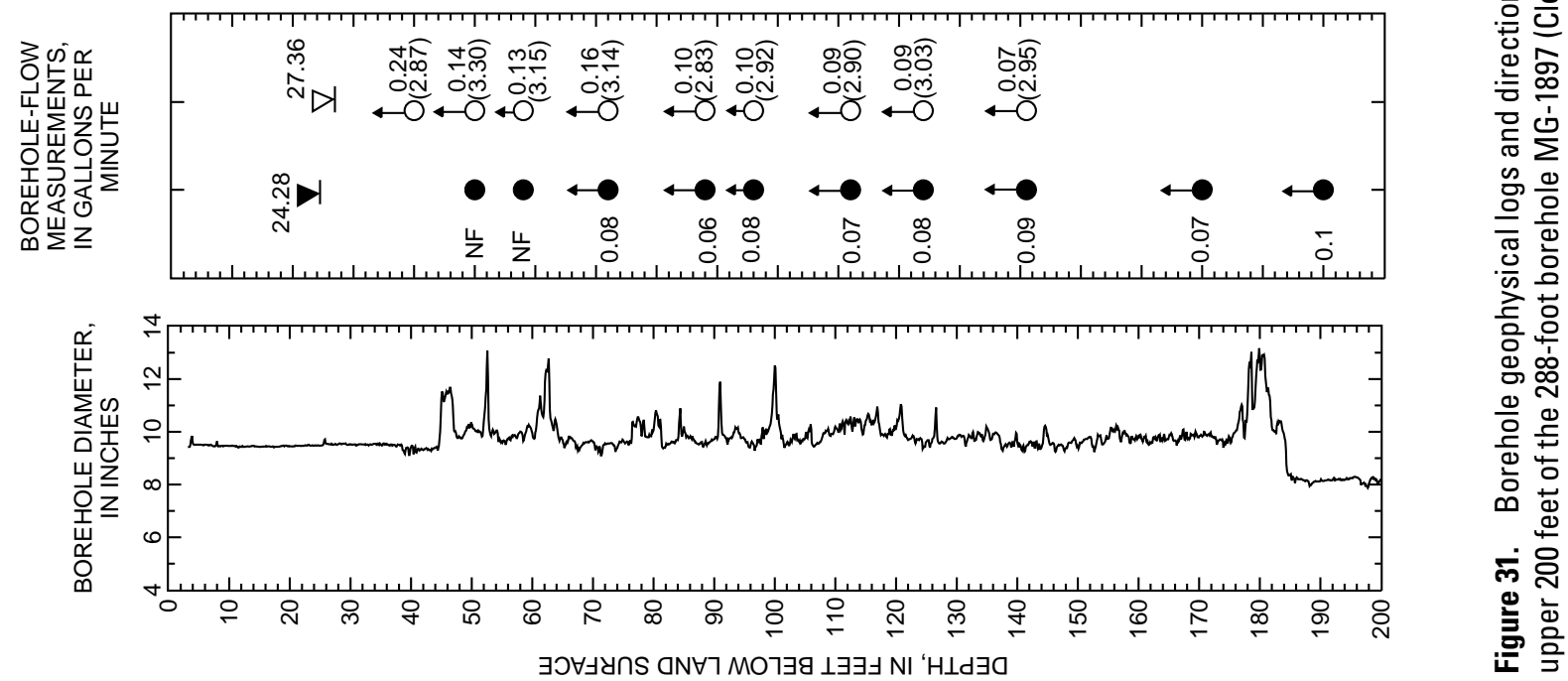


Table 22. Depths, flow rates, flow directions, and pumping rates of heatpulseflowmeter measurements, under nonpumping and pumping conditions, for well MG-1897 (Clearline 3), North Penn Area 7 Superfund site, Upper Gwynedd Township, Montgomery County, Pa.

[ft bls, feet below land surface; gal/min, gallons per minute; NF, no flow measured; --, no data; in., inches]

\begin{tabular}{|c|c|c|c|c|c|c|c|}
\hline \multirow{2}{*}{$\begin{array}{c}\text { Depth } \\
\text { of } \\
\text { measurement } \\
\text { (ft bls) }\end{array}$} & \multicolumn{2}{|c|}{$\begin{array}{l}\text { Nonpumping } \\
\text { conditions }^{1}\end{array}$} & \multicolumn{2}{|c|}{$\begin{array}{c}\text { Nonpumping } \\
\text { conditions }^{2}\end{array}$} & \multicolumn{3}{|c|}{ Pumping conditions ${ }^{2}$} \\
\hline & $\begin{array}{c}\text { Flow } \\
\text { rate } \\
\text { (gal/min) }\end{array}$ & $\begin{array}{c}\text { Flow } \\
\text { direction }\end{array}$ & $\begin{array}{c}\text { Flow } \\
\text { rate } \\
\text { (gal/min) }\end{array}$ & $\begin{array}{c}\text { Flow } \\
\text { direction }\end{array}$ & $\begin{array}{c}\text { Flow } \\
\text { rate } \\
\text { (gal/min) }\end{array}$ & $\begin{array}{c}\text { Flow } \\
\text { direction }\end{array}$ & $\begin{array}{c}\text { Pumping } \\
\text { rate } \\
\text { (gal/min) }\end{array}$ \\
\hline 40 & -- & -- & -- & -- & 0.24 & up & 2.87 \\
\hline 50 & -- & -- & NF & -- & .14 & up & 3.30 \\
\hline 58 & -- & -- & NF & -- & .13 & up & 3.15 \\
\hline 72 & NF & -- & 0.08 & up & .16 & up & 3.14 \\
\hline 88 & -- & -- & .06 & up & .10 & up & 2.83 \\
\hline 96 & -- & -- & .08 & up & .10 & up & 2.92 \\
\hline 104 & $\mathrm{NF}$ & -- & -- & -- & -- & -- & -- \\
\hline 112 & -- & -- & .07 & up & .09 & up & 2.90 \\
\hline 124 & $\mathrm{NF}$ & -- & .08 & up & .09 & up & 3.03 \\
\hline 130 & $\mathrm{NF}$ & -- & -- & -- & -- & -- & -- \\
\hline 141 & NF & -- & .09 & up & .07 & up & 2.95 \\
\hline 170 & -- & -- & .07 & up & -- & -- & -- \\
\hline 186 & $\mathrm{NF}$ & -- & -- & -- & -- & -- & -- \\
\hline 190 & -- & -- & .10 & up & -- & -- & -- \\
\hline 220 & -- & -- & $\mathrm{NF}$ & -- & -- & -- & -- \\
\hline 246 & $\mathrm{NF}$ & -- & $\mathrm{NF}$ & -- & -- & -- & -- \\
\hline 270 & -- & -- & $\mathrm{NF}$ & -- & -- & -- & -- \\
\hline
\end{tabular}

\footnotetext{
${ }^{1}$ A 10 -in.-diameter skirt was used above $185 \mathrm{ft}$ bls (10-in.-diameter hole) and an 8-in.-diameter skirt below $185 \mathrm{ft}$ bls (8-in.-diameter hole).

${ }^{2}$ An 8-in.-diameter skirt was used in both 8-in.- and 10-in.-diameter intervals of the borehole.
}

\section{Correlation of Well Logs}

Stratigraphic correlation between wells in the vicinity of the North Penn Area 7 site was done using elevated naturalgamma and single-point-resistance measurements. Elevated natural-gamma counts may be associated with radiative shales. Elevated single-point-resistance measurements may be associated with sandstones. Correlation of logs in the Lansdale area had been done previously (Conger, 1999) using thin zones of elevated natural-gamma counts to obtain the orientation of bedding, which was reported to strike an average of about $\mathrm{N}$. 43 degrees E. and dip about 10 degrees NW. in a location near the northwestern part of North Penn Area 7 (fig. 4). Correlations were done using altitudes referenced to the National Geodetic Vertical Datum of 1929 (NGVD 29).

The natural-gamma logs used for correlation in a set of wells on the former Ford site were conducted and reported by a private consultant for Ford (Converse Consultants East, 1994). Elevated natural-gamma counts in wells MG-135 (FERCO 3), MG-89 (FERCO 1), and MG-147 (FERCO 4) (fig. 4) at depths of 373.3, 371.2, and $377.4 \mathrm{ft}$ bls, respectively, were correlated by USGS to obtain the bedding orientation of about N. 39 degrees E. strike and 7 degrees NW. dip. Elevated natural-gamma counts in wells MG-89 (FERCO 1), MG-135 (FERCO 3), and MG-151 (FERCO 5) (fig. 4) at depths of $373.3,371.2$, and $361.7 \mathrm{ft}$ bls, respectively, were correlated by USGS to obtain the bedding orientation of about N. 42 degrees E. strike and 8 degrees NW. dip.

Single-point-resistance logs conducted by USGS were correlated between wells MG-174 (Clearline 2), MG-1897 (Clearline 3), and MG-202 (L-22) (fig. 4). Two intervals of elevated resistance about $10-\mathrm{ft}$ thick each that are especially prominent on the log for MG-174, a 6-in.-diameter well, were used for correlation (fig. 32). These intervals are less prominent in the logs for MG-1897 and MG-202, which are larger boreholes with diameters of 10-in. and 12-in. in the correlated intervals, respectively. The orientation of bedding obtained from this correlation indicated beds strike about N. 33 to 37 degrees E. and dip 6 to 7 degrees NW. Possible correlation with a relatively elevated interval of resistance in well MG-1505 also is shown in figure 32. 
岗

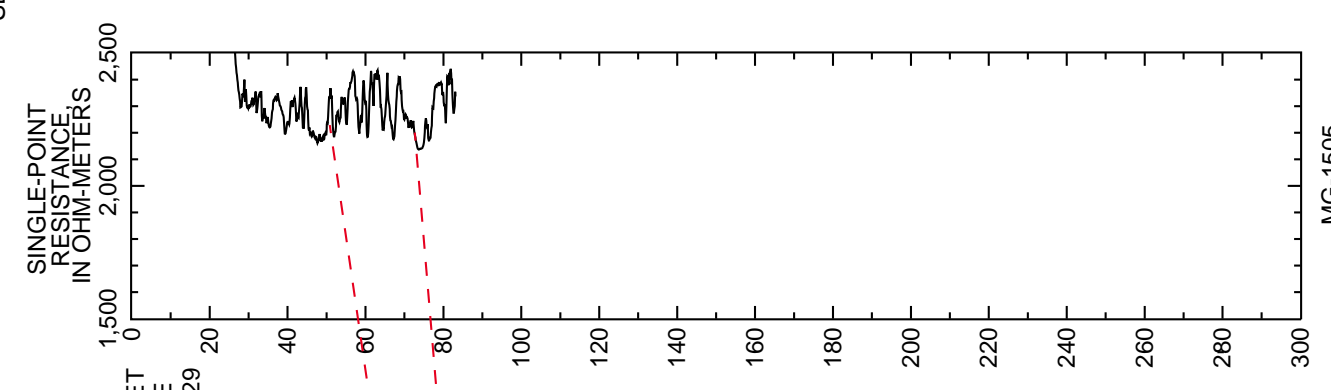

ธ

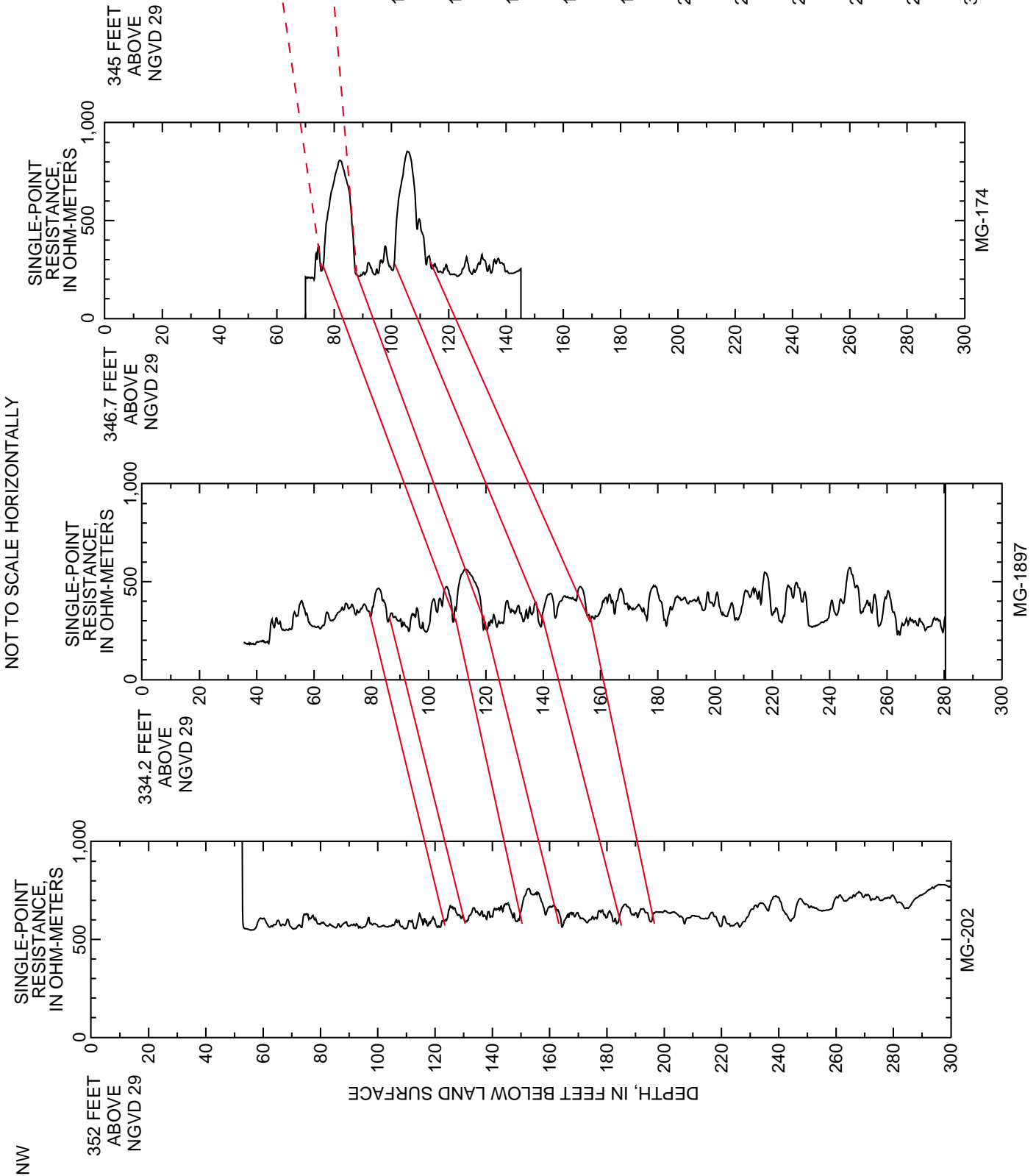

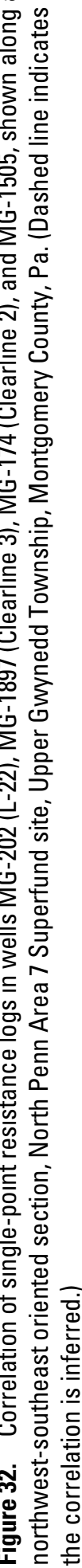


The orientations of bedding estimated from the naturalgamma and single-point-resistance logs are similar to each other and to published attitudes in the area. Previous geologic mapping (Longwill and Wood, 1965) indicated bedding strikes about N. 62 degrees E. and dips 12 degrees NW. in an area about 1,500 to 2,000 ft northwest of the former FERCO site and strikes about N. 31 degrees E. and dips 16 degrees NW. in North Wales Borough about $1.2 \mathrm{mi}$ south-southeast of the former Ford site. The dip of beds reported by Longwill and Wood (1965) in these areas near North Penn Area 7 is slightly (from 4 to 10 degrees) greater than that estimated from the log correlations.

\section{Borehole-Deviation Logs}

Borehole-deviation logs were collected in nine wells (figs. 6, 8, 12, 14, 16, 18, 20, 22, and 25). The borehole-deviation logs for five of the nine wells show a common linear trend. In these five wells (MG-175, 1145, 1146, 1147, and 1148), the boreholes deviate consistently to the southeast (fig. 33), with a mean azimuth of about 126 degrees or about S. 54 degrees E. If the direction of borehole deviation tends to migrate up-dip normal to bedding planes, as has been reported to occur in some cases where bedding dips less than 45 degrees (McLamore, 1971; Brown and others, 1981), then a strike of about N. 36 degrees $\mathrm{E}$. for bedding is indicated by the borehole deviation in these five boreholes. Because the borehole deviation is to the southeast, the dip of the beds would be to the northwest. Assuming the deviation is normal to the bedding plane, the formation dip is estimated from the deviation data to be about from 0.6 to 1.4 degrees NW. This estimated dip was calculated from the total deviation from the shallowest to deepest deviation measurements and does not take into account the tendency for increasing degrees of deviation with increasing depth because of greater flexibility in the drill string with additional rods. Thus, the dip angle calculated from the deviation logs is probably shallower than the actual formation dip.

In three of the four wells that did not show the linear trend to the northwest, the deviation logs indicated the drill bit appeared to migrate to the southeast with depth. Boreholes MG-1144 and MG-1842 initially deviated to the southwest but gradually moved counterclockwise and ended with a southeast deviation trend (figs. 12 and 25). Borehole MG-1149 initially deviated to the northeast and gradually moved clockwise to an almost due east deviation trend at total depth (fig. 22). The remaining borehole showed a 'corkscrew' path, probably as a result of drilling technique rather than formation properties. Borehole MG-174 initially deviated almost due south, then moved abruptly counterclockwise to almost due north, and finished with a deviation trend to the north-northwest (fig. 6).

The bedding strike inferred from the borehole-deviation logs is similar to the strike reported from previous geologic mapping (Longwill and Wood, 1965) and from the log correlation section of this report. However, the magnitude of the dip inferred from the borehole-deviation logs is less than the dip angles of 6 to 12 degrees determined from geologic mapping and $\log$ correlation, as discussed above. Because uncertainty is associated with the interpretation of the borehole-deviation $\operatorname{logs}$, the resulting bedding orientations should be viewed with caution.

\section{Acoustic-Televiewer Logs}

The acoustic-televiewer logs showed no strong pattern of spatial orientation of features associated with bedding planes or water-bearing zones (fig. 34). These findings contrast with results from interpretation of acoustic-televiewer logs for wells in nearby areas in Lansdale, in which bedding-plane features tended to strike northeast and dip shallowly to the northwest and high-angle fractures tended to strike northeast but dip steeply to the northwest (Conger, 1999; Morin and others, 2000). In the wells logged for the North Penn Area 7 study, water-bearing zones are associated with high-angle and lowangle fractures. The lack of a strong spatial pattern in acousticteleviewer results for wells logged in the vicinity of the North Penn Area 7 may be related to geologic characteristics. The orientation of beds that dip at low angles (less than 10 degrees), such as those in the North Penn Area 7 vicinity, are difficult to determine with certainty from the acoustic-televiewer logs. In addition, geologic mapping indicates the lithologic units in the vicinity of North Penn Area 7 are transitional units between the Lockatong Formation and Brunswick Group that may include interfingered facies. Interfingering or internal cross-bedding within sandstone units may result in apparent feature orientations that differ from regional bedding planes on the acousticteleviewer logs. 

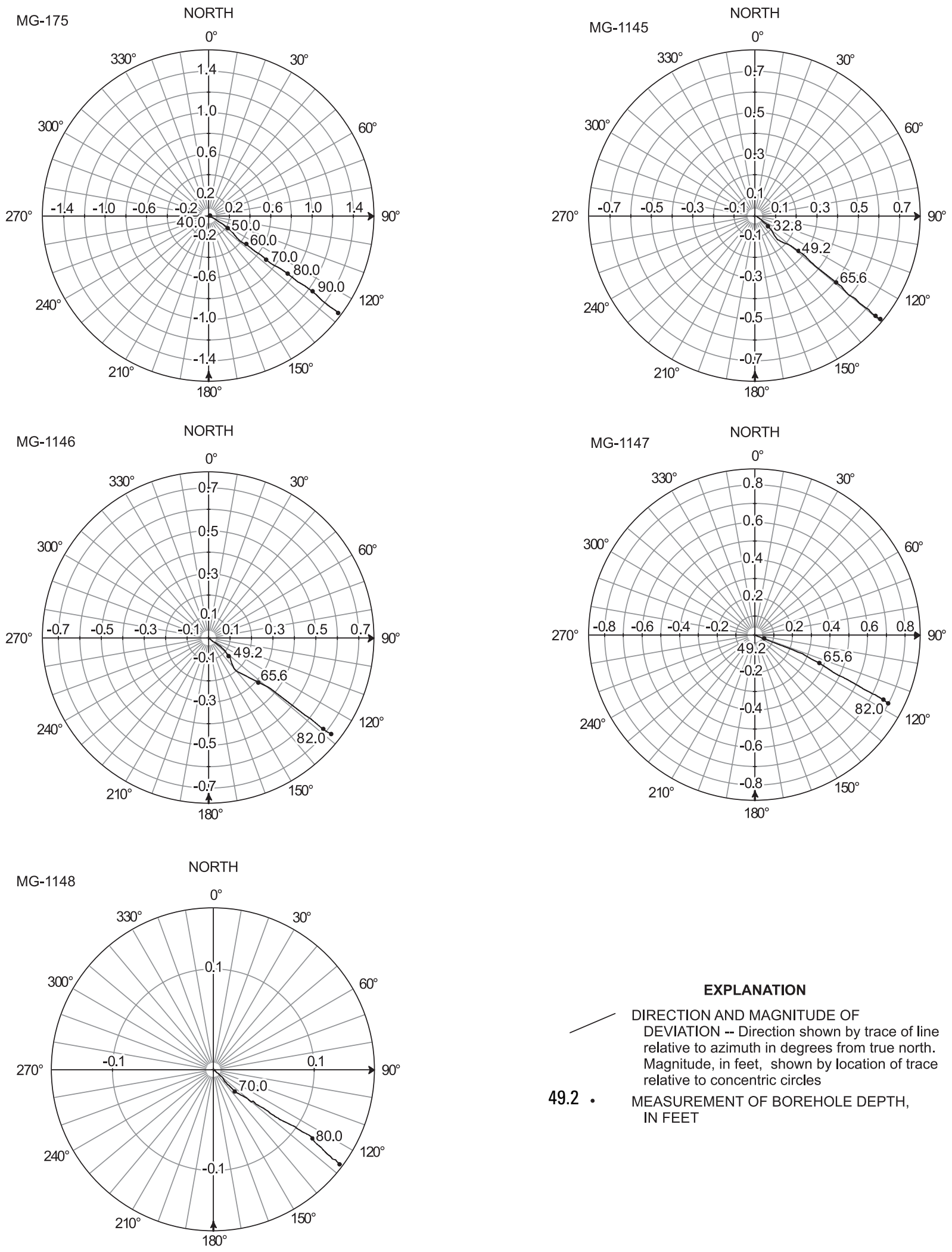

EXPLANATION

DIRECTION AND MAGNITUDE OF DEVIATION -- Direction shown by trace of line relative to azimuth in degrees from true north. Magnitude, in feet, shown by location of trace relative to concentric circles

49.2 - MEASUREMENT OF BOREHOLE DEPTH, IN FEET

Figure 33. Borehole-deviation logs showing linear deviation to the southeast in wells MG-175 (Spra-Fin 1), MG-1145 (T-14), MG-1146 (T-4), MG-1147 (T-11), and MG-1148 (T-12) in the vicinity of North Penn Area 7 Superfund site, Upper Gwynedd Township, Montgomery County, Pa. 


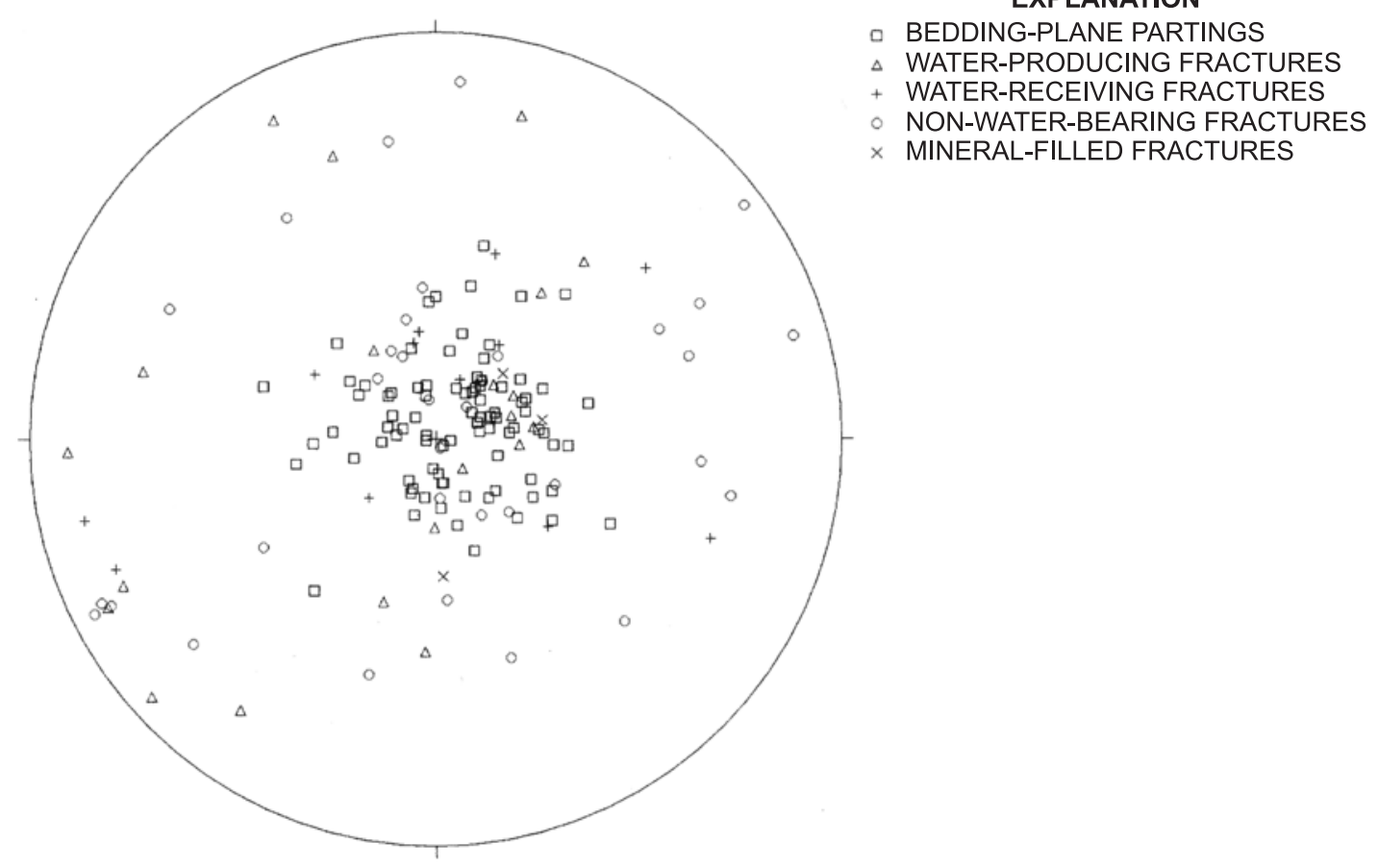

Figure 34. Lower hemisphere stereonet showing orientations as poles to planes of linear features interpreted from acoustic-televiewer logs for nine wells in the vicinity of North Penn Area 7 Superfund site, Upper Gwynedd Township, Montgomery County, Pa.

\section{Aquifer Tests}

Hydraulic conductivity and storage are aquifer properties that may vary spatially because of geologic heterogeneity. Estimation of these properties allows quantitative prediction of the hydraulic response of the aquifer to recharge and pumping. Storage coefficients are important for understanding hydraulic response to transient stresses on aquifers. These properties can be estimated on a local scale by analysis of data from singlewell or multiple-well aquifer tests or on a regional scale by a numerical simulation of ground-water flow using a computerbased model. The local scale ranges from tens of feet to hundreds of feet. The regional scale is characterized by lengths of hundreds to thousands of feet. Transmissivity, the hydraulic conductivity multiplied by the saturated thickness of the aquifer, represents a vertical average of hydraulic conductivities that may vary with depth. Many of the analytical techniques used to estimate the hydraulic properties of aquifers were developed for porous media, such as unconsolidated sediments. These techniques may provide reasonable estimates of hydraulic properties in fractured rocks when the hydraulic response of the fractured-rock aquifers approximates porous media at the scale of interest. In this report, steady-state conditions are assumed with the regional-scale flow model; hence, the storage coefficient cannot be estimated from it.
In a review of aquifer-test data collected prior to this study (pre-1995), Goode and Senior (1998) summarized the range of estimated transmissivity and storage coefficients. Estimates of transmissivity ranged from 0 to about $5,400 \mathrm{ft}^{2} / \mathrm{d}$; estimates from most tests ranged from 108 to $1,080 \mathrm{ft}^{2} / \mathrm{d}$. Estimates of storage coefficients ranged from 0.00001 to 0.26 , and most estimates ranged from 0.0001 to 0.007 .

As part of this study, two types of aquifer tests were conducted by the USGS and others in the vicinity of North Penn Area 7 from September 2001 through May 2002. Single-well, aquifer-interval-isolation tests were done by USGS in eight boreholes. One multiple-well test (single pumping well and multiple observation wells) was done by USGS with cooperation of NPWA.

\section{Single-Well, Interval-Isolation Tests}

Water enters open-hole wells through discrete openings or zones in fractured-rock aquifers. Because most groundwater flow and contaminant movement at the site is through distinct water-bearing zones made up of one or more fracture(s), the hydraulic and chemical characteristics of each water-bearing zone can differ. By isolating these discrete zones with inflatable packers, hydraulic properties of individual zones and the extent of vertical hydraulic connection 
between zones can be determined. This determination provides data on the vertical distribution of hydraulic properties.

The USGS performed single-well, aquifer-interval-isolation tests in nine wells (table 23). Most wells were known to yield water containing VOCs and some were near known sources of soil contamination. The objectives of the singlewell, interval-isolation tests were to (1) provide information on hydraulic heads (water levels) and specific capacities of discrete vertical intervals and the hydraulic connection between intervals, and (2) provide water samples from discrete waterbearing intervals to allow the USEPA to characterize the vertical extent of contamination in each well.

Inflatable packers were set to isolate selected water-bearing (producing or receiving) zones. The number and depths of intervals to be tested in each open-hole well were based on an analysis of the borehole geophysical logs. The likelihood of obtaining a seal by the packers was considered in the selection of intervals. The seal of the packer against the borehole wall is critical for isolating the interval and can be affected by roughness or changes in borehole diameter related to presence of fractures, lithology, or drilling methods.

A set of straddle packers was used to isolate three intervals and a single packer was used to isolate two intervals in the open-hole wells. Two types of packers were used depending on borehole diameter. In boreholes smaller than 8 in., packers with a 2-ft rubber bladder that, when inflated, sealed off approximately $1 \mathrm{ft}$ of the borehole between adjacent intervals, were used. In boreholes larger than 8 in., packers with a $5.9-\mathrm{ft}$ rubber bladder that, when inflated, sealed off approximately 4 $\mathrm{ft}$ of the borehole between adjacent intervals, were used. The actual length of borehole wall sealed by any packer largely depends on actual borehole diameter, borehole condition, and inflation pressure. Water levels in each isolated zone were measured before and after packer inflation using electric tapes. The reference measuring point for water levels and all logged depths was land surface. Water levels were measured continuously in all zones by pressure transducers before, during, and after pumping. Pumping duration and rate depended on aquifer properties. Pumping duration was as short as 4 minutes in a very tight zone (low hydraulic conductivity) but was typically from 1 to 2 hours in each zone tested. Attempts were made to maintain constant pumping rates for each test. Pumping rates commonly were from 1 to $2 \mathrm{gal} / \mathrm{min}$ and ranged from about 0.25 to $12.4 \mathrm{gal} / \mathrm{min}$ for all intervals tested.

Evaluation of the packer seal and hydraulic connections between isolated intervals followed packer inflation. Little or no head separation (difference in water levels) after packer inflation indicates a hydraulic connection between isolated intervals that may be caused by an incomplete packer seal or hydraulic connection through fractures outside the borehole. Conversely, head separation after packer inflation indicates little or no hydraulic connection between isolated intervals. Pumping was started when water levels stabilized after packer inflation. The extent of hydraulic connection between isolated intervals is indicated by the extent of head separation and response to pumping in the various isolated intervals. A noted response to pumping stress in an adjacent interval generally indicates a hydraulic connection between isolated intervals, and no response to pumping stress in adjacent intervals indicates low, or no, hydraulic connection between isolated intervals.

Table 23. List of wells tested using aquifer-interval-isolation methods in the vicinity of the North Penn Area 7 Superfund site, Upper Gwynedd Township, Montgomery County, Pa., September 2001 through May 2002.

[Locations of wells are shown on figure 4]

\begin{tabular}{llccc}
\hline $\begin{array}{c}\text { U.S. } \\
\text { Geological } \\
\text { Survey } \\
\text { local well } \\
\text { number }\end{array}$ & $\begin{array}{c}\text { Owner } \\
\text { well } \\
\text { name }\end{array}$ & $\begin{array}{c}\text { Depth } \\
\text { of } \\
\text { well, } \\
\text { in feet }\end{array}$ & $\begin{array}{c}\text { Number } \\
\text { of } \\
\text { zones } \\
\text { tested }\end{array}$ & $\begin{array}{c}\text { Date(s) } \\
\text { of } \\
\text { tests } \\
\text { (month/ } \\
\text { day(s)/year) }\end{array}$ \\
\hline MG-174 & Clearline 2 & 160 & 6 & $9 / 17-21 / 01$ \\
MG-175 & Spra-Fin 1 & 103 & 3 & $4 / 22-23 / 02$ \\
MG-202 & NPWA L-22 & 623 & 4 & $12 / 17-20 / 01$ \\
MG-1144 & T-13 & 84 & 4 & $11 / 28-30 / 01$ \\
MG-1145 & T-14 & 83 & 3 & $12 / 5-6 / 01$ \\
MG-1146 & T-4 & 84.5 & 2 & $11 / 27-28 / 01$ \\
MG-1147 & T-11 & 83.5 & 2 & $11 / 15-16 / 01$ \\
MG-1842 & T-15 & 86 & 2 & $11 / 14 / 01$ \\
MG-1897 & Clearline 3 & 288 & 4 & $11 / 6-9 / 01$ \\
\hline
\end{tabular}

Specific capacities and estimated transmissivity for each isolated zone were calculated. These results are compared to additional data, where available, on specific capacities of the open-hole wells determined from pumping rates and drawdowns during pumping for heatpulse-flowmeter logs. The estimated transmissivity $(T)$ was calculated using the Thiem equation (Bear, 1979), assuming steady-state conditions, as:

$$
T=\frac{Q}{2 \pi \Delta h} \ln \frac{r_{0}}{r_{w}}
$$

where

$Q$ is pumping rate,

$\Delta h$ is change in head,

$r_{0}$ is radius of influence of pumping,

and

$$
r_{w} \quad \text { is radius of well. }
$$

For analysis of data from single-well, interval-isolation tests in the nine wells, $r_{0}$ was assumed to equal $328 \mathrm{ft}(100 \mathrm{~m})$. This method of estimating transmissivity is similar to that used by Shapiro and Hsieh (1998) for short-term (hours), low-injection-rate, single-well, interval-isolation tests in low-permeability fractured rocks. For the tests by Shapiro and Hsieh (1998), $r_{0}$ was assumed to equal $9.8 \mathrm{ft}(3 \mathrm{~m})$. The rate and duration of pumping of tests for the present study were greater than in the tests by Shapiro and Hsieh (1998), and it is reasonable to assume that $r_{0}$ would be greater than $9.8 \mathrm{ft}(3 \mathrm{~m})$. 
The chemical and physical properties of borehole discharge were measured at various times by the USGS during pumping using temperature-compensated $\mathrm{pH}$ and specificconductance meters. After physical and chemical properties stabilized or after three test-interval volumes of borehole water were pumped, water samples were collected for measurement of $\mathrm{pH}$, specific conductance, temperature, alkalinity, and dissolved-oxygen concentration. Samples for VOC analysis then were collected by the USGS and forwarded to the USEPA contractor, CDM Federal, Inc., for analysis. The $\mathrm{pH}$ and specific conductance were measured by methods outlined in Wood (1976). Dissolved oxygen was measured using the aide modification of the Winkler titration method (American Public Health Association and others, 1976).

\section{Well MG-174 (Clearline 2)}

Geophysical logging of well MG-174 indicated probable water-bearing zones in the intervals between 73 and 83,83 and 96, 96 and 106, 106 and 122, and 122 and $140 \mathrm{ft}$ bls. The water-bearing zones correspond to fractures detected in these intervals on the caliper log (fig. 5). When the well was pumped for heatpulse-flowmeter measurements, the interval between 73 and $83 \mathrm{ft}$ bls apparently was the most productive. Five intervals (zones 1-5, table 24) initially were selected for isolation on the basis of geophysical logging results and a sixth interval (zone 6) was tested on the basis of results from the first five interval tests. The spacing between the mid-points of the straddle packers was $14 \mathrm{ft}$ for zones $1-5$ and $24 \mathrm{ft}$ for zone 6 .

Table 24. Isolated intervals tested in well MG-174 (Clearline 2), North Penn Area 7 Superfund site, Upper Gwynedd Township, Montgomery County, Pa., September 2001.

[ft bls, feet below land surface]

\begin{tabular}{ccc}
\hline Zone & $\begin{array}{c}\text { Depth of } \\
\text { isolated } \\
\text { interval } \\
\text { (ft bls) }\end{array}$ & $\begin{array}{c}\text { Date } \\
\text { of } \\
\text { test } \\
\text { (month/day/year) }\end{array}$ \\
\hline 1 & Below 120 & $9 / 17 / 01$ \\
2 & $106-120$ & $9 / 18 / 01$ \\
3 & $92-106$ & $9 / 18 / 01$ \\
4 & $81-95$ & $9 / 19 / 01$ \\
$14 \mathrm{~A}$ & $82-96$ & $9 / 20 / 01$ \\
5 & $68-82$ & $9 / 19 / 01$ \\
6 & $82-106$ & $9 / 21 / 01$ \\
\hline
\end{tabular}

${ }^{1}$ Second test of zone 4 done 1 -foot deeper than first test.

The test of zone 1 indicated the interval above $120 \mathrm{ft}$ bls was connected hydraulically to the pumped interval below
$120 \mathrm{ft}$ bls because drawdown and recovery were near identical in the two intervals (fig. 35). The test of zone 2 showed the pumped interval between 106 and $120 \mathrm{ft}$ bls was hydraulically connected to the interval below $120 \mathrm{ft}$ bls and isolated from the interval above $106 \mathrm{ft}$ bls (fig. 35). The test of zone 3 showed the pumped interval between 92 and $106 \mathrm{ft}$ bls had low hydraulic connection to the interval below $106 \mathrm{ft}$ bls and was hydraulically connected to the interval above $92 \mathrm{ft}$ bls (fig. 36). The test of zone 4 showed that the pumped interval between 81 and $95 \mathrm{ft}$ bls was connected hydraulically to intervals above $81 \mathrm{ft}$ bls and below $95 \mathrm{ft}$ bls; however, with increased packer pressure to create a tighter packer seal, the hydraulic connection between the pumped interval and the interval above $81 \mathrm{ft}$ bls decreased (fig. 36). A second test (zone 4A) of zone 4 was done where the interval 82-96 ft bls was isolated only (not pumped), which indicated the interval above $82 \mathrm{ft}$ bls was isolated hydraulically from the lower intervals (fig. 37). The test of zone 5 showed that the pumped interval between 68 and $82 \mathrm{ft}$ bls had low hydraulic connection to the interval below $82 \mathrm{ft}$ bls and was connected hydraulically to the interval above $68 \mathrm{ft}$ bls (fig. 37). A sixth zone (zone 6) was selected for testing where packers were set at depths ( 82 and $106 \mathrm{ft}$ bls) that showed little to no vertical connection during earlier tests. The test of zone 6 confirmed that the interval between 82 and $106 \mathrm{ft}$ bls was isolated from adjacent intervals above and below (fig. 38).

Tests of the first five zones described above showed some intervals were connected either in the borehole as a result of inadequate packer seal or outside of the borehole as a result of aquifer properties. Where head separation occurred after packer inflation, the water level below the isolated interval was higher than above the isolated interval, indicating an upward vertical gradient. Upward vertical flow was measured in the borehole under nonpumping conditions at the time of geophysical logging.

Results of the isolation tests indicate three major hydraulically isolated producing intervals in the well: above $82 \mathrm{ft}$ bls (zone 4A, zone 5 tests); $82-106 \mathrm{ft}$ bls (zone 6 test); and below $106 \mathrm{ft}$ bls (zone 2 test). The interval below $106 \mathrm{ft}$ bls has a higher specific capacity than the other two intervals (fig. 39; table 25), differing from the results obtained from geophysical logging. The exact specific capacity for the interval below 106 $\mathrm{ft}$ was not determined but can be estimated from results of the zone 2 test (106-120 ft bls). 

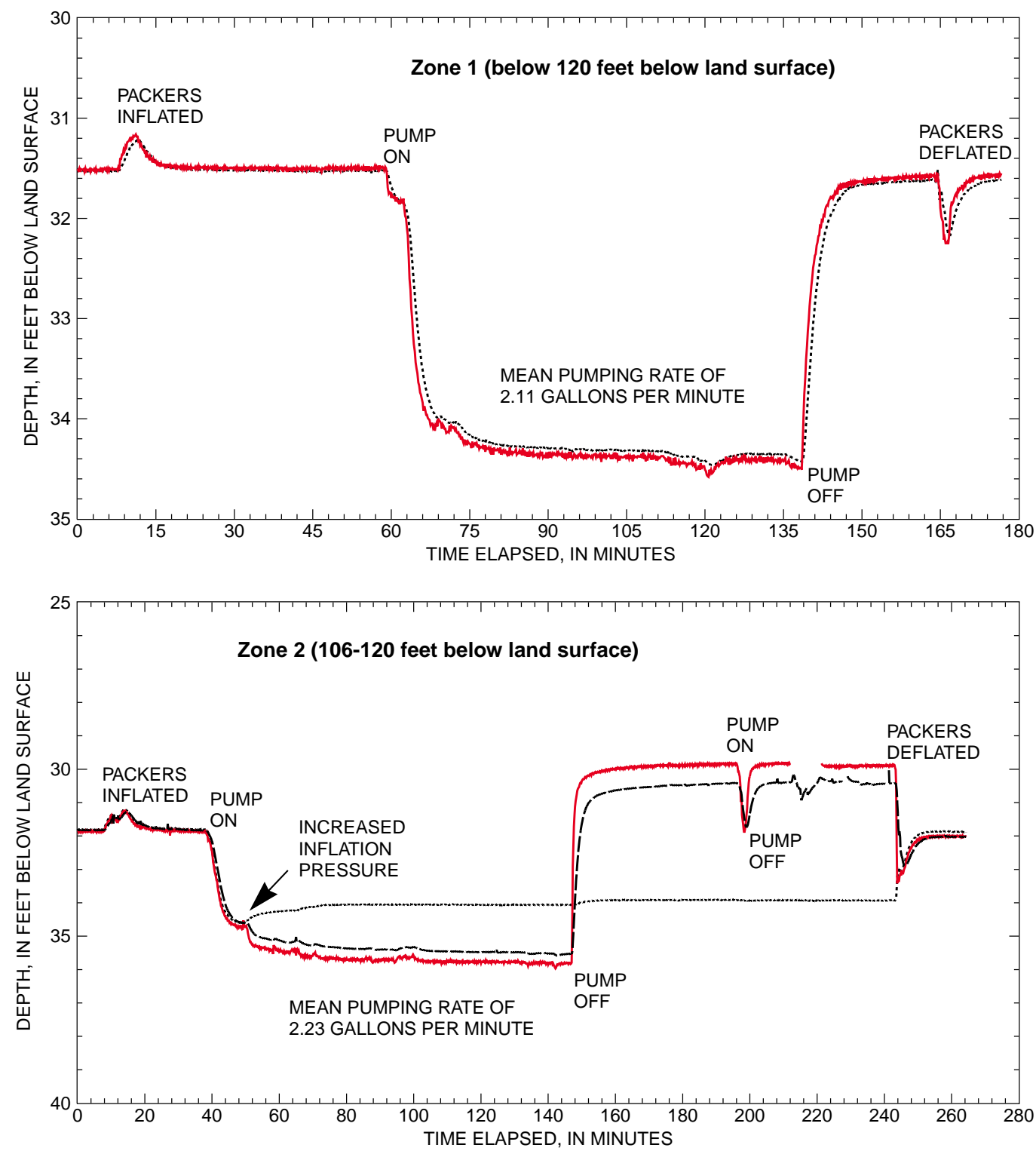

EXPLANATION

WATER LEVEL ABOVE THE ISOLATED INTERVAL WATER LEVEL IN THE ISOLATED INTERVAL WATER LEVEL BELOW THE ISOLATED INTERVAL

Figure 35. Depth to water above isolated interval, in isolated interval, and below isolated interval before, during, and after pumping for tests of isolated intervals zone 1 (below 120 feet below land surface) and zone 2 (between 106 and 120 feet below land surface) in well MG-174 (Clearline 2), North Penn Area 7 Superfund site, Upper Gwynedd Township, Montgomery County, Pa., September 17-18, 2001. 

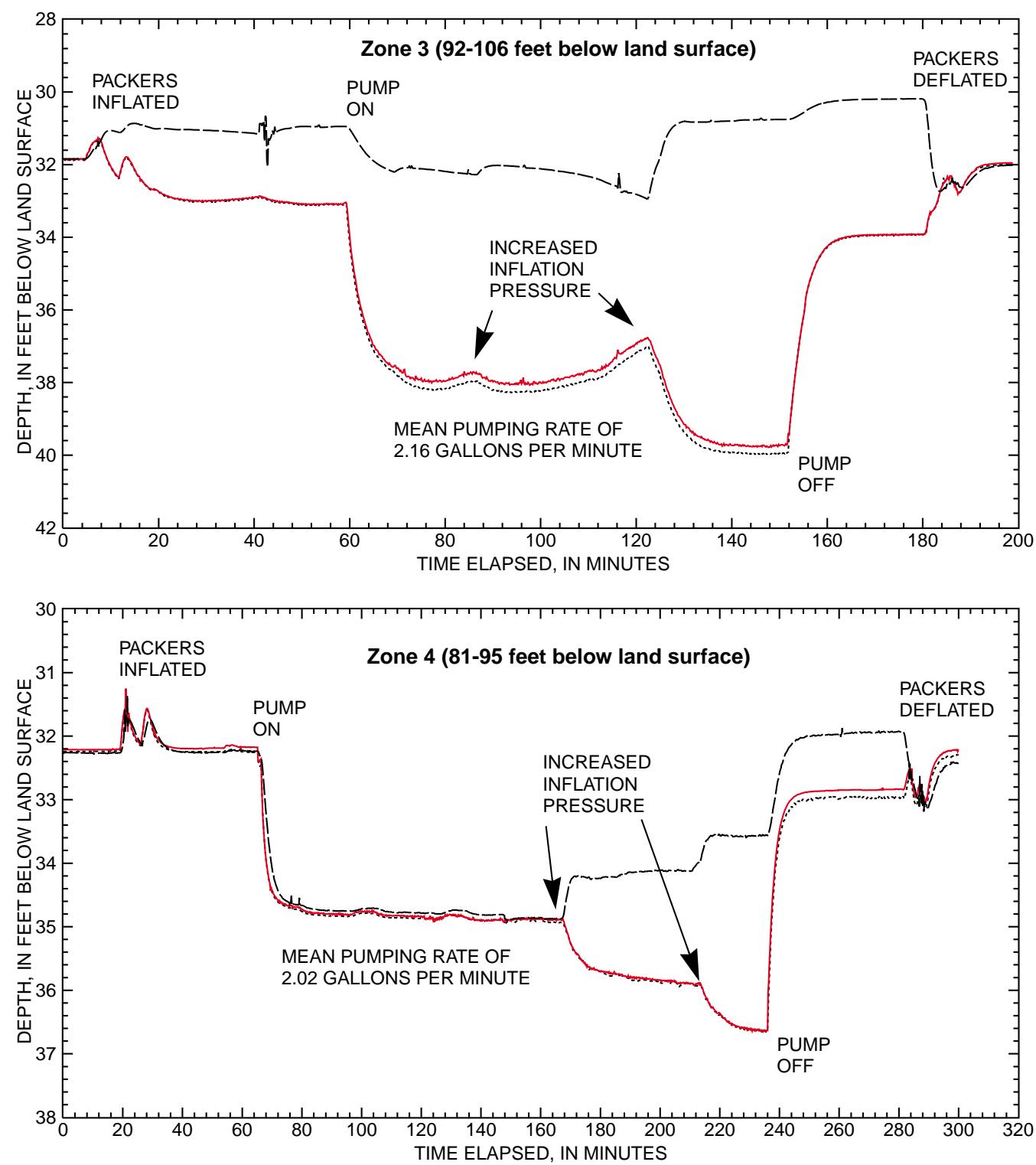

\section{EXPLANATION}

WATER LEVEL ABOVE THE ISOLATED INTERVAL

WATER LEVEL IN THE ISOLATED INTERVAL

WATER LEVEL BELOW THE ISOLATED INTERVAL

Figure 36. Depth to water above isolated interval, in isolated interval, and below isolated interval before, during, and after pumping for tests of isolated intervals zone 3 (between 92 and 106 feet below land surface) and zone 4 (between 81 and 95 feet below land surface) in well MG-174 (Clearline 2), North Penn Area 7 Superfund site, Upper Gwynedd Township, Montgomery County, Pa., September 18-20, 2001. 

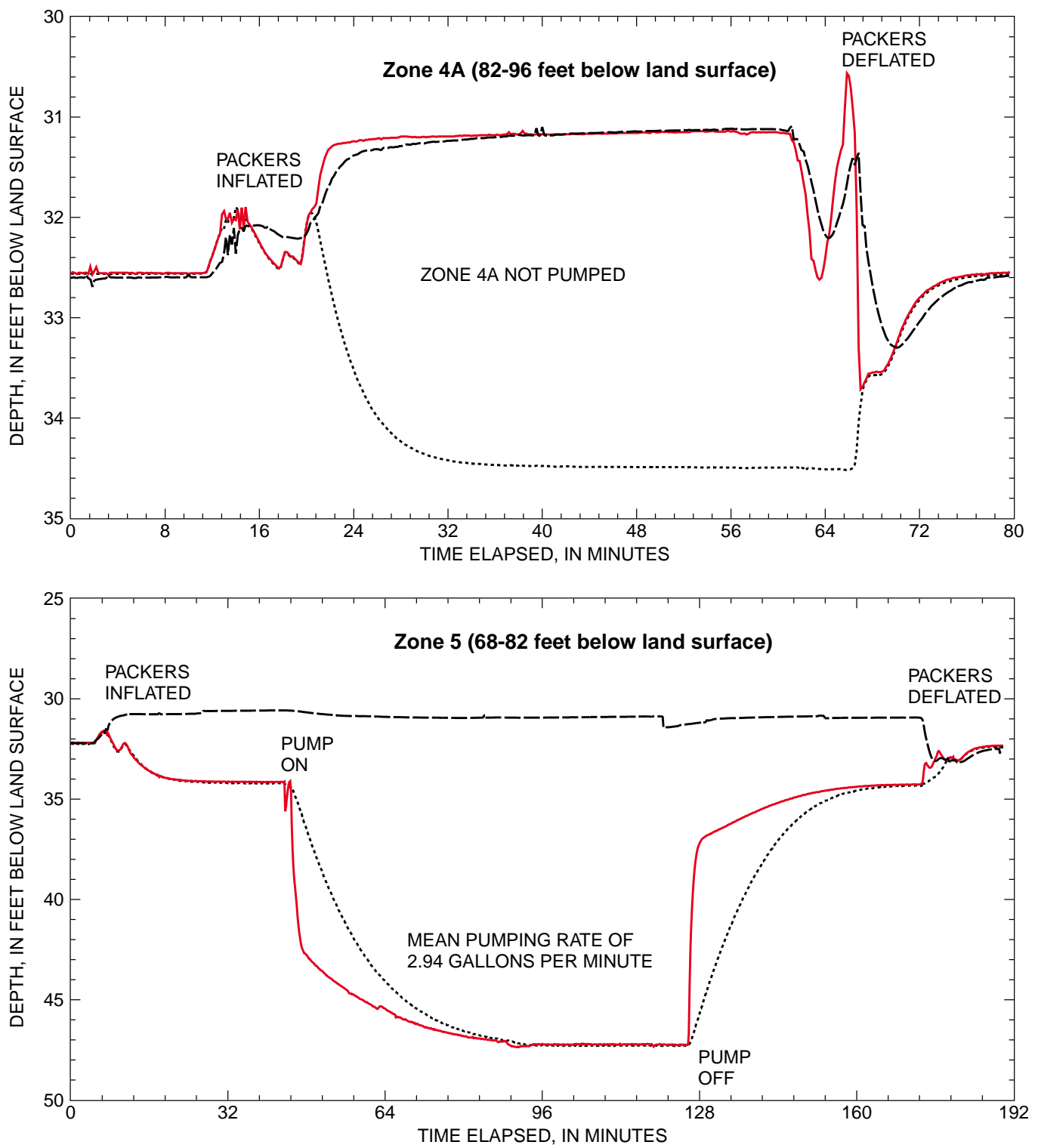

EXPLANATION

WATER LEVEL ABOVE THE ISOLATED INTERVAL

WATER LEVEL IN THE ISOLATED INTERVAL

WATER LEVEL BELOW THE ISOLATED INTERVAL

Figure 37. Depth to water above isolated interval, in isolated interval, and below isolated interval before, during, and after pumping for tests of isolated intervals zone 4A (between 82 and 96 feet below land surface) and zone 5 (between 68 and 82 feet below land surface) in well MG-174 (Clearline 2), North Penn Area 7 Superfund site, Upper Gwynedd Township, Montgomery County, Pa., September 19, 2001. 


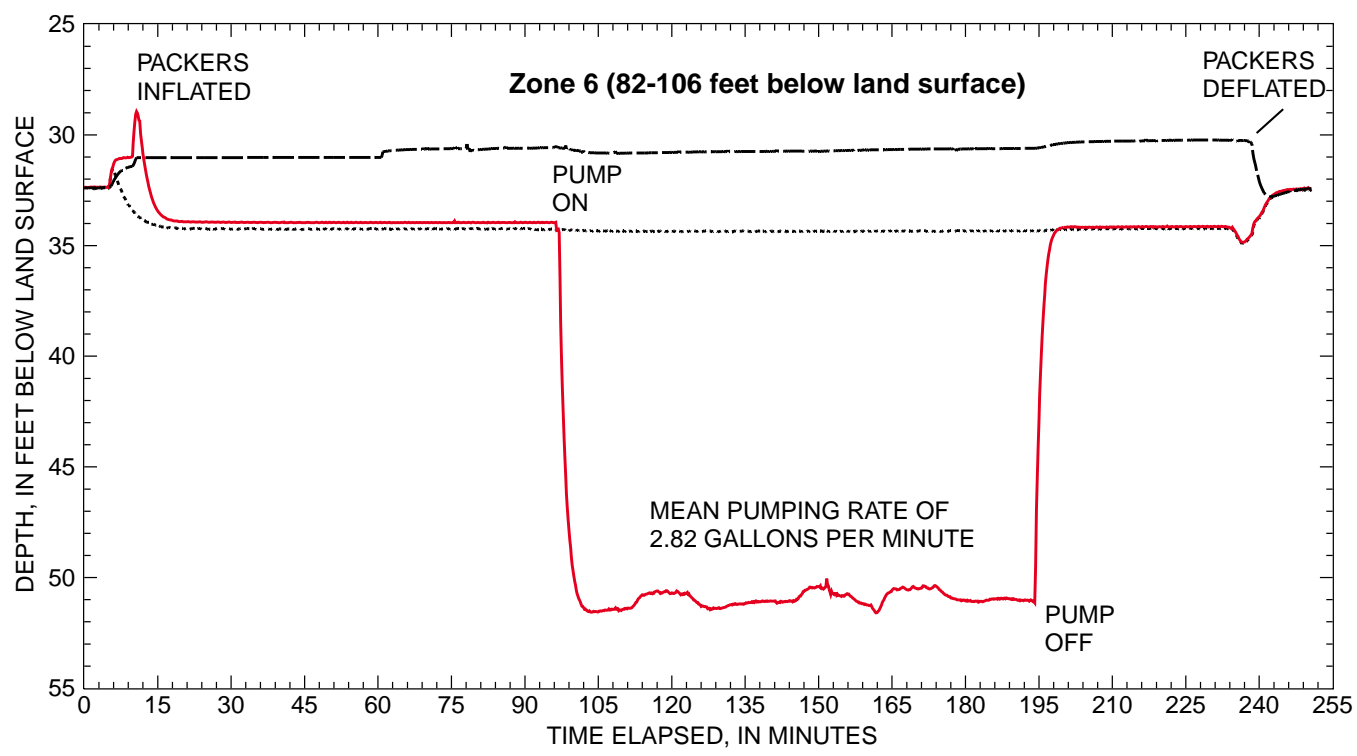

\section{EXPLANATION}

........ WATER LEVEL ABOVE THE ISOLATED INTERVAL

WATER LEVEL IN THE ISOLATED INTERVAL

WATER LEVEL BELOW THE ISOLATED INTERVAL

Figure 38. Depth to water above isolated interval, in isolated interval, and below isolated interval before, during, and after pumping for test of isolated interval zone 6 (between 82 and 106 feet below land surface) in well Mg-174 (Clearline 2), North Penn Area 7 Superfund site, Upper Gwynedd Township, Montgomery County, Pa., September 21, 2001. 
Table 25. Depths, water levels, and specific capacity of aquifer intervals isolated by packers for well MG-174 (Clearline 2), North Penn Area 7 Superfund site, Upper Gwynedd Township, Montgomery County, Pa.

[ft bls, feet below land surface; ft, feet; gal/min, gallons per minute; min, minutes; (gal/min)/ft, gallons per minute per foot; $\mathrm{ft}^{2} / \mathrm{d}$, feet squared per day; --, no data]

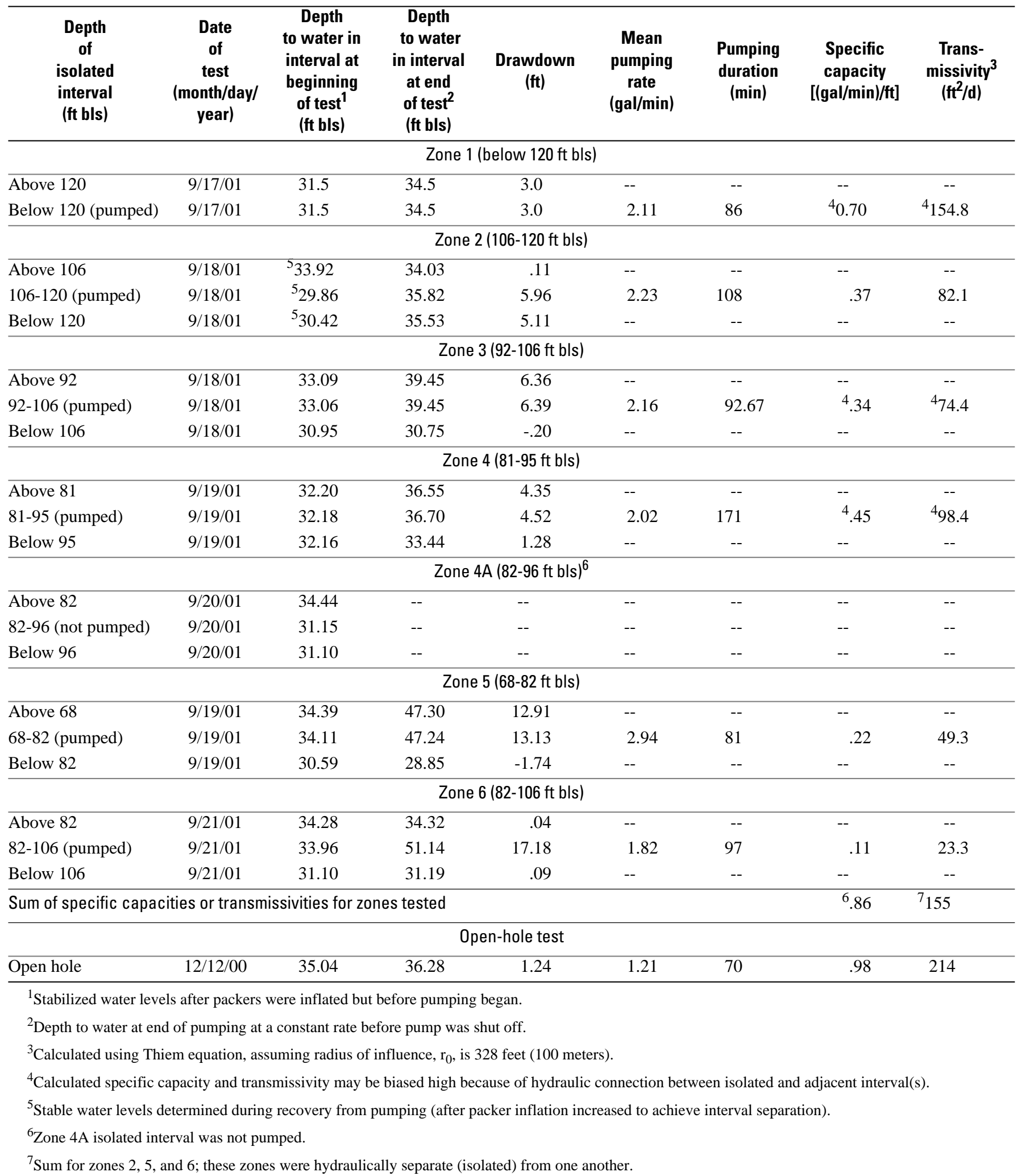




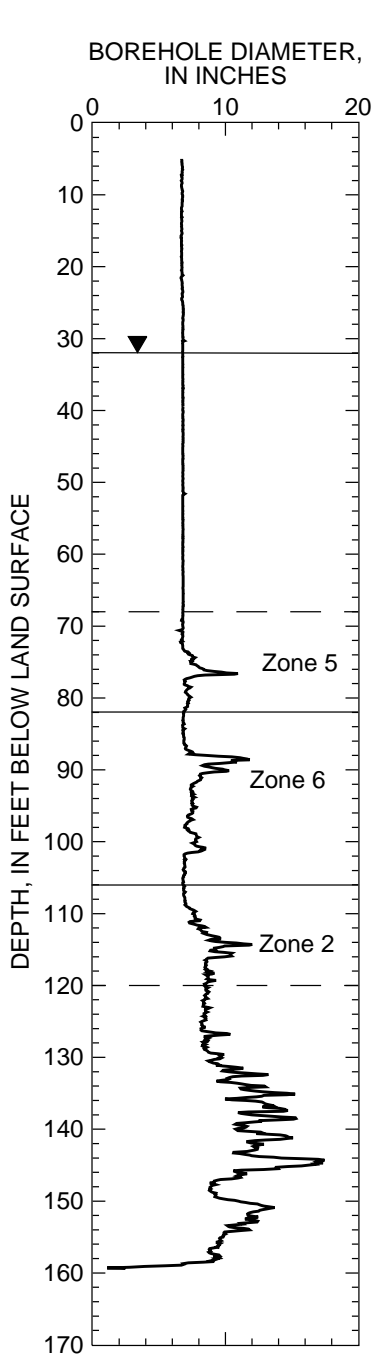

SPECIFIC CAPACITY
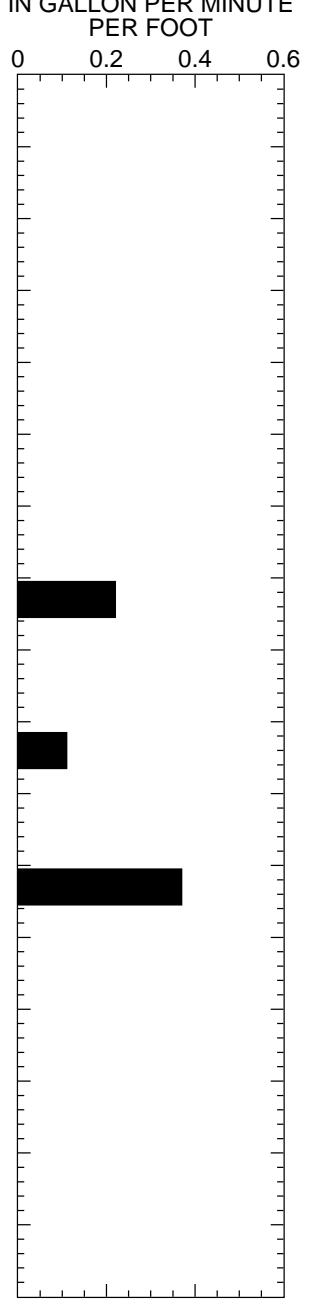

CONCENTRATION IN MICROGRAMS PER LITER

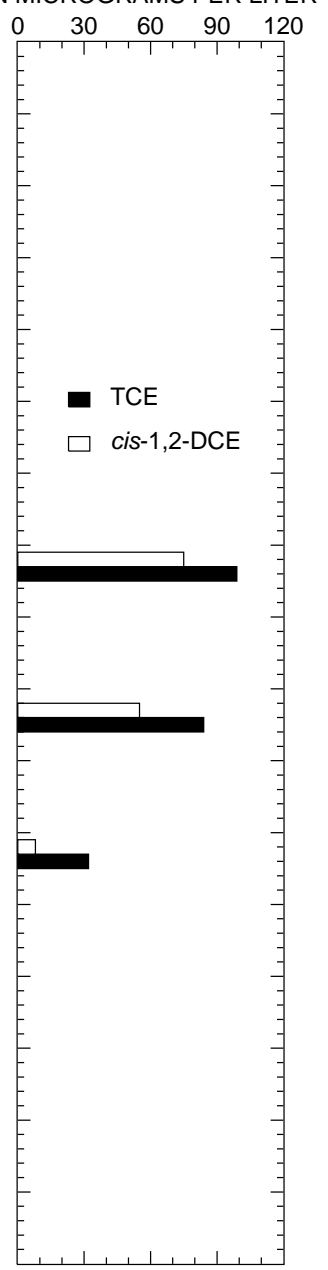

CONCENTRATION IN MICROGRAMS PER LITER

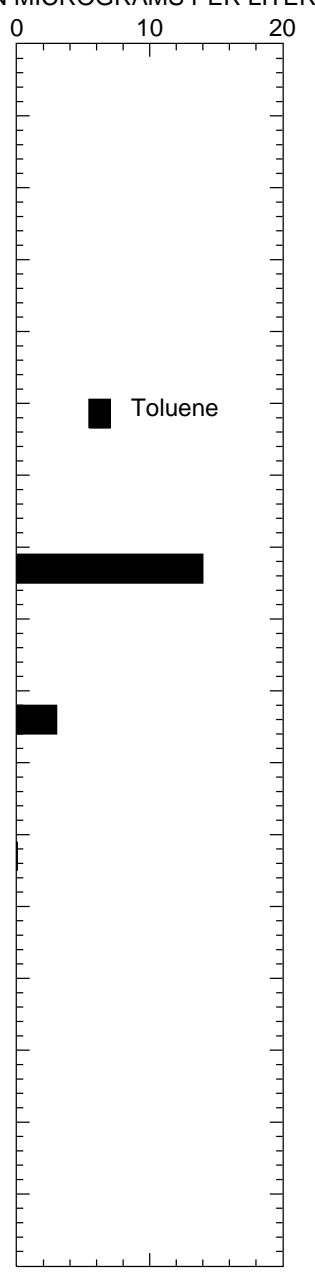

EXPLANATION

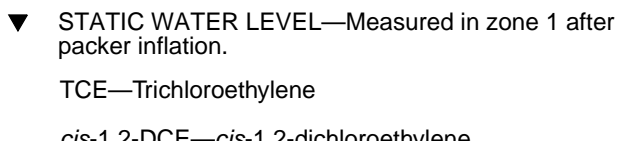

cis-1,2-DCE-cis-1.2-dichloroethylene

Figure 39. Caliper log showing diameter and location, specific capacity, and water quality of isolated intervals for well MG-174 (Clearline 2), North Penn Area 7 Superfund site, Upper Gwynedd Township, Montgomery County, Pa. Dashed line at bottom of zone 2 and top of zone 5 indicates hydraulic connection with adjacent interval. Depicted water quality includes concentrations of trichloroethylene, cis-1,2dichloroethylene, and toluene.

Physical and chemical properties of water pumped from isolated intervals and measured near the end of pumping are listed in table 26. The $\mathrm{pH}$, dissolved-oxygen concentration, temperature, and specific conductance of water from the isolated intervals in well MG-174 were similar (table 26). In general, the $\mathrm{pH}$ was near neutral (ranging from 7.26 to $7.51 \mathrm{pH}$ units) and dissolved-oxygen concentrations were low (0.5 mg/L or less). Results of laboratory analyses (table 27) indicate concentrations of VOCs differ in water samples col- lected from the isolated intervals. More compounds and higher concentrations of VOCs were detected in samples from intervals above $106 \mathrm{ft}$ bls than in samples from intervals below that depth (fig. 39; table 27). TCE, cis-1,2-DCE, and toluene were the compounds measured in the highest concentrations. 
Table 26. Inorganic water-quality constituents and physical properties for samples collected from isolated intervals in well MG-174 (Clearline 2), North Penn Area 7 Superfund site, Upper Gwynedd Township, Montgomery County, $\mathrm{Pa}$.

[ft bls, feet below land surface; mg/L, milligrams per liter; ${ }^{\circ} \mathrm{C}$, degrees Celsius, $\mu \mathrm{S} / \mathrm{cm}$ at $25{ }^{\circ} \mathrm{C}$, microsiemens per centimeter at 25 degrees Celsius; --, no data]

\begin{tabular}{cccccccc}
\hline Zone & $\begin{array}{c}\text { Depth of } \\
\text { isolated } \\
\text { interval } \\
\text { (ft bls) }\end{array}$ & $\begin{array}{c}\text { Date } \\
\text { sampled } \\
\text { (month/day/ } \\
\text { year) }\end{array}$ & Time & $\begin{array}{c}\text { pH } \\
\text { (standard } \\
\text { units) }\end{array}$ & $\begin{array}{c}\text { Dissolved } \\
\text { oxygen } \\
(\mathbf{m g} / \mathbf{L})\end{array}$ & $\begin{array}{c}\text { Water } \\
\text { temperature } \\
\left({ }^{\circ} \mathbf{C}\right)\end{array}$ & $\begin{array}{c}\text { Specific } \\
\text { conductance } \\
(\mu \mathbf{S} / \mathbf{c m} \text { at } \\
\left.\mathbf{2 5}{ }^{\circ} \mathbf{C}\right)\end{array}$ \\
\hline 1 & Below 120 & $9 / 17 / 01$ & 1720 & 7.48 & 0.5 & 14.0 & 479 \\
2 & $106-120$ & $9 / 18 / 01$ & 1250 & -- & -- & 14.4 & 481 \\
3 & $92-106$ & $9 / 18 / 01$ & -- & -- & -- & -- & -- \\
4 & $81-95$ & $9 / 19 / 01$ & 1321 & 7.41 & -3 & 13.9 & 480 \\
$4 \mathrm{~A}$ & $82-96$ & $9 / 20 / 01$ & -- & -- & -- & -- & -- \\
5 & $68-82$ & $9 / 19 / 01$ & 1755 & 7.51 & .5 & 14.7 & 474 \\
6 & $82-106$ & $9 / 21 / 01$ & 1603 & 7.26 & .4 & 14.7 & 482 \\
\hline
\end{tabular}

Table 27. Selected volatile organic compound concentrations in water samples from isolated intervals in well MG-174 (Clearline 2), North Penn Area 7 Superfund site, Upper Gwynedd Township, Montgomery County, Pa. (Laboratory results provided by CDM Federal Programs Corporation.)

[ft bls, feet below land surface; $\mu \mathrm{g} / \mathrm{L}$, micrograms per liter; $\mathrm{ND}$, not detected; $\mathrm{D}$, detected; J, compound present—reported value may not be accurate or precise; $\mathrm{B}$, not detected substantially above the level reported in laboratory or field blanks; E, estimated]

\begin{tabular}{|c|c|c|c|c|c|c|c|c|c|c|c|c|}
\hline Zone $^{1}$ & $\begin{array}{c}\text { Depth of } \\
\text { isolated } \\
\text { interval } \\
\text { (ft bls) }\end{array}$ & $\begin{array}{c}\text { Date } \\
\text { sampled } \\
\text { (month/ } \\
\text { day/year) }\end{array}$ & $\begin{array}{c}\text { Tetra- } \\
\text { chloro- } \\
\text { ethylene } \\
(\mu \mathrm{g} / \mathrm{L})\end{array}$ & $\begin{array}{l}\text { Trichloro- } \\
\text { ethylene } \\
(\mu \mathrm{g} / \mathrm{L})\end{array}$ & $\begin{array}{c}\text { cis-1,2- } \\
\text { Dichloro- } \\
\text { ethylene } \\
(\mu \mathrm{g} / \mathrm{L})\end{array}$ & $\begin{array}{c}\text { 1,1- } \\
\text { Dichloro- } \\
\text { ethylene } \\
(\mu \mathrm{g} / \mathrm{L})\end{array}$ & $\begin{array}{c}\text { 1,1,1- } \\
\text { Trichloro- } \\
\text { ethane } \\
(\mu \mathrm{g} / \mathrm{L})\end{array}$ & $\begin{array}{c}\text { Toluene } \\
\text { ( } \mu \mathrm{g} / \mathrm{L})\end{array}$ & $\begin{array}{l}\text { Trichloro- } \\
\text { fluoro- } \\
\text { methane } \\
(\mu \mathrm{g} / \mathrm{L})\end{array}$ & $\begin{array}{c}\text { Methyl- } \\
\text { ene } \\
\text { chloride } \\
(\mu \mathrm{g} / \mathrm{L})\end{array}$ & $\begin{array}{c}\text { Bromo- } \\
\text { form } \\
(\mu \mathrm{g} / \mathrm{L})\end{array}$ & $\begin{array}{c}\text { Chloro- } \\
\text { methane } \\
(\mu \mathrm{g} / \mathrm{L})\end{array}$ \\
\hline 1 & Below 120 & $9 / 17 / 01$ & ND & $43 \mathrm{D}$ & $8 \mathrm{D}$ & ND & ND & $2 \mathrm{DJ}$ & ND & $2 \mathrm{DJB}$ & $3 \mathrm{DB}$ & ND \\
\hline 2 & $106-120$ & $9 / 18 / 01$ & ND & $32 \mathrm{D}$ & $8 \mathrm{D}$ & ND & ND & ND & ND & $2 \mathrm{DJ}$ & $3 \mathrm{D}$ & ND \\
\hline 3 & $92-106$ & $9 / 18 / 01$ & ND & $43 \mathrm{D}$ & $8 \mathrm{D}$ & ND & ND & $8 \mathrm{D}$ & ND & $2 \mathrm{DJB}$ & $3 \mathrm{DB}$ & ND \\
\hline $4(1203)$ & $81-95$ & $9 / 19 / 01$ & 0.5 & $46 \mathrm{E}$ & 10 & ND & ND & 3 & $0.2 \mathrm{~J}$ & $0.2 \mathrm{~J}$ & 0.6 & $0.3 \mathrm{~J}$ \\
\hline $\begin{array}{l}4(1203) \\
\text { duplicate }\end{array}$ & $81-95$ & $9 / 19 / 01$ & ND & $48 \mathrm{D}$ & $9 \mathrm{D}$ & ND & ND & $3 \mathrm{D}$ & ND & 5. D & 3. D & ND \\
\hline $4(1320)$ & $81-95$ & $9 / 19 / 01$ & .5 & 48. E & 13. & ND & ND & 6. & $.2 \mathrm{~J}$ & $.4 \mathrm{~J}$ & 6 & $.2 \mathrm{~J}$ \\
\hline $\begin{array}{l}4 \text { (1320) } \\
\text { duplicate }\end{array}$ & $81-95$ & $9 / 19 / 01$ & ND & 50. D & 11. D & 1. DJ & ND & 6. D & ND & 5. D & 3. D & ND \\
\hline $4 \mathrm{~A}$ & $82-96$ & $9 / 20 / 01$ & .7 & 84. & 55. E & 2. & 0.5 & 3. & ND & .6 & .8 & $.3 \mathrm{~J}$ \\
\hline 5 & $68-82$ & $9 / 19 / 01$ & .7 & 99. E & 75. E & 2. & $.3 \mathrm{~J}$ & 14. & $.4 \mathrm{~J}$ & 1. & .5 & ND \\
\hline 6 & $82-106$ & $9 / 21 / 01$ & .7 & 84. E & 55. E & 2. & .5 & 3. & .6 & .6 & .8 & $.3 \mathrm{~J}$ \\
\hline
\end{tabular}

\footnotetext{
${ }^{1}$ Time of sampling in parentheses as noted.
} 


\section{Well MG-175 (Spra-Fin 1)}

Geophysical logging of well MG-175 indicated probable water-bearing zones in the intervals between 70 and 90 and 90 and $103 \mathrm{ft}$ bls. The water-bearing zones correspond to fractures detected in these intervals on the caliper log (fig. 7), and when the well was pumped for heatpulse-flowmeter measurements, both intervals produced similar amounts of water. Three intervals (zones 1-3, table 28) were subsequently selected for isolation on the basis of geophysical logging results and direct observation of borehole condition by borehole video survey. The spacing between the mid-points of the packers was $13 \mathrm{ft}$ for all zones.

Table 28. Isolated intervals tested in well MG-175 (Spra-Fin 1), North Penn Area 7 Superfund site, Upper Gwynedd Township, Montgomery County, Pa., April 2002.

[ft bls, feet below land surface]

\begin{tabular}{ccc}
\hline Zone & $\begin{array}{c}\text { Depth of } \\
\text { isolated } \\
\text { interval } \\
\text { (ft bls) }\end{array}$ & $\begin{array}{c}\text { Date } \\
\text { of } \\
\text { test } \\
\text { (month/day/year) }\end{array}$ \\
\hline 1 & Above 72 & $4 / 23 / 02$ \\
2 & $72-85$ & $4 / 22 / 02$ \\
3 & Below 85 & $4 / 22 / 02$ \\
\hline
\end{tabular}

The test of zone 1 indicated the interval above $72 \mathrm{ft}$ bls was slightly connected to the interval below $72 \mathrm{ft}$ bls as noted by the slight response to pumping stress observed in the lower (nonpumped) interval (fig. 40). The test of zone 2 indicated the pumped interval at $72-85 \mathrm{ft}$ bls was isolated hydraulically from the intervals above and below (fig. 40). The test of zone 3 indicated that the interval below $85 \mathrm{ft}$ bls was isolated hydraulically from the interval above $85 \mathrm{ft}$ bls (fig. 41).
Tests of zones 2 and 3 showed that neither of these intervals were connected hydraulically either inside of the borehole as the result of inadequate packer seal or outside of the borehole as the result of aquifer properties. The test of zone 1 showed a slight hydraulic connection between the pumped interval (above $72 \mathrm{ft}$ bls) and the lower isolated interval (below $72 \mathrm{ft}$ bls). The response to pumping stress in an isolated interval adjacent to a pumped interval, as observed in zone 1, is indicative of either slight leakage around a packer or through fractures in the aquifer. Head separation after packer inflation and (or) no response in adjacent zones to pumping stress, as observed in zones 2 and 3, indicates low, or no, hydraulic connection between isolated intervals. Head separation upon packer inflation did not occur in any of the tested zones, indicating little or no vertical gradient and, subsequently, no vertical flow within the borehole. The absence of vertical flow measured in the borehole under nonpumping conditions at the time of geophysical logging substantiates these findings.

Results from the isolation tests indicate the presence of at least three hydraulically isolated intervals in the well: above $72 \mathrm{ft}$ bls (zone 1 test), $72-85 \mathrm{ft}$ bls (zone 2 test), and below $85 \mathrm{ft}$ bls (zone 3 test). The interval below $85 \mathrm{ft}$ bls has a higher specific capacity than the intervals above it (fig. 42; table 29). These data indicate that the interval below $85 \mathrm{ft}$ bls should be more productive than the upper intervals; however, geophysical logging provided contradictory data that showed the intervals between 70 and $90 \mathrm{ft}$ bls and 90 and $103 \mathrm{ft}$ bls produced similar amounts of water when pumped for heatpulse-flowmeter measurements. The specific capacity computed for the entire well (open hole) during geophysical logging produced a higher value $[3.59(\mathrm{gal} / \mathrm{min}) / \mathrm{ft}]$ than the sum of the specific capacities for the productive zones determined by isolation tests [2.41 (gal/min)/ft] (table 29). Hydraulic influences (outside pumping stresses) from the adjacent region may have altered background conditions during geophysical logging as compared to during the isolation tests; thereby, possibly accounting for the variation observed between the two data sets. 

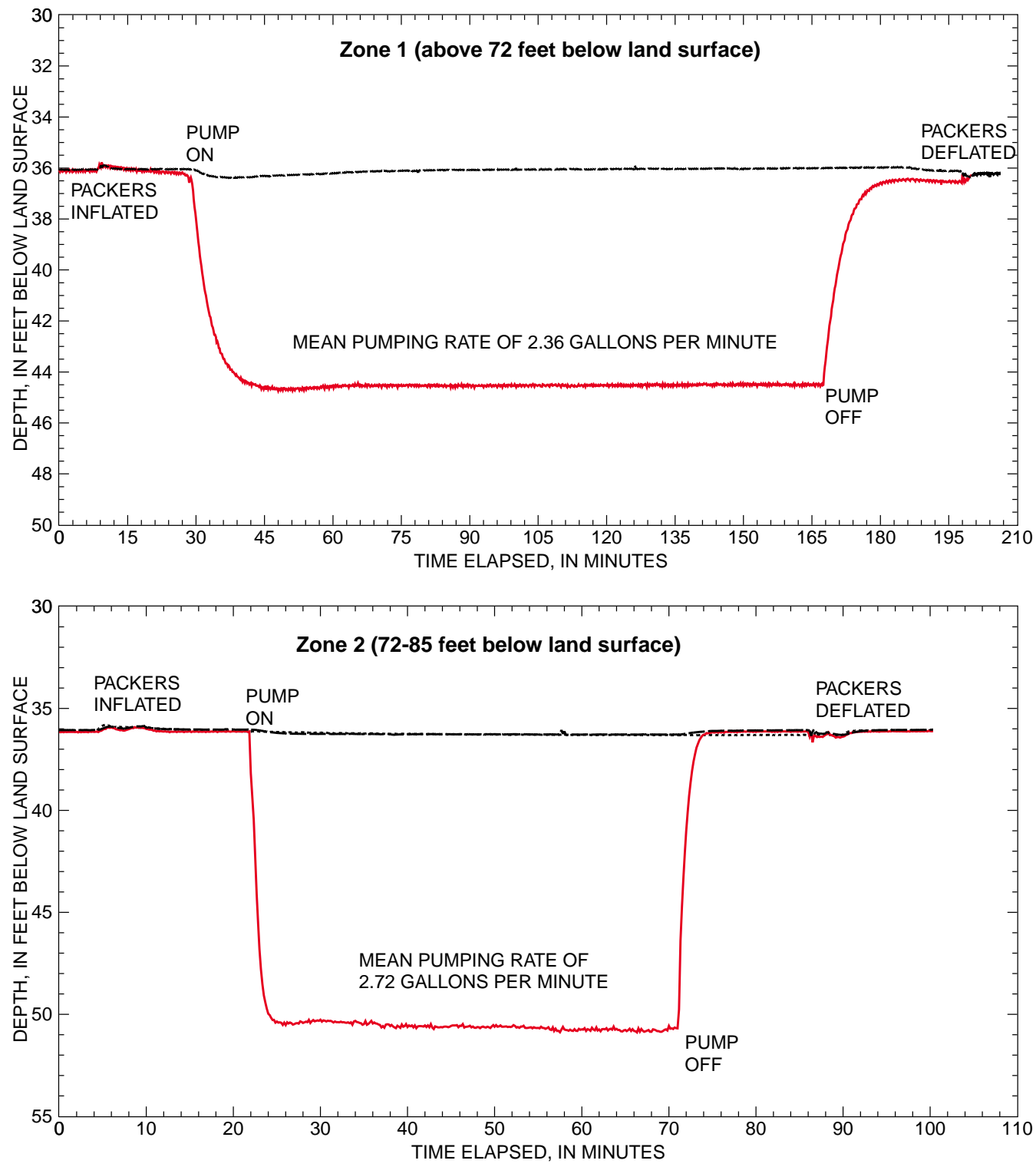

EXPLANATION

WATER LEVEL ABOVE THE ISOLATED INTERVAL

WATER LEVEL IN THE ISOLATED INTERVAL

WATER LEVEL BELOW THE ISOLATED INTERVAL

Figure 40. Depth to water above isolated interval, in isolated interval, and below isolated interval before, during, and after pumping for tests of isolated intervals zone 1 (above 72 feet below land surface) and zone 2 (between 72 and 85 feet below land surface) in well MG-175 (Spra-Fin 1), North Penn Area 7 Superfund site, Upper Gwynedd Township, Montgomery County, Pa., April 22-23, 2002. 


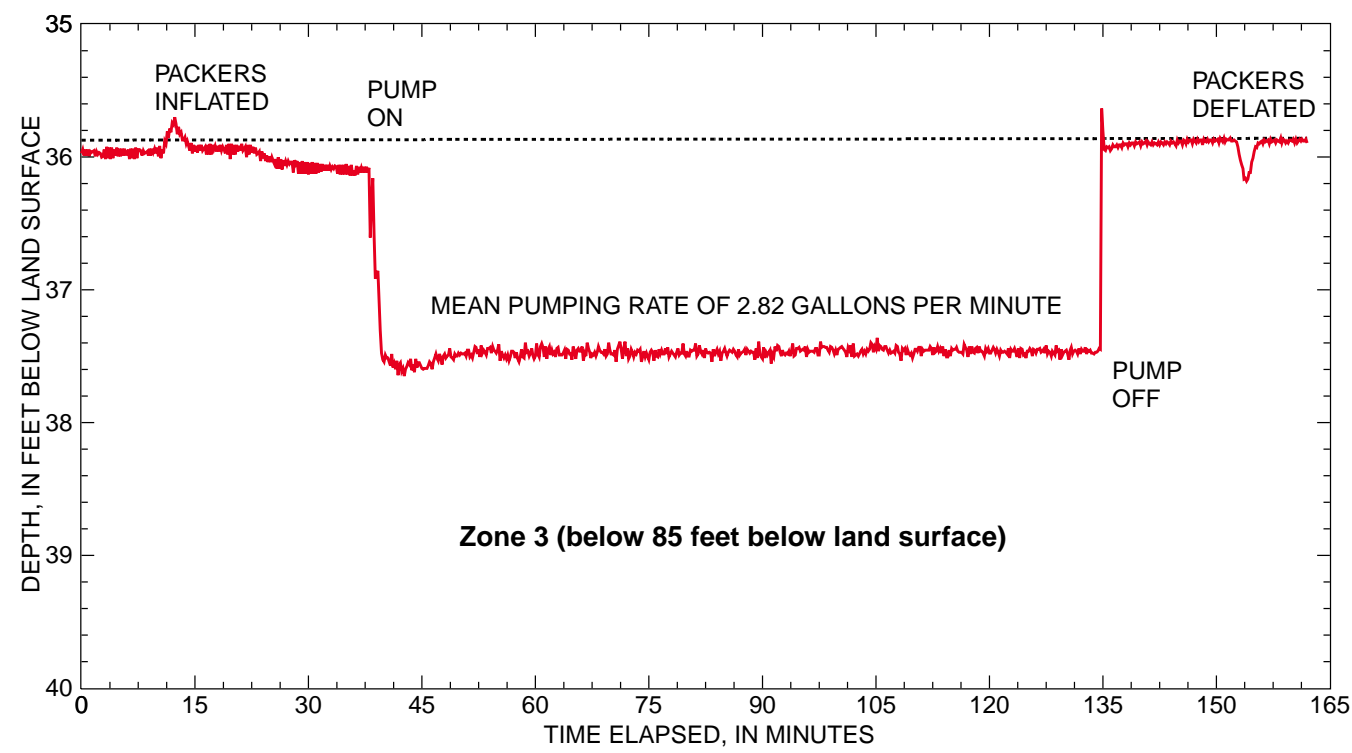

EXPLANATION

WATER LEVEL ABOVE THE ISOLATED INTERVAL

WATER LEVEL IN THE ISOLATED INTERVAL

Figure 41. Depth to water above isolated interval and in isolated interval before, during, and after pumping for test of isolated interval zone 3 (below 85 feet below land surface) in well MG-175

(Spra-Fin 1), North Penn Area 7 Superfund site, Upper Gwynedd Township, Montgomery County, Pa., April 22, 2002.

Table 29. Depths, water levels, and specific capacity of aquifer intervals isolated by packers for well MG-175 (Spra-Fin 1), North Penn Area 7, Upper Gwynedd Township, Montgomery County, Pa.

[ft bls, feet below land surface; ft, feet; gal/min, gallons per minute; min, minutes; (gal/min)/ft, gallons per minute per foot; ft ${ }^{2} / \mathrm{d}$, feet squared per day; --, no data]

\begin{tabular}{|c|c|c|c|c|c|c|c|c|}
\hline $\begin{array}{l}\text { Depth } \\
\text { of } \\
\text { isolated } \\
\text { interval } \\
\text { (ft bls) }\end{array}$ & $\begin{array}{c}\text { Date } \\
\text { of } \\
\text { test } \\
\text { (month/day/ } \\
\text { year) }\end{array}$ & $\begin{array}{c}\text { Depth } \\
\text { to water in } \\
\text { interval at } \\
\text { beginning } \\
\text { of test }{ }^{1} \\
\text { (ft bls) }\end{array}$ & $\begin{array}{c}\text { Depth } \\
\text { to water in } \\
\text { interval } \\
\text { at end } \\
\text { of test }^{2} \\
\text { (ft bls) }\end{array}$ & $\begin{array}{c}\text { Drawdown } \\
\text { (ft) }\end{array}$ & $\begin{array}{c}\text { Mean } \\
\text { pumping } \\
\text { rate } \\
\text { (gal/min) }\end{array}$ & $\begin{array}{l}\text { Pumping } \\
\text { duration } \\
\text { (min) }\end{array}$ & $\begin{array}{c}\text { Specific } \\
\text { capacity } \\
{[(\text { gal/min }) / f t]}\end{array}$ & $\begin{array}{l}\text { Trans- } \\
\text { missivity } \\
\left(\mathrm{ft}^{2} / \mathrm{d}\right)\end{array}$ \\
\hline \multicolumn{9}{|c|}{ Zone 1 (above $72 \mathrm{ft}$ bls) } \\
\hline Above 72 (pumped) & $4 / 23 / 02$ & 36.37 & 44.51 & 8.14 & 2.36 & 141 & 0.29 & 63.8 \\
\hline Below 72 & $4 / 23 / 02$ & 36.08 & 36.00 & -.08 & -- & -- & -- & -- \\
\hline \multicolumn{9}{|c|}{ Zone 2 (72-85 ft bls) } \\
\hline Above 72 & $4 / 22 / 02$ & 36.14 & 36.30 & .16 & -- & -- & -- & -- \\
\hline 72-85 (pumped) & $4 / 22 / 02$ & 36.13 & 50.69 & 14.56 & 2.72 & 49 & .19 & 42.3 \\
\hline Below 85 & $4 / 22 / 02$ & 36.13 & 36.31 & .18 & -- & -- & -- & -- \\
\hline \multicolumn{9}{|c|}{ Zone 3 (below $85 \mathrm{ft}$ bls) } \\
\hline Above 85 & $4 / 22 / 02$ & 35.87 & 35.86 & -.01 & -- & -- & -- & -- \\
\hline Below 85 (pumped) & $4 / 22 / 02$ & 35.99 & 37.45 & 1.46 & 2.82 & 97 & 1.93 & 425 \\
\hline Sum of specific capac & ities or transmi & sivities for zo & es tested & & & & 2.41 & 531 \\
\hline \multicolumn{9}{|c|}{ Open-hole tests } \\
\hline Open hole & $3 / 27 / 02$ & 38.83 & 39.12 & .29 & 1.04 & 22.5 & 3.59 & 747 \\
\hline
\end{tabular}




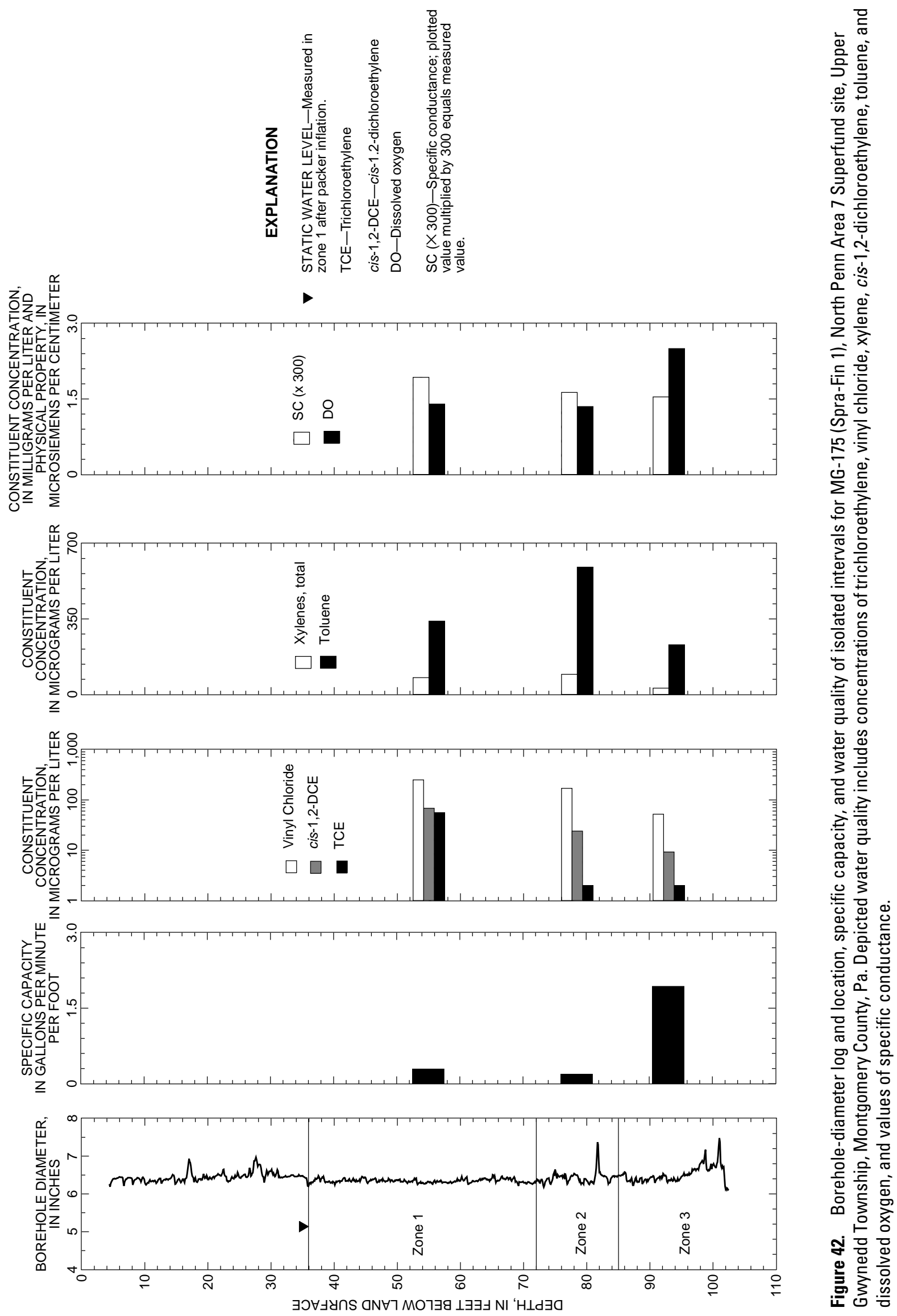


Physical and chemical properties of water pumped from the isolated intervals and measured near the end of pumping are listed in table 30 . The $\mathrm{pH}$, dissolved-oxygen concentration, temperature, and specific conductance of water from the isolated intervals in well MG-175 were slightly different in each zone. Compared to water from other zones, water from zone 1 had a slightly higher temperature $\left(14.3^{\circ} \mathrm{C}\right)$ and specific conductance $(578 \mu \mathrm{S} / \mathrm{cm})$, and water from zone 3 had a slightly higher dissolved-oxygen concentration (2.5 mg/L) (table 30). Results of laboratory analyses (table 31 ) indicate differences in
VOC concentrations among water samples collected from the isolated intervals. More compounds and higher concentrations of VOCs were detected in samples from zones above $85 \mathrm{ft}$ bls than below that depth (fig. 42; table 31). Cis-1,2-DCE, tolulene, and vinyl chloride were the compounds measured in the highest concentrations. Water from the shallowest interval tested, above $72 \mathrm{ft}$ bls (zone 1), had higher concentrations of TCE, cis-1,2-DCE, and vinyl chloride than water from deeper zones below $72 \mathrm{ft}$ bls. Toluene concentrations were greatest in water from the interval between 72 and $85 \mathrm{ft}$ bls (zone 2).

Table 30. Inorganic water-quality constituents and physical properties for samples collected from isolated intervals in well MG-175 (Spra-Fin 1), North Penn Area 7 Superfund site, Upper Gwynedd Township, Montgomery County, Pa.

[ft bls, feet below land surface; mg/L, milligrams per liter; ${ }^{\circ} \mathrm{C}$, degrees Celsius, $\mu \mathrm{S} / \mathrm{cm}$ at $25{ }^{\circ} \mathrm{C}$, microsiemens per centimeter at 25 degrees $\mathrm{Celsius} ; \mathrm{Fe}^{2+}$, ferrous iron; Fe, iron]

\begin{tabular}{|c|c|c|c|c|c|c|c|c|c|c|c|c|}
\hline Zone & $\begin{array}{c}\text { Depth } \\
\text { of isolated } \\
\text { interval } \\
\text { (ft bls) }\end{array}$ & $\begin{array}{c}\text { Date } \\
\text { sampled } \\
\text { (month/ } \\
\text { day/year) }\end{array}$ & Time & $\begin{array}{c}\text { pH } \\
\text { (standard } \\
\text { units) }\end{array}$ & $\begin{array}{c}\text { Dis- } \\
\text { solved } \\
\text { oxygen } \\
\text { (mg/L) }\end{array}$ & $\begin{array}{c}\text { Temper- } \\
\text { ature } \\
\left({ }^{\circ} \mathrm{C}\right)\end{array}$ & $\begin{array}{c}\text { Specific } \\
\text { conduct- } \\
\text { ance } \\
(\mu \mathrm{S} / \mathrm{cm} \text { at } \\
\left.25^{\circ} \mathrm{C}\right)\end{array}$ & $\begin{array}{l}\text { Alkalinity } \\
\text { (mg/L) }\end{array}$ & $\begin{array}{l}\text { Sulfide } \\
\text { (mg/L) }\end{array}$ & $\begin{array}{l}\text { Sulfate } \\
\text { (mg/L) }\end{array}$ & $\begin{array}{c}\mathrm{Fe}^{2+} \\
(\mathrm{mg} / \mathrm{L})\end{array}$ & $\begin{array}{c}\text { Fe, } \\
\text { total } \\
(\mathrm{mg} / \mathrm{L})\end{array}$ \\
\hline 1 & Above 72 & $4 / 24 / 02$ & 1110 & 7.11 & 1.4 & 14.3 & 578 & 203.6 & 0.006 & 37 & 0.6 & 0.74 \\
\hline 2 & $72-85$ & $4 / 23 / 02$ & 1032 & 7.25 & ${ }^{1} 1.2$ & 13.1 & 489 & 139.8 & .004 & 40 & .43 & .65 \\
\hline 3 & Below 85 & $4 / 22 / 02$ & 1435 & 7.42 & 22.5 & 13.8 & 461 & 132.7 & .002 & 38 & .06 & .17 \\
\hline
\end{tabular}

${ }^{1}$ Estimated range: $1.2-1.5 \mathrm{mg} / \mathrm{L}$. Starting and ending sodium thiosulfate amounts used in titration to determine concentration are not precise.

${ }^{2}$ Last $\mathrm{pH}$ reading not accurately recorded.

Table 31. Selected volatile organic compound concentrations in water samples from isolated intervals in well MG-175 (Spra-Fin 1), North Penn Area 7 Superfund site, Upper Gwynedd Township, Montgomery County, Pa. (Laboratory results provided by CDM Federal Programs Corporation.)

[ft bls, feet below land surface; $\mu \mathrm{g} / \mathrm{L}$, micrograms per liter; >, greater than; J, compound present-reported value may not be accurate or precise; ND, not detected]

\begin{tabular}{|c|c|c|c|c|c|c|c|c|}
\hline Zone & $\begin{array}{l}\text { Depth } \\
\text { (ft bls) }\end{array}$ & $\begin{array}{c}\text { Date } \\
\text { sampled }\end{array}$ & $\begin{array}{c}\text { Trichloro- } \\
\text { ethylene } \\
(\mu \mathrm{g} / \mathrm{L})\end{array}$ & $\begin{array}{c}\text { cis-1,2- } \\
\text { Dichloro- } \\
\text { ethylene } \\
(\mu \mathrm{g} / \mathrm{L})\end{array}$ & $\begin{array}{c}\text { Toluene } \\
\text { ( } \mu \mathrm{g} / \mathrm{L})\end{array}$ & $\begin{array}{c}\text { Methylene } \\
\text { chloride } \\
\text { ( } \mu \mathrm{g} / \mathrm{L})\end{array}$ & $\begin{array}{c}\text { Vinyl } \\
\text { chloride } \\
\text { ( } \mu \mathrm{g} / \mathrm{L})\end{array}$ & $\begin{array}{c}\text { Xylenes } \\
\text { ( } \mu \mathrm{g} / \mathrm{L})\end{array}$ \\
\hline 1 & Above 72 & $4 / 24 / 02$ & 56 & $>680 \mathrm{~J}$ & $>340 \mathrm{~J}$ & $4 \mathrm{~J}$ & $>250 \mathrm{~J}$ & 78 \\
\hline 2 & $72-85$ & $4 / 23 / 02$ & $2 \mathrm{~J}$ & $>240$ & $>590$ & $2 \mathrm{~J}$ & $170 \mathrm{~J}$ & 93 \\
\hline 3 & Below 85 & $4 / 22 / 02$ & $2 \mathrm{~J}$ & 92 & $>230$ & ND & $52 \mathrm{~J}$ & 29 \\
\hline 3 duplicate & Below 85 & $4 / 22 / 02$ & $1 \mathrm{~J}$ & 110 & $>240$ & ND & $51 \mathrm{~J}$ & 36 \\
\hline
\end{tabular}




\section{Well MG-202 (L-22)}

Geophysical logging of well MG-202 indicated probable water-bearing zones in the intervals between 53 and 130, 150 and 170, 212 and 223, and 224 and $260 \mathrm{ft}$ bls. The water-bearing zones correspond to fractures detected in these intervals on the caliper log (fig. 9). When the well was pumped for heatpulse-flowmeter measurements, the interval between 142 and $170 \mathrm{ft}$ bls apparently was the most productive. During the time period geophysical logging and isolation tests were conducted by USGS, construction on the well house was being done. Time restraints resulting from the construction schedule limited the total possible zones that could be isolated. Intervals below approximately $320 \mathrm{ft}$ bls were not isolated because all major water-bearing zones were above that depth and also because of the reduction in borehole diameter from 12 to $10 \mathrm{in}$. at that depth. Slight deviations from vertical are very common in most wells; this deviation causes the packer assembly to press against the borehole wall (foot wall) and makes it impossible to lower the packers past the "step" caused by the reduction in borehole size. Four intervals (zones 1-4, table 32) were subsequently selected for isolation based on time constraints, results of geophysical logging, and direct observation of borehole condition by borehole video survey. The spacing between the mid-points of the packers was $23.5 \mathrm{ft}$ for all zones.

Table 32. Isolated intervals tested in well MG-202 (L-22), North Penn Area 7 Superfund site, Upper Gwynedd Township, Montgomery County, Pa., December 2001.

[ft bls, feet below land surface]

\begin{tabular}{ccc}
\hline Zone & $\begin{array}{c}\text { Depth } \\
\text { of } \\
\text { isolated } \\
\text { interval } \\
\text { (ft bls) }\end{array}$ & $\begin{array}{c}\text { Date } \\
\text { of } \\
\text { test } \\
\text { (month/day/year) }\end{array}$ \\
\hline 1 & $107-130.5$ & $12 / 21 / 01$ \\
2 & $147-170.5$ & $12 / 19 / 01$ \\
3 & $212-235.5$ & $12 / 20 / 01$ \\
4 & $233-256.5$ & $12 / 19 / 01$ \\
\hline
\end{tabular}

The test of zone 1 (107-130.5 ft bls) showed no head (water level) separation between the isolated interval and the interval above $107 \mathrm{ft}$ bls (fig. 43), indicating the interval above $107 \mathrm{ft}$ bls is connected hydraulically to the interval between 107 and $130.5 \mathrm{ft}$ bls. The interval below $130.5 \mathrm{ft}$ bls appears only slightly connected to the intervals above, as shown by head separation between this lower interval and the two intervals above it; also, water levels in the interval below
$130.5 \mathrm{ft}$ bls had only a very slight response to pumping stress within the 107-130.5 ft bls interval. The head separation observed after packer inflation in zone 1 showed the upper and packed intervals had a higher head than observed in the lower interval, indicating downward vertical gradient and, consequently, potential for downward flow through the zone.

The test of zone 2 (147-170.5 ft bls) showed appreciable head separation between all three intervals upon packer inflation (fig. 43). Also, the intervals above 147 and below $170.5 \mathrm{ft}$ bls did not respond to pumping stress within the interval between 147 and $170.5 \mathrm{ft}$ bls. The noted head separation and lack of response to pumping in intervals adjacent to the pumped interval indicated all three intervals in zone 2 were isolated hydraulically. The observed head separation indicated downward vertical gradient and the potential for downward flow within the borehole through zone 2 .

The test of zone 3 (212-235.5 ft bls) showed head separation between all intervals upon packer inflation (fig. 44). The initial head separation observed between the intervals 212$235.5 \mathrm{ft}$ bls and below $235.5 \mathrm{ft}$ bls, when only the lower packer was inflated, probably reflected the large downward vertical gradient above $235 \mathrm{ft}$ bls. However, the head convergence between the intervals 212-235.5 ft bls and below $235.5 \mathrm{ft}$ bls subsequent to upper packer inflation indicated hydraulic connection outside of the borehole between these two intervals. The hydraulic connection outside the borehole between the interval 212-235 ft bls and below also was indicated by the response in the interval below $235.5 \mathrm{ft}$ bls to pumping in the interval of 212-235.5 ft bls. The zone 3 test data showed the interval above $212 \mathrm{ft}$ bls is isolated hydraulically from the lower two intervals and there is a hydraulic connection between the lower two intervals (212-235.5 and below $235.5 \mathrm{ft}$ bls). In addition, the post-inflation but pre-pumping head separation between the interval above $212 \mathrm{ft}$ bls and intervals below indicated a downward vertical gradient, consistent with the downward borehole flow to receiving zones between 212 and $234 \mathrm{ft}$ bls observed during geophysical logging.

The test of zone 4 (233-256.5 ft bls) showed head separation between the isolated interval and adjacent intervals after packer inflation (fig. 44). The intervals above $233 \mathrm{ft}$ bls and below $256.5 \mathrm{ft}$ bls did not respond to pumping stress within the interval between 233-256.5 ft bls. These results indicated all three intervals in the zone 4 test were hydraulically isolated. Head separation observed in the zone 4 test indicated a downward vertical gradient above $233 \mathrm{ft}$ bls and an upward vertical gradient below $256.5 \mathrm{ft}$ bls and, subsequently, showed the potential for water from above and below to flow to, and exit, the borehole in the interval 233-256.5 ft bls. 

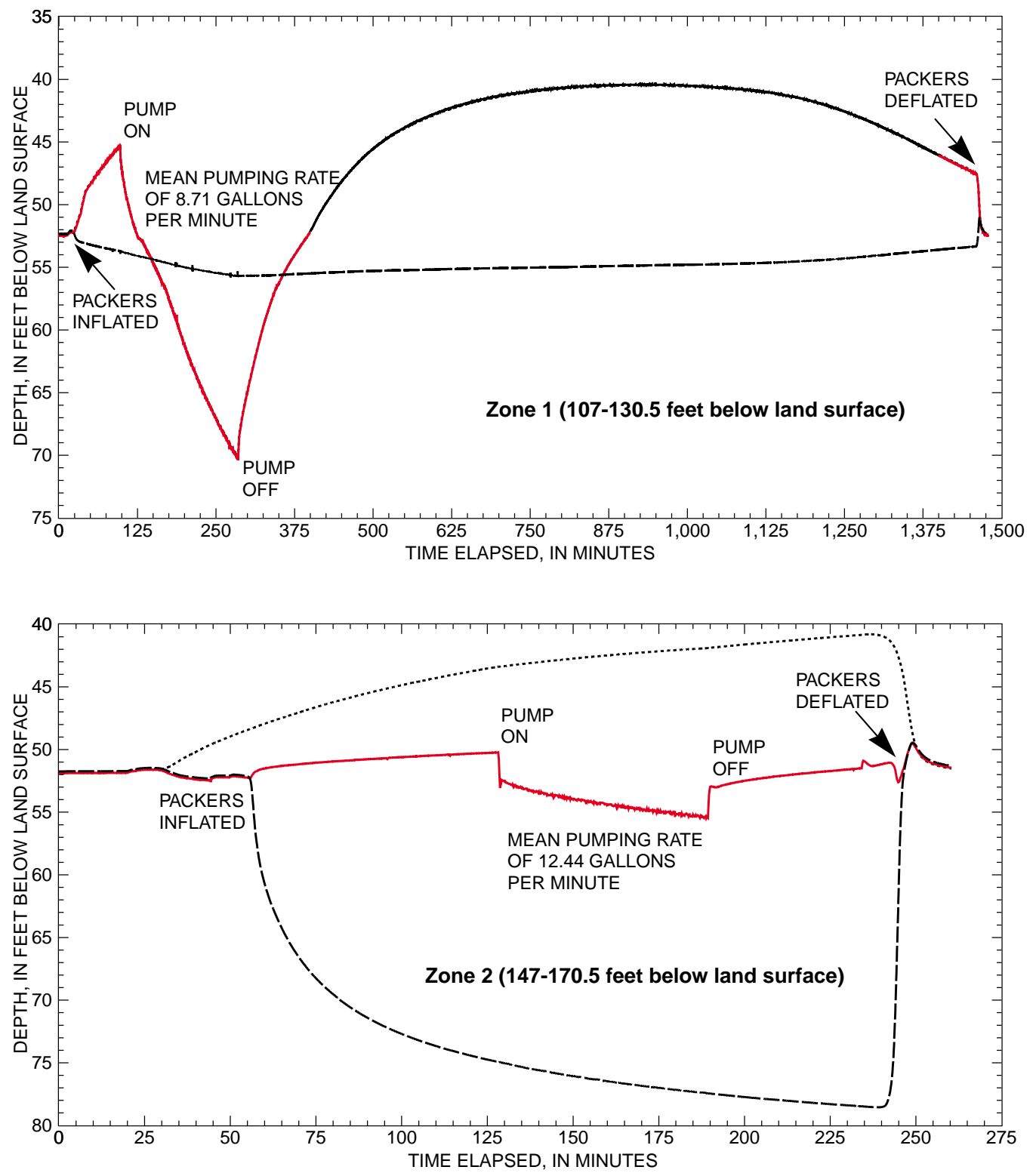

EXPLANATION

WATER LEVEL ABOVE THE ISOLATED INTERVAL

WATER LEVEL IN THE ISOLATED INTERVAL

WATER LEVEL BELOW THE ISOLATED INTERVAL

Figure 43. Depth to water above isolated interval, in isolated interval, and below isolated interval before, during, and after pumping for tests of isolated intervals zone 1 (between 107 and 130.5 feet below land surface) and zone 2 (between 147 and 170.5 feet below land surface) in well MG-202 (L-22), North Penn Area 7 Superfund site, Upper Gwynedd Township, Montgomery County, Pa., December 19-20, 2002. 

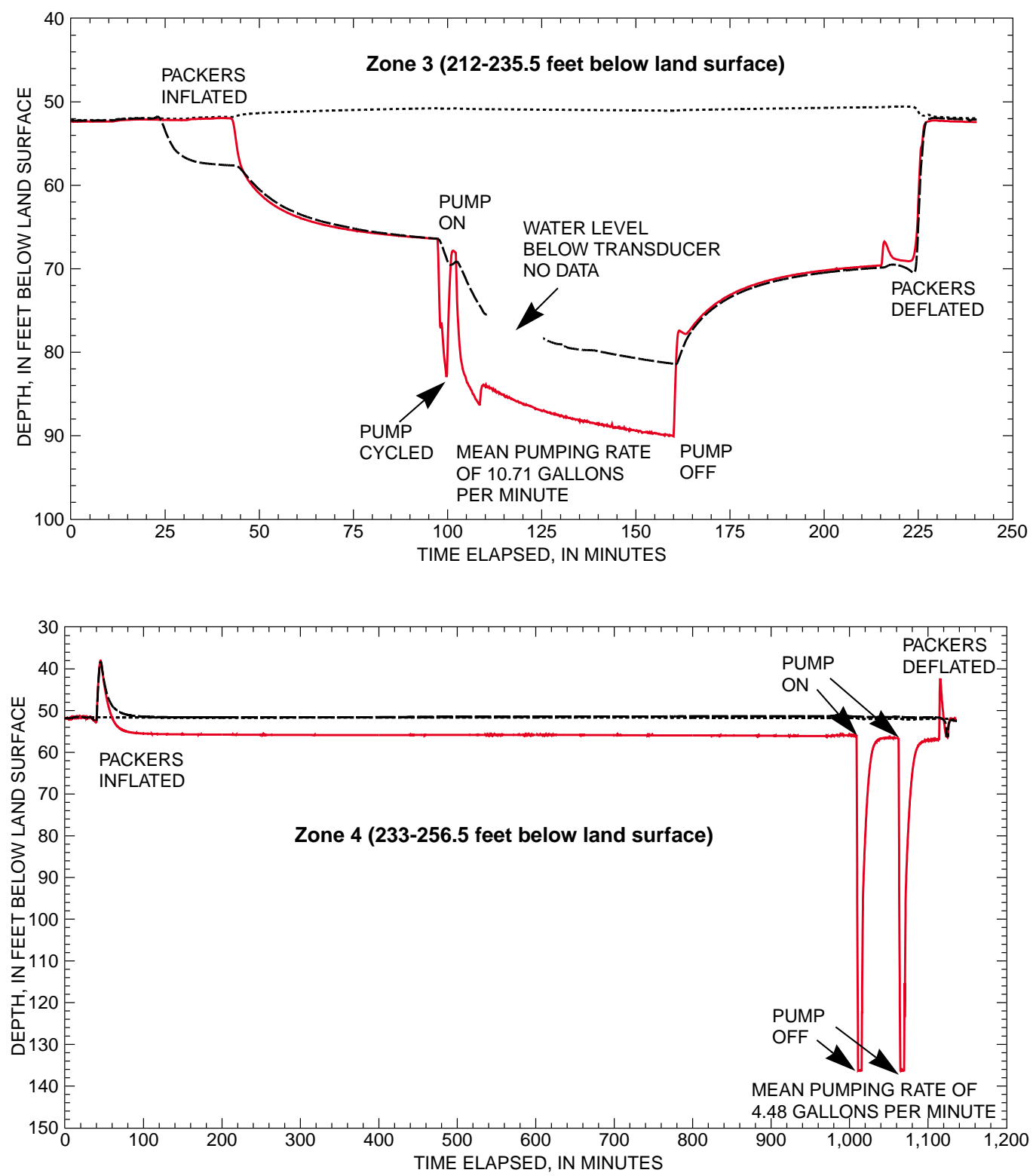

EXPLANATION

WATER LEVEL ABOVE THE ISOLATED INTERVAL

WATER LEVEL IN THE ISOLATED INTERVAL

WATER LEVEL BELOW THE ISOLATED INTERVAL

Figure 44. Depth to water above isolated interval, in isolated interval, and below isolated interval before, during, and after pumping for tests of isolated intervals zone 3 (between 212 and 235.5 feet below land surface) and zone 4 (between 233 and 256.5 feet below land surface) in well MG-202 (L-22), North Penn Area 7 Superfund site, Upper Gwynedd Township, Montgomery County, Pa., December 19-20, 2002. 
Results of the isolation tests indicate that there are at least five hydraulically isolated zones within the well: above $130.5 \mathrm{ft}$ bls (zone 1 test); 147-170.5 ft bls (zone 2 test); 212$235.5 \mathrm{ft}$ bls (zone 3 and 4 tests); 233-256.5 ft bls (zone 4 test); and below $256.5 \mathrm{ft}$ bls (zone 4 test). Data from the isolation tests, in conjunction with data from geophysical logging, indicated that water produced from the intervals above $130.5 \mathrm{ft}$ bls travels downward and exits the borehole within the interval of 147-170.5 ft bls. Lesser amounts of water probably pass downward, past the 147-170.5 ft bls interval, to exit the borehole within the less permeable interval of $212-235.5 \mathrm{ft}$ bls. These findings are indicated by the vertical gradients observed within zones 2 and 4. The minor amount of water produced below $256.5 \mathrm{ft}$ bls travels upwards and exits the borehole within the interval of 233-256.5 ft bls. These determinations are in agreement with the results obtained from geophysical logging. Estimated transmissivity and specific-capacity values determined during isolation tests were greater than those obtained during geophysical logging, in part because of biased results from tests for zones 3 and 4 (table 33); in addition, changes in pumping stress originating from a nearby production well, or wells, may have contributed to the apparent difference in specificcapacity values.

Table 33. Depths, water levels, and specific capacity of aquifer intervals isolated by packers for well MG- 202 (L-22), North Penn Area 7, Upper Gwynedd Township, Montgomery County, Pa.

[ft bls, feet below land surface; ft, feet; gal/min, gallons per minute; min, minutes; (gal/min)/ft, gallons per minute per foot; $\mathrm{ft}^{2} / \mathrm{d}$, feet squared per day; --, no data]

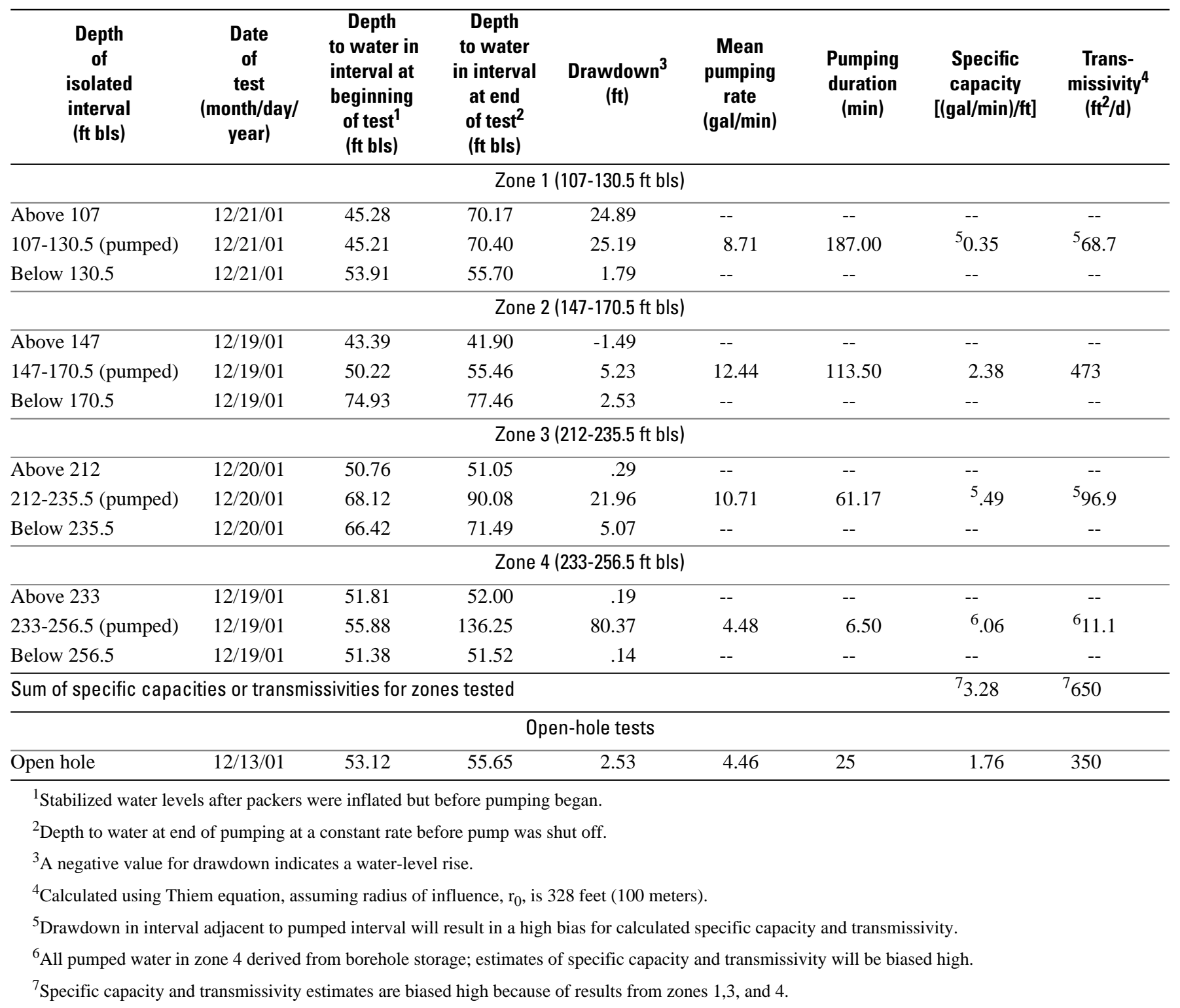


Physical and chemical properties of water pumped from isolated intervals and measured near the end of pumping are listed in table 34. The $\mathrm{pH}$, dissolved-oxygen concentration, temperature, and specific conductance of water from the isolated intervals in well MG-202 (L-22) were varied. Water from zone 2 (water-producing zone) had the lowest dissolved-oxygen concentration $(0.5 \mathrm{mg} / \mathrm{L})$ and the highest temperature, alkalinity, and specific conductance $\left(12^{\circ} \mathrm{C}, 179 \mathrm{mg} / \mathrm{L}\right.$ as $\mathrm{CaCO}_{3}$, and $559 \mu \mathrm{S} / \mathrm{cm}$, respectively). Water from zone 4 (water-receiving zone) had the lowest $\mathrm{pH}$, temperature, alkalinity, and specific conductance (7.00 standard units, $10.5^{\circ} \mathrm{C}$,
$125 \mathrm{mg} / \mathrm{L}$ as $\mathrm{CaCO}_{3}$, and $450 \mu \mathrm{S} / \mathrm{cm}$, respectively) and the highest dissolved-oxygen concentration $(1.3 \mathrm{mg} / \mathrm{L})$. Results of laboratory analysis (table 35) showed concentrations of VOCs differ in water samples collected from isolated intervals. More compounds and higher concentrations of VOCs were detected in intervals below $147 \mathrm{ft}$ bls than in the intervals above that depth (fig. 45). The pumped interval within zone 2 (147$170 \mathrm{ft}$ bls) had the highest overall concentrations. The compounds measured in the highest concentrations were $c i s-1,2-$ DCE and TCE.

Table 34. Inorganic water-quality constituents and physical properties for samples collected from isolated intervals in well MG-202 (L-22), North Penn Area 7, Upper Gwynedd Township, Montgomery County, Pa.

[ft bls, feet below land surface; $\mathrm{mg} / \mathrm{L}$, milligrams per liter; --, no data; ${ }^{\circ} \mathrm{C}$, degrees Celsius, $\mu \mathrm{S} / \mathrm{cm}$ at $25{ }^{\circ} \mathrm{C}$, microsiemens per centimeter at 25 degrees Celsius; $\mathrm{Fe}^{2+}$, ferrous iron; $\mathrm{Fe}$, iron]

\begin{tabular}{|c|c|c|c|c|c|c|c|c|c|c|c|c|}
\hline Zone & $\begin{array}{c}\text { Depth } \\
\text { of } \\
\text { isolated } \\
\text { interval } \\
\text { (ft bls) }\end{array}$ & $\begin{array}{c}\text { Date } \\
\text { sampled } \\
\text { (month/ } \\
\text { day/year) }\end{array}$ & Time & $\begin{array}{c}\text { pH } \\
\text { (standard } \\
\text { units) }\end{array}$ & $\begin{array}{c}\text { Dis- } \\
\text { solved } \\
\text { oxygen } \\
\text { (mg/L) }\end{array}$ & $\begin{array}{c}\text { Temper- } \\
\text { ature } \\
\left({ }^{\circ} \mathrm{C}\right)\end{array}$ & $\begin{array}{c}\text { Specific } \\
\text { conduct- } \\
\text { ance } \\
(\mu \mathrm{S} / \mathrm{cm} \\
\left.\text { at } 25^{\circ} \mathrm{C}\right)\end{array}$ & $\begin{array}{c}\text { Alkalinity } \\
\text { (mg/L) }\end{array}$ & $\begin{array}{l}\text { Sulfide } \\
\text { (mg/L) }\end{array}$ & $\begin{array}{l}\text { Sulfate } \\
\text { (mg/L) }\end{array}$ & $\begin{array}{c}\mathrm{Fe}^{2+} \\
(\mathrm{mg} / \mathrm{L})\end{array}$ & $\begin{array}{c}\text { Fe, } \\
\text { total } \\
(\mathrm{mg} / \mathrm{L})\end{array}$ \\
\hline 1 & $107-130.5$ & $12 / 20 / 01$ & 1350 & 7.67 & -- & 11.7 & 463 & 120.5 & 0.001 & 30 & 0.03 & 0.15 \\
\hline 2 & $147-170.5$ & $12 / 19 / 01$ & 1238 & 7.69 & 0.5 & 12 & 559 & 179.3 & -- & -- & -- & -- \\
\hline 3 & $212-235.5$ & $12 / 20 / 01$ & 1436 & 7.37 & 1.0 & 11.5 & 471 & 131.7 & .012 & 35 & .06 & .16 \\
\hline 4 & $233-256.5$ & $12 / 19 / 01$ & 0954 & 7.00 & 1.3 & 10.5 & 450 & 125 & .003 & 30 & .11 & 1.62 \\
\hline
\end{tabular}

Table 35. Selected volatile organic compound concentrations in water samples from isolated intervals in well MG-202 (L-22), North Penn Area 7 Superfund site, Upper Gwynedd Township, Montgomery County, Pa. (Laboratory results provided by CDM Federal Programs Corporation.)

[ft bls, feet below land surface; $\mu \mathrm{g} / \mathrm{L}$, micrograms per liter; ND, not detected; $\mathrm{L}$, compound present-reported value may be biased low; $>$, greater than]

\begin{tabular}{|c|c|c|c|c|c|c|c|}
\hline Zone & $\begin{array}{c}\text { Depth } \\
\text { of } \\
\text { isolated } \\
\text { interval } \\
\text { (ft bls) }\end{array}$ & $\begin{array}{c}\text { Date } \\
\text { sampled } \\
\text { (month/day/ } \\
\text { year) }\end{array}$ & $\begin{array}{c}\text { Trichloro- } \\
\text { ethylene } \\
(\mu \mathrm{g} / \mathrm{L})\end{array}$ & $\begin{array}{c}\text { cis-1,2- } \\
\text { Dichloro- } \\
\text { ethylene } \\
(\mu \mathrm{g} / \mathrm{L})\end{array}$ & $\begin{array}{c}\text { 1,1- } \\
\text { Dichloro- } \\
\text { ethylene } \\
(\mu \mathrm{g} / \mathrm{L})\end{array}$ & $\begin{array}{c}\text { Toluene } \\
\text { ( } \mu \mathrm{g} / \mathrm{L})\end{array}$ & $\begin{array}{c}\text { trans-1,2- } \\
\text { Dichloro- } \\
\text { ethylene } \\
(\mu \mathrm{g} / \mathrm{L})\end{array}$ \\
\hline 1 & $107-130.5$ & $12 / 20 / 01$ & 2. & 4. & ND & 4.6 & ND \\
\hline 1 duplicate & $107-130.5$ & $12 / 20 / 01$ & 2.2 & 4.3 & ND & 4.7 & ND \\
\hline 2 & $147-170.5$ & $12 / 19 / 01$ & $>60 \mathrm{~L}$ & $>97 \mathrm{~L}$ & $1.0 \mathrm{~L}$ & $2.0 \mathrm{~L}$ & $1.7 \mathrm{~L}$ \\
\hline 3 & $212-235.5$ & $12 / 20 / 01$ & $>34 \mathrm{~L}$ & $>53 \mathrm{~L}$ & $.55 \mathrm{~L}$ & $3.7 \mathrm{~L}$ & $1.1 \mathrm{~L}$ \\
\hline 4 & $233-256.5$ & $12 / 19 / 01$ & $>23 \mathrm{~L}$ & $>36 \mathrm{~L}$ & ND & $23 \mathrm{~L}$ & $.54 \mathrm{~L}$ \\
\hline
\end{tabular}




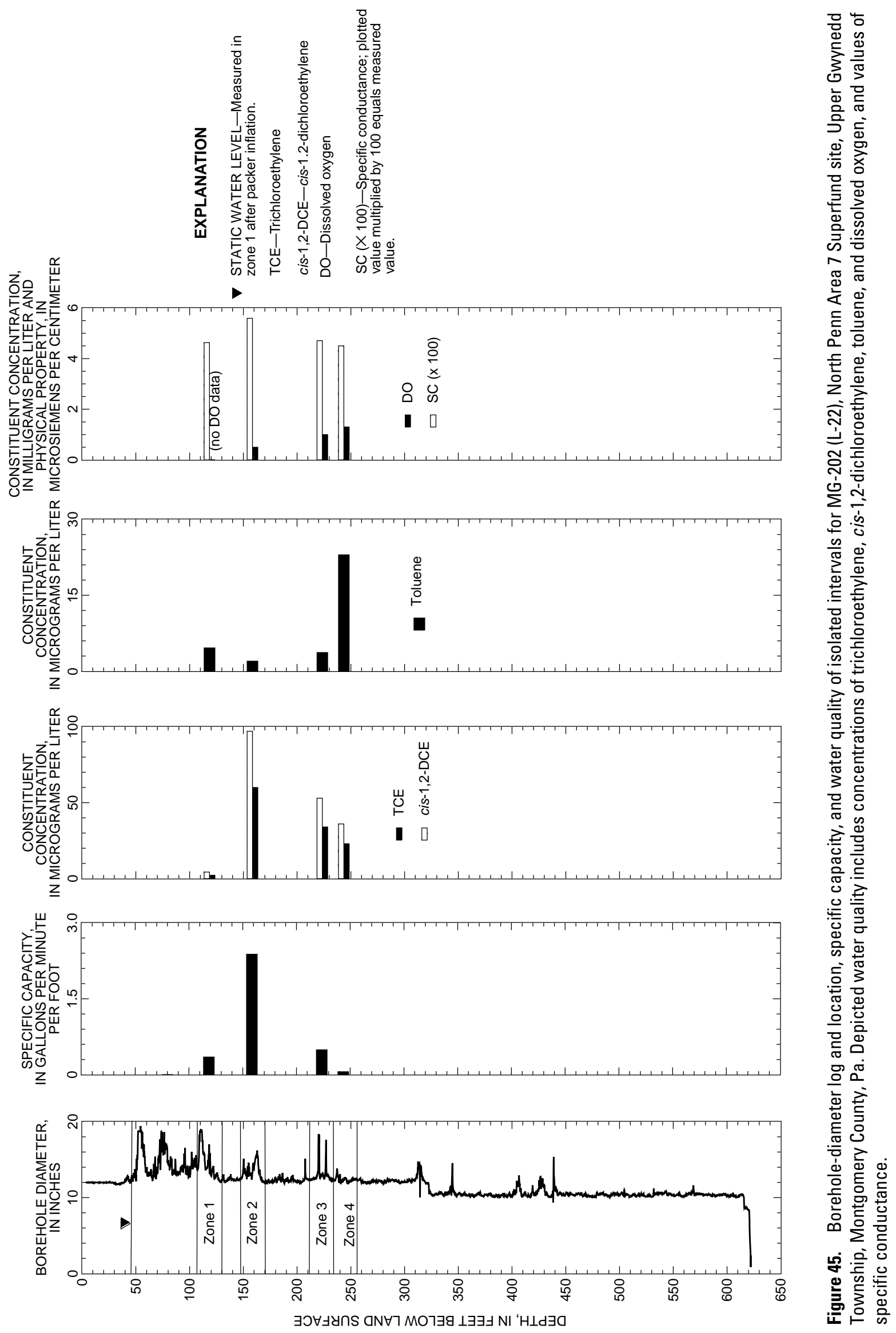




\section{Well MG-1144 (Teleflex T-13)}

Geophysical logging of well MG-1144 indicated probable water-bearing zones in the intervals 33-40, 40-54, 54-64, 65-71, 72-76, and 78-84 ft bls. The water-bearing zones correspond to fractures detected in these intervals on the caliper log (fig. 11). When the well was pumped for heatpulse-flowmeter measurements, the intervals between 64 and 72 and 78 and $84 \mathrm{ft}$ bls were the most productive. Four intervals (zones 1-4, table 36) were selected for isolation based on the results of geophysical logging. The spacing between the mid-points of the straddle packers was $8.5 \mathrm{ft}$ for zone 2 and 3 , and a singlepacker configuration was used for tests of zones 1 and 4 .

Table 36. Isolated intervals tested in well MG-1144 (T-13), North Penn Area 7 Superfund site, Upper Gwynedd Township, Montgomery County, Pa., November 2001.

[ft bls, feet below land surface]

\begin{tabular}{ccc}
\hline Zone & $\begin{array}{c}\text { Depth } \\
\text { of } \\
\text { isolated } \\
\text { interval } \\
\text { (ft bls) }\end{array}$ & $\begin{array}{c}\text { Date } \\
\text { of } \\
\text { test } \\
\text { (month/day/year) }\end{array}$ \\
\hline 1 & Above 56 & $11 / 30 / 01$ \\
2 & $56-64.5$ & $11 / 30 / 01$ \\
3 & $64-72.5$ & $11 / 29 / 01$ \\
4 & Below 72 & $11 / 28 / 01$ \\
\hline
\end{tabular}

The test of zone 1 (above $56 \mathrm{ft}$ bls) indicated the interval above $56 \mathrm{ft}$ bls was hydraulically isolated from the interval below $56 \mathrm{ft}$ bls (fig. 46). Slight head separation upon packer inflation, at $56 \mathrm{ft}$ bls, indicated a downward vertical gradient and, subsequently, potential for downward flow from this zone. The test of zone 2 (56-64.5 ft bls) indicated the interval between 56 and $64.5 \mathrm{ft}$ bls was hydraulically isolated from the intervals above and below (fig. 46). Very slight head separation was noted upon inflation of the upper and lower packers, indicating a very slight downward vertical gradient through this zone.

The test of zone 3 (64-72.5 ft bls) indicated the interval between 64 and $72.5 \mathrm{ft}$ bls had low hydraulic connection to the intervals above and below as noted by the small water-level response in adjacent, nonpumping intervals to pumping in zone 3 (fig. 47). Head separation upon inflation of the upper and lower packers indicated a downward vertical gradient from the upper interval and upward vertical gradient from the lower interval and, subsequently, the potential for water to flow to the isolated interval (zone 3 ) from above and below. The test of zone 4 (below $72 \mathrm{ft}$ bls) indicated the interval below $72 \mathrm{ft}$ bls had low hydraulic connection to the interval above as noted by the small water-level response in the nonpumping interval above zone 4 to pumping in zone 4 (fig. 47). Head separation upon inflation of the packer at $72 \mathrm{ft}$ bls indicated upward vertical gradient and, subsequently, upward flow through this zone. These findings are in agreement with borehole-flow directions determined during geophysical logging.

Results of the isolation tests indicate at least four major hydraulically isolated intervals in the well: above $56 \mathrm{ft}$ bls (zone 1 test), 56-64.5 ft bls (zone 2 test), 64-72.5 ft bls (zone 3 test), and below $72 \mathrm{ft}$ bls (zone 4 test). The interval below $72 \mathrm{ft}$ bls has higher specific capacity than the other intervals (fig. 48; table 37), in agreement with the results obtained from geophysical logging. Where head separation occurred in the tests, a downward vertical gradient was apparent in the intervals above $64 \mathrm{ft}$ bls and an upward vertical gradient was apparent in the intervals below $72 \mathrm{ft}$ bls. These gradients are consistent with flow directions determined during geophysical logging (downward flow was measured in the upper intervals and upward flow was measured in the lower intervals under nonpumping conditions).

Physical and chemical properties of water pumped from isolated intervals and measured near the end of pumping are listed in table 38 . The $\mathrm{pH}$, dissolved-oxygen concentration, temperature, and specific conductance of water from the isolated intervals in well MG-1144 were similar, although water temperatures were cooler $\left(0.5-0.8^{\circ} \mathrm{C}\right)$ in the deeper intervals and water from zone 2 had the lowest $\mathrm{pH}$ and specific conductance (fig. 48; table 38). In general, $\mathrm{pH}$ was near neutral (ranging from 7.13 to 7.54 standard units) and dissolved-oxygen concentrations were relatively higher (ranging from 2.4 to $2.8 \mathrm{mg} / \mathrm{L}$ ) than dissolved-oxygen concentrations in water from most other wells within this study. Field analysis of the inorganic water-quality constituents alkalinity, sulfide, sulfate, ferrous iron, and total iron indicated slightly higher levels of sulfide and iron within zone 3 (table 38). Results of laboratory analysis (table 38) indicate concentrations of VOCs differ in water samples collected from the isolated intervals. TCE, toluene, and cis-1,2-DCE were the compounds measured in the highest concentrations. Compared to water from other zones, water from zone 1 (above $56 \mathrm{ft}$ bls) had the highest concentrations of TCE and cis-1,2-DCE and water from zone 3 (64$72.5 \mathrm{ft}$ bls) had the highest concentration of toluene. 

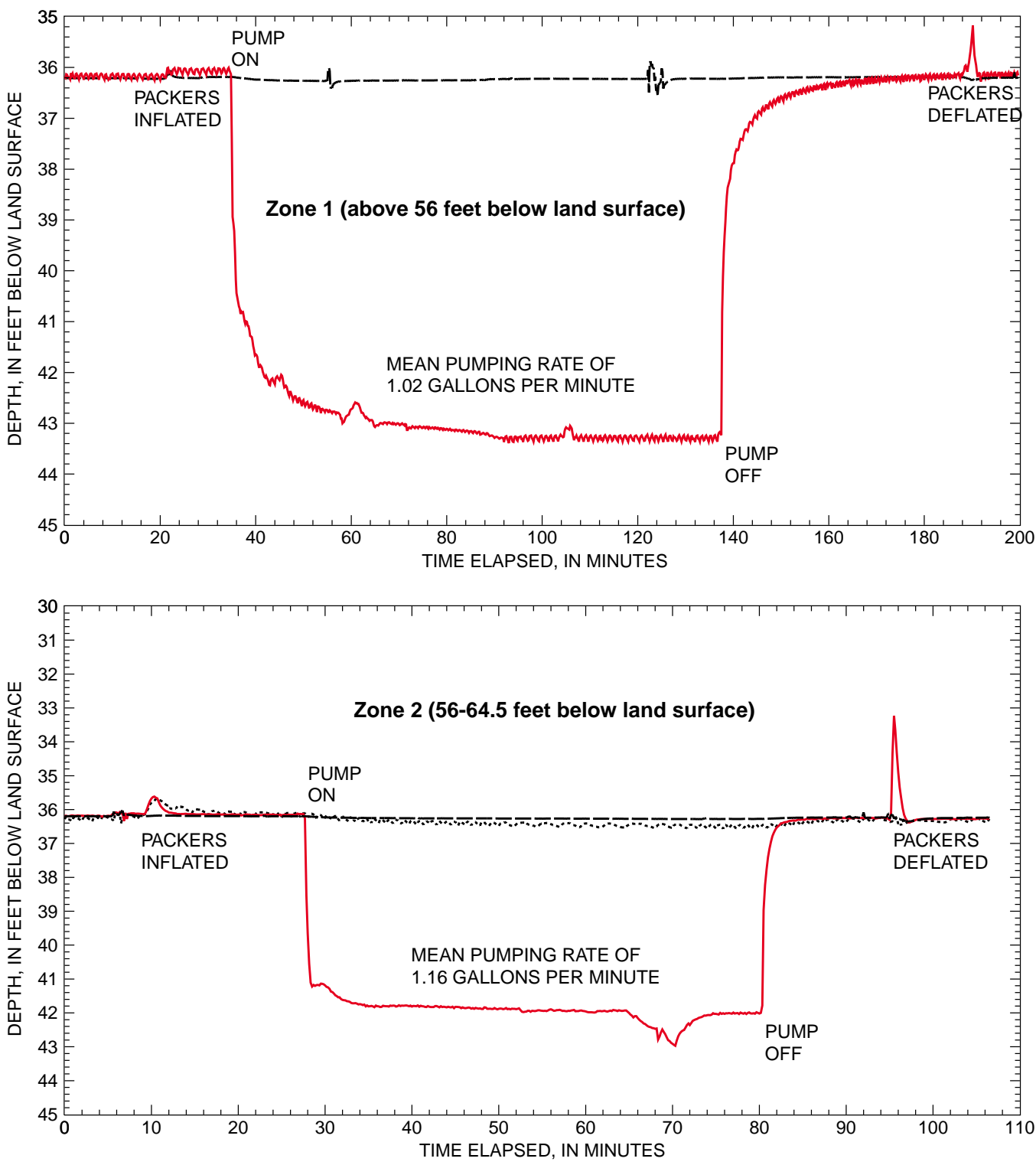

\section{EXPLANATION}

WATER LEVEL ABOVE THE ISOLATED INTERVAL

WATER LEVEL IN THE ISOLATED INTERVAL

WATER LEVEL BELOW THE ISOLATED INTERVAL

Figure 46. Depth to water above isolated interval, in isolated interval, and below isolated interval before, during, and after pumping for tests of isolated intervals zone 1 (above 56 feet below land surface) and zone 2 (between 56 and 64.5 feet below land surface) in well MG-1144 (T-13), North Penn Area 7 Superfund site, Upper Gwynedd Township, Montgomery County, Pa., November 30, 2001. 

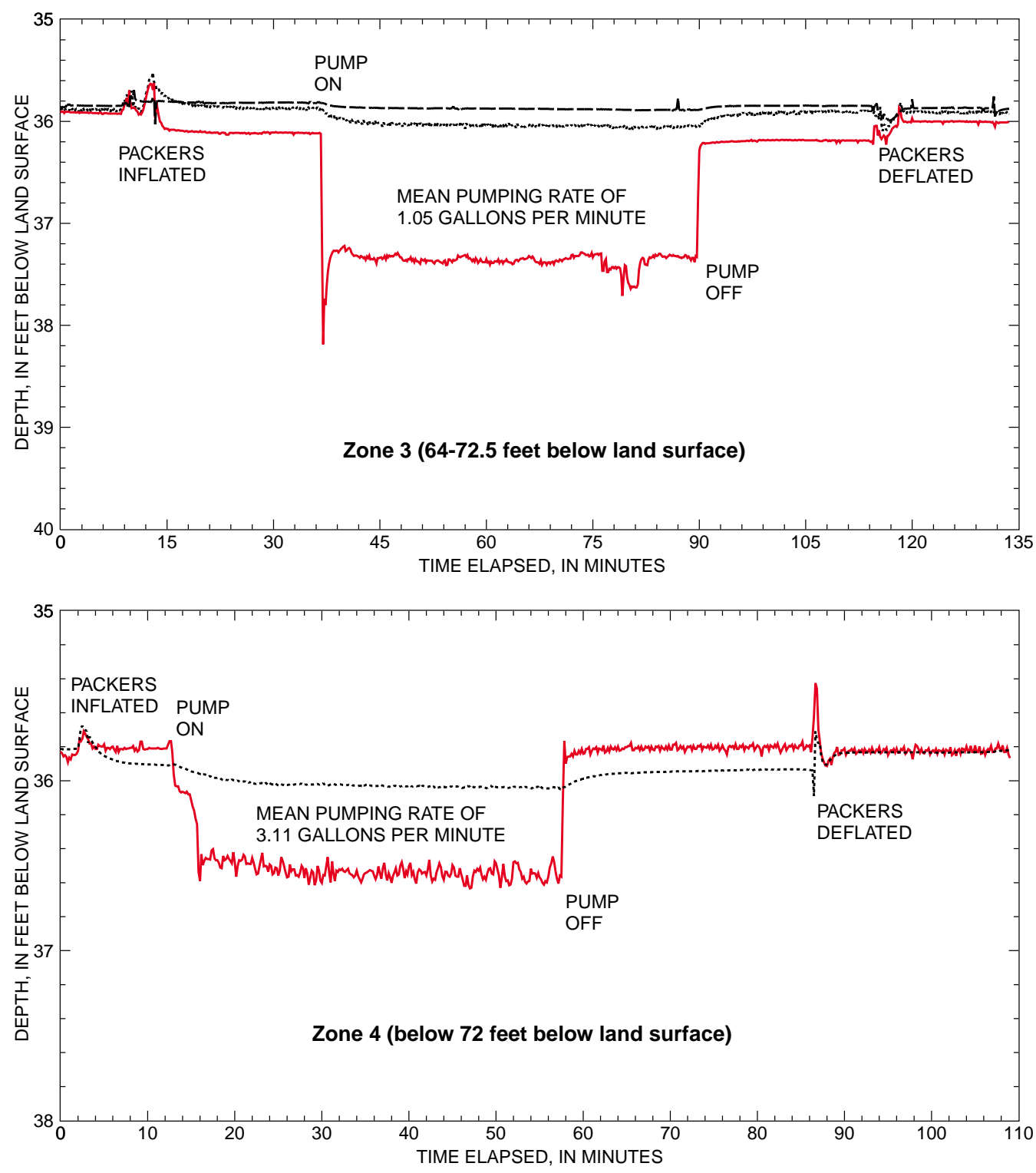

\section{EXPLANATION}

WATER LEVEL ABOVE THE ISOLATED INTERVAL

WATER LEVEL IN THE ISOLATED INTERVAL

WATER LEVEL BELOW THE ISOLATED INTERVAL

Figure 47. Depth to water above isolated interval, in isolated interval, and below isolated interval before, during, and after pumping for tests of isolated intervals zone 3 (between 64 and 72.5 feet below land surface) and zone 4 (below 72 feet below land surface) in well MG-1144 (T-13), North Penn Area 7 Superfund site, Upper Gwynedd Township, Montgomery County, Pa., November 28-29, 2001. 
Table 37. Depths, water levels, and specific capacity of aquifer intervals isolated by packers for well MG-1144 (T-13), North Penn Area 7 Superfund site, Upper Gwynedd Township, Montgomery County, Pa.

[ft bls, feet below land surface; ft, feet; gal/min, gallons per minute; min, minutes; (gal/min)/ft, gallons per minute per foot; $\mathrm{ft}^{2} / \mathrm{d}$, feet squared per day; --, no data]

\begin{tabular}{|c|c|c|c|c|c|c|c|c|}
\hline $\begin{array}{c}\text { Depth } \\
\text { of } \\
\text { isolated } \\
\text { interval } \\
\text { (ft bls) }\end{array}$ & $\begin{array}{l}\text { Date } \\
\text { of } \\
\text { test }\end{array}$ & $\begin{array}{c}\text { Depth } \\
\text { to water in } \\
\text { interval at } \\
\text { beginning } \\
\text { of test }{ }^{1} \\
\text { (ft bls) }\end{array}$ & $\begin{array}{c}\text { Depth } \\
\text { to water in } \\
\text { interval } \\
\text { at end } \\
\text { of test }^{2} \\
\text { (ft bls) }\end{array}$ & $\begin{array}{c}\text { Drawdown } \\
\text { (ft) }\end{array}$ & $\begin{array}{c}\text { Mean } \\
\text { pumping } \\
\text { rate } \\
\text { (gal/min) }\end{array}$ & $\begin{array}{l}\text { Pumping } \\
\text { duration } \\
\text { (min) }\end{array}$ & $\begin{array}{c}\text { Specific } \\
\text { capacity } \\
{[(\text { gal/min } / / f t]}\end{array}$ & $\begin{array}{c}\text { Trans- } \\
\text { missivity } \\
\left.\text { (ft }{ }^{2} / \mathrm{d}\right)\end{array}$ \\
\hline \multicolumn{9}{|c|}{ Zone 1 (above $56 \mathrm{ft}$ bls) } \\
\hline Above 56 (pumped) & $11 / 30 / 01$ & 36.09 & 43.20 & 7.11 & 1.02 & 102.67 & 0.14 & 31.6 \\
\hline Below 56 & $11 / 30 / 01$ & 36.19 & 36.22 & .03 & -- & -- & -- & \\
\hline \multicolumn{9}{|c|}{ Zone 2 (56-64.5 ft bls) } \\
\hline Above 56 & $11 / 30 / 01$ & 36.11 & 36.45 & .34 & -- & -- & -- & \\
\hline 56-64.5 (pumped) & $11 / 30 / 01$ & 36.14 & 41.78 & 5.64 & 1.16 & 52.83 & .21 & 45.3 \\
\hline Below 64 & $11 / 30 / 01$ & 36.20 & 36.27 & .07 & -- & -- & -- & \\
\hline \multicolumn{9}{|c|}{ Zone 3 (64-72.5 ft bls) } \\
\hline Above 64 & $11 / 29 / 01$ & 35.86 & 36.07 & .21 & -- & -- & -- & \\
\hline 64-72.5 (pumped) & $11 / 29 / 01$ & 36.12 & 37.33 & 1.21 & 1.05 & 53.00 & .87 & 191 \\
\hline Below 72.5 & $11 / 29 / 01$ & 35.82 & 35.89 & .07 & -- & -- & -- & \\
\hline \multicolumn{9}{|c|}{ Zone 4 (below $72 \mathrm{ft}$ bls) } \\
\hline Above 72 & $11 / 29 / 01$ & 35.90 & 36.04 & .14 & -- & -- & -- & \\
\hline Below 72 (pumped) & $11 / 29 / 01$ & 35.75 & 36.60 & .85 & 3.11 & 44.83 & 3.63 & 795 \\
\hline Sum of specific capa & es or trans & sivities for $\mathrm{zC}$ & s tested & & & & 4.85 & 1,063 \\
\hline \multicolumn{9}{|c|}{ Open-hole tests } \\
\hline Open hole & $10 / 12 / 01$ & $33.20 ?$ & 33.27 & .07 & .34 & 27 & 4.86 & 1,069 \\
\hline
\end{tabular}

${ }^{1}$ Stabilized water levels after packers were inflated but before pumping began.

${ }^{2}$ Depth to water at end of pumping at a constant rate before pump was shut off.

${ }^{3}$ Calculated using Thiem equation, assuming radius of influence, $r_{0}$, is 328 feet (100 meters). 

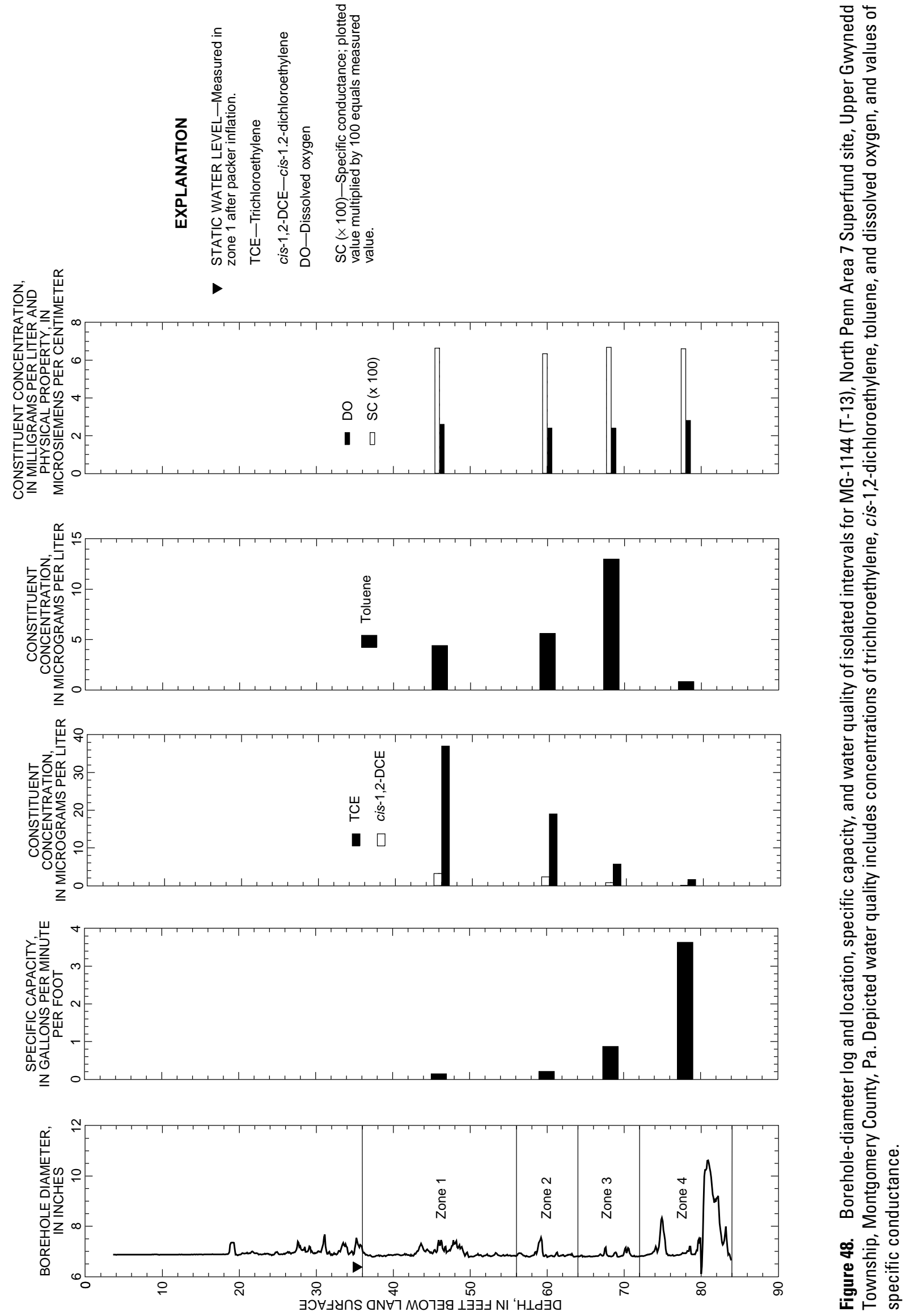
Table 38. Inorganic water-quality constituents and physical properties for samples collected from isolated intervals in well MG-1144 (T-13), North Penn Area 7 Superfund site, Upper Gwynedd Township, Montgomery County, Pa.

[ft bls, feet below land surface; mg/L, milligrams per liter; ${ }^{\circ} \mathrm{C}$, degrees Celsius, $\mu \mathrm{S} / \mathrm{cm}$ at $25^{\circ} \mathrm{C}$, microsiemens per centimeter at 25 degrees $\mathrm{Celsius} ; \mathrm{Fe}^{2+}$, ferrous iron; $\mathrm{Fe}$, iron]

\begin{tabular}{|c|c|c|c|c|c|c|c|c|c|c|c|c|}
\hline Zone & $\begin{array}{l}\text { Depth } \\
\text { of } \\
\text { isolated } \\
\text { interval } \\
\text { (ft bls) }\end{array}$ & $\begin{array}{c}\text { Date } \\
\text { sampled } \\
\text { (month/ } \\
\text { day/year) }\end{array}$ & Time & $\begin{array}{c}\text { pH } \\
\text { (standard } \\
\text { units) }\end{array}$ & $\begin{array}{c}\text { Dis- } \\
\text { solved } \\
\text { oxygen } \\
\text { (mg/L) }\end{array}$ & $\begin{array}{c}\text { Tempera- } \\
\text { ture } \\
\left({ }^{\circ} \mathrm{C}\right)\end{array}$ & $\begin{array}{c}\text { Specific } \\
\text { conduct- } \\
\text { ance } \\
(\mu \mathrm{S} / \mathrm{cm} \\
\left.\text { at } 25^{\circ} \mathrm{C}\right)\end{array}$ & $\begin{array}{c}\text { Alkalinity } \\
\text { (mg/L) }\end{array}$ & $\begin{array}{l}\text { Sulfide } \\
\text { (mg/L) }\end{array}$ & $\begin{array}{l}\text { Sulfate } \\
\text { (mg/L) }\end{array}$ & $\begin{array}{c}\mathrm{Fe}^{2+} \\
(\mathrm{mg} / \mathrm{L})\end{array}$ & $\begin{array}{c}\text { Fe, } \\
\text { total } \\
\text { (mg/L) }\end{array}$ \\
\hline 1 & Above 56 & $11 / 30 / 01$ & 1406 & 7.33 & 2.6 & 14.6 & 664 & 180.3 & 0.001 & 42 & 0.08 & 0.02 \\
\hline 2 & $56-64$ & $11 / 30 / 01$ & 1023 & 7.13 & 2.4 & 14.3 & 635 & 175.2 & .003 & 47 & .1 & .27 \\
\hline 3 & $64-72.6$ & $11 / 29 / 01$ & 1511 & 7.38 & 2.4 & 13.8 & 669 & 186.4 & .012 & 41 & .07 & .35 \\
\hline 4 & Below 72 & $11 / 29 / 01$ & 1135 & 7.54 & 2.8 & 13.5 & 661 & 220.8 & .001 & 39 & .02 & .06 \\
\hline
\end{tabular}

Table 39. Selected volatile organic compound concentrations in water samples from isolated intervals in well MG-1144 (T-13), North Penn Area 7 Superfund site, Upper Gwynedd Township, Montgomery County, Pa. (Laboratory results provided by CDM Federal Programs Corporation.)

[ft bls, feet below land surface; $\mu \mathrm{g} / \mathrm{L}$, micrograms per liter; >, greater than; ND, not detected; J, compound present-reported value may not be accurate or precise]

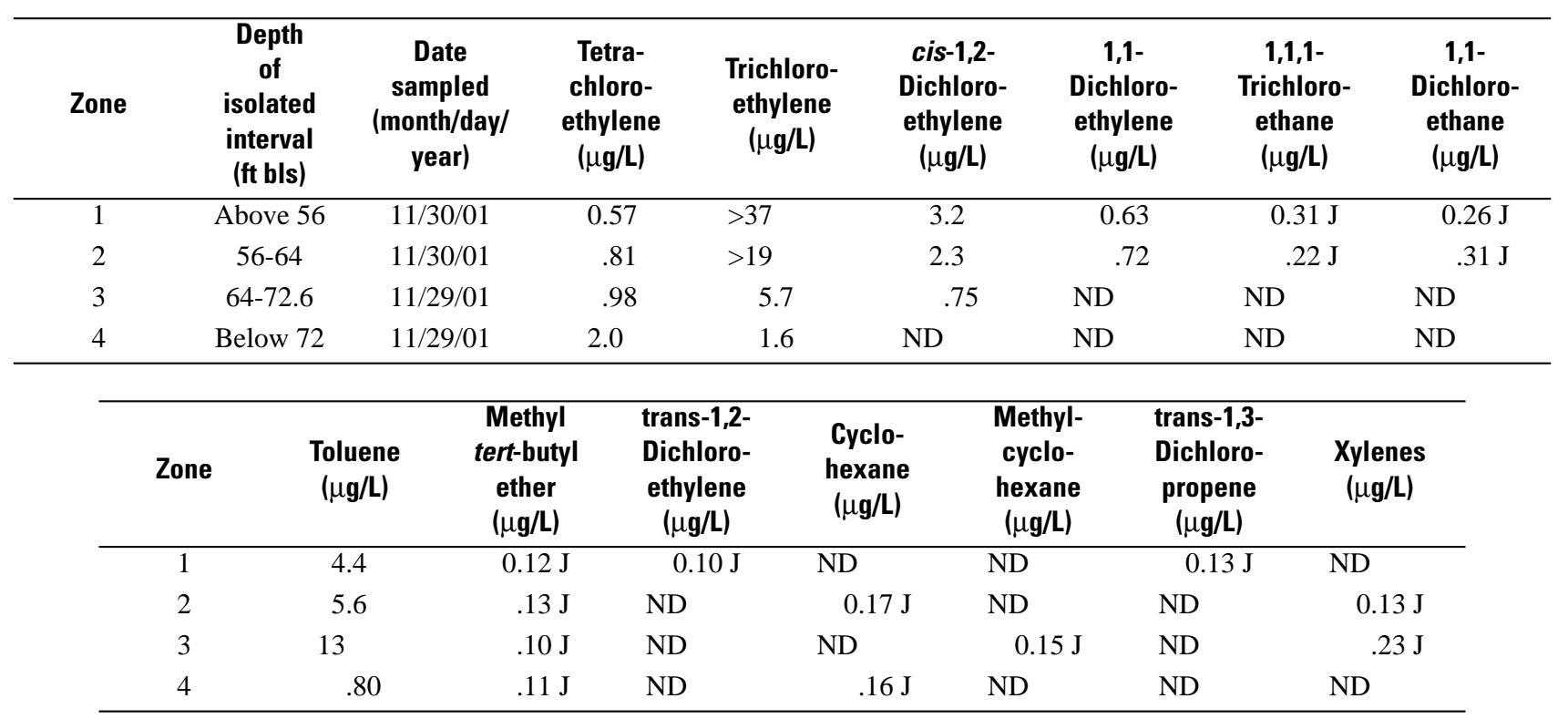




\section{Well MG-1145 (Teleflex T-14)}

Geophysical logging of well MG-1145 indicated probable water-bearing zones in the intervals between 31 and 35, 59 and 68 , and 78 and $83 \mathrm{ft}$ bls. The water-bearing zones correspond to fractures detected in these intervals on the caliper log (fig. 13). When the well was pumped for heatpulse-flowmeter measurements, all intervals produced similar amounts of water. Three intervals were selected for isolation based on results of geophysical logging (zones 1-3, table 40). The spacing between the mid-points of the straddle packers was $16 \mathrm{ft}$ for the test of zone 2, and a single-packer configuration was used for tests of zones 1 and 3 .

Table 40. Isolated intervals tested in well MG-1145 (T-14), North Penn Area 7 Superfund Site, Upper Gwynedd Township, Montgomery County, Pa., December 2001.

[ft bls, feet below land surface]

\begin{tabular}{ccc}
\hline Zone & $\begin{array}{c}\text { Depth } \\
\text { of isolated } \\
\text { interval } \\
\text { (ft bls) }\end{array}$ & $\begin{array}{c}\text { Date } \\
\text { of } \\
\text { test } \\
\text { (month/day/year) }\end{array}$ \\
\hline 1 & Above 47 & $12 / 6 / 01$ \\
2 & $47-63$ & $12 / 5 / 01$ \\
3 & Below 63 & $12 / 5 / 01$ \\
\hline
\end{tabular}

The test of zone 1 (above $46 \mathrm{ft}$ bls) was problematic because the packer was required to be set only $13 \mathrm{ft}$ below the static water level in the well; as a result, there was limited space above the packer assembly for the pump and pressure transducers that record water levels. Pumping the upper interval quickly drew the water level below the depth of the shallow, upper zone pressure transducer making computation of specific capacity using transducer data impossible; however, the test of zone 1 did indicate that the interval above $47 \mathrm{ft}$ bls was not hydraulically connected to intervals below $47 \mathrm{ft}$ bls (fig. 49). Also, the hydraulic head (water level) after packer inflation in the isolated interval above $47 \mathrm{ft}$ bls was slightly higher than the adjacent lower interval, indicating a small downward vertical gradient.

The test of zone 2 (47-63 ft bls) showed the pumped interval between 47 and $63 \mathrm{ft}$ bls was hydraulically isolated from the intervals above and below (fig. 49). Slight responses to pumping stress noted above and below the pumped interval in zone 2 are probably the result of inadequate packer seal. The hydraulic head after packer inflation in the isolated interval 47$63 \mathrm{ft}$ bls was slightly lower than the head adjacent interval above and similar to the head in the interval below, indicating a small downward vertical gradient from above and little to no gradient from below. The test of zone 3 (below $63 \mathrm{ft}$ bls) showed the pumped interval below $63 \mathrm{ft}$ bls was not connected to intervals above $63 \mathrm{ft}$ bls (fig. 50) and had a lower hydraulic head than the combined intervals above.

Results of the isolation tests indicate that there are at least three major hydraulically isolated intervals in the well: above $47 \mathrm{ft}$ bls (zone 1), 47-63 ft bls (zone 2), and below $63 \mathrm{ft} \mathrm{bls}$ (zone 3). All isolated intervals for zones 1, 2, and 3 exhibited head separation (difference in water levels) after packer inflation and (or) very slight, or no, response within adjacent intervals to pumping stress. Where head separation occurred, the water level in the upper interval was higher than the lower interval, indicating a downward vertical gradient consistent with the measurement of downward flow in the borehole under nonpumping conditions at the time of geophysical logging. The producing fractures in zone 1 were estimated by geophysical logging to be in the interval between 31 and $35 \mathrm{ft}$ bls. Because the static water level in the well at the time of the isolation tests was about $34 \mathrm{ft}$ bls, the producing interval between 31 and $35 \mathrm{ft}$ bls was largely de-watered because of drought conditions. Of the two zones ( 2 and 3 ) where specific capacity was computed, specific-capacity values were similar with zone 2 having a slightly higher value (fig 51; table 41). However, given that zone 2 exhibited slight communication between the pumped and adjacent intervals, the specific-capacity value is probably biased slightly high for this zone. Taking into account that zone 1 could not be fully analyzed because of drought conditions, the sum of specific capacities determined from isolation tests might be expected to be less than that determined during the time of geophysical logging (table 41).

Physical and chemical properties of and results of field analysis for inorganic constituents in water pumped from isolated intervals and measured near the end of pumping are listed in table 42 . The $\mathrm{pH}$, dissolved-oxygen concentration, and specific conductance of water from the three isolated intervals in well MG-1145 differed (fig. 51; table 42). The interval above $47 \mathrm{ft}$ bls (zone 1) exhibited the highest dissolved-oxygen concentration and the lowest specific conductance of the three zones. The specific conductance and sulfate concentrations of water from each interval increased with the depth of the zone sampled. Higher concentrations of dissolved and total iron were detected in samples from the interval 47-63 ft bls (zone 2) than in those samples from the intervals above and below 47 $63 \mathrm{ft}$ bls; the higher concentrations of iron in water from zone 2 may be related to the more reducing conditions, indicated by the lower dissolved-oxygen concentration, in water from zone 2 compared to water from the other zones. Results of laboratory analyses (table 43) indicate concentrations of VOCs differ in water samples collected from the isolated intervals. More compounds and higher concentrations of VOCs were detected in samples from the interval above $47 \mathrm{ft}$ bls (zone 1) than intervals below that depth (fig. 51; table 43). Toluene and TCE were the VOC compounds measured in the highest concentrations. 

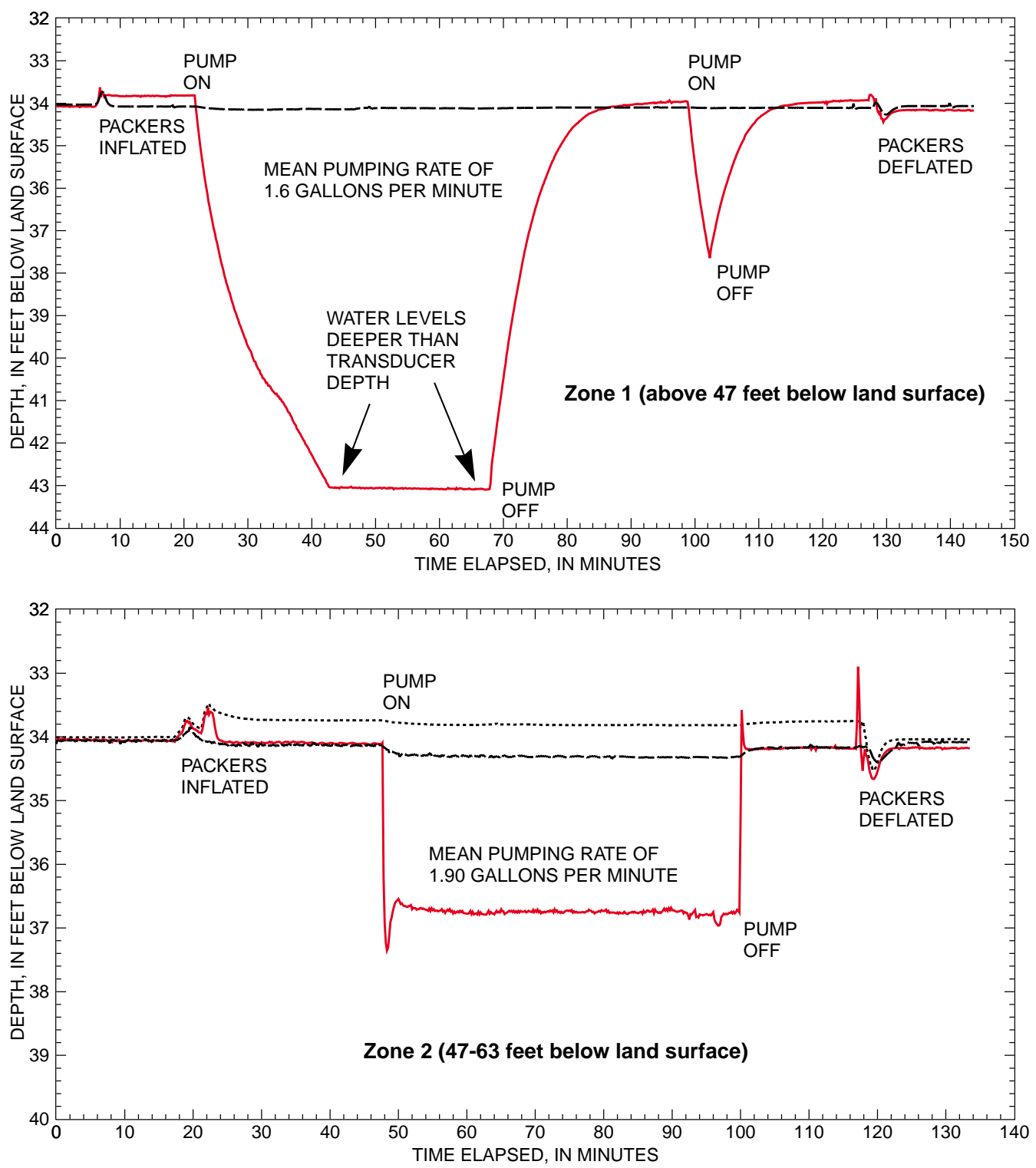

EXPLANATION

WATER LEVEL ABOVE THE ISOLATED INTERVAL WATER LEVEL IN THE ISOLATED INTERVAL WATER LEVEL BELOW THE ISOLATED INTERVAL

Figure 49. Depth to water above isolated interval, in isolated interval, and below isolated interval before, during, and after pumping for tests of isolated intervals zone 1 (above 47 feet below land surface) and zone 2 (between 47 and 63 feet below land surface) in well MG-1145 (T-14), North Penn Area 7 Superfund site, Upper Gwynedd Township, Montgomery County, Pa., December 5-6, 2001. 
Table 41. Depths, water levels, and specific capacity of aquifer intervals isolated by packers for well MG-1145 (T-14), North Penn Area 7, Upper Gwynedd Township, Montgomery County, Pa.

[ft bls, feet below land surface; ft, feet; gal/min, gallons per minute; min, minutes; (gal/min)/ft, gallons per minute per foot; $\mathrm{ft}^{2} / \mathrm{d}$, feet squared per day; >, greater than; <, less than; --, no data]

\begin{tabular}{|c|c|c|c|c|c|c|c|c|}
\hline $\begin{array}{l}\text { Depth } \\
\text { of } \\
\text { isolated } \\
\text { interval } \\
\text { (ft bls) }\end{array}$ & $\begin{array}{c}\text { Date } \\
\text { of } \\
\text { test } \\
\text { (month/day/ } \\
\text { year) }\end{array}$ & $\begin{array}{c}\text { Depth } \\
\text { to water in } \\
\text { interval at } \\
\text { beginning } \\
\text { of test }{ }^{1} \\
\text { (ft bls) }\end{array}$ & $\begin{array}{c}\text { Depth } \\
\text { to water in } \\
\text { interval } \\
\text { at end } \\
\text { of test }{ }^{2} \\
\text { (ft bls) }\end{array}$ & $\begin{array}{c}\text { Drawdown } \\
\text { (ft) }\end{array}$ & $\begin{array}{l}\text { Mean } \\
\text { pumping } \\
\text { rate } \\
\text { (gal/min) }\end{array}$ & $\begin{array}{c}\text { Pumping } \\
\text { duration } \\
\text { (min) }\end{array}$ & $\begin{array}{c}\text { Specific } \\
\text { capacity } \\
{[(\text { gal/min }) / f t]}\end{array}$ & $\begin{array}{c}\text { Trans- } \\
\text { missivity }^{3} \\
\left(\mathrm{ft}^{2} / \mathrm{d}\right)\end{array}$ \\
\hline \multicolumn{9}{|c|}{ Zone 1 (above $47 \mathrm{ft}$ bls) } \\
\hline \multicolumn{9}{|c|}{ Zone 2 (47-63 ft bls) } \\
\hline Above 47 & $12 / 6 / 01$ & 33.74 & 33.82 & .08 & -- & -- & -- & \\
\hline 47-63 (pumped) & $12 / 6 / 01$ & 34.12 & 36.76 & 2.64 & 1.90 & 52.33 & .72 & 158 \\
\hline Below 63 & $12 / 6 / 01$ & 34.09 & 34.28 & .19 & -- & -- & -- & \\
\hline \multicolumn{7}{|c|}{ Sum of specific capacities or transmissivities for zones tested } & ${ }^{6} 1.25$ & 7306 \\
\hline \multicolumn{9}{|c|}{ Open-hole tests } \\
\hline Open hole & $10 / 12 / 01$ & 26.70 & 27.35 & .65 & 1.76 & 36 & 2.71 & 596 \\
\hline \multicolumn{9}{|c|}{${ }^{1}$ Stabilized water levels after packers were inflated but before pumping began. } \\
\hline \multicolumn{9}{|c|}{${ }^{2}$ Depth to water at end of pumping at a constant rate before pump was shut off. } \\
\hline \multicolumn{9}{|c|}{${ }^{3}$ Calculated using Thiem equation, assuming radius of influence, $r_{0}$, is 328 feet (100 meters). } \\
\hline \multicolumn{9}{|c|}{${ }^{4}$ Actual water level is greater than $43.0 \mathrm{ft}$ bls, the last recorded value before the water level dropped below the transducer. } \\
\hline \multicolumn{9}{|c|}{${ }^{5}$ Unable to compute exact values for zone 1 as drawdown exceeded transducer depth. } \\
\hline${ }^{6}$ Does not include zo & e 1 ; the sum of & pecific capacitie & of all zones, in & cluding zone $1, \mathrm{i}$ & ess than 1.39 & $/ \mathrm{min}) / \mathrm{ft}$. & & \\
\hline
\end{tabular}

Table 42. Inorganic water-quality constituents and physical properties for samples collected from isolated intervals in well MG-1145 (T-14), North Penn Area 7 Superfund site, Upper Gwynedd Township, Montgomery County, Pa.

[ft bls, feet below land surface; $\mathrm{mg} / \mathrm{L}$, milligrams per liter; ${ }^{\circ} \mathrm{C}$, degrees Celsius, $\mu \mathrm{S} / \mathrm{cm}$ at $25^{\circ} \mathrm{C}$, microsiemens per centimeter at 25 degrees Celsius; --, no data; $\mathrm{Fe}^{2+}$, ferrous iron; $\mathrm{Fe}$, iron]

\begin{tabular}{|c|c|c|c|c|c|c|c|c|c|c|c|c|}
\hline Zone & $\begin{array}{c}\text { Depth } \\
\text { of } \\
\text { isolated } \\
\text { interval } \\
\text { (ft bls) }\end{array}$ & $\begin{array}{c}\text { Date } \\
\text { sampled } \\
\text { (month/ } \\
\text { day/year) }\end{array}$ & Time & $\begin{array}{c}\text { pH } \\
\text { (standard } \\
\text { units) }\end{array}$ & $\begin{array}{c}\text { Dissolved } \\
\text { oxygen } \\
\text { (mg/L) }\end{array}$ & $\begin{array}{c}\text { Temper- } \\
\text { ature } \\
\left({ }^{\circ} \mathrm{C}\right)\end{array}$ & $\begin{array}{c}\text { Specific } \\
\text { conduct- } \\
\text { ance } \\
(\mu \mathrm{S} / \mathrm{cm} \\
\left.\text { at } 25^{\circ} \mathrm{C}\right)\end{array}$ & $\begin{array}{c}\text { Alkalinity } \\
\text { (mg/L) }\end{array}$ & $\begin{array}{l}\text { Sulfide } \\
\text { (mg/L) }\end{array}$ & $\begin{array}{l}\text { Sulfate } \\
\text { (mg/L) }\end{array}$ & $\begin{array}{c}\mathrm{Fe}^{2+} \\
(\mathrm{mg} / \mathrm{L})\end{array}$ & $\begin{array}{c}\text { Fe, } \\
\text { total } \\
\text { (mg/L) }\end{array}$ \\
\hline 1 & Above 47 & $12 / 6 / 01$ & 1506 & 6.8 & 2.0 & 12.6 & 412 & -- & 0.007 & 32 & 0.04 & 0.14 \\
\hline 2 & $47-63$ & $12 / 6 / 01$ & 1030 & 6.77 & .8 & 12.4 & 580 & 142.8 & .002 & 36 & .19 & .21 \\
\hline 3 & Below 63 & $12 / 5 / 01$ & 1320 & 7.05 & 1.2 & 12.5 & 604 & 152 & .004 & 38 & .05 & .14 \\
\hline
\end{tabular}




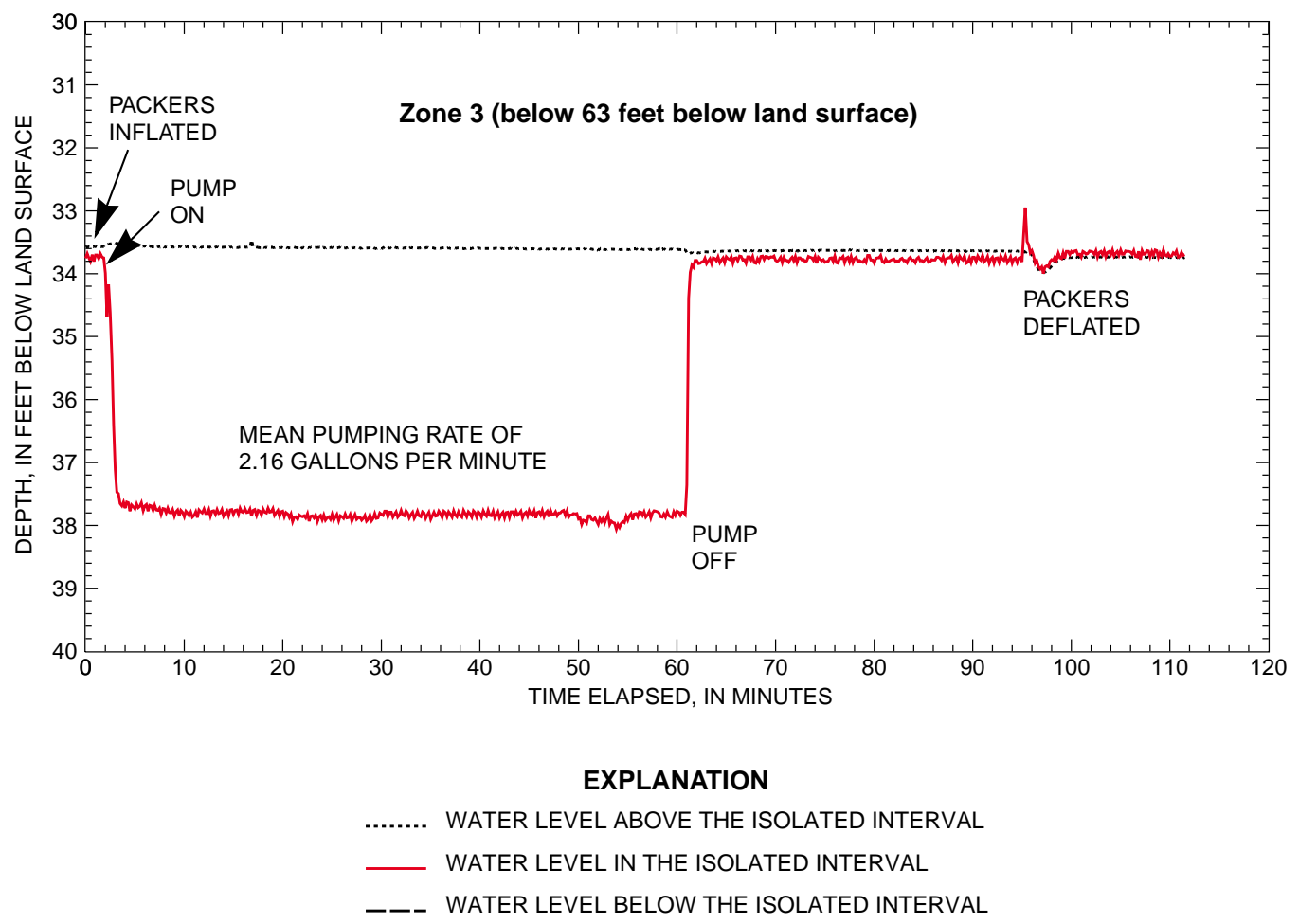

Figure 50. Depth to water above isolated interval, in isolated interval, and below isolated interval before, during, and after pumping for test of isolated interval zone 3 (below 63 feet below land surface) in well MG-1145 (T-14), North Penn Area 7 Superfund site, Upper Gwynedd Township, Montgomery County, Pa., December 5, 2001.

Table 43. Selected volatile organic compound concentrations in water samples from isolated intervals in well MG-1145 (T-14), North Penn Area 7 Superfund site, Upper Gwynedd Township, Montgomery County, Pa. (Laboratory results provided by CDM Federal Programs Corporation.)

[ft bls, feet below land surface; $\mu \mathrm{g} / \mathrm{L}$, micrograms per liter; ND, not detected; J, compound present—reported value may not be accurate or precise]

\begin{tabular}{cccccccc}
\hline Zone & $\begin{array}{c}\text { Depth } \\
\text { of } \\
\text { isolated } \\
\text { interval } \\
(\mathbf{f t} \text { bls) }\end{array}$ & $\begin{array}{c}\text { Date } \\
\text { sampled } \\
\text { (month/day/ } \\
\text { year) }\end{array}$ & $\begin{array}{c}\text { Tetra- } \\
\text { chloro- } \\
\text { ethylene } \\
(\mu \mathbf{g} / \mathrm{L})\end{array}$ & $\begin{array}{c}\text { Trichloro- } \\
\text { ethylene } \\
(\mu \mathrm{g} / \mathrm{L})\end{array}$ & $\begin{array}{c}\text { cis-1,2- } \\
\text { Dichloro- } \\
\text { ethylene } \\
(\mu \mathrm{g} / \mathrm{L})\end{array}$ & $\begin{array}{c}\text { Toluene } \\
(\mu \mathrm{g} / \mathrm{L})\end{array}$ & $\begin{array}{c}\text { Methyl- } \\
\text { tert- } \\
\text { butyl- } \\
\text { ether } \\
(\mu \mathbf{g} / \mathrm{L})\end{array}$ \\
\hline 1 & Above 47 & $12 / 6 / 01$ & $0.24 \mathrm{~J}$ & 1.4 & $0.18 \mathrm{~J}$ & 12 & $0.12 \mathrm{~J}$ \\
2 & $47-63$ & $12 / 6 / 01$ & .97 & 1.3 & $.14 \mathrm{~J}$ & 2.1 & ND \\
3 & Below 63 & $12 / 5 / 01$ & .82 & .93 & $\mathrm{ND}$ & 1.5 & ND \\
\hline
\end{tabular}




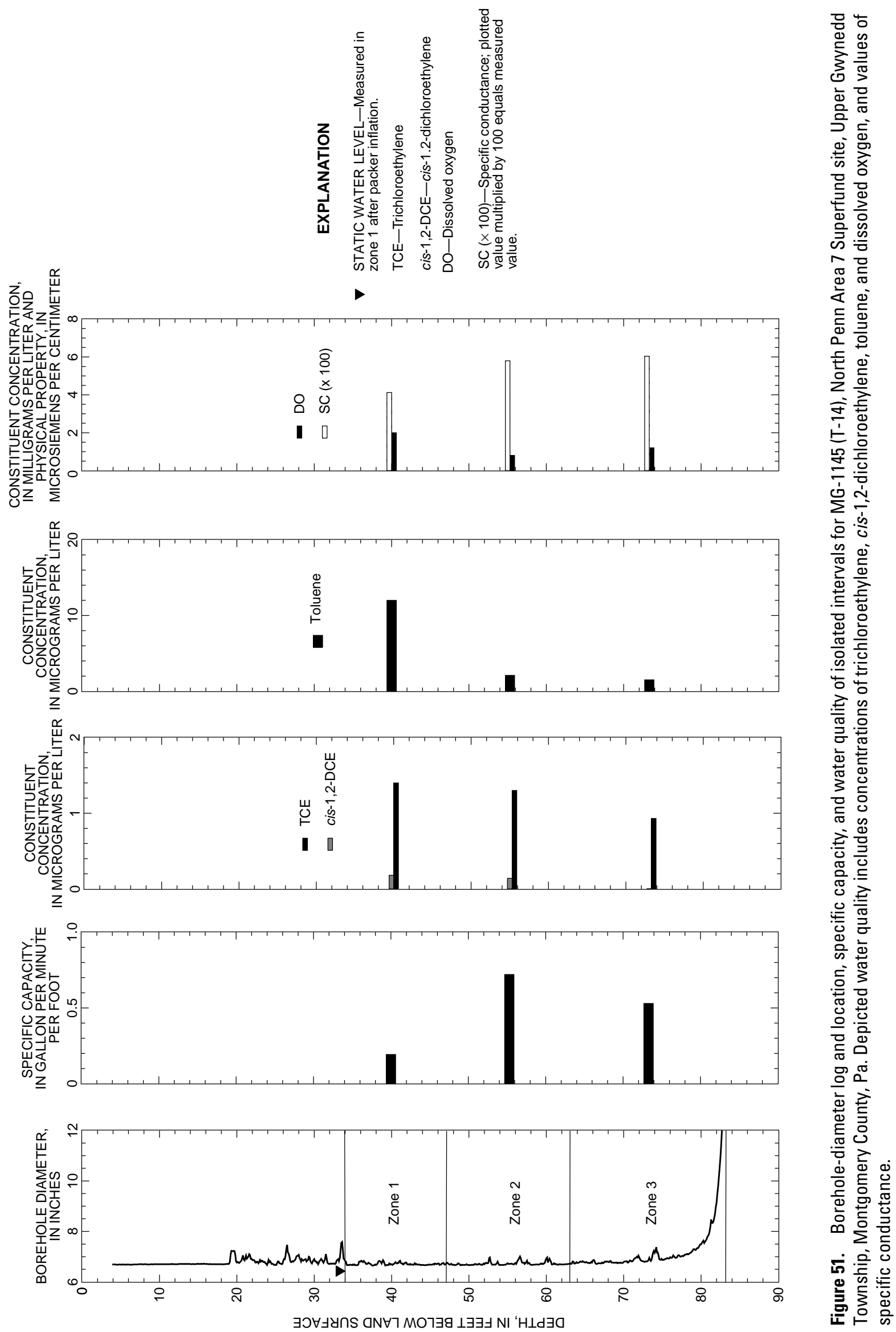




\section{Well MG-1146 (Teleflex T-4)}

Geophysical logging of well MG-1146 indicated probable water-bearing zones in the intervals between 55 and 66 and 76 and $84.5 \mathrm{ft}$ bls. The water-bearing zones correspond to fractures detected in these intervals on the caliper log (fig. 15). When the well was pumped for heatpulse-flow measurements, the interval between 55 and $66 \mathrm{ft}$ bls was apparently the most productive; however, turbulence within the borehole at this depth may have affected flow measurements. Two intervals (zones 1-2, table 44) were selected for isolation based on results of geophysical logging and direct observation of the borehole by borehole video survey. Tests of the two zones in this well used only one packer to isolate the intervals above and below $64 \mathrm{ft}$ bls.

Table 44. Isolated intervals tested in well MG-1146 (T-4), North Penn Area 7 Superfund site, Upper Gwynedd Township, Montgomery County, Pa., November 2001.

[ft bls, feet below land surface]

\begin{tabular}{ccc}
\hline Zone & $\begin{array}{c}\text { Depth } \\
\text { of } \\
\text { isolated } \\
\text { interval } \\
\text { (ft bls) }\end{array}$ & $\begin{array}{c}\text { Date } \\
\text { of } \\
\text { test } \\
\text { (month/day/year) }\end{array}$ \\
\hline 1 & Above 64 & $11 / 27 / 01$ \\
2 & Below 64 & $11 / 28 / 01$ \\
\hline
\end{tabular}

The tests of zone 1 (above $64 \mathrm{ft}$ bls) and zone 2 (below $64 \mathrm{ft}$ bls) indicated the interval above $64 \mathrm{ft}$ bls had a slight to moderate hydraulic connection to the interval below (fig. 52). Data from each test, along with data from geophysical logs, generally indicated both intervals probably were hydraulically connected outside of the borehole as a result of aquifer properties. Tests of the intervals in both zones, above $64 \mathrm{ft}$ bls and below $64 \mathrm{ft}$ bls, were characterized by a lack of head separation after packer inflation and a muted response to pumping stress either below or above the pumped interval, as applicable. Little or no head separation (difference in water levels) after packer inflation and (or) a noted response within an adjacent zone to pumping stress may indicate a hydraulic connection between isolated intervals. Hydraulic connection between intervals outside of the borehole commonly leads to the absence, or reduction, of vertical gradient within the borehole, and subsequently, the absence, or reduction, of vertical flow. The finding that no vertical flow was measured in the borehole of MG-1146 under nonpumping conditions at the time of geophysical logging agrees with the lack of head separation observed in the isolation tests.

Results of the isolation tests indicate at least two producing intervals in the well-above and below $64 \mathrm{ft}$ bls. These intervals appeared to be hydraulically connected by fractures or openings in the aquifer outside the borehole, and the specific capacity calculated for each interval was affected by some contribution, indicated by drawdown, from the adjacent interval. However, hydraulic characteristics of each interval differ. The interval above $64 \mathrm{ft}$ bls had a relatively higher specific capacity than the interval below $64 \mathrm{ft}$ bls (fig. 53; table 45). The interval above $64 \mathrm{ft}$ bls (zone 1) was pumped for a much longer period at a higher pumping rate and with less drawdown than the interval below $64 \mathrm{ft}$ bls (zone 2). The lower specific capacity of the interval below $64 \mathrm{ft}$ bls was evident by the rapid dewatering of the interval observed during the test (fig. 52). The relative productivity of the two intervals tested was consistent with heatpulse-flowmeter measurements made during geophysical logging under pumping conditions.

Physical and chemical properties of water pumped from isolated intervals and measured near the end of pumping are listed in table 46. The $\mathrm{pH}$, dissolved-oxygen concentration, temperature, and specific conductance of water from the isolated intervals in well MG-1146 were similar (fig. 53; table 46). In general, the $\mathrm{pH}$ was near neutral in both zones (ranging from 7.35 to $7.46 \mathrm{pH}$ units) and dissolved-oxygen concentrations were generally low (less than $0.5-0.6 \mathrm{mg} / \mathrm{L}$ ). Results of field chemical analysis (table 46) indicate that concentrations of iron and ferrous iron differ between the two intervals and are higher in the interval below $64 \mathrm{ft}$ bls. Higher concentrations of VOCs also were detected in the lower interval (table 47). TCE, cis-1,2-DCE, toluene, 1,1-DCE, and 1,1,2-trichloro-1,2,2-trifluoroethane were the compounds measured in the highest concentrations. 

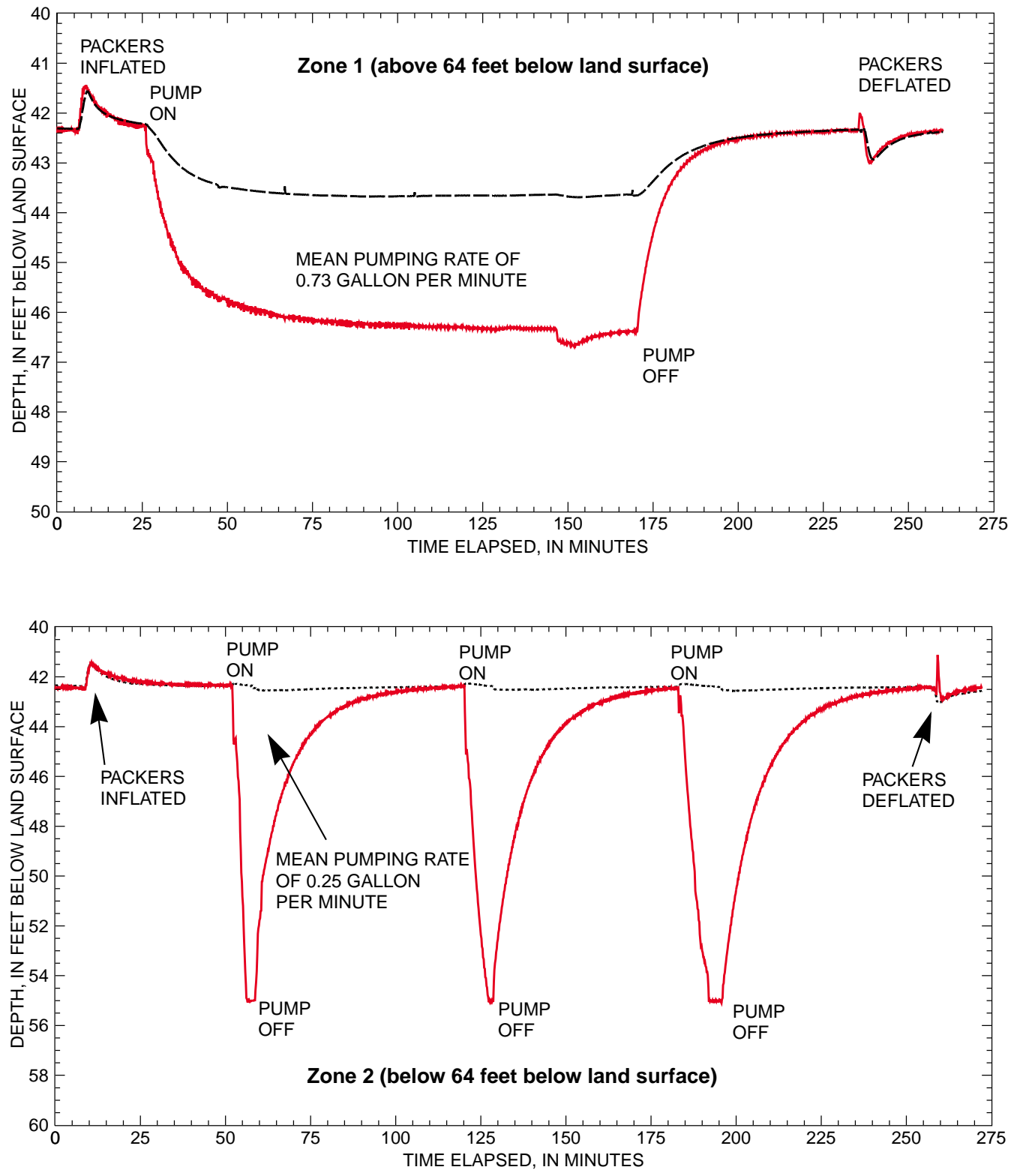

EXPLANATION

WATER LEVEL ABOVE THE ISOLATED INTERVAL WATER LEVEL IN THE ISOLATED INTERVAL WATER LEVEL BELOW THE ISOLATED INTERVAL

Figure 52. Depth to water in isolated interval and in adjacent isolated interval before, during, and after pumping for tests of isolated intervals zone 1 (above 64 feet below land surface) and zone 2 (below 64 feet below land surface) in well MG-1146 (T-4), North Penn Area 7, Upper Gwynedd Township, Montgomery County, Pa., November 27-28, 2001. 

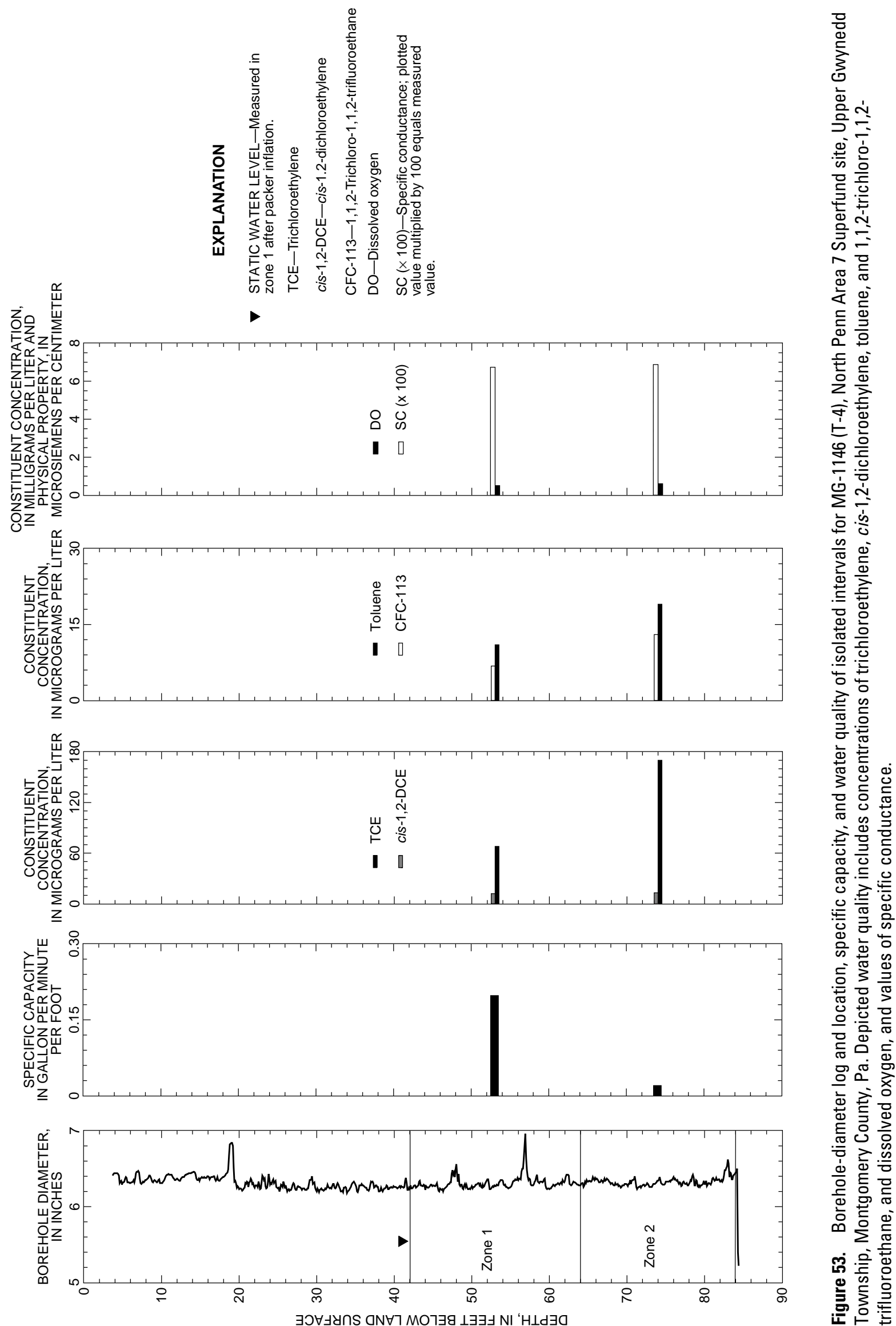
Table 45. Depths, water levels, and specific capacity of aquifer intervals isolated by packers for well MG-1146 (T-4), North Penn Area 7 Superfund site, Upper Gwynedd Township, Montgomery County, Pa.

[ft bls, feet below land surface; ft, feet; gal/min, gallon per minute; min, minutes; (gal/min)/ft, gallons per minute per foot; $\mathrm{ft}^{2} / \mathrm{d}$, feet squared per day; --, no data]

\begin{tabular}{|c|c|c|c|c|c|c|c|c|}
\hline $\begin{array}{l}\text { Depth } \\
\text { of } \\
\text { isolated } \\
\text { interval } \\
\text { (ft bls) }\end{array}$ & $\begin{array}{c}\text { Date } \\
\text { of } \\
\text { test } \\
\text { (month/day/ } \\
\text { year) }\end{array}$ & $\begin{array}{c}\text { Depth } \\
\text { to water in } \\
\text { interval at } \\
\text { beginning } \\
\text { of test }{ }^{1} \\
\text { (ft bls) }\end{array}$ & $\begin{array}{c}\text { Depth } \\
\text { to water in } \\
\text { interval } \\
\text { at end } \\
\text { of test }{ }^{2} \\
\text { (ft bls) }\end{array}$ & $\begin{array}{c}\text { Drawdown } \\
\text { (ft) }\end{array}$ & $\begin{array}{c}\text { Mean } \\
\text { pumping } \\
\text { rate } \\
\text { (gal/min) }\end{array}$ & $\begin{array}{c}\text { Pumping } \\
\text { duration } \\
\text { (min) }\end{array}$ & $\begin{array}{c}\text { Specific } \\
\text { capacity } \\
{[(\text { gal/min)/ft] }}\end{array}$ & $\begin{array}{l}\text { Trans- } \\
\text { missivity }^{3} \\
\left(\mathrm{ft}^{2} / \mathrm{d}\right)\end{array}$ \\
\hline \multicolumn{9}{|c|}{ Zone 1 (above $64 \mathrm{ft}$ bls) } \\
\hline Above 64 (pumped) $^{4}$ & $11 / 28 / 01$ & 42.62 & 46.31 & 3.69 & 0.73 & 144.3 & 0.20 & 43.5 \\
\hline Below 64 & $11 / 28 / 01$ & 42.22 & 43.65 & 1.43 & -- & -- & -- & \\
\hline \multicolumn{9}{|c|}{ Zone 2 (below $64 \mathrm{ft}$ bls) } \\
\hline Above 64 & $11 / 27 / 01$ & 42.39 & 42.53 & .14 & -- & -- & -- & \\
\hline Below 64 (pumped) ${ }^{5}$ & $11 / 27 / 01$ & 42.46 & 54.89 & 12.43 & .25 & 13.0 & ${ }^{5} .02$ & ${ }^{6} 4.4$ \\
\hline \multicolumn{7}{|c|}{ Sum of specific capacities or transmissivities for zones tested } & 6.22 & 647.9 \\
\hline \multicolumn{9}{|c|}{ Open-hole tests } \\
\hline Open hole & $10 / 10 / 01$ & 39.00 & 43.36 & 4.36 & .94 & 35.0 & .22 & 47.5 \\
\hline \multicolumn{9}{|c|}{${ }^{1}$ Stabilized water levels after packers were inflated but before pumping began. } \\
\hline \multicolumn{9}{|c|}{${ }^{2}$ Depth to water at end of pumping at a constant rate before pump was shut off. } \\
\hline \multicolumn{9}{|c|}{${ }^{3}$ Calculated using Thiem equation, assuming radius of influence, $r_{0}$, is 328 feet (100 meters). } \\
\hline \multicolumn{9}{|c|}{${ }^{4}$ Transducer located in drop pipe above pump. } \\
\hline
\end{tabular}

Table 46. Inorganic water-quality constituents and physical properties for samples collected from isolated intervals in well MG-1146 (T-4), North Penn Area 7 Superfund site, Upper Gwynedd Township, Montgomery County, Pa.

[ft bls, feet below land surface; $\mathrm{mg} / \mathrm{L}$, milligrams per liter; <, less than; ${ }^{\circ} \mathrm{C}$, degrees Celsius, $\mu \mathrm{S} / \mathrm{cm}$ at $25{ }^{\circ} \mathrm{C}$, microsiemens per centimeter at 25 degrees Celsius; $\mathrm{Fe}^{2+}$, ferrous iron; Fe, iron]

\begin{tabular}{|c|c|c|c|c|c|c|c|c|c|c|c|c|}
\hline Zone & $\begin{array}{l}\text { Depth } \\
\text { of } \\
\text { isolated } \\
\text { interval } \\
\text { (ft bls) }\end{array}$ & $\begin{array}{c}\text { Date } \\
\text { sampled } \\
\text { (month/ } \\
\text { day/year) }\end{array}$ & Time & $\begin{array}{c}\text { pH } \\
\text { (standard } \\
\text { units) }\end{array}$ & $\begin{array}{c}\text { Dis- } \\
\text { solved } \\
\text { oxygen } \\
\text { (mg/L) }\end{array}$ & $\begin{array}{c}\text { Temper- } \\
\text { ature } \\
\left({ }^{\circ} \mathrm{C}\right)\end{array}$ & $\begin{array}{c}\text { Specific } \\
\text { conduct- } \\
\text { ance } \\
(\mu \mathrm{S} / \mathrm{cm} \\
\left.\text { at } 25^{\circ} \mathrm{C}\right)\end{array}$ & $\begin{array}{c}\text { Alkalinity } \\
\text { (mg/L) }\end{array}$ & $\begin{array}{l}\text { Sulfide } \\
\text { (mg/L) }\end{array}$ & $\begin{array}{l}\text { Sulfate } \\
\text { (mg/L) }\end{array}$ & $\begin{array}{c}\mathrm{Fe}^{2+} \\
(\mathrm{mg} / \mathrm{L})\end{array}$ & $\begin{array}{c}\text { Fe, } \\
\text { total } \\
\text { (mg/L) }\end{array}$ \\
\hline 1 & Above 64 & $11 / 28 / 01$ & 1135 & 7.46 & $<0.5$ & 14.9 & 674 & 194.5 & 0.005 & 44 & 0.07 & 0.2 \\
\hline 2 & Below 64 & $11 / 27 / 01$ & 1419 & 7.35 & .6 & 15.4 & 688 & 192.5 & .009 & 45 & .13 & .76 \\
\hline
\end{tabular}


Table 47. Selected volatile organic compound concentrations in water samples from isolated intervals in well MG-1146 (T-4), North Penn Area 7 Superfund site, Upper Gwynedd Township, Montgomery County, Pa. (Laboratory results provided by CDM Federal Programs Corporation.)

[ft bls, feet below land surface; $\mu \mathrm{g} / \mathrm{L}$, micrograms per liter; >, greater than; J, compound present—reported value may not be accurate or precise; ND, not detected]

\begin{tabular}{|c|c|c|c|c|c|c|c|}
\hline Zone & $\begin{array}{c}\text { Depth } \\
\text { of } \\
\text { isolated } \\
\text { interval } \\
\text { (ft bls) }\end{array}$ & $\begin{array}{c}\text { Date } \\
\text { sampled } \\
\text { (month/day/ } \\
\text { year) }\end{array}$ & $\begin{array}{c}\text { Tetra- } \\
\text { chloro- } \\
\text { ethylene } \\
(\mu \mathrm{g} / \mathrm{L})\end{array}$ & $\begin{array}{c}\text { Trichloro- } \\
\text { ethylene } \\
(\mu \mathrm{g} / \mathrm{L})\end{array}$ & $\begin{array}{c}\text { cis-1,2- } \\
\text { Dichloro- } \\
\text { ethylene } \\
(\mu \mathrm{g} / \mathrm{L})\end{array}$ & $\begin{array}{c}1,1- \\
\text { Dichloro- } \\
\text { ethylene } \\
(\mu \mathrm{g} / \mathrm{L})\end{array}$ & $\begin{array}{c}\text { 1,1,1- } \\
\text { Trichloro- } \\
\text { ethane } \\
\text { ( } \mu \mathrm{g} / \mathrm{L})\end{array}$ \\
\hline 1 & Above 64 & $11 / 28 / 01$ & 1.3 & $>68$ & 12 & 8.8 & 2.5 \\
\hline 2 & Below 64 & $11 / 27 / 01$ & 1.5 & $>170$ & 13 & 8.9 & 3.1 \\
\hline Zone & $\begin{array}{c}\text { 1,1,2- } \\
\text { Trichloro- } \\
\text { ethane } \\
\text { ( } \mu \mathrm{g} / \mathrm{L})\end{array}$ & $\begin{array}{c}\text { 1,1- } \\
\text { Dichloro- } \\
\text { ethan } \\
(\mu \mathrm{g} / \mathrm{L})\end{array}$ & $\begin{array}{c}\text { Toluene } \\
\text { ( } \mu \mathrm{g} / \mathrm{L})\end{array}$ & $\begin{array}{c}\text { 1,1,2- } \\
\text { Trichloro- } \\
\text { 1,2,2- } \\
\text { trifluoro- } \\
\text { ethane } \\
\text { ( } \mu \mathrm{g} / \mathrm{L})\end{array}$ & $\begin{array}{c}\text { Methyl tert- } \\
\text { butyl } \\
\text { ether } \\
(\mu \mathrm{g} / \mathrm{L})\end{array}$ & $\begin{array}{c}\text { trans-1,2- } \\
\text { Dichloro- } \\
\text { ethylene } \\
(\mu \mathrm{g} / \mathrm{L})\end{array}$ & $\begin{array}{c}\text { Cyclohexane } \\
(\mu \mathrm{g} / \mathrm{L})\end{array}$ \\
\hline 1 & $0.13 \mathrm{~J}$ & 2.5 & 11 & 6.8 & ND & $0.31 \mathrm{~J}$ & $0.23 \mathrm{~J}$ \\
\hline 2 & $.17 \mathrm{~J}$ & 3.1 & 19 & 13 & $0.23 \mathrm{~J}$ & $.18 \mathrm{~J}$ & ND \\
\hline
\end{tabular}

\section{Well MG-1147 (Teleflex T-11)}

Geophysical logging of well MG-1147 indicated probable water-bearing zones in the intervals between 62 and 74 and 74 and $83.5 \mathrm{ft}$ bls. The water-bearing zones correspond to fractures detected in these intervals on the caliper log (fig. 17). When the well was pumped for heatpulse-flowmeter measurements, both zones appeared about equally productive. Two intervals (zones 1-2, table 48) were initially selected for isolation based on results of geophysical logging. Tests of the two zones used only one packer to isolate the intervals above $71.5 \mathrm{ft}$ bls and below $72.4 \mathrm{ft}$ bls.

Table 48. Isolated intervals tested in well MG-1147 (T-11), North Penn Area 7 Superfund site, Upper Gwynedd Township, Montgomery County, Pa., November 2001.

[ft bls, feet below land surface]

\begin{tabular}{ccc}
\hline Zone & $\begin{array}{c}\text { Depth } \\
\text { of } \\
\text { isolated } \\
\text { interval } \\
\text { (ft bls) }\end{array}$ & $\begin{array}{c}\text { Date } \\
\text { of } \\
\text { test } \\
\end{array}$ \\
\hline 1 & Above 71.5 & $11 / 16 / 01$ \\
2 & Below 72.4 & $11 / 15 / 01$ \\
\hline
\end{tabular}

The test of zone 1 showed the interval above $71.5 \mathrm{ft}$ bls had a slight hydraulic connection to the interval below $71.5 \mathrm{ft}$ bls (fig. 54). The test of zone 1 was characterized by a lack of head separation after packer inflation and a slight response to pumping stress in the interval below the pumped zone. Little or no head separation (difference in water levels) after packer inflation and (or) a noted response within an adjacent zone to pumping stress commonly indicates a hydraulic connection between isolated intervals. The test of zone 2 , however, showed the interval above $72.4 \mathrm{ft}$ bls had no measurable response to pumping the interval below $72.4 \mathrm{ft}$ bls (fig. 54), suggesting little to no hydraulic connection between the isolated intervals. Given that an adequate seal was obtained $1 \mathrm{ft}$ lower at zone 2 (72.4 ft bls), it is possible the slight apparent hydraulic connection apparent between the two intervals in the test of zone 1 was caused by limited hydraulic connection outside the borehole or by inadequate packer seal inside the borehole at $71.5 \mathrm{ft}$ bls.

The test of zone 2 (below $72.4 \mathrm{ft}$ bls) was characterized by a lack of head separation after packer inflation, although there was no noted response to pumping stress above the pumped interval. The lack of response to pumping stress indicates the packer seal was adequate and the two intervals are not hydraulically connected. Given adequate packer seal, lack of head separation after packer inflation indicates the absence of vertical gradient and, subsequently, the absence of vertical flow within the borehole. The finding that no vertical flow was measured in the borehole of MG-1147 under nonpumping conditions at the time of geophysical logging agrees with the results of the isolation tests.

Results from the isolation tests indicate at least two hydraulically isolated intervals in the well-above $71.5 \mathrm{ft}$ bls (zone 1 test) and below $72.4 \mathrm{ft}$ bls (zone 2 test). The test of zone 2 resulted in rapid dewatering of the pumped interval and, subsequently, no specific capacity could be computed (fig. 55; table 49). On the basis of these data, the upper zone would be expected to produce more water under pumping conditions. 

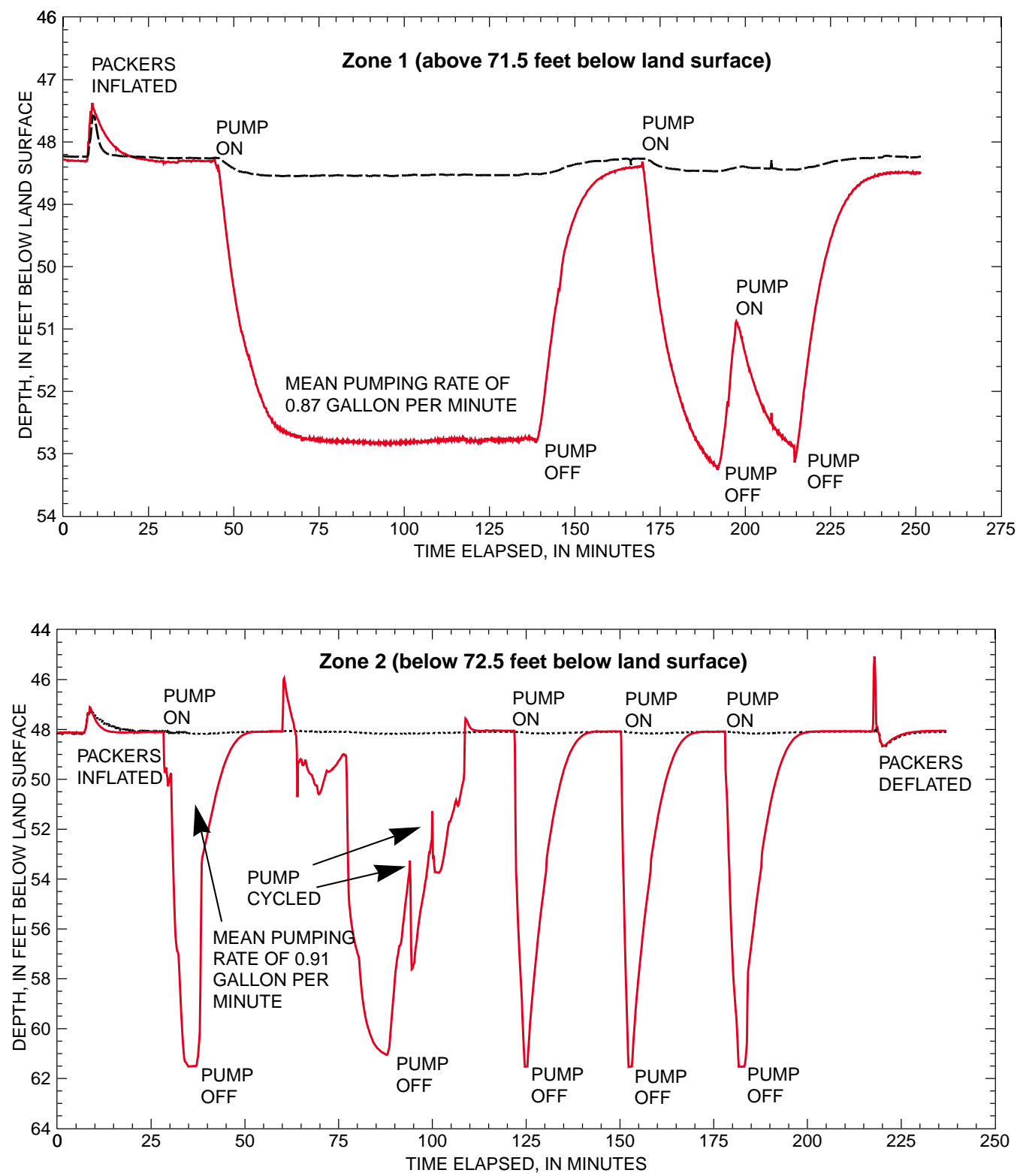

EXPLANATION

WATER LEVEL ABOVE THE ISOLATED INTERVAL

WATER LEVEL IN THE ISOLATED INTERVAL

WATER LEVEL BELOW THE ISOLATED INTERVAL

Figure 54. Depth to water above isolated interval, in isolated interval, and below isolated interval before, during, and after pumping for tests of isolated intervals zone 1 (above 71.5 feet below land surface) and zone 2 (below 72.4 feet below land surface) in well MG-1147 (T-11), North Penn Area 7 Superfund site, Upper Gwynedd Township, Montgomery County, Pa., November 15-16, 2001. 

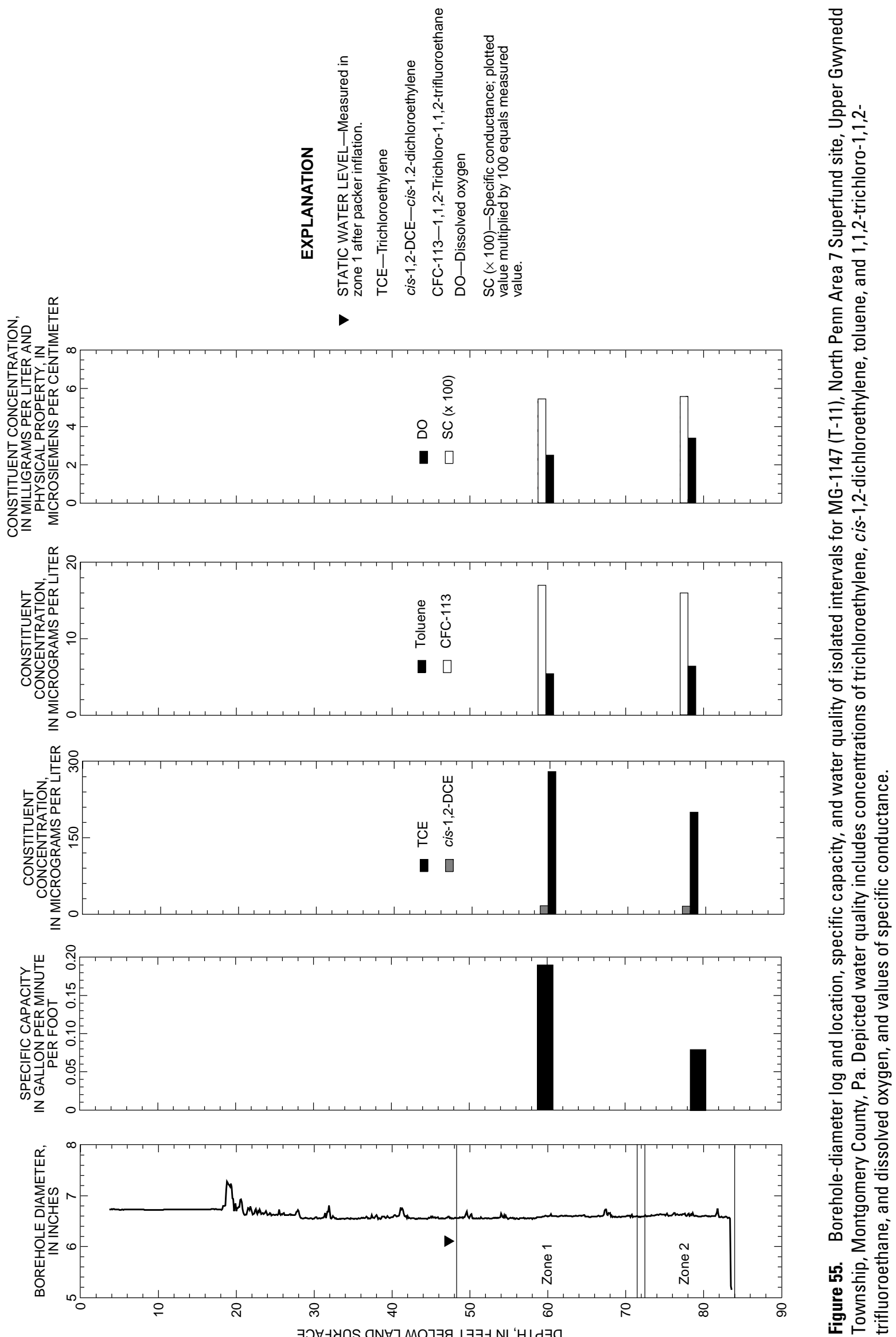
Specific capacities determined from both the isolation tests and geophysical logging substantiate these findings; however, geophysical logging data also provided conflicting evidence, because both intervals produced similar amounts of water under pumping conditions for heatpulse-flowmeter measurements.

Physical and chemical properties of water pumped from isolated intervals and measured near the end of pumping are listed in table 50. The $\mathrm{pH}$, temperature, and specific conductance of water from the isolated intervals in well MG-1147 were similar, but dissolved-oxygen concentration and alkalin- ity were slightly higher in water from the deeper interval (fig. 55; table 50). In general, $\mathrm{pH}$ was near neutral (ranging from 7.58 to $7.62 \mathrm{pH}$ units) and dissolved-oxygen concentrations were moderate to relatively high (ranging from 2.5 to 3.4 $\mathrm{mg} / \mathrm{L}$ ) compared to those properties in water from other wells sampled in this study. Results of laboratory analysis (table 51) indicate concentrations of VOCs generally are similar in water samples collected from the isolated intervals. TCE, cis-1,2DCE, and 1,1,2-trichloro-1,2,2-trifluoroethane were the compounds measured in the highest concentrations.

Table 49. Depths, water levels, and specific capacity of aquifer intervals isolated by packers for well MG-1147 (T-11), North Penn Area 7 Superfund site, Upper Gwynedd Township, Montgomery County, Pa.

[ft bls, feet below land surface; ft, feet; gal/min, gallons per minute; min, minutes; (gal/min)/ft, gallons per minute per foot; $\mathrm{ft}^{2} / \mathrm{d}$, feet squared per day; ,-- no data]

\begin{tabular}{|c|c|c|c|c|c|c|c|c|}
\hline $\begin{array}{l}\text { Depth } \\
\text { of } \\
\text { isolated } \\
\text { interval } \\
\text { (ft bls) }\end{array}$ & $\begin{array}{c}\text { Date } \\
\text { of } \\
\text { test } \\
\text { (month/day/ } \\
\text { year) }\end{array}$ & $\begin{array}{c}\text { Depth } \\
\text { to water in } \\
\text { interval at } \\
\text { beginning } \\
\text { of test } \\
\text { (ft bls) }\end{array}$ & $\begin{array}{c}\text { Depth } \\
\text { to water } \\
\text { in interval } \\
\text { at end } \\
\text { of test }{ }^{2} \\
\text { (ft bls) }\end{array}$ & $\begin{array}{l}\text { Drawdown } \\
\text { (ft) }\end{array}$ & $\begin{array}{c}\text { Mean } \\
\text { pumping rate } \\
\text { (gal/min) }\end{array}$ & $\begin{array}{l}\text { Pumping } \\
\text { duration } \\
\text { (min) }\end{array}$ & $\begin{array}{c}\text { Specific } \\
\text { capacity } \\
{[(\text { gal } / \mathrm{min}) / \mathrm{ft}]}\end{array}$ & $\begin{array}{c}\text { Trans- } \\
\text { missivity }^{3} \\
\left(\mathrm{ft}^{2} / \mathrm{d}\right)\end{array}$ \\
\hline \multicolumn{9}{|c|}{ Zone 1 (above $71.5 \mathrm{ft} \mathrm{bls)}$} \\
\hline Above 71.5 (pumped) $^{4}$ & $11 / 16 / 01$ & 48.19 & 52.80 & 4.61 & 0.87 & 73 & 0.19 & 41.5 \\
\hline Below 71.5 & $11 / 16 / 01$ & 48.23 & 48.54 & .31 & -- & -- & -- & -- \\
\hline \multicolumn{9}{|c|}{ Zone 2 (below $72.5 \mathrm{ft} \mathrm{bls)}{ }^{5}$} \\
\hline Above 72.4 & $11 / 15 / 01$ & 48.11 & 48.13 & .06 & -- & -- & -- & -- \\
\hline Below 72.4 (pumped) $)^{5}$ & $11 / 15 / 01$ & 48.11 & 61.51 & 13.40 & .91 & 6 & ${ }^{6} .07$ & ${ }^{6} 14.9$ \\
\hline \multicolumn{7}{|c|}{ Sum of specific capacities or transmissivities for zones tested } & 6.26 & 656.4 \\
\hline \multicolumn{9}{|c|}{ Open-hole tests } \\
\hline Open hole & $8 / 30 / 01$ & 39.43 & 46.20 & 6.77 & 1.33 & 96 & .20 & 43.2 \\
\hline Open hole & $10 / 10 / 01$ & 43.33 & 47.22 & 3.69 & .98 & 20 & .27 & 58.4 \\
\hline \multicolumn{9}{|c|}{${ }^{1}$ Stabilized water levels after packers were inflated but before pumping began. } \\
\hline \multicolumn{9}{|c|}{${ }^{2}$ Depth to water at end of pumping at a constant rate before pump was shut off. } \\
\hline \multicolumn{9}{|c|}{${ }^{3}$ Calculated using Thiem equation, assuming radius of influence, $r_{0}$, is 328 feet (100 meters). } \\
\hline \multicolumn{9}{|c|}{${ }^{4}$ Transducer located in drop pipe above pump. } \\
\hline \multicolumn{9}{|c|}{${ }^{5}$ Unable to compute values for zone 2 because of low specific capacity of pumped interval. } \\
\hline
\end{tabular}

Table 50. Inorganic water-quality constituents and physical properties for samples collected from isolated intervals in well MG-1147 (T-11), North Penn Area 7 Superfund site, Upper Gwynedd Township, Montgomery County, Pa.

[ft bls, feet below land surface; $\mathrm{mg} / \mathrm{L}$, milligrams per liter; ${ }^{\circ} \mathrm{C}$, degrees Celsius, $\mu \mathrm{S} / \mathrm{cm}$ at $25^{\circ} \mathrm{C}$, microsiemens per centimeter at 25 degrees Celsius]

\begin{tabular}{|c|c|c|c|c|c|c|c|c|}
\hline Zone & $\begin{array}{c}\text { Depth } \\
\text { of } \\
\text { isolated } \\
\text { interval } \\
\text { (ft bls) }\end{array}$ & $\begin{array}{c}\text { Date } \\
\text { sampled } \\
\text { (month/day/ } \\
\text { year) }\end{array}$ & Time & $\begin{array}{c}\text { pH } \\
\text { (standard } \\
\text { units) }\end{array}$ & $\begin{array}{c}\text { Dis- } \\
\text { solved oxygen } \\
\text { (mg/L) }\end{array}$ & $\begin{array}{c}\text { Temper- } \\
\text { ature } \\
\left({ }^{\circ} \mathrm{C}\right)\end{array}$ & $\begin{array}{c}\text { Specific } \\
\text { conductance } \\
(\mu \mathrm{S} / \mathrm{cm} \\
\left.\text { at } 25^{\circ} \mathrm{C}\right)\end{array}$ & $\begin{array}{c}\text { Alkalinity } \\
\text { (mg/L) }\end{array}$ \\
\hline 1 & Above 71.5 & $11 / 16 / 01$ & 1137 & 7.62 & 2.5 & 15.2 & 545 & 152 \\
\hline 2 & Below 72.4 & $11 / 15 / 01$ & 1451 & 7.58 & 3.4 & 15.3 & 558 & 173.2 \\
\hline
\end{tabular}


Table 51. Selected volatile organic compound concentrations in water samples from isolated intervals in well MG-1147 (T-11), North Penn Area 7 Superfund site, Upper Gwynedd Township, Montgomery County, Pa. (Laboratory results provided by CDM Federal Programs Corporation.)

[ft bls, feet below land surface; $\mu \mathrm{g} / \mathrm{L}$, micrograms per liter; >, greater than; J, compound present—reported value may not be accurate or precise; $\mathrm{ND}$, not detected]

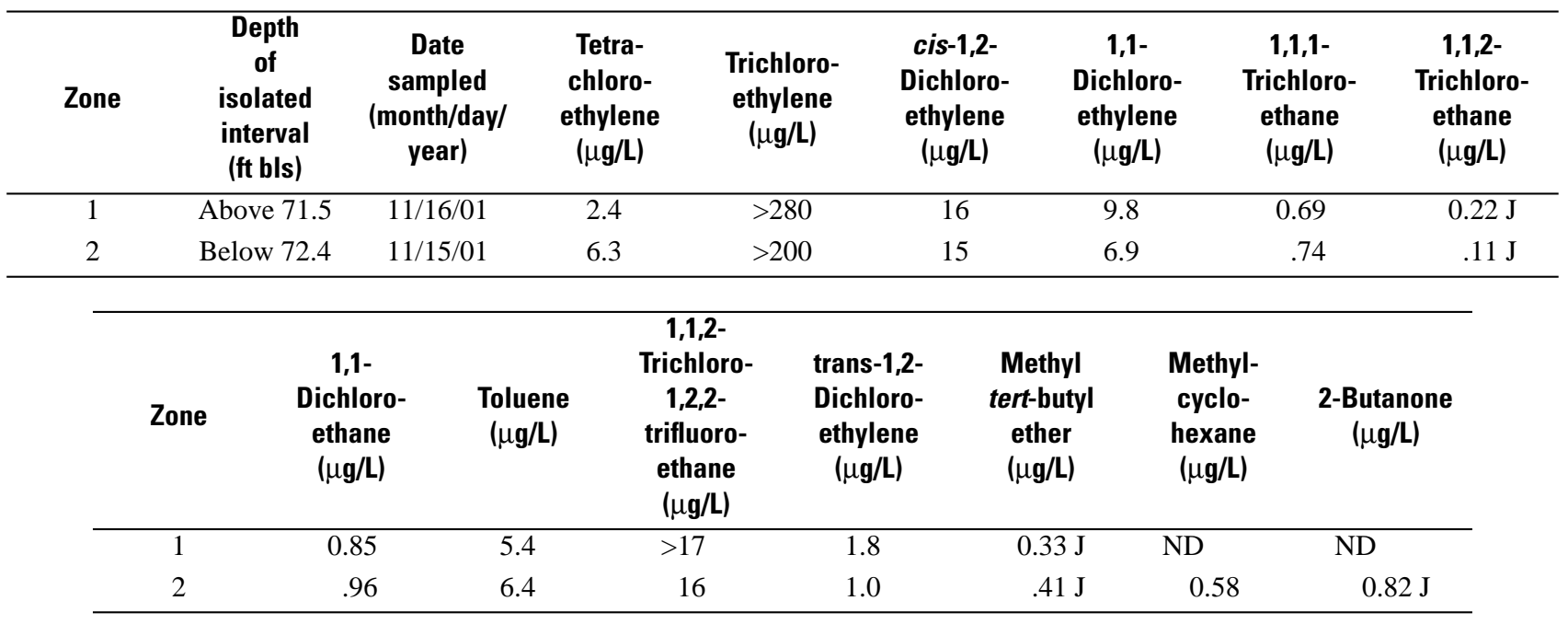

\section{Well MG-1842 (Teleflex T-15)}

Geophysical logging of well MG-1842 indicated probable water-bearing zones in the intervals between 48 and 51, 66 and 78, and 78 and $86 \mathrm{ft}$ bls. The water-bearing zones correspond to fractures detected in these intervals on the caliper log (fig. 24). When the well was pumped for heatpulse-flowmeter measurements, the intervals between 66-78 and 78-86 ft bls were apparently the most productive. Two intervals were, subsequently, selected for isolation based on the results of geophysical logging (zones 1 and 2, table 52). Single-packer configurations were used for tests of both zones 1 and 2. An additional interval was indicated by results of geophysical logging near $78 \mathrm{ft}$ bls; however, because of space restrictions near the bottom of the well, this isolation test was not possible.

Table 52. Isolated intervals tested in well MG-1842 (T-15), North Penn Area 7 Superfund site, Upper Gwynedd Township, Montgomery County, Pa., November 2001.

[ft bls, feet below land surface]

\begin{tabular}{ccc}
\hline Zone & $\begin{array}{c}\text { Depth of } \\
\text { isolated } \\
\text { interval } \\
\text { (ft bls) }\end{array}$ & $\begin{array}{c}\text { Date of test } \\
\text { (month/day/year) }\end{array}$ \\
\hline 1 & Above 67 & $11 / 14 / 01$ \\
2 & Below 66.5 & $11 / 14 / 01$ \\
\hline
\end{tabular}

Tests of the two zones showed the interval above $67 \mathrm{ft}$ bls was not connected hydraulically to the interval below $67 \mathrm{ft}$ bls ( $66.5 \mathrm{ft}$ bls for zone 2 test), as indicated by head separation (difference in water levels) after packer inflation and no observed response to pumping stress within isolated intervals adjacent to pumped intervals (fig. 56). Where head separation occurred, the water level in the upper interval was higher than the water level in the lower interval, indicating a downward vertical gradient and, subsequently, downward flow within the borehole. Downward vertical flow was measured within the borehole, under nonpumping conditions, at the time of geophysical logging, although this downward flow was only detected at $78 \mathrm{ft}$ bls and no downward flow was detected at the depths of 46, 54, or $66 \mathrm{ft}$ bls.

Results from the isolation tests indicate at least two hydraulically isolated intervals in the well-above $67 \mathrm{ft}$ bls and below $66.5 \mathrm{ft}$ bls. Specific capacity computed for the entire well (open hole) during geophysical logging produced a value similar $[3.89(\mathrm{gal} / \mathrm{min}) / \mathrm{ft}]$ to the sum of the specific capacities of the productive zones determined by isolation tests [4.16 (gal/min)/ft] (table 53).

Physical and chemical properties of water pumped from isolated intervals and measured near the end of pumping are listed in table 54. The $\mathrm{pH}$, dissolved-oxygen concentration, temperature, and specific conductance of water from the isolated intervals of well MG-1842 were similar (fig. 57; table 54). In general, the $\mathrm{pH}$ was near neutral (ranging from 7.50 to 7.58 standard units) and the dissolved-oxygen concentrations were relatively high (both intervals measured $3.6 \mathrm{mg} / \mathrm{L}$ ) compared to those properties in water from other wells in the study. Results of laboratory analyses (table 55) indicate concentrations of VOCs are similar in water samples collected from the isolated intervals. A few more compounds and generally slightly higher concentrations were detected in samples from the interval above $67 \mathrm{ft}$ bls than in samples from the interval below $66.5 \mathrm{ft}$ bls. TCE, 1,1-DCE, and 1,1,2trichloro-1,2,2-trifluoroethane were the compounds detected at the highest concentrations. 

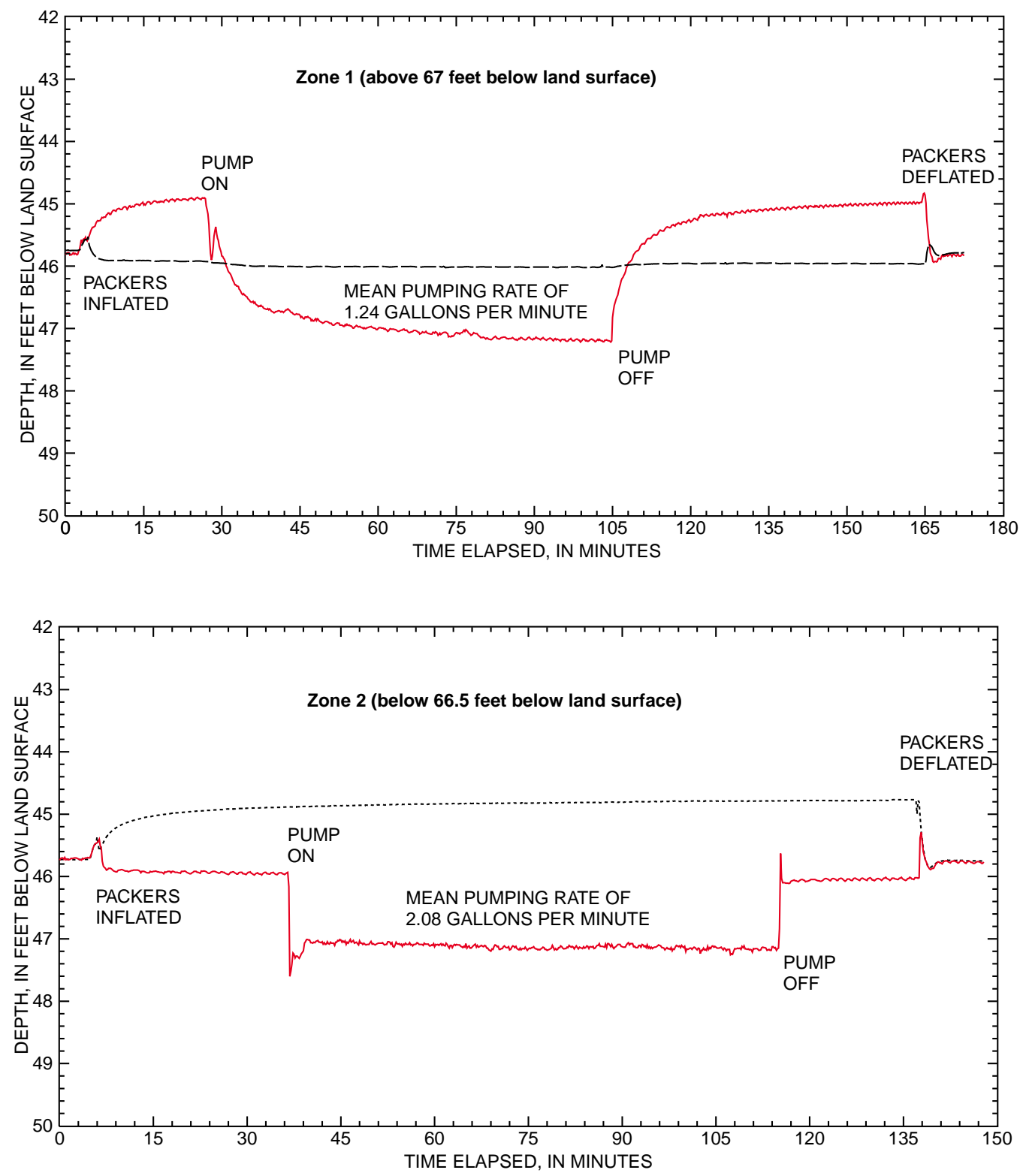

\section{EXPLANATION}

WATER LEVEL ABOVE THE ISOLATED INTERVAL

WATER LEVEL IN THE ISOLATED INTERVAL

WATER LEVEL BELOW THE ISOLATED INTERVAL

Figure 56. Depth to water above isolated interval, in isolated interval, and below isolated interval before, during, and after pumping for tests of isolated intervals zone 1 (above 67 feet below land surface) and zone 2 (below 66.5 feet below land surface) in well MG-1842 (T-15), North Penn Area 7 Superfund site, Upper Gwynedd Township, Montgomery County, Pa., November 14, 2001. 
Table 53. Depths, water levels, and specific capacity of aquifer intervals isolated by packers for well MG-1842 (T-15), North Penn Area 7 Superfund site, Upper Gwynedd Township, Montgomery County, Pa.

[ft bls, feet below land surface; ft, feet; gal/min, gallons per minute; min, minutes; (gal/min)/ft, gallons per minute per foot; $\mathrm{ft}^{2} / \mathrm{d}$, feet squared per day; --, no data]

\begin{tabular}{|c|c|c|c|c|c|c|c|c|}
\hline $\begin{array}{l}\text { Depth } \\
\text { of } \\
\text { isolated } \\
\text { interval } \\
\text { (ft bls) }\end{array}$ & $\begin{array}{c}\text { Date } \\
\text { of } \\
\text { test } \\
\text { (month/day/ } \\
\text { year) }\end{array}$ & $\begin{array}{c}\text { Depth } \\
\text { to water in } \\
\text { interval at } \\
\text { beginning } \\
\text { of test }{ }^{1} \\
\text { (ft bls) }\end{array}$ & $\begin{array}{c}\text { Depth } \\
\text { to water } \\
\text { in interval } \\
\text { at end } \\
\text { of test }{ }^{2} \\
\text { (ft bls) }\end{array}$ & $\begin{array}{c}\text { Drawdown } \\
\text { (ft) }\end{array}$ & $\begin{array}{c}\text { Mean } \\
\text { pumping } \\
\text { rate } \\
\text { (gal/min) }\end{array}$ & $\begin{array}{l}\text { Pumping } \\
\text { duration } \\
\text { (min) }\end{array}$ & $\begin{array}{c}\text { Specific } \\
\text { capacity } \\
{[(\text { gal/min }) / f t]}\end{array}$ & $\begin{array}{c}\text { Trans- } \\
\text { missivity } \\
\left(\mathrm{ft}^{2} / \mathrm{d}\right)\end{array}$ \\
\hline \multicolumn{9}{|c|}{ Zone 1 (above $67 \mathrm{ft}$ bls) } \\
\hline Above 67 (pumped) & $11 / 14 / 01$ & 44.90 & 47.20 & 2.30 & 1.24 & 77.83 & 0.54 & 119 \\
\hline Below 67 & $11 / 14 / 01$ & 45.93 & 46.02 & .09 & -- & -- & -- & -- \\
\hline \multicolumn{9}{|c|}{ Zone 2 (below $66.5 \mathrm{ft} \mathrm{bls)}$} \\
\hline Above 66.5 & $11 / 14 / 01$ & 44.88 & 44.79 & -.11 & -- & -- & -- & -- \\
\hline $\begin{array}{l}\text { Below } 66.5 \\
\text { (pumped) }\end{array}$ & $11 / 14 / 01$ & 46.26 & 46.84 & .58 & 2.08 & 68.16 & 3.62 & 789 \\
\hline Sum of specific capa & cities or trans & nissivities for & nes tested & & & & 4.16 & 908 \\
\hline \multicolumn{9}{|c|}{ Open-hole tests } \\
\hline Open hole & $10 / 10 / 01$ & 41.18 & 41.46 & .28 & 1.09 & 27 & 3.89 & 857 \\
\hline
\end{tabular}

Table 54. Inorganic water-quality constituents and physical properties for samples collected from isolated intervals in well MG-1842 (T-15), North Penn Area 7 Superfund site, Upper Gwynedd Township, Montgomery County, Pa.

[ft bls, feet below land surface; mg/L, milligrams per liter; ${ }^{\circ} \mathrm{C}$, degrees Celsius, $\mu \mathrm{S} / \mathrm{cm}$ at $25{ }^{\circ} \mathrm{C}$, microsiemens per centimeter at 25 degrees Celsius]

\begin{tabular}{|c|c|c|c|c|c|c|c|}
\hline Zone & $\begin{array}{c}\text { Depth } \\
\text { of } \\
\text { isolated } \\
\text { interval } \\
\text { (ft bls) }\end{array}$ & $\begin{array}{c}\text { Date } \\
\text { sampled } \\
\text { (month/day/ } \\
\text { year) }\end{array}$ & Time & $\begin{array}{c}\text { pH } \\
\text { (standard } \\
\text { units) }\end{array}$ & $\begin{array}{c}\text { Dis- } \\
\text { solved } \\
\text { oxygen } \\
(\mathrm{mg} / \mathrm{L})\end{array}$ & $\begin{array}{c}\text { Tempera- } \\
\text { ture } \\
\left({ }^{\circ} \mathrm{C}\right)\end{array}$ & $\begin{array}{c}\text { Specific } \\
\text { conductance } \\
(\mu \mathrm{S} / \mathrm{cm} \\
\left.\text { at } 25^{\circ} \mathrm{C}\right)\end{array}$ \\
\hline 1 & Above 68 & $11 / 14 / 01$ & 1559 & 7.58 & 3.6 & 13.9 & 628 \\
\hline 2 & $66-86$ & $11 / 14 / 01$ & 1249 & 7.5 & 3.6 & 13.7 & 645 \\
\hline
\end{tabular}




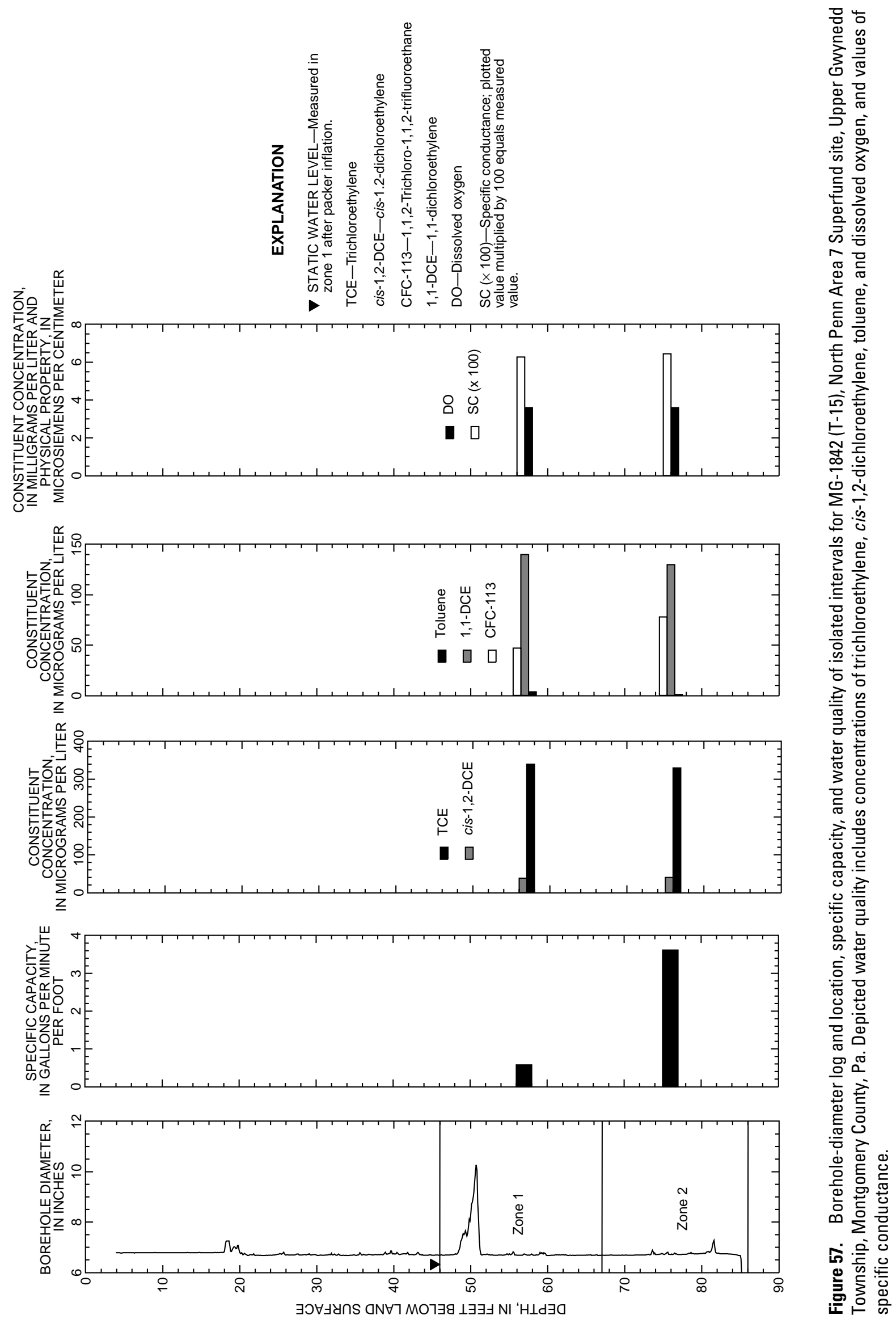


Table 55. Selected volatile organic compound concentrations in water samples from isolated intervals in well MG-1842 (T-15), North Penn Area 7 Superfund site, Upper Gwynedd Township, Montgomery County, Pa. (Laboratory results provided by CDM Federal Programs Corporation.)

[ft bls, feet below land surface; $\mu \mathrm{g} / \mathrm{L}$, micrograms per liter; >, greater than; ND, not detected; J, compound present—reported value may not be accurate or precise]

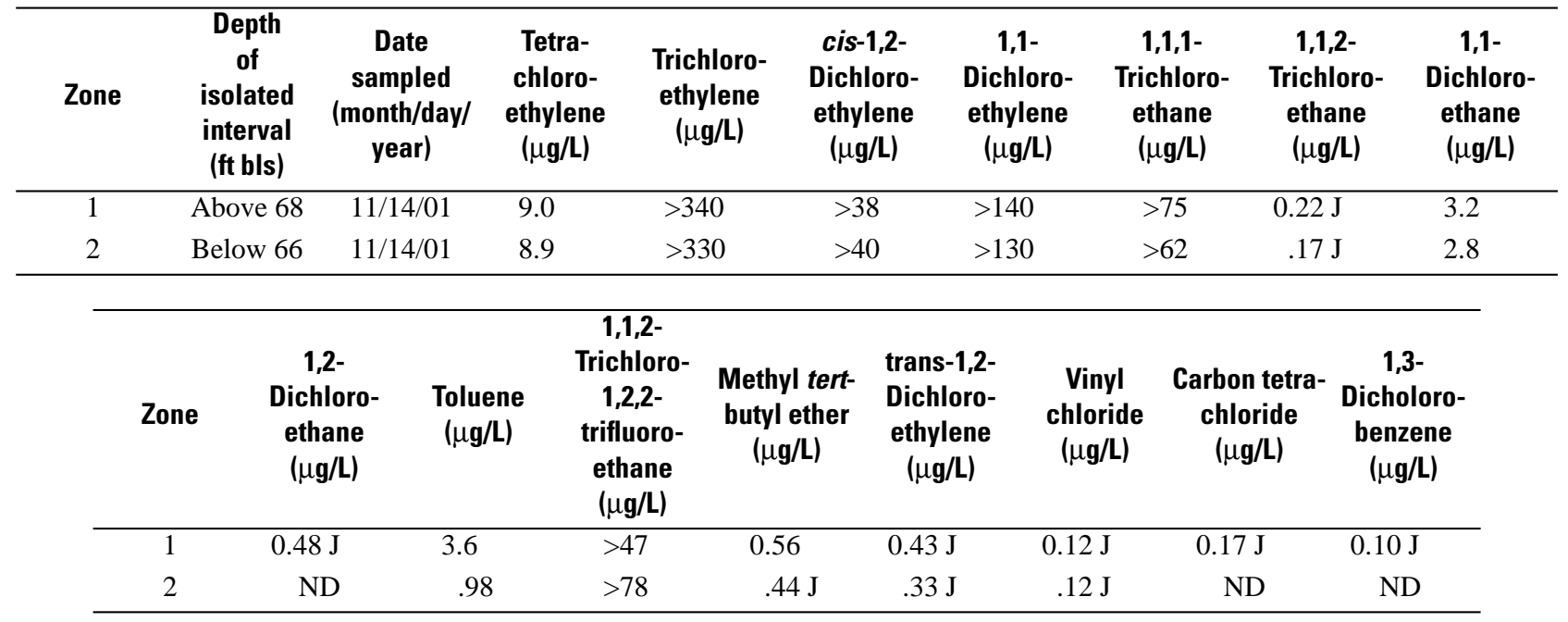

\section{Well MG-1897 (Clearline 3)}

Geophysical logging of well MG-1897 indicated probable water-bearing zones in the intervals 40-50, 58-72, 72-88, 96-112, 170-186, and 190-220 ft bls. The water-bearing zones correspond to fractures detected in these intervals on the caliper log (fig. 30). When the well was pumped for heatpulse-flowmeter measurements, the intervals between 40 and 50, 72 and 88, and 96 and $112 \mathrm{ft}$ bls apparently were the most productive. Four intervals (zones 1-4, table 56) were selected for isolation based on results of geophysical logging and direct observation of borehole condition by borehole video survey. The spacing between the mid-points of the packers was $15 \mathrm{ft}$ for all zones.

Table 56. Isolated intervals tested in well MG-1897 (Clearline 3), North Penn Area 7 Superfund site, Upper Gwynedd Township, Montgomery County, Pa., November 2001.

[ft bls, feet below land surface]

\begin{tabular}{ccc}
\hline Zone & $\begin{array}{c}\text { Depth } \\
\text { of } \\
\text { isolated } \\
\text { interval } \\
\text { (ft bls) }\end{array}$ & $\begin{array}{c}\text { Date } \\
\text { of } \\
\text { test } \\
\text { (month/day/year) }\end{array}$ \\
\hline 1 & Above 56 & $11 / 6 / 01$ \\
2 & $56-71$ & $11 / 7 / 01$ \\
3 & $93-108$ & $11 / 8 / 01$ \\
4 & Below 147 & $11 / 9 / 01$ \\
\hline
\end{tabular}

The productive interval between 72 and $88 \mathrm{ft}$ bls was not tested because this interval could not be isolated by packers because of the physical condition of the borehole wall in the range of 72-88 ft bls. Intervals below $184 \mathrm{ft}$ bls were not isolated because of a reduction in borehole diameter from 10 to 8 in. at that depth. Slight deviations from vertical are common in most wells; this deviation causes the packer assembly to press against the borehole wall (foot wall) and makes it impossible to lower the packers past the "step" caused by the reduction in borehole size.

The test of zone 1 (above $56 \mathrm{ft}$ bls) indicated that, based on the lack of water-level response rather than head separation, the interval below $56 \mathrm{ft}$ bls was isolated hydraulically from the pumped interval above $56 \mathrm{ft}$ bls (fig. 58). The test of zones 2 and 3, with pumped intervals of 56-71 and 93-

$108 \mathrm{ft}$ bls, respectively, also indicated both pumped intervals were isolated hydraulically from the intervals above and below based on lack of water-level response in intervals adjacent to the pumped interval (figs. 58 and 59). The test of zone 4 indicated the interval above $147 \mathrm{ft}$ bls was isolated hydraulically from the pumped interval below $147 \mathrm{ft}$ bls (fig. 59).

Tests of each of the four intervals showed that, despite little head separation after packer inflation, none of the intervals were connected either inside or outside the borehole as the result of inadequate packer seal or aquifer properties. Where head separation occurred (only in zone 4), the water level in the lower interval was higher than the upper interval, indicating an upward vertical gradient. Upward vertical flow was measured in the borehole under nonpumping conditions at the time of geophysical logging. 

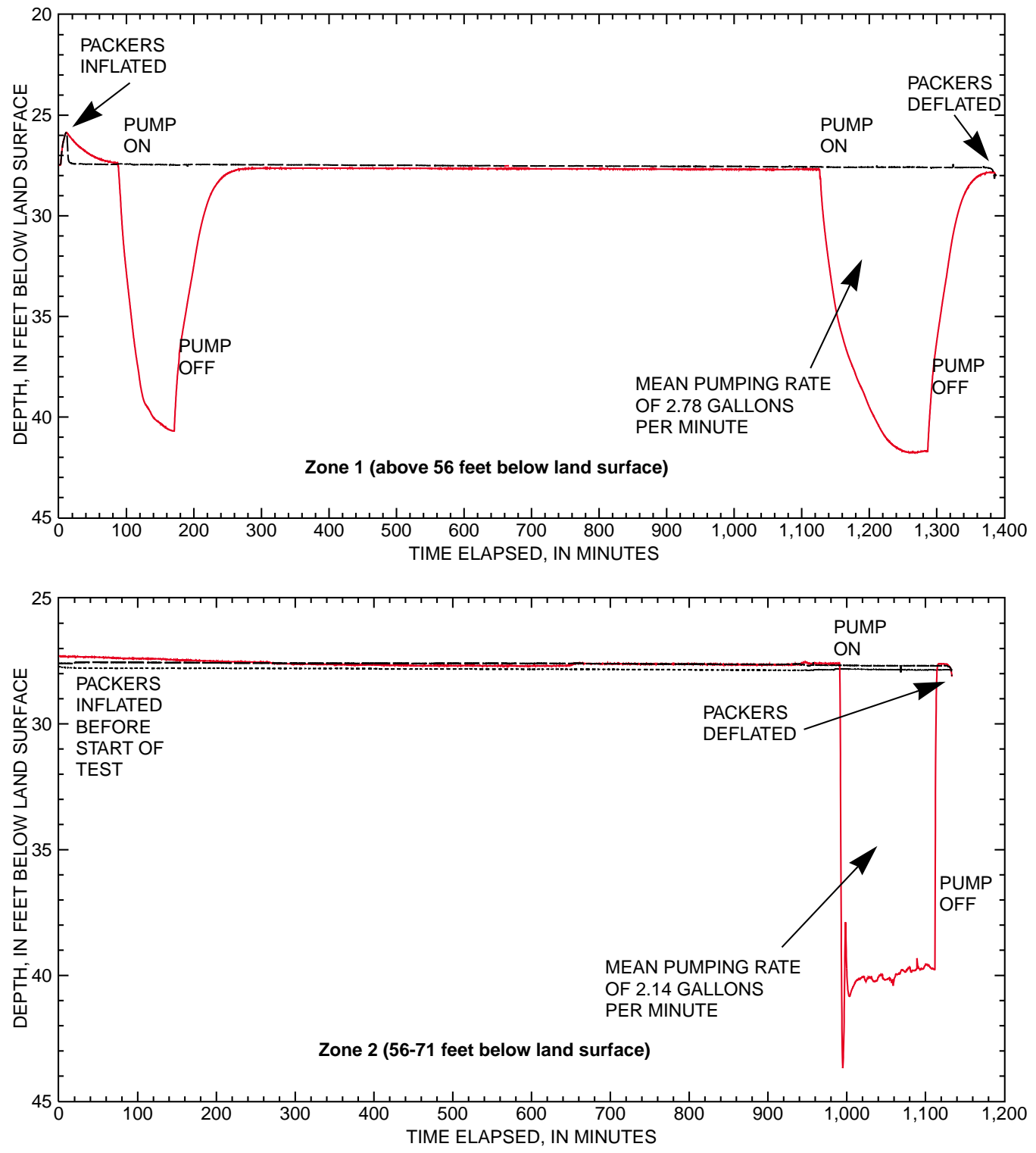

EXPLANATION

WATER LEVEL ABOVE THE ISOLATED INTERVAL

WATER LEVEL IN THE ISOLATED INTERVAL

WATER LEVEL BELOW THE ISOLATED INTERVAL

Figure 58. Depth to water above isolated interval, in isolated interval, and below isolated interval before, during, and after pumping for tests of isolated intervals zone 1 (above 56 feet below land surface) and zone 2 (between 56 and 71 feet below land surface) in well MG-1897 (Clearline 3), North Penn Area 7 Superfund site, Upper Gwynedd Township, Montgomery County, Pa., November 6-7, 2001. 

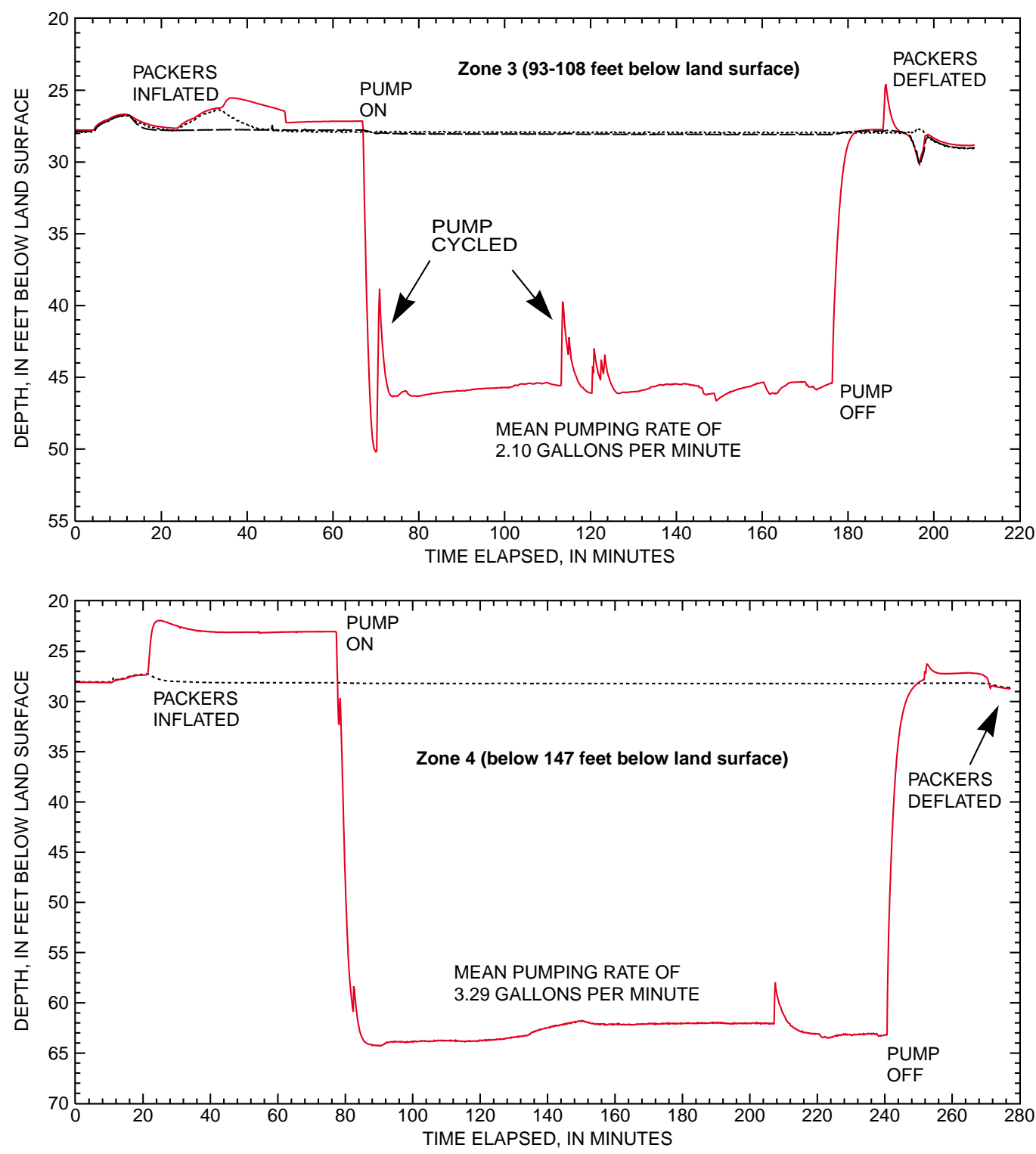

\section{EXPLANATION}

WATER LEVEL ABOVE THE ISOLATED INTERVAL

WATER LEVEL IN THE ISOLATED INTERVAL

WATER LEVEL BELOW THE ISOLATED INTERVAL

Figure 59. Depth to water above isolated interval, in isolated interval, and below isolated interval before, during, and after pumping for tests of isolated intervals zone 3 (between 93-108 feet below land surface) and zone 4 (below 147 feet below land surface) in well MG-1897 (Clearline 3), North Penn Area 7 Superfund site, Upper Gwynedd Township, Montgomery County, Pa., November 8-9, 2001. 
Results from the isolation test indicate at least four hydraulically isolated intervals in the well-above $56 \mathrm{ft}$ bls (zone 1 test), 56-71 ft bls (zone 2 test), 93-108 ft bls (zone 3 test), and below $147 \mathrm{ft}$ bls (zone 4 test). The intervals above $147 \mathrm{ft}$ bls have higher specific capacities than the interval below $147 \mathrm{ft}$ bls (fig. 60; table 57). These data agree with the results obtained from geophysical logging. Production from the zone not tested (72-88 ft bls) probably accounts for the difference between the sum of specific capacities for zones tested and the open-hole specific capacity (table 57).

Physical and chemical properties of water pumped from isolated intervals and measured near the end of pumping are listed in table 58. The $\mathrm{pH}$, dissolved-oxygen concentration, temperature, specific conductance, and alkalinity of water from the isolated intervals in well MG-1897 generally were similar with the exception of zone 2 (fig. 60; table 58). Water from zone 2 had a higher concentration of dissolved oxygen
(1.4 mg/L) compared to water from the other zones, which had concentrations of dissolved oxygen ranging from 0.1 to $0.6 \mathrm{mg} /$ $\mathrm{L}$. The specific conductance in water from zone 2 (56-71 ft bls) $(612 \mu \mathrm{S} / \mathrm{cm})$ also was greater than values ranging from 474 to $561 \mu \mathrm{S} / \mathrm{cm}$ for the other zones. Water from all zones exhibited similar values for temperature $\left(12.0-12.6^{\circ} \mathrm{C}\right), \mathrm{pH}(7.25-7.80$ standard units), and alkalinity (169-185 mg/L). Results of laboratory analyses (table 59) indicate concentrations of VOCs differ in water samples collected from isolated intervals. More compounds and generally higher concentrations of VOCs were detected in samples from zones above $71 \mathrm{ft}$ bls than in samples from zones below that depth (fig. 60; table 59). Chloroform, TCE, and tolulene were the VOC compounds measured in the highest concentrations. Elevated chloroform concentrations may be related to the use of bleach in decontaminating the well after geophysical logging 3-5 days prior to aquifer-interval-isolation testing.

Table 57. Depths, water levels, drawdown, and specific capacity of aquifer intervals isolated by packers for well MG-1897 (Clearline 3), North Penn Area 7 Superfund site, Upper Gwynedd Township, Montgomery County, Pa.

[ft bls, feet below land surface; ft, feet; gal/min, gallons per minute; min, minutes; (gal/min)/ft, gallons per minute per foot; $\mathrm{ft}^{2} / \mathrm{d}$, feet squared per day; --, no data]

\begin{tabular}{|c|c|c|c|c|c|c|c|c|}
\hline $\begin{array}{l}\text { Depth } \\
\text { of } \\
\text { isolated } \\
\text { interval } \\
\text { (ft bls) }\end{array}$ & $\begin{array}{c}\text { Date } \\
\text { of } \\
\text { test } \\
\text { (month/day/ } \\
\text { year) }\end{array}$ & $\begin{array}{c}\text { Depth } \\
\text { to water in } \\
\text { interval at } \\
\text { beginning } \\
\text { of test }{ }^{1} \\
\text { (ft bls) }\end{array}$ & $\begin{array}{c}\text { Depth } \\
\text { to water } \\
\text { in interval } \\
\text { at end } \\
\text { of test }{ }^{2} \\
\text { (ft bls) }\end{array}$ & $\begin{array}{c}\text { Drawdown } \\
\text { (ft) }\end{array}$ & $\begin{array}{c}\text { Mean } \\
\text { pumping rate } \\
\text { (gal/min) }\end{array}$ & $\begin{array}{l}\text { Pumping } \\
\text { duration } \\
\text { (min) }\end{array}$ & $\begin{array}{c}\text { Specific } \\
\text { capacity } \\
{[(\text { gal/min)/ft] }}\end{array}$ & $\begin{array}{c}\text { Trans- } \\
\text { missivity } \\
\left.\text { (ft }{ }^{2} / \mathrm{d}\right)\end{array}$ \\
\hline \multicolumn{9}{|c|}{ Zone 1 (above $56 \mathrm{ft}$ bls) } \\
\hline Above 56 (pumped) $^{4}$ & $11 / 7 / 01$ & 27.70 & 41.71 & 14.01 & 2.78 & 160.0 & 0.20 & 40.5 \\
\hline Below 56 & $11 / 7 / 01$ & 27.57 & 27.59 & .02 & -- & -- & -- & -- \\
\hline \multicolumn{9}{|c|}{ Zone 2 (56-71 ft bls) } \\
\hline Above 56 & $11 / 7 / 01$ & 27.80 & 27.84 & .04 & -- & -- & -- & -- \\
\hline 56-71 (pumped) & $11 / 7 / 01$ & 27.60 & 39.76 & 12.16 & 2.14 & 121.0 & .18 & 36.0 \\
\hline Below 71 & $11 / 7 / 01$ & 27.67 & 27.68 & .01 & -- & -- & -- & -- \\
\hline \multicolumn{9}{|c|}{ Zone 3 (93-107 ft bls) } \\
\hline Above 93 & $11 / 8 / 01$ & 27.89 & 28.01 & .12 & -- & -- & -- & -- \\
\hline 93-108 (pumped) & $11 / 8 / 01$ & 27.62 & 43.10 & 15.48 & 2.10 & 107.5 & .14 & 27.7 \\
\hline Below 108 & $11 / 8 / 01$ & 27.75 & 28.09 & .34 & -- & -- & -- & -- \\
\hline \multicolumn{9}{|c|}{ Zone 4 (below $147 \mathrm{ft}$ bls) } \\
\hline Above 147 & $11 / 9 / 01$ & 28.13 & 28.22 & .09 & -- & -- & -- & -- \\
\hline Below 147 (pumped) ${ }^{5}$ & $11 / 9 / 01$ & 23.04 & 63.17 & 40.12 & 3.29 & 163.5 & .08 & 16.8 \\
\hline Sum of specific capacit & ities or transmi & ssivities for z & nes tested & & & & .60 & 121 \\
\hline \multicolumn{9}{|c|}{ Open-hole tests } \\
\hline Open hole & $10 / 24 / 01$ & 24.48 & 27.36 & 2.89 & 3.0 & 88 & 1.04 & 210 \\
\hline
\end{tabular}



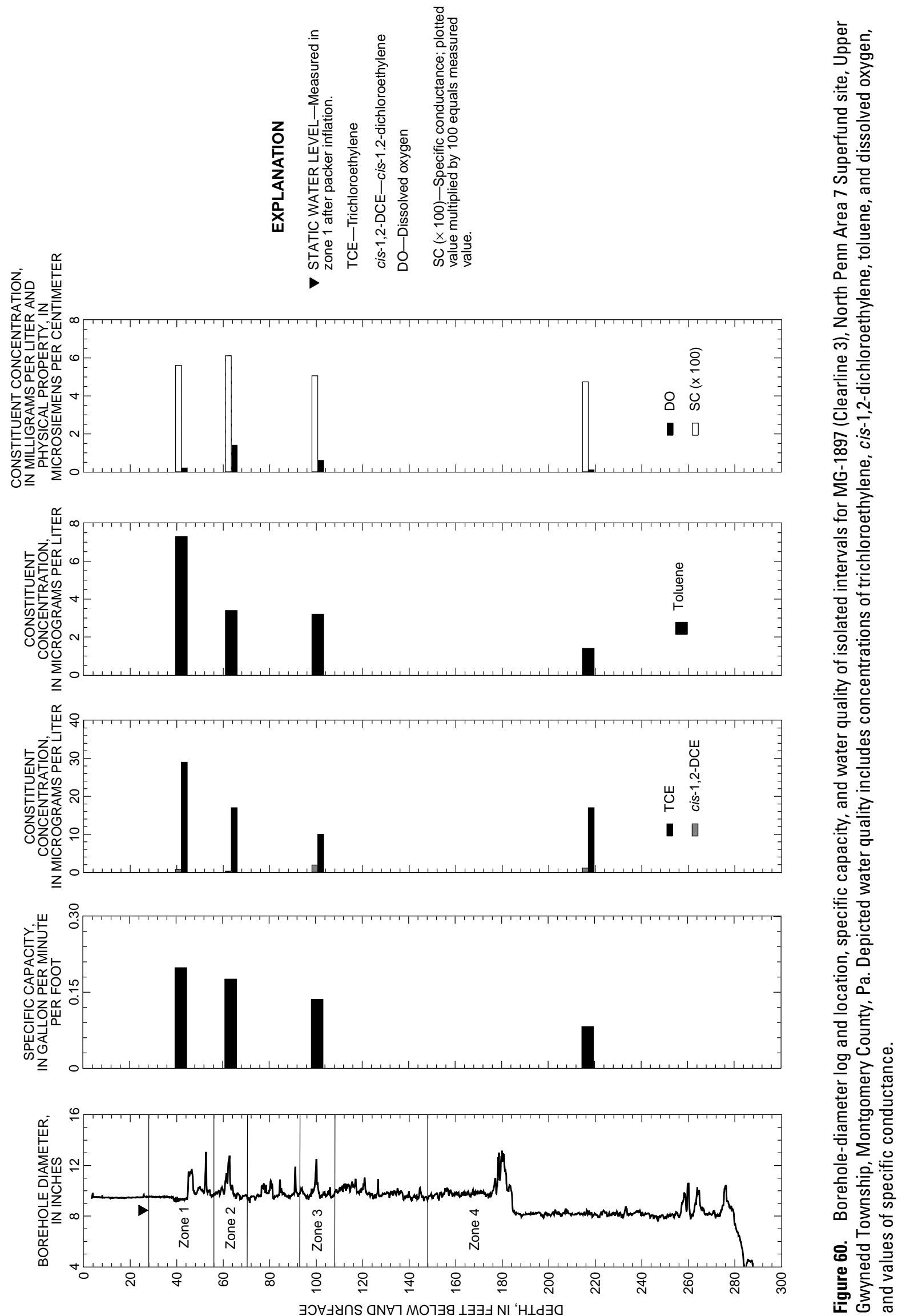
Table 58. Inorganic water-quality constituents and physical properties for samples collected from isolated intervals in well MG-1897 (Clearline 3), North Penn Area 7 Superfund site, Upper Gwynedd Township, Montgomery County, Pa.

[ft bls, feet below land surface; $\mathrm{mg} / \mathrm{L}$, milligrams per liter; ${ }^{\circ} \mathrm{C}$, degrees Celsius, $\mu \mathrm{S} / \mathrm{cm}$ at $25^{\circ} \mathrm{C}$, microsiemens per centimeter at 25 degrees Celsius; --, no data]

\begin{tabular}{|c|c|c|c|c|c|c|c|c|}
\hline Zone & $\begin{array}{l}\text { Depth } \\
\text { of } \\
\text { isolated } \\
\text { interval } \\
\text { (ft bls) }\end{array}$ & $\begin{array}{c}\text { Date } \\
\text { sampled } \\
\text { (month/day/ } \\
\text { year) }\end{array}$ & Time & $\begin{array}{c}\text { pH } \\
\text { (standard } \\
\text { units) }\end{array}$ & $\begin{array}{l}\text { Dissolved } \\
\text { oxygen } \\
\text { (mg/L) }\end{array}$ & $\begin{array}{c}\text { Water } \\
\text { temperature } \\
\left({ }^{\circ} \mathrm{C}\right)\end{array}$ & $\begin{array}{c}\text { Specific } \\
\text { conductance } \\
(\mu \mathrm{S} / \mathrm{cm} \\
\left.\text { at } 25^{\circ} \mathrm{C}\right)\end{array}$ & $\begin{array}{c}\text { Alkalinity } \\
\text { (mg/L) }\end{array}$ \\
\hline 1 & Above 56 & $11 / 7 / 01$ & 1104 & 7.25 & 0.2 & 12.3 & 561 & 185 \\
\hline 2 & 56-71 & $11 / 8 / 01$ & 1040 & 7.58 & 1.4 & 12.1 & 612 & -- \\
\hline 3 & 93-108 & $11 / 8 / 01$ & 1549 & 7.47 & .6 & 12.0 & 506 & $169-170$ \\
\hline 4 & Below 147 & $11 / 9 / 01$ & 1340 & 7.8 & .1 & 12.6 & 474 & 178 \\
\hline
\end{tabular}

Table 59. Selected volatile organic compound concentrations in water samples from isolated intervals in well MG-1897 (Clearline 3), North Penn Area 7 Superfund site, Upper Gwynedd Township, Montgomery County, Pa. (Laboratory results provided by CDM Federal Programs Corporation.)

[ft bls, feet below land surface; $\mu \mathrm{g} / \mathrm{L}$, micrograms per liter; >, greater than; ND, not detected; J, compound present-reported value may not be accurate or precise; L, compound present—reported value may be biased low; K, compound present—reported value may be biased high]

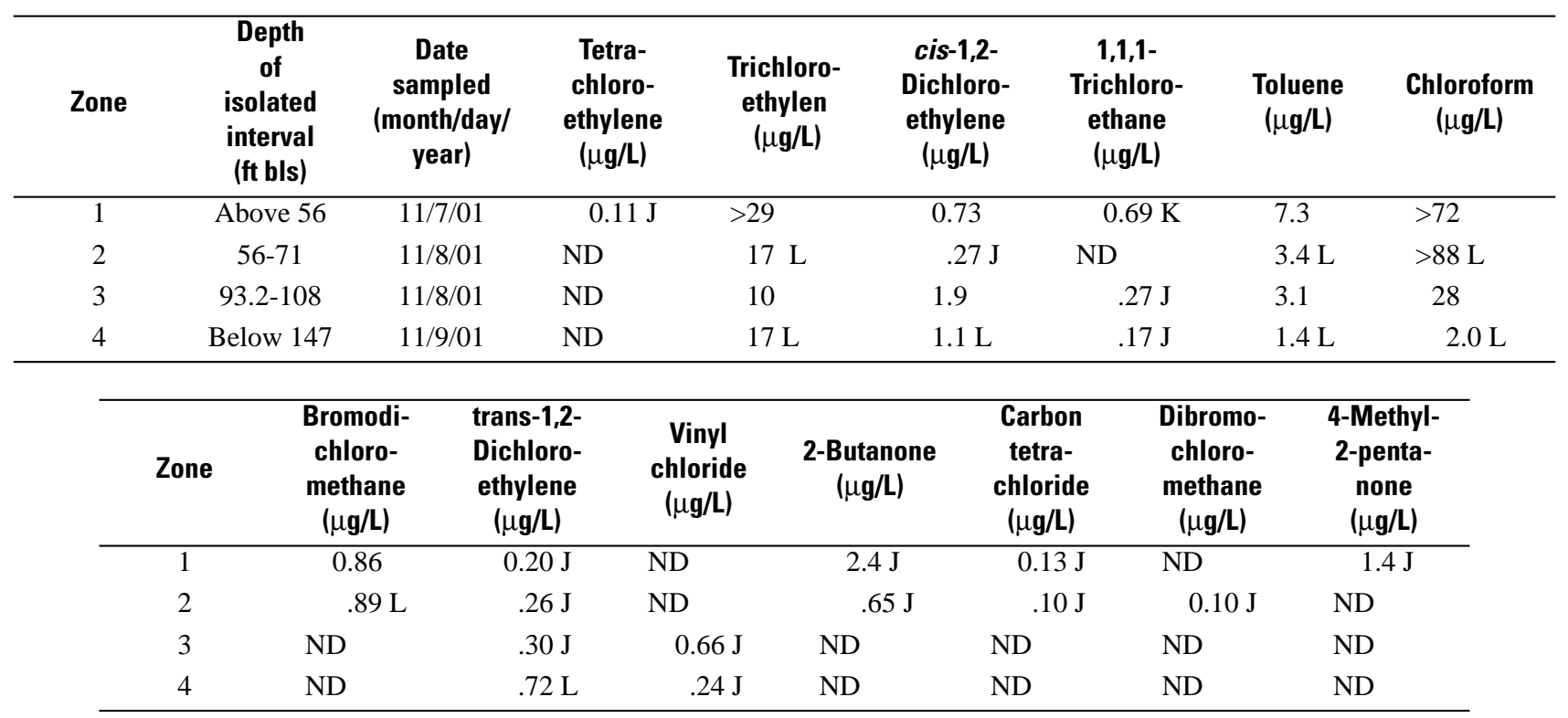




\section{Discussion of Single-Well, Aquifer-Interval-Isolation- Test Results}

Single-well, aquifer-interval-isolation tests done at nine wells (table 60) in and near North Penn Area 7 generally indicate that (1) discrete water-bearing zones are not well-connected in the vertical direction; (2) specific capacity and estimated transmissivity ranged over two to three orders of magnitude in the water-bearing zones tested; (3) TCE, cis-1,2DCE, and toluene frequently are the compounds measured in highest concentrations; and (4) highest concentrations of VOCs, except for toluene, generally are from the shallowest isolated intervals.

Evidence for limited vertical hydraulic connection between water-bearing openings includes differences in static potentiometric head (water level) up to $31 \mathrm{ft}$ between isolated intervals in a borehole and typically small drawdown in zones adjacent to the isolated pumped zone. No relation between depth and specific capacity or estimated transmissivity was noted in the results of tests of isolated zones in the nine wells (although data were limited because only four of the wells tested were greater than $100 \mathrm{ft}$ deep). Specific capacity determined from tests of isolated intervals ranged from 0.02 to 3.63 (gal/min)/ft (table 60).

Maximum concentrations of the most frequently detected VOCs in water samples from the isolated intervals-TCE, cis1,2-DCE, and toluene-are shown in table 60. Concentrations of TCE generally were greater than other compounds detected except in samples from well MG-175, in which concentrations of cis-1,2-DCE; toluene; and vinyl chloride were higher (table 31). In the nine wells tested, the highest concentration of TCE measured was greater than $340 \mu \mathrm{g} / \mathrm{L}$ in water from an isolated interval in well MG-1842 on the Teleflex property (table 60). Samples from wells on the Teleflex property contained numerous VOCs other than TCE; cis-1,2-DCE; and toluene, including PCE and 1,1,2-trichloro-1,2,2-trifluoroethane.

For each well, the concentrations of TCE and most VOCs commonly were highest in samples from the shallowest isolated interval, except for wells MG-202 (table 35) and MG-1146 (table 47). In MG-202 and MG-1146, the highest concentrations of TCE were measured in samples from the next deepest isolated interval below the shallowest isolated interval. Concentrations of toluene also were highest in samples from the intervals deeper than the shallowest isolated interval in five wells (MG-175, MG-202, MG-1144, MG-1146, and MG-1147).

The dissolved-oxygen concentrations of water samples from the isolated intervals generally were low, ranging from 0.1 to $3.6 \mathrm{mg} / \mathrm{L}$. Low dissolved-oxygen concentrations in ground water may indicate the presence of reducing conditions associated with degradation of VOCs. Additional evidence for VOC degradation is the widespread occurrence of cis-1,2DCE, a degradation product of TCE (Bower and McCarty, 1983). In samples from MG-175, high concentrations of vinyl chloride were measured, indicating further degradation from TCE and cis-1,2-DCE.

Table 60. Minimum and maximum specific capacity of isolated intervals and maximum concentrations of selected volatile organic compounds in water samples from isolated intervals in eight wells tested using aquifer-interval-isolation methods in the vicinity of the North Penn Area 7 Superfund site, Upper Gwynedd Township, Montgomery County, Pa., September 2001 through May 2002.

$[(\mathrm{gal} / \mathrm{min}) / \mathrm{ft}$, gallons per minute per foot; min., minimum; max., maximum; $\mu \mathrm{g} / \mathrm{L}$, micrograms per liter; ft bls, feet below land surface; VOC, volatile organic compound; TCE, trichloroethylene; cis-1,2-DCE, cis-1,2-dichloroethylene; >, greater than; <, less than]

\begin{tabular}{|c|c|c|c|c|c|c|c|c|c|}
\hline \multirow{2}{*}{$\begin{array}{c}\text { U.S. } \\
\text { Geological } \\
\text { Survey } \\
\text { local well } \\
\text { number }\end{array}$} & \multirow{2}{*}{$\begin{array}{l}\text { Owner } \\
\text { well } \\
\text { name }\end{array}$} & \multirow{2}{*}{$\begin{array}{l}\text { Well } \\
\text { depth', } \\
\text { in feet }\end{array}$} & \multirow{2}{*}{$\begin{array}{l}\text { Number } \\
\text { of zones } \\
\text { tested }\end{array}$} & \multicolumn{2}{|c|}{$\begin{array}{l}\text { Specific capacity of } \\
\text { isolated intervals, } \\
\text { in }(\mathrm{gal} / \mathrm{min}) / \mathrm{ft}\end{array}$} & \multicolumn{3}{|c|}{$\begin{array}{c}\text { Maximum concentration of VOC } \\
\text { in isolated-interval sample, } \\
\text { in } \mu \mathrm{g} / \mathrm{L}\end{array}$} & \multirow{2}{*}{$\begin{array}{c}\text { Depth of } \\
\text { maximum } \\
\text { TCE concen- } \\
\text { tration, } \\
\text { in ft bls }\end{array}$} \\
\hline & & & & Min. & Max. & TCE & cis-1,2-DCE & Toluene & \\
\hline MG-174 & Clearline 2 & 160 & 6 & 0.11 & 0.70 & 99 & 75 & 14 & $68-82$ \\
\hline MG-175 & Spra-Fin 1 & 103 & 3 & .19 & 1.93 & 56 & 680 & $>590$ & above 72 \\
\hline MG-1145 & $\mathrm{T}-14$ & 83 & 3 & $<.14$ & .72 & 1.4 & .18 & 12 & above 47 \\
\hline MG-1146 & $\mathrm{T}-4$ & 84.5 & 2 & .02 & .20 & $>170$ & 13 & 19 & below 64 \\
\hline MG-1147 & $\mathrm{T}-11$ & 83.5 & 2 & .09 & .19 & $>280$ & 16 & 6.4 & above 71.5 \\
\hline MG-1842 & $\mathrm{T}-15$ & 86 & 2 & .54 & 3.62 & $>340$ & $>40$ & 3.6 & above 68 \\
\hline MG-1897 & Clearline 3 & 288 & 4 & .08 & .20 & $>29$ & 1.9 & 7.3 & above 56 \\
\hline
\end{tabular}

\footnotetext{
${ }^{1}$ Depth determined from geophysical logs.
} 


\section{Multiple-Well Test}

The removal and replacement of a pump in production well MG-202 during the winter of 2001-2002 provided an opportunity to monitor water-level responses in multiple observation wells and identify hydraulic connections in the vicinity of the pumped well. The pump was removed in December 2001 and replaced in January 2002. The pump was tested for 2-4 hours on February 20 and between February 22 and 23, 2002, and then started for continuous operation on March 5, 2002. Another production well, MG-76, near MG-202 was shut down briefly from February 23 to February 25, 2002, but typically is pumped continuously at a rate of about $79 \mathrm{gal} / \mathrm{min}$. A schedule of pumping rates and times is listed in table 61. During a period from mid-February to late March 2002, water levels in the vicinity of production well MG-202 were monitored continuously at nine well locations (fig. 61; table 62), two of which (MG-135 and MG-147) consisted of reconstructed wells with nests of up to four 2-in. diameter wells open at selected intervals (table 62). A total of 14 wells were monitored.

During the period from February through March 2002, when ground-water levels were monitored near well MG-202, other wells in the area were pumped intermittently and continuously for industrial use. Other pumping wells and pumping rates included MG-1841 (fig. 61) at a rate of about $4.5 \mathrm{gal} / \mathrm{min}$ and MG-171 and MG-204 (fig. 61) at a combined rate of $9 \mathrm{gal} / \mathrm{min}$. Farther to the west and southwest of North Penn Area 7, wells at Lehigh Valley Dairies (fig. 61) were pumped at a combined rate about $200 \mathrm{gal} / \mathrm{min}$ (approximately 300,000 gal/d) and wells at Merck \& Co. (fig. 61) were pumped at a combined rate of about $700 \mathrm{gal} / \mathrm{min}$ (approximately 1 $\mathrm{Mgal} / \mathrm{d})$.
Table 62. Well depth and altitude of open intervals in wells MG-202 and in wells with continuous water-level monitoring during periods of pumping well MG-202, February and March 2002, in the vicinity of North Penn Area 7 Superfund site, Upper Gwynedd Township, Montgomery County, Pa.

[NGVD 29, National Geodetic Vertical Datum of 1929; --, no data]

\begin{tabular}{ccccc}
\hline $\begin{array}{c}\text { U.S. } \\
\text { Geological } \\
\text { Survey } \\
\text { local well } \\
\text { number }\end{array}$ & $\begin{array}{c}\text { Owner } \\
\text { well } \\
\text { name }\end{array}$ & $\begin{array}{c}\text { Well } \\
\text { depth } \\
\text { (feet below } \\
\text { land surface) }\end{array}$ & $\begin{array}{c}\text { Altitude } \\
\text { of top } \\
\text { of open } \\
\text { interval } \\
\text { (feet above } \\
\text { NGVD 29) }\end{array}$ & $\begin{array}{c}\text { Altitude } \\
\text { of bottom } \\
\text { of open } \\
\text { interval } \\
\text { (feet above } \\
\text { NGVD 29) }\end{array}$ \\
\hline MG-202 & L-22 & 623 & 312 & -271 \\
MG-72 & L-13 & 298 & 313.1 & 57.1 \\
MG-174 & Clearline 2 & 160 & 273.7 & 186.7 \\
MG-175 & Spra-Fin 1 & 103 & 347.3 & 258.3 \\
MG-1897 & Clearline 3 & 288 & 292.2 & 48.2 \\
MG-1848 & MW3 & 55 & 309.3 & 294.3 \\
MG-1849 & -- & 50 & 313.0 & 298 \\
MG-1146 & T-4 & 84.5 & 325.3 & 259.3 \\
MG-147 & Ford 4.1 & 297 & 305 & 280 \\
& Ford 4.2 & 2125 & 262 & 252 \\
& Ford 4.3 & 2207 & 205 & 170 \\
& Ford 4.4 & 2392 & 20 & -15 \\
MG-135 & Ford 3.2 & 2301 & 106 & 66 \\
& Ford 3.3 & 2373 & 34 & -6 \\
& Ford 3.4 & 2427 & -30 & -60 \\
\hline
\end{tabular}

\footnotetext{
${ }^{1}$ Depth determined from geophysical logs.
}

${ }^{2}$ Depth to bottom of screened interval.

Table 61. Schedule and rates of pumping for wells MG-202 and MG-76, North Penn Area 7 Superfund site, Upper Gwynedd Township, Montgomery County, Pa., February and March 2002.

[gal/min, gallons per minute; cont.; continuous operation; >, greater than; --, no data]

\begin{tabular}{|c|c|c|c|c|c|c|}
\hline $\begin{array}{c}\text { U.S. } \\
\text { Geological } \\
\text { Survey } \\
\text { local well } \\
\text { number }\end{array}$ & $\begin{array}{c}\text { Start } \\
\text { date } \\
\text { (month/day/ } \\
\text { year) }\end{array}$ & $\begin{array}{l}\text { Start } \\
\text { time }\end{array}$ & $\begin{array}{c}\text { End } \\
\text { date } \\
\text { (month/day/ } \\
\text { year) }\end{array}$ & $\begin{array}{l}\text { End } \\
\text { time }^{1}\end{array}$ & $\begin{array}{c}\text { Pumping rate } \\
\text { (gal/min) }\end{array}$ & $\begin{array}{c}\text { Pumping } \\
\text { duration } \\
\text { (hours) }\end{array}$ \\
\hline \multirow[t]{3}{*}{ MG-202 } & $2 / 20 / 02$ & 1000 & $2 / 20 / 02$ & 1315 & 125 & 3.25 \\
\hline & $2 / 22 / 02$ & 0350 & $2 / 22 / 02$ & 0530 & variable & 2 \\
\hline & $3 / 5 / 02$ & 1500 & cont. & cont. & 106 & $>240$ \\
\hline \multirow[t]{4}{*}{ MG-76 } & cont. & cont. & $4 / 22 / 02$ & 0100 & 79 & -- \\
\hline & $2 / 22 / 02$ & 0700 & $2 / 22 / 02$ & 0900 & $79 ?$ & 2 \\
\hline & $2 / 23 / 02$ & 0700 & $2 / 23 / 02$ & $?$ & 79 & $<12$ \\
\hline & $2 / 25 / 02$ & 0700 & cont. & cont. & 79 & $>240$ \\
\hline
\end{tabular}

\footnotetext{
${ }^{1}$ Start and end times are approximate.
} 


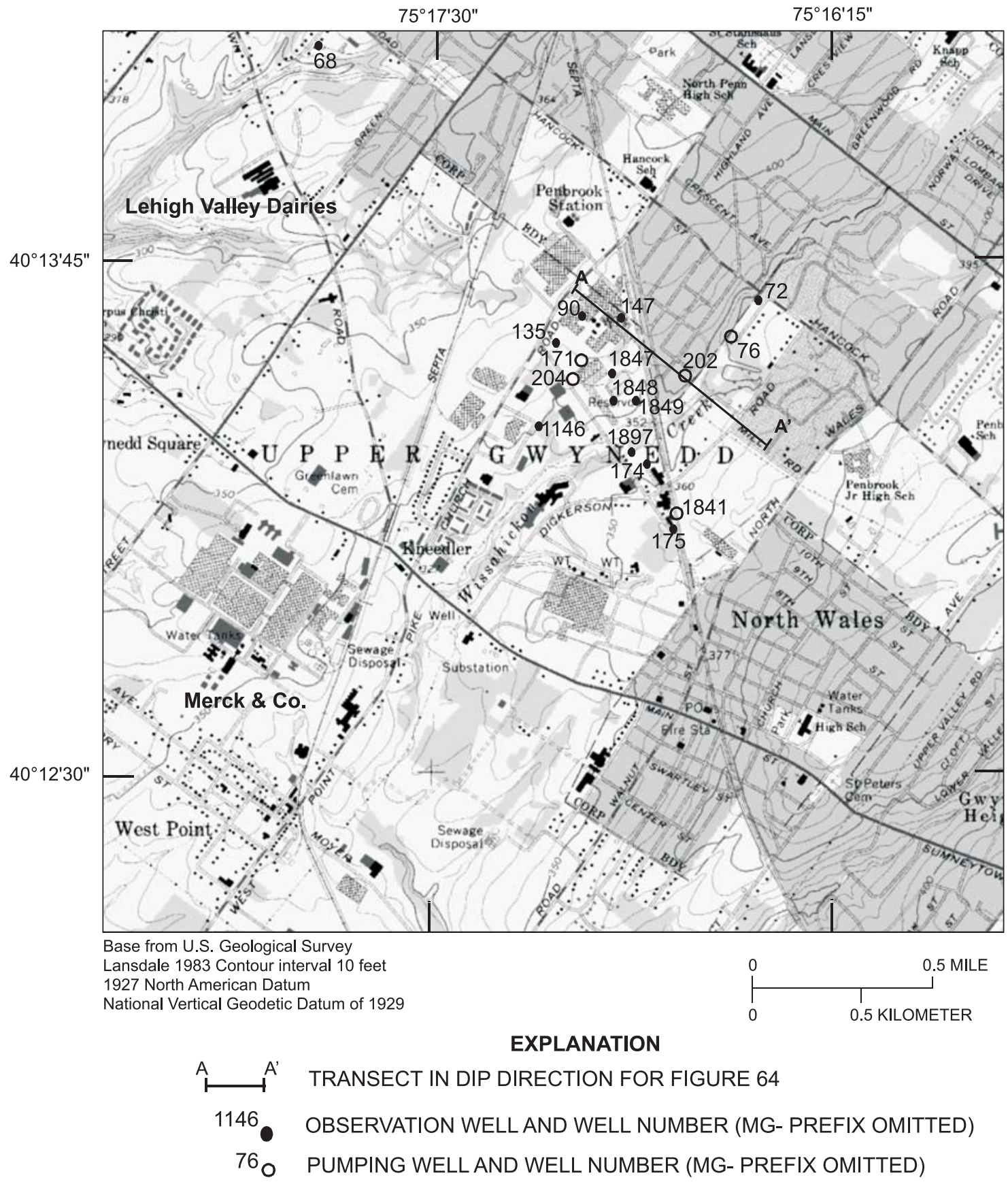

Figure 61. Location of wells with continuous water-level monitoring and pumping wells in the vicinity of North Penn Area 7 Superfund site, Upper Gwynedd Township, Montgomery County, Pa. Locations of individual pumping wells west of Church Road/West Point Pike at Merck \& Co., and Lehigh Valley Dairies are not shown. 
Water levels in three wells (MG-72, MG-174, and MG-1897) and one interval (Ford 4.4) in a well (MG-147) reconstructed as a well nest changed in response to the start and stop of pumping of wells MG-202 and MG-76 (fig. 62). The start of pumping well MG-202 on February 20 and March 5, 2002, is indicated by drawdowns in wells MG-72, MG-174, MG-1897, and interval Ford 4.4 of nested well MG-147. For the short pumping period on February 20, drawdowns ranged from about $0.4 \mathrm{ft}$ in well MG-1897 to about $3 \mathrm{ft}$ in interval Ford 4.4 of nested well MG-147. For the longer pumping period that started March 5, 2002, drawdowns ranged from about $4 \mathrm{ft}$ in well MG-1897 to more than $8 \mathrm{ft}$ in interval Ford 4.4 of nested well MG-147. The shutdown of well MG-76 during February $23-25,2002$, is reflected most strongly by the hydrograph of well MG-72, but smaller water-level rises associated with recovery can be seen in the hydrographs of the wells MG-174, MG-1897, and interval Ford 4.4 of nested well MG-147 (fig. 62).

Water levels in the other monitoring wells did not change in response to pumping but generally rose in response to precipitation on March 3 and 18, 2002 (figs. 62 and 63). The response to precipitation appears greatest in interval Ford 3.4 of the nested well MG-135 (fig. 63); however, the wellhead for this well nest is in a pit that fills with water following rainfall and the sharp rise in water levels may be caused by surface water entering the well. The water level in well MG-175 shows no response to pumping in wells MG-202 and MG-76 and little to no response to precipitation. However, the hydrograph for well MG-175 indicates water levels decline and rise slightly on a regular basis (fig. 63); this pattern appears to be associated with the intermittent but regular pumping of a nearby production well MG-1841 on the property.

The spatial pattern of drawdown may be related to geologic structure. Drawdowns related to the pumping of MG-202 are observed in wells that are open to the same interval as the major production zones of wells MG-202, with the exception of MG-175 and interval Ford 3.3 of nested well MG-135 in which water levels do not decline in response to pumping. Well MG-175 and interval Ford 3.3 are not open, however, to the thin plane projected from the major producing fractures at 159$160 \mathrm{ft}$ bls in well MG-202. A schematic cross-section drawn in the dip direction through the pumping well, assuming a dip direction of N. 50 degrees W. (strike direction of N. 40 degrees E.) and a dip angle of 7 degrees NW. shows all wells with observed drawdowns are in the dipping production zone (fig. 64), which may be associated with a specific mapped geologic unit (fig. 64). These wells include MG-174 in the updip direction, interval Ford 4.4 of nested well MG-147 in the down-dip direction, and wells MG-72 and MG-1897 in the strike direction. Boundaries of the lower Brunswick Group (geologic unit JTrb on fig. 3) are similar to the boundaries of this production zone.

Drawdowns in response to the start of pumping well MG-202 on March 5, 2002, are plotted as a function of time elapsed since pumping began for wells MG-72, MG-147 (Ford 4.4 interval), MG-174, and MG-1897 in figures 65 and 66. The drawdown data were analyzed for estimates of transmissivity (T) and storage coefficient (S) using the Theis (1935) solution for confined aquifers. The use of the Theis solution was based on a conceptual model that the dipping beds form layered confined aquifers and that the observation and pumping wells are in the same dipping aquifer. The early-time drawdown data are too linear to fit along the Theis solutions, indicating another solution may be more appropriate. The shape of the drawdown data indicate a solution for a leaky aquifer (Kruseman and de Ridder, 1990) may better fit the data, and if so, the estimates of $\mathrm{T}$ from the Theis solution will be too high. Estimates of T range from 773 to $1,625 \mathrm{ft}^{2} / \mathrm{d}$, and estimates of $\mathrm{S}$ range from 0.00003 to 0.0006 . These estimates of $\mathrm{T}$ and $\mathrm{S}$ are in the range of values reported from analysis of other aquifer tests in the area (Goode and Senior, 1998; Barton and others, 2003). Previous estimates (Goode and Senior, 1998) of T for isolated zones in wells on the former Ford property, including MG-147, ranged from about 44 to $380 \mathrm{ft}^{2} / \mathrm{d}$. 


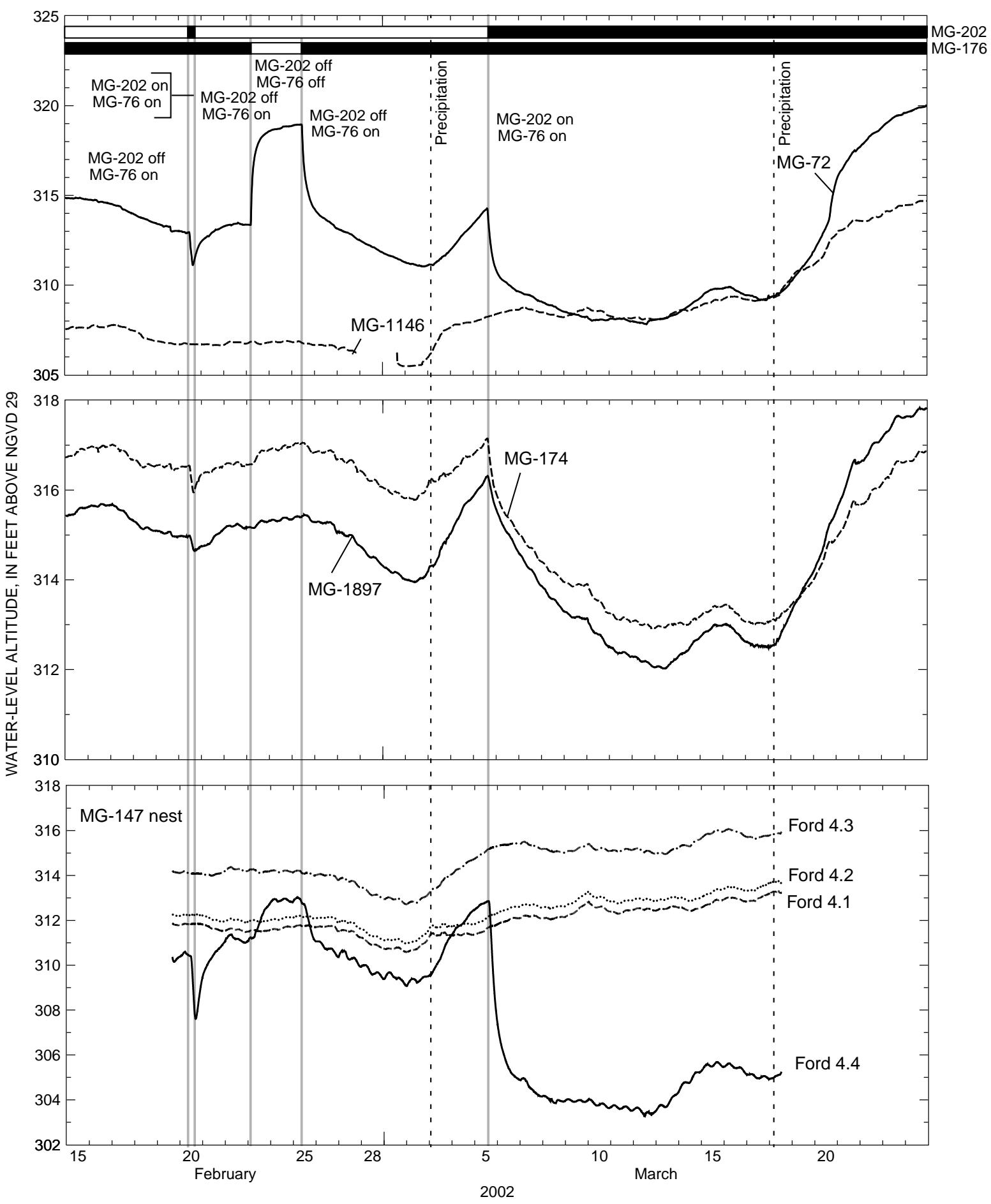

Figure 62. Altitude of water levels in observation wells MG-72, MG-1146, MG-174, MG-1897, and MG-147 (intervals Ford 4.1, 4.2, 4.3, and 4.4) in the vicinity of production wells MG-202 and MG-76, North Penn Area 7 Superfund site, Upper Gwynedd Township, Montgomery County, Pa., February-March 2002. Gaps indicate period of no data. Well MG-202 was pumped 8 hours on February 20, 2002, and continuously starting on March 5, 2002, while well MG-76 was pumped continuously except for a period during February 23-25, 2002, when the pump was shut down. At top of figure, black bar indicates period well was pumping. 


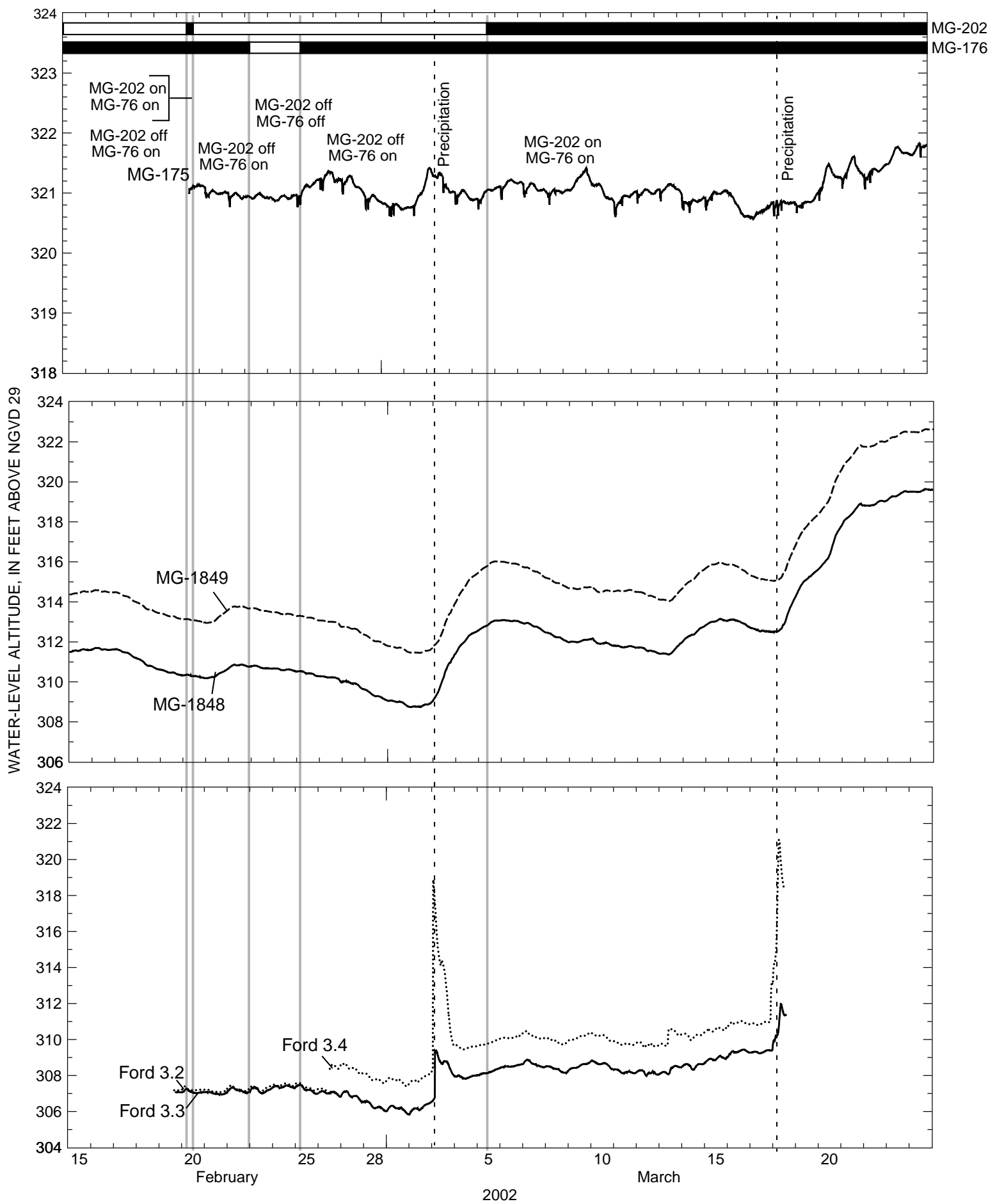

Figure 63. Altitude of water levels in observation wells MG-175, MG-1848, MG-1849, and MG-135 (intervals Ford 3.2, 3.3, and 3.4) in the vicinity of production wells MG-202 and MG-76, North Penn Area 7 Superfund site, Upper Gwynedd Township, Montgomery County, Pa., February-March 2002. Gaps indicate period of no data. Well MG-202 was pumped 8 hours on February 20, 2002, and continuously starting on March 5, 2002, while well MG-76 was pumped continuously except for a period during February 23-25, 2002, when the pump was shut down. At top of figure, black bar indicates period well was pumping. 


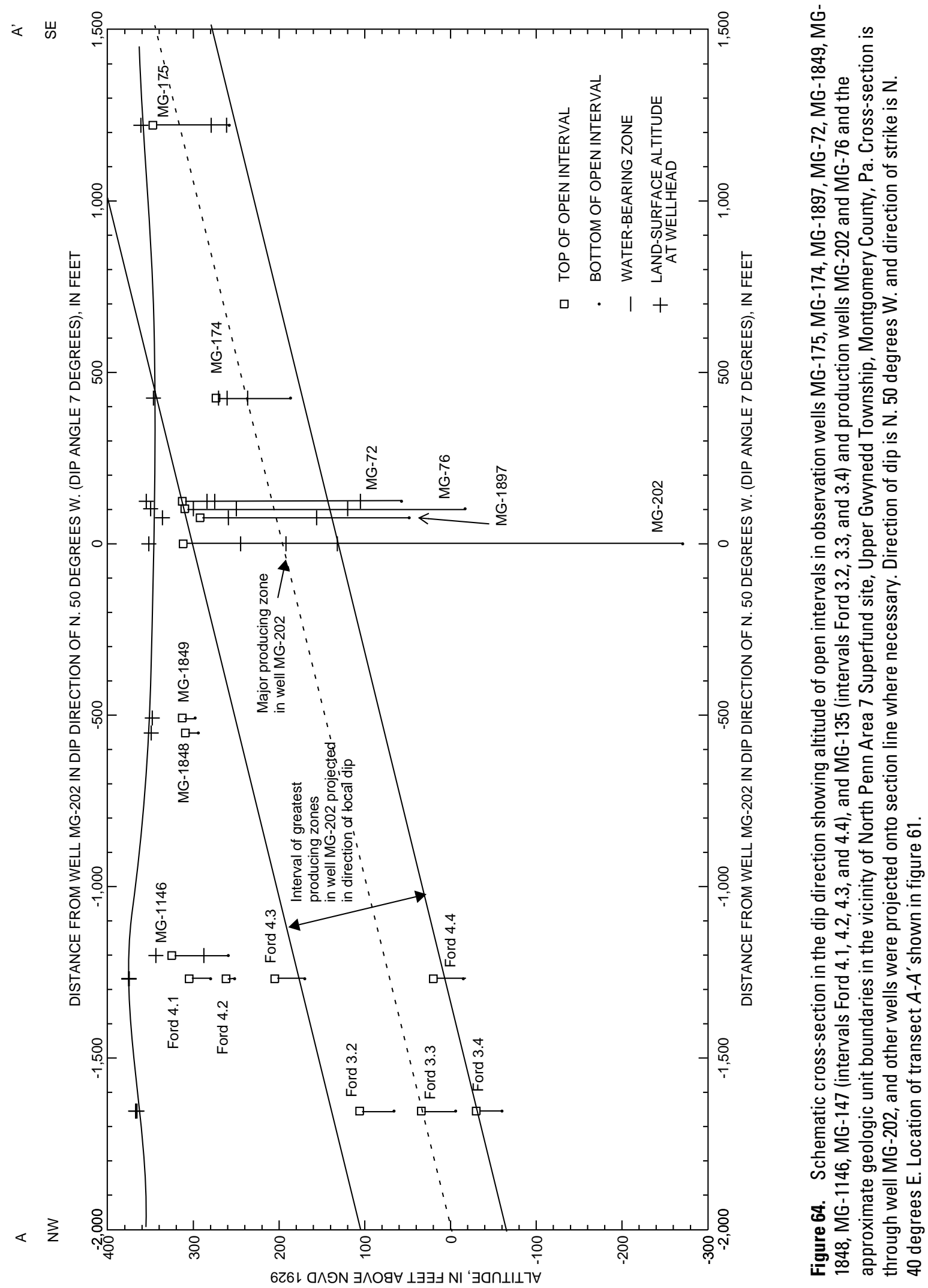



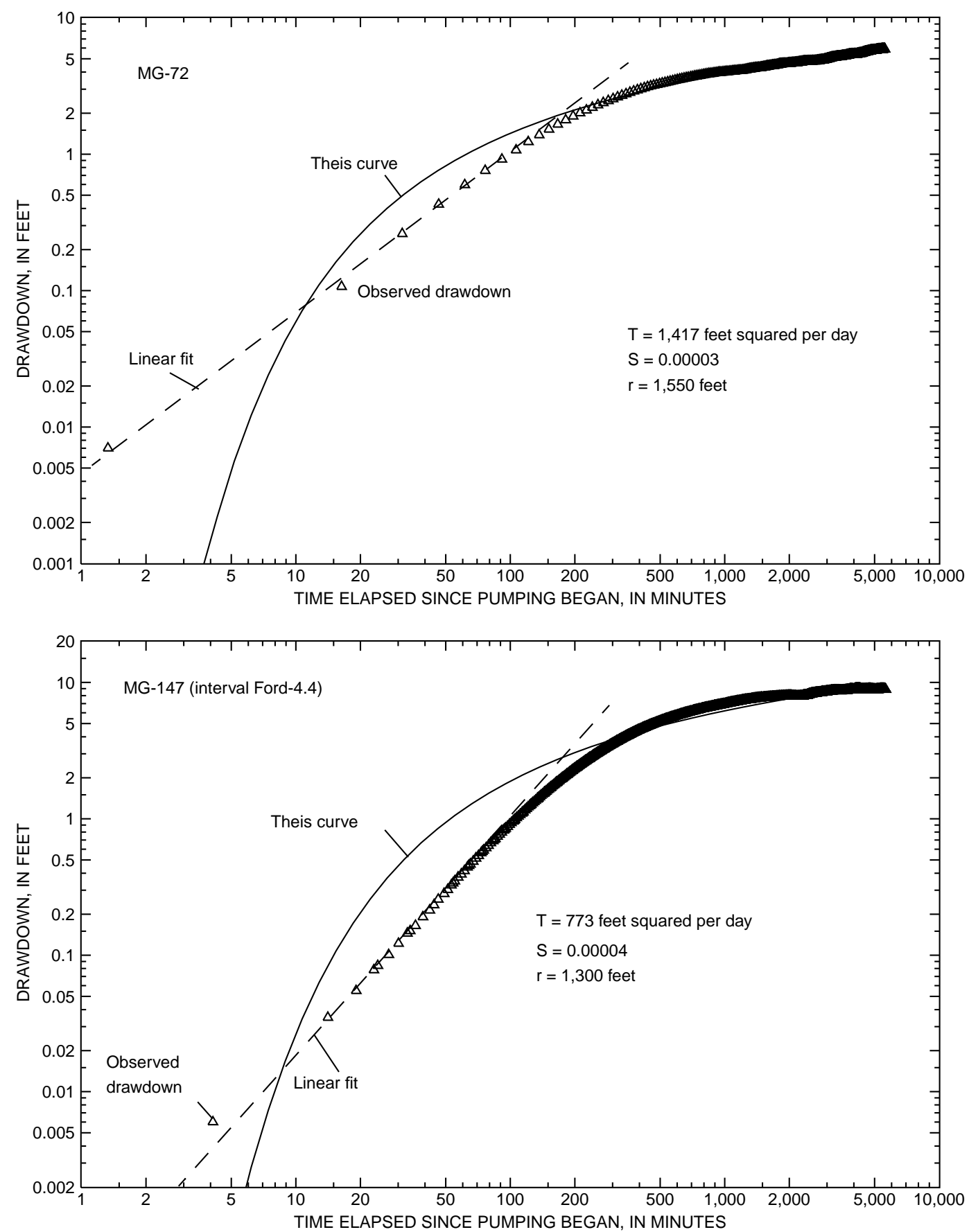

Figure 65. Drawdown in observation wells MG-72 and MG-147 (Ford 4.4) in response to the start of pumping of production well MG-202 in the vicinity of North Penn Area 7 Superfund site, Upper Gwynedd Township, Montgomery County, Pa., on March 5, 2002, at a rate of 106 gallons per minute. Observed drawdown data are shown with Theis curves fitted for late-time data and resulting estimates of transmissivity (T) and storage coefficient (S) for observation wells at radial distances ( $r$ ) from pumping well. 

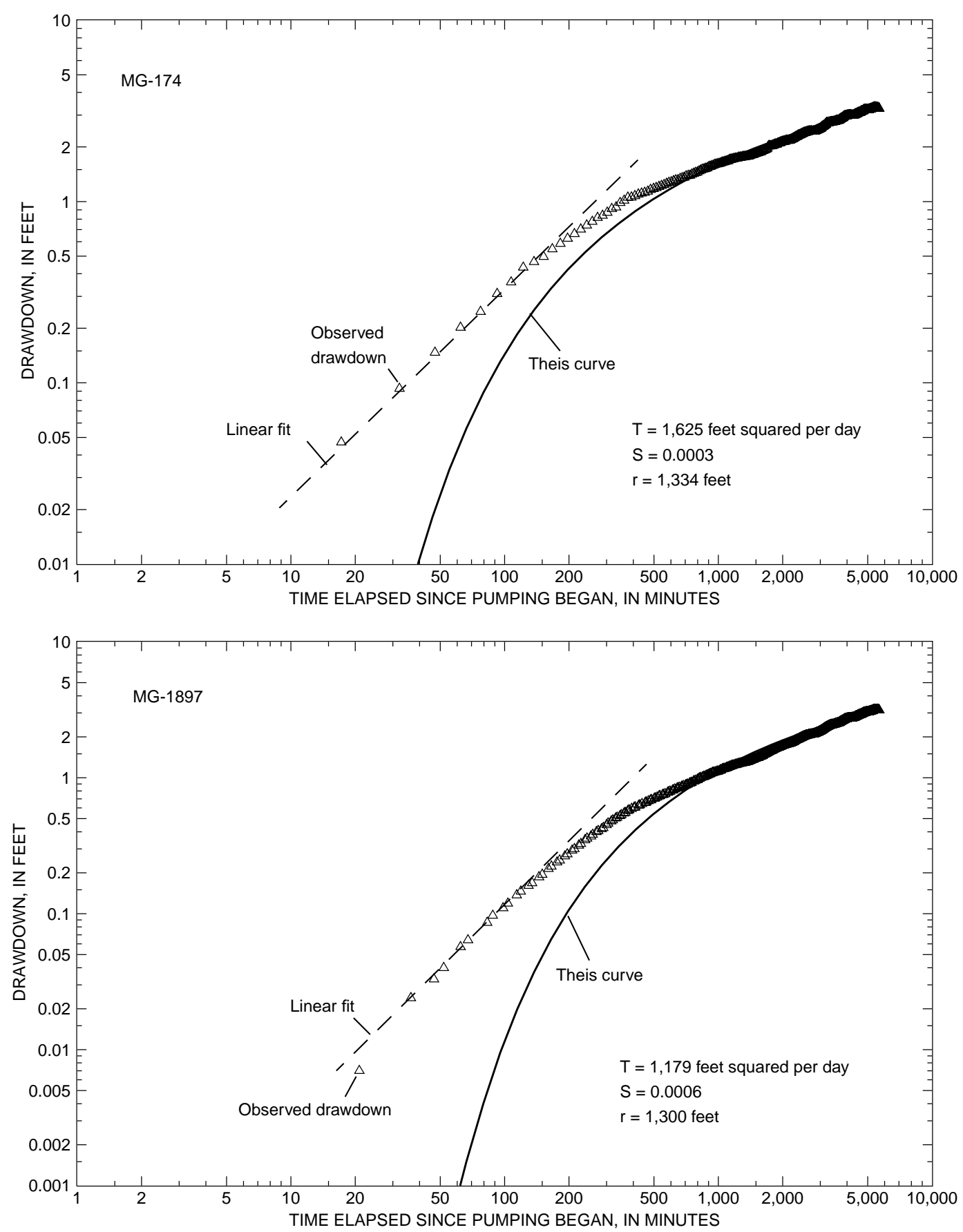

Figure 66. Drawdown in observation wells MG-174 and MG-1897 in response to the start of pumping of production well MG-202 in the vicinity of North Penn Area 7 Superfund site, Upper Gwynedd Township, Montgomery County, Pa., on March 5, 2002, at a rate of 106 gallons per minute. Observed drawdown data are shown with Theis curves fitted for late-time data and resulting estimates of transmissivity $(\mathrm{T})$ and storage coefficient $(\mathrm{S})$ for observation wells at radial distances $(r)$ from pumping well. 


\section{Water Levels}

Water levels measured in wells in an unconfined aquifer indicate the level of the water table. In confined aquifers, water levels measured in wells indicate the level of a potentiometric surface. In the fractured-sedimentary-rock aquifers underlying North Penn Area 7 and vicinity, water-bearing fractures in wells constructed as open holes typically have different potentiometric heads, and, therefore, water levels measured in wells constructed as open holes that intersect one or more waterbearing fractures represent composite heads. Water levels typically are measured as the depth to water from land surface and are expressed as the altitude of the water level above the National Geodetic Vertical Datum of 1929. The altitude of the water table or potentiometric surface indicates potential energy (head). In pumped or recently pumped wells, observed water levels may be depressed by drawdown (including well loss) or slow recovery and do not necessarily reflect nearby water levels in the aquifer.

\section{Fluctuations}

Seasonal processes, precipitation events, and changes in pumping cause water-level fluctuations. Water levels rise in response to recharge to the ground-water system from precipitation and decline in response to discharge from the groundwater system to ground-water evapotranspiration, streams, and pumping. In southeastern Pennsylvania, where precipitation is distributed nearly evenly year-round, water levels generally rise during the late fall, winter, and early spring when soil moisture and ground-water evapotranspiration are at a minimum and recharge is at a maximum. The depth to water is least in the late winter and early spring when water levels rise because rates of recharge are greater than rates of discharge. Water levels generally decline during the late spring, summer, and early fall when soil moisture and ground-water evapotranspiration are at a maximum and recharge is at a minimum. The magnitude of seasonal fluctuations or shorter-term changes in water levels in response to recharge is related to aquifer porosity and storage. Following recharge, the rise in water levels may be greater and sustained longer in aquifers with low permeability and (or) storage than in aquifers with high permeability and (or) storage.

Water levels were measured continuously from December 2000 through September 2002 in three wells (MG-68, MG-72, and MG-1146; fig. 67) in and near North Penn Area 7. The wells were constructed as open holes, ranged in depth from about 85 to $460 \mathrm{ft}$, were cased from 9 to $41.5 \mathrm{ft}$ below land surface, and had multiple water-bearing zones (table 63). Fluctuations in the depth to water (fig. 67) were greater for the two wells (MG-72 and MG-1146) near Wissahickon Creek than in the well to the northwest of North Penn Area 7 (MG-68) near the headwaters of Towamencin Creek. Water levels in well MG-72 are affected by pumping in nearby production wells along Wissahickon Creek. Despite differences in well depths, distances from the stream, and proximity to pumping production wells, water levels in well MG-1146 are similar to those measured in well MG-72, except for a period of November and December 2001 when water levels in MG-72 were 10 to $15 \mathrm{ft}$ deeper than water levels in MG-1146. Water levels in well MG-68 probably are not affected to a large degree by local pumping and approximate background conditions in the area. Factors other than pumping that may affect long-term fluctuations in water levels are spatial variability in recharge rates or storage characteristics of the aquifer.

Table 63. Well depth, casing length, well diameter, depth of water-bearing zones, and proximity to a stream for wells with continuous water-level monitoring in the vicinity of North Penn Area 7 Superfund site, Upper Gwynedd Township, Montgomery County, $\mathrm{Pa}$.

[ft bls, feet below land surface; ft, feet; in., inches; >, greater than]

\begin{tabular}{lccccc}
\hline $\begin{array}{c}\text { U.S. } \\
\text { Geological } \\
\text { Survey }\end{array}$ & $\begin{array}{c}\text { Well } \\
\text { depth } \\
\text { (ft bls) }\end{array}$ & $\begin{array}{c}\text { Casing } \\
\text { length } \\
\text { (ft) }\end{array}$ & $\begin{array}{c}\text { Well } \\
\text { diameter } \\
\text { (in.) } \\
\text { number }\end{array}$ & $\begin{array}{c}\text { 1'Depth } \\
\text { of water- } \\
\text { bearing } \\
\text { zones } \\
\text { (ft bls) }\end{array}$ & $\begin{array}{c}\text { Within } \\
\mathbf{2 0 0} \mathbf{f t} \\
\text { of } \\
\text { stream }\end{array}$ \\
\hline MG-68 & 500 & 9 & 214 & 110,171, & yes \\
& & & & $\begin{array}{c}323,371, \\
>426\end{array}$ & \\
MG-72 & 298 & 41.5 & 10 & $71,86,250$ & yes \\
MG-1146 & 84.5 & 18.5 & 6 & 58,84 & no \\
\hline
\end{tabular}

${ }^{1}$ Greatest depth reported for water-bearing zone as inferred from geophysical logs; zones typically less than $10 \mathrm{ft}$ in thickness.

${ }^{2}$ Borehole diameter decreases to $10 \mathrm{in}$. at $50 \mathrm{ft}$ bls and to $8 \mathrm{in}$. at $250 \mathrm{ft}$ bls.

In wells not affected by nearby pumping, rising water levels indicate periods of recharge. The response of water levels to recharge by precipitation and decreased evapotranspiration is shown for well MG-68 for the period of December 2000 through September 2002 on figure 67. Recharge is indicated by rising water levels in all three wells monitored during winter and spring of 2001 and spring of 2002. In southeastern Pennsylvania, the autumn of 2001 through winter of 2002 and summer of 2002 were drought periods and water levels declined sharply during these periods. Annual precipitation measured at Conshohocken, Pa., a weather station about $10 \mathrm{mi}$ south of North Wales (fig. 2), was about 51.09 in. in 2000 and 36.05 in. in 2001. Compared to the normal annual precipitation of 48.79 in. at Conshohocken computed for the 30-year period, 1971-2000, annual precipitation was about 2.3 in. (4.7 percent) above normal in year 2000 and 12.74 in. (26 percent) below normal in year 2001 (National Oceanic and Atmospheric Administration 2000; 2001; 2002a). For the first 9 months of year 2002 through September 30, precipitation was from 19 to 26 percent below normal at two nearby meteorological stations, Graterford $1 \mathrm{E}$ and Neshaminy Falls (table 64). 


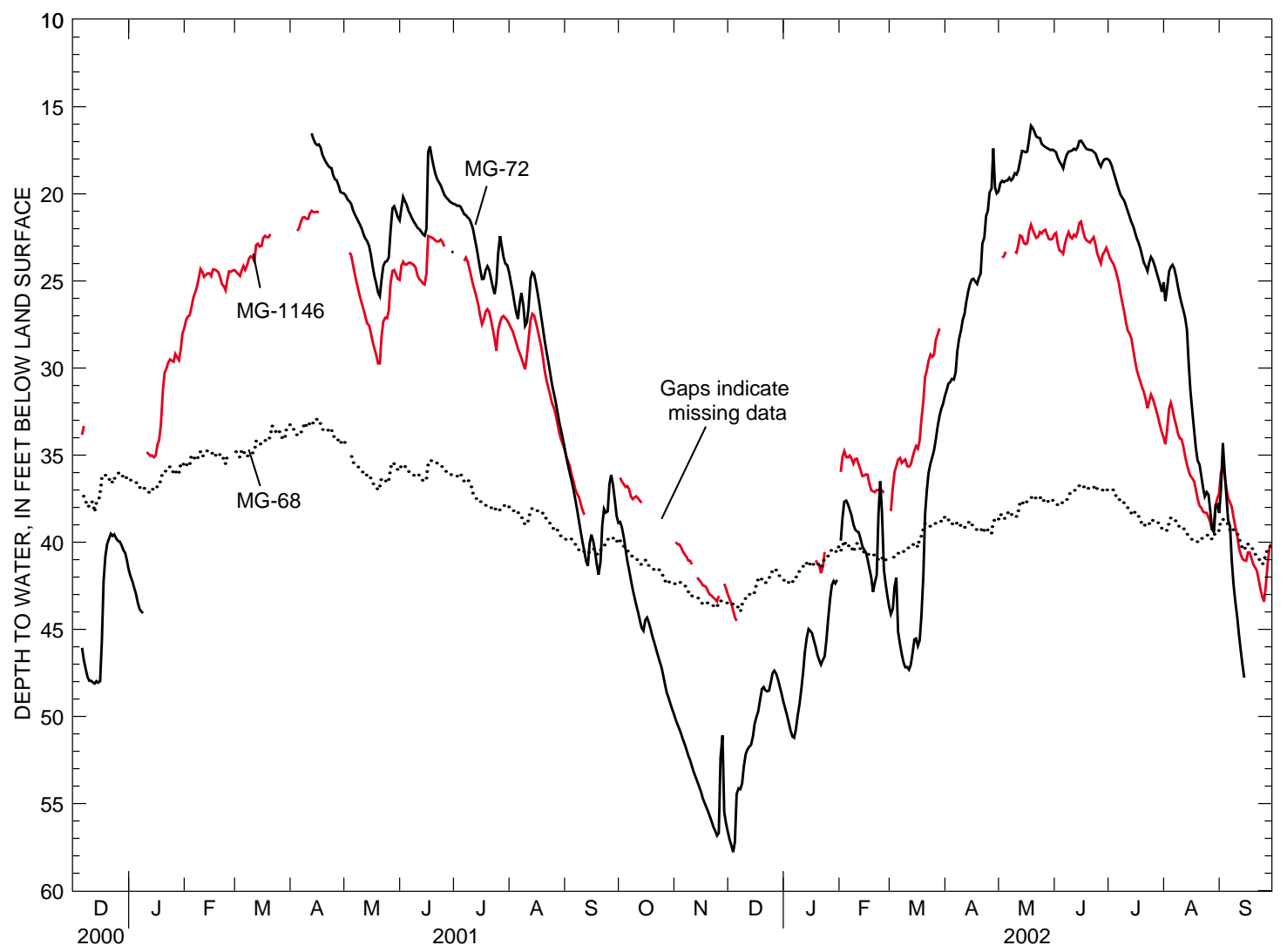

Figure 67. Daily mean depth to water in wells MG-68, MG-72, and MG-1146, December 2000 through September 2002, North Penn Area 7 Superfund site, Upper Gwynedd Township, Montgomery County, Pa. Records for MG-72 and MG-1146 are missing data for periods of 1 month or more.

Table 64. Annual precipitation in inches for 2000-02 and 30-year normal precipitation at four meteorological stations near North Penn Area 7 Superfund site in Bucks and Montgomery Counties, southeastern Pa. Location of meteorological stations shown on figure 2 .

[M, 1-9 days of missing data in record; --, no data]

\begin{tabular}{|c|c|c|c|c|c|}
\hline \multirow[b]{2}{*}{ Station } & \multirow[b]{2}{*}{ County } & \multicolumn{4}{|c|}{ Annual precipitation (and departure from normal), in inches } \\
\hline & & 2000 & 2001 & $2002^{1}$ & $\begin{array}{c}1971-2000 \\
\text { normal }\end{array}$ \\
\hline Bucksville & Bucks & $46.56 \mathrm{M}(-3.19)$ & $43.22 \mathrm{M}(-6.78)$ & -- & 49.75 \\
\hline Sellersville & Bucks & $46.40 \mathrm{M}$ & 39.76 & 29.26 & $--^{2}$ \\
\hline Conshohocken & Montgomery & $51.09 \mathrm{M}(2.30)$ & $36.05(-12.74)$ & -- & 48.79 \\
\hline Graterford $1 \mathrm{E}$ & Montgomery & $44.55 \mathrm{M}(0.20)$ & -- & $27.92(-6.4)$ & 44.35 \\
\hline Neshaminy Falls & Bucks & $50.78 \mathrm{M}(0.54)$ & $40.25 \mathrm{M}(-9.99)$ & $28.38(-10.03)$ & 50.24 \\
\hline
\end{tabular}

${ }^{1}$ From January 1 through September 30, 2002.

${ }^{2}$ No data for 30-year normal because period of record started in 1995. 
The short-term (5-10 days or less) response to precipitation for two wells is shown in figure 68 for a 2 -week period in March 2002. The precipitation data are for the nearest National Oceanic and Atmospheric Administration (NOAA) meteorological station Graterford $1 \mathrm{E}$ (National Oceanic and Atmospheric Administration, 2002b), about 6 mi southwest of North Penn Area 7 (fig. 2). In most wells monitored in the vicinity of North Penn Area 7, the response was rapid (within 4-8 hours of rainfall), indicating the rise in water levels probably was caused by an increase in hydrostatic pressure rather than physical infiltration of water. The rapid response of water levels to precipitation indicates these wells penetrate confined parts of the aquifer. The timing of the rise in water levels in the two wells in response to precipitation was similar but the magnitude of response differs. In response to rainfall from March 18 through March 21, 2002, water levels rose about $2.5 \mathrm{ft}$ in well MG-68 and more than $5 \mathrm{ft}$ in well MG-1146 (fig. 68).

\section{Relation to Streamflow}

Streams will gain water from ground-water discharge when the potentiometric head (water level) in the aquifer near the stream is greater than the altitude of the stream. Conversely, streams will lose water to the aquifer when the potentiometric head in the aquifer near the stream is less than the altitude of the stream. Some streams in the region may be supplied in part from ground water discharged from a shallow perched aquifer. The Wissahickon Creek flows intermittently and is dry much of the year during periods of low precipitation. Ground-water levels near Wissahickon Creek in the vicinity of North Penn Area 7 were lower than the altitude of
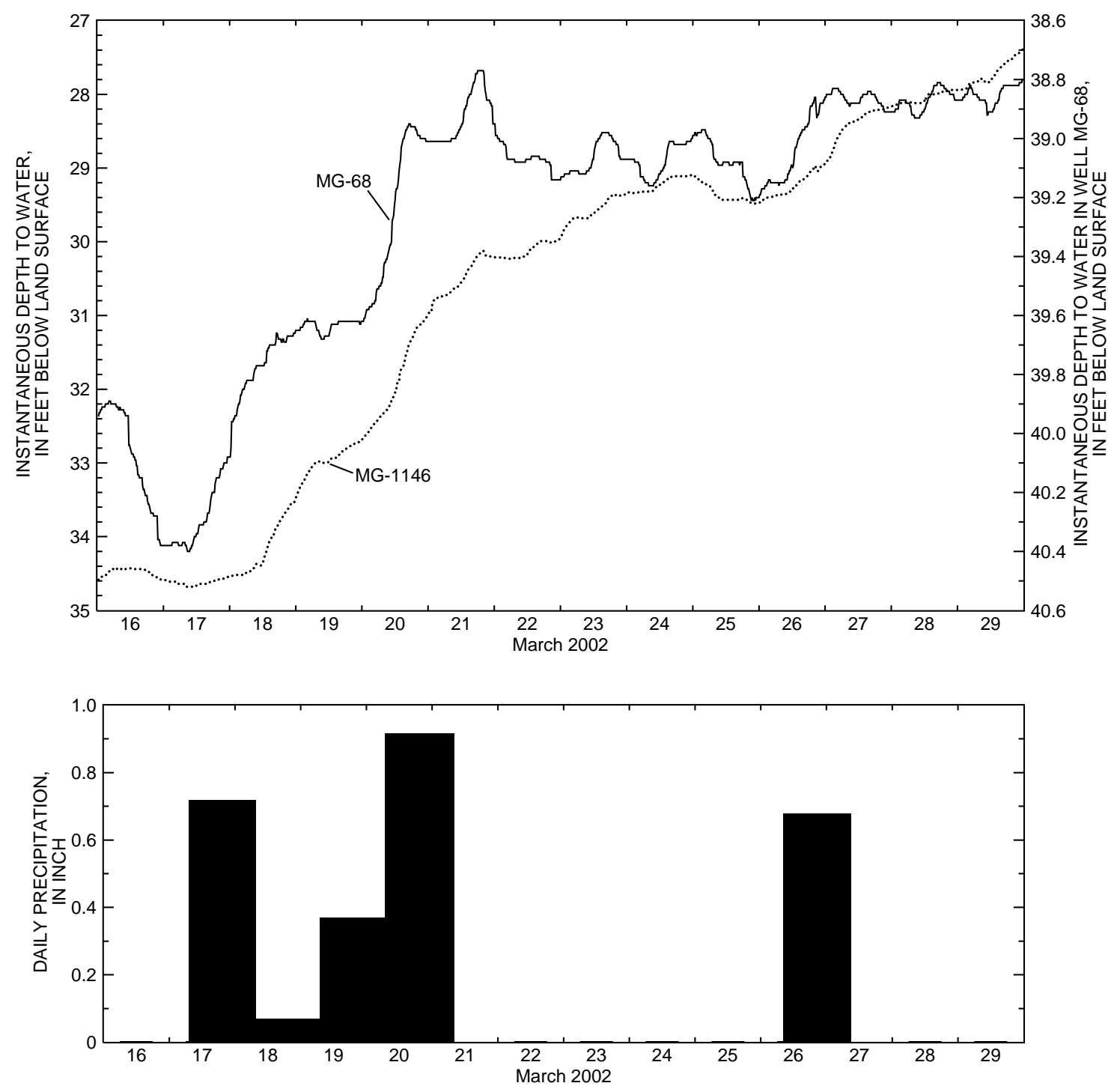

Figure 68. Instantaneous depth to water in wells MG-68 and MG-1146 and daily precipitation at the Graterford 1 E meteorological station, March 16 through March 29, 2002, in the vicinity of North Penn Area 7 Superfund site, Upper Gwynedd Township and Lansdale, Montgomery County, Pa. 
the stream channel for much of the period from December 2000 through September 2002. These ground-water-level conditions indicate Wissahickon Creek is a losing stream during this time. These losing conditions probably are largely the result of nearby pumping. Simulation of ground-water flow in the area (Senior and Goode, 1999) indicated that ground water discharges to Wissahickon Creek under conditions of no pumping.

Base flow was measured quarterly at two sites on Wissahickon Creek from December 2000 through September 2002 (table 65). The altitude of the stream-channel bottom is about $328 \mathrm{ft}$ above NGVD 29 at streamflow-measurement site 01473808 Wissahickon Creek at North Wales, Pa., and $312 \mathrm{ft}$ above NGVD 29 at streamflow-gaging site 01473809 Wissahickon Creek at Kneedler, Pa., which is about 0.6 mi. downstream (fig. 69). Stream losses to ground water are indicated by the smaller amount of streamflow measured at the downstream site, 01473809 , compared to the upstream site for all measurements except March 2001.

Table 65. Quarterly measurements of streamflow under baseflow conditions for streamflow-measurement site 01473808 , Wissahickon Creek at North Wales, Pa., and 01473809, Wissahickon Creek at Kneedler, Pa., and daily mean altitude of water levels in wells MG-72 and MG-1146, Montgomery County, Pa., December 2000 through September 2002.

[NGVD 29, National Geodetic Vertical Datum of 1929; --, no data]

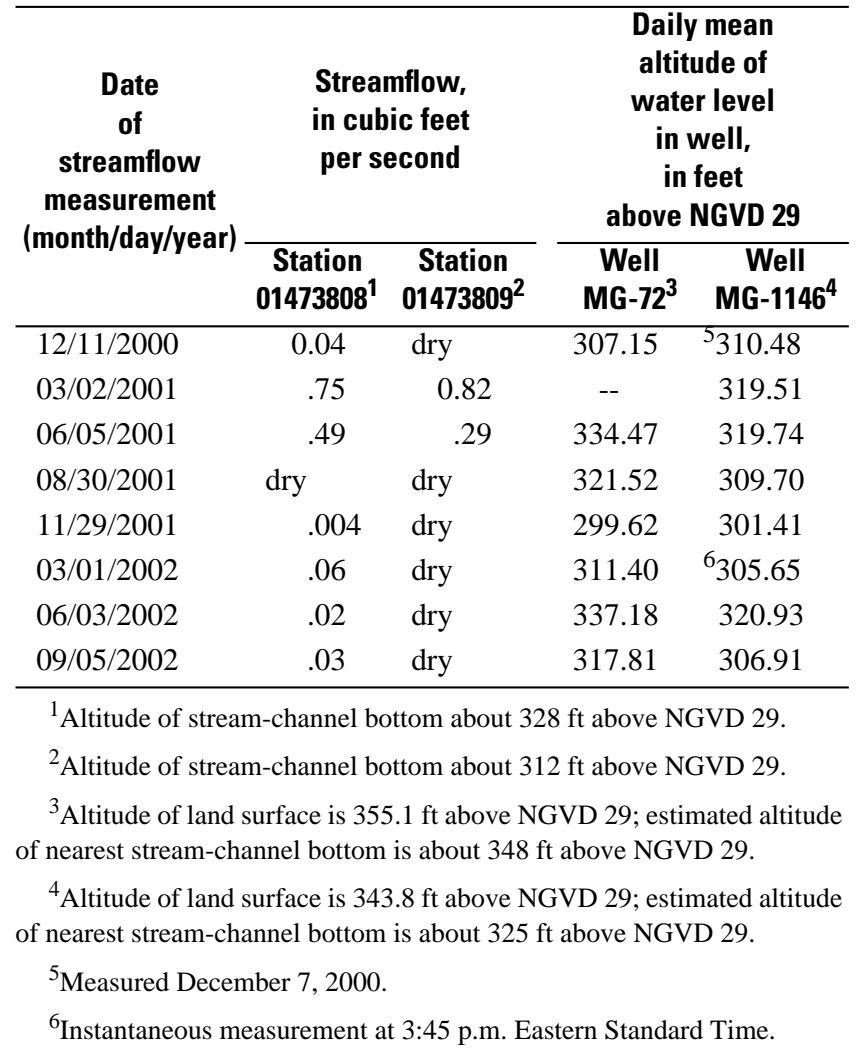

Water-level data from wells MG-72 and MG-1146 (table 65) indicate that ground-water levels are lower than the Wissahickon Creek channel bottom at nearby stream locations for all quarterly base-flow measurements. Well MG-72 is near Wissahickon Creek about 0.5 mi upstream of site 01473808. The altitude of the stream-channel bottom adjacent to well MG-72 is about $348 \mathrm{ft}$ above NGVD. Well MG-1146, about $0.1 \mathrm{mi}$ northwest of site 01473808 , is closer to site 01473808 than the downstream site 01473809 . The lower altitude of the ground-water levels in relation to the altitude of the stream channel bottom implies that the Wissahickon Creek has potential to lose water to the ground-water system during the period of data collection from December 2000 through September 2002 (fig. 70). Supporting these relations between ground water and surface water are measurements at two sites on Wissahickon Creek. Streamflow at the downstream site 01473809 is less than or equal to streamflow at the upstream site 01473808 for all measurements except the March 2001 measurement, which indicated gaining conditions. Although ground-water levels were relatively high during February 2001, a runoff event (snowfall followed by melting) occurred on February 26 [as indicated by record at the downstream streamflow-measurement site, 01473900 Wissahickon Creek at Fort Washington (Durlin and Schaffstall, 2002)] prior to the March 2, 2001, base-flow measurements. The apparent gain may be related to discharge from a perched aquifer or interflow from the February 26 storm because ground-water levels were not high enough to allow discharge from the bedrock (fractured-sedimentary-rock) aquifer to this reach.

Although the reach of the Wissahickon Creek that bisects North Penn Area 7 loses water to the ground-water system, changes in ground-water levels in North Penn Area 7 mirror changes in base flow farther downstream, indicating gaining reaches elsewhere. Relations between ground-water levels and streamflow at a continuous-record streamflow-measurement site, 01473900 Wissahickon Creek at Fort Washington, Pa., which is about $5 \mathrm{mi}$ downstream from North Penn Area 7, are shown in fig 71. During the period from December through September 2002, base flow as determined by streamflow-separation techniques using the local minimum method (Sloto and Crouse, 1996), a technique that provides the most conservative base-flow values, at the streamflow-measurement site 01473900 was highest in February, March, and April 2001. Based on altitudes of ground-water levels nearby, most measured flow in the reach of Wissahickon Creek near wells MG-72 and MG-1146 probably is derived from surface runoff, discharge from saturated soils and perhaps a shallow perched aquifer in the saprolite, and upstream contributions from the ground-water system rather than local discharge from the bedrock aquifer. 


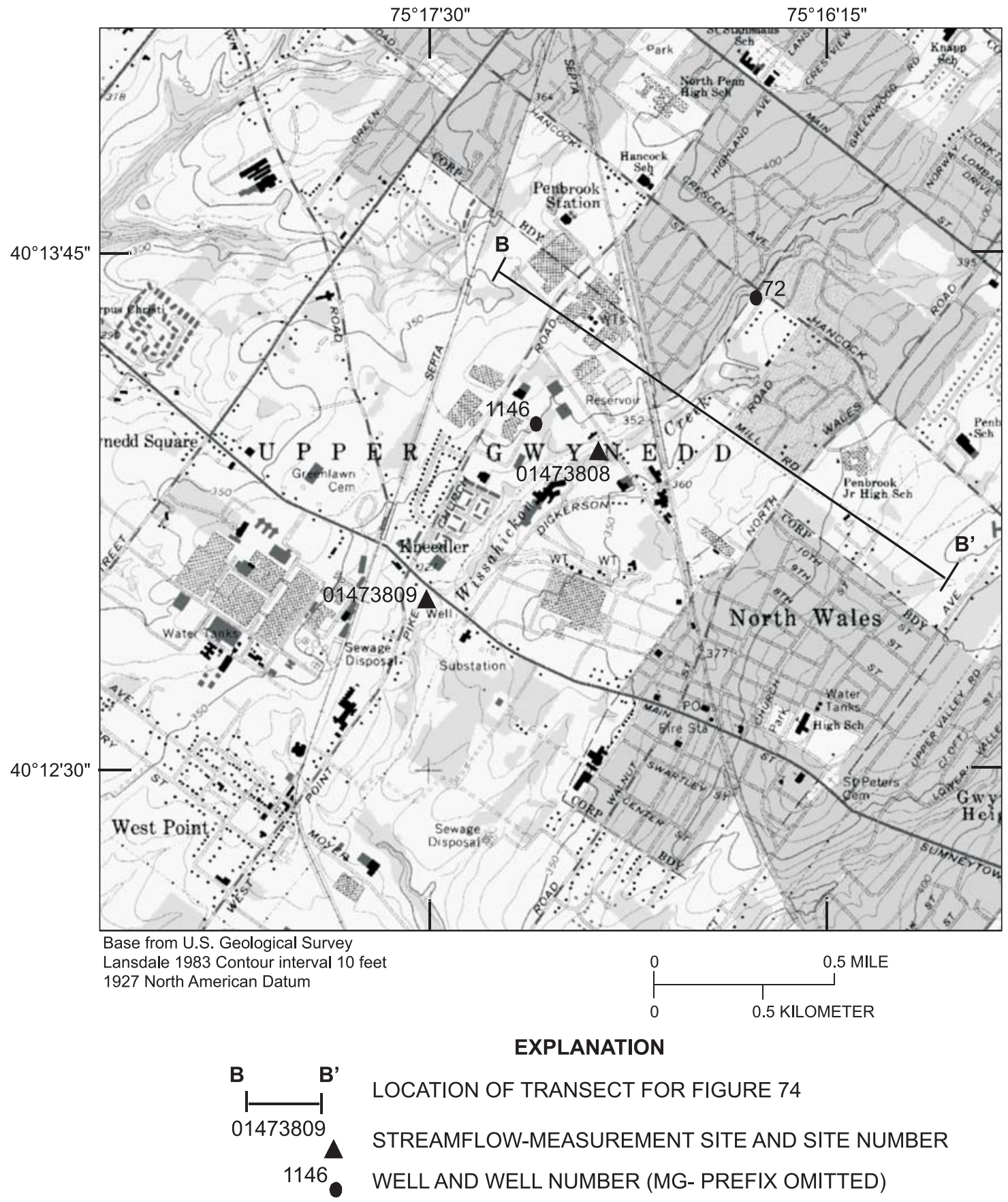

Figure 69. Location of two streamflow-measurement sites with quarterly measurements and two wells with continuous water-level monitoring, North Penn Area 7 Superfund site, Upper Gwynedd Township, Montgomery County, $\mathrm{Pa}$. 


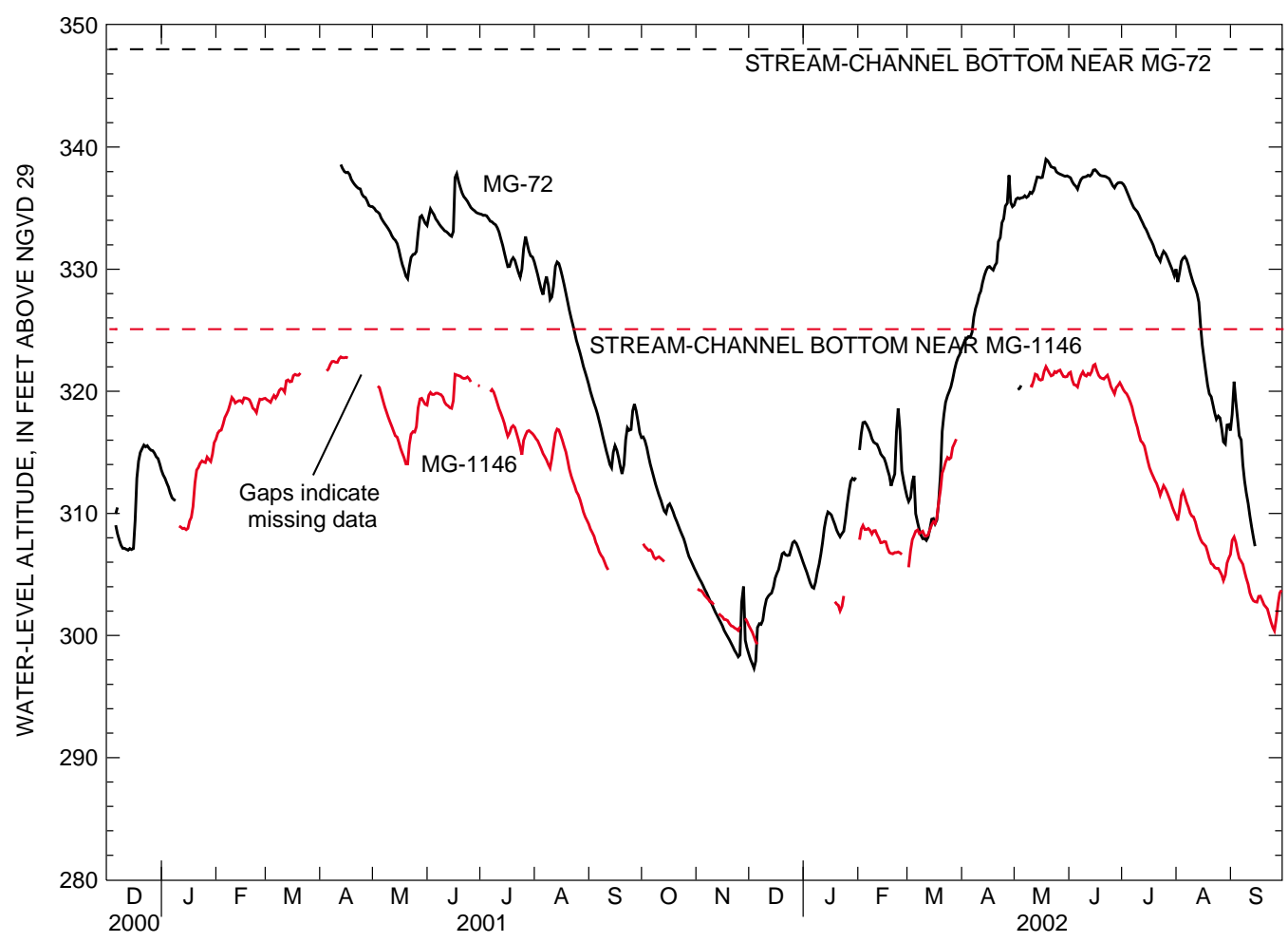

Figure 70. Hydrographs showing altitude of water levels in wells MG-72 and MG-1146 and estimated altitudes of stream-channel bottoms nearby, North Penn Area 7 Superfund site, Upper Gwynedd Township, Montgomery County, Pa., December 2000 through September 2002.

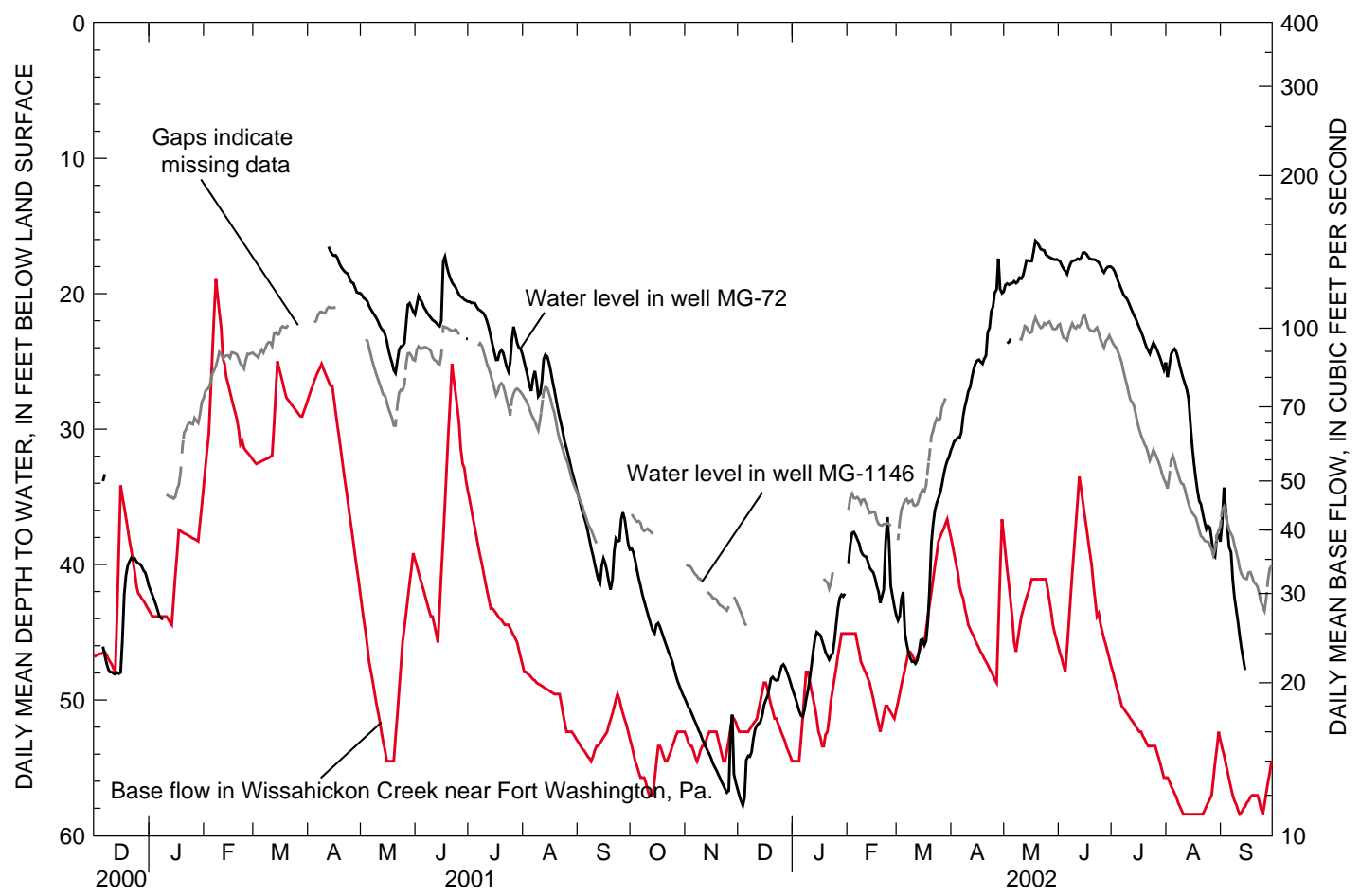

Figure 71. Relations between base flow at streamflow-measurement site 01473900, Wissahickon Creek at Fort Washington, $\mathrm{Pa}$., and water levels in wells MG-72 and MG-1146 near North Penn Area 7 Superfund site, Upper Gwynedd Township, Montgomery County, Pa., December 2000 through September 2002. 


\section{Regional Potentiometric Surface}

Water levels in about a $16-\mathrm{mi}^{2}$ area including and surrounding North Penn Area 7 were measured during a short, 3day period (December 4-6, 2000) to provide information for estimating the regional potentiometric surface at that time. Based on records of long-term observation wells in similar geologic settings in southeastern Pennsylvania (BK-929 and BK-1020, fig. 2), ground-water levels on December 5, 2000, were within $0.8 \mathrm{ft}$ of long-term averages for early December and about $2 \mathrm{ft}$ lower than the long-term average annual water level (fig. 72). For example, water levels in observation well BK-929, which has a 20-year record and is open to the same geologic formation (Brunswick Group) underlying much of North Penn Area 7 but about 14 mi north, were similar to the long-term annual mean water level in early December 2000 (fig. 72). In the region, lowest annual water levels typically occur in September or October, highest annual water levels occur in April or May, and average annual water levels occur in January and July.

A map of water levels measured December 4-6, 2000 (fig. 73; Senior and Ruddy, 2004) shows the altitudes of water levels are highest on the ridges underlain by the Lockatong Formation that straddle the Wissahickon Creek and lowest in the cone of depression caused by pumping at Merck and Towamencin Creek to the southwest. The contoured map represents only changes in water level altitudes in the horizontal direction. Although the contoured water levels in the semi-confined aquifer beneath North Penn Area 7 do not represent the water table, the surface is nevertheless similar to topography. The contoured water-level altitudes differ from topography in the areas affected by relatively large amounts of pumping. Ground-water divides between the Wissahickon Creek Basin and the adjacent basins appear to be coincident with the topographic divides on the ridges underlain by the Lockatong Formation. However, in the area affected by industrial pumping at Merck, the groundwater divides are at the edges of the cone of depression. The map of water levels measured in December 2000 confirms the general configuration of the potentiometric surface of the fractured-sedimentary-rock aquifer depicted in the overlapping area of a map based on water levels measured in August 1996 (Senior and others, 1998).

Because ground water flows from higher to lower head (water level), the general direction of ground-water flow can be estimated from a map of the water table or potentiometric surface. If no vertical head differences are present, then flow is planar (two-dimensional). In isotropic aquifers, the direction of flow is perpendicular to hydraulic gradient but in anisotropic aquifers, the direction of flow is not exactly perpendicular to the hydraulic gradient. The map of water levels in December 2000 indicates that ground water in the fractured-sedimentaryrock aquifer flows from the ridges underlain by the Lockatong

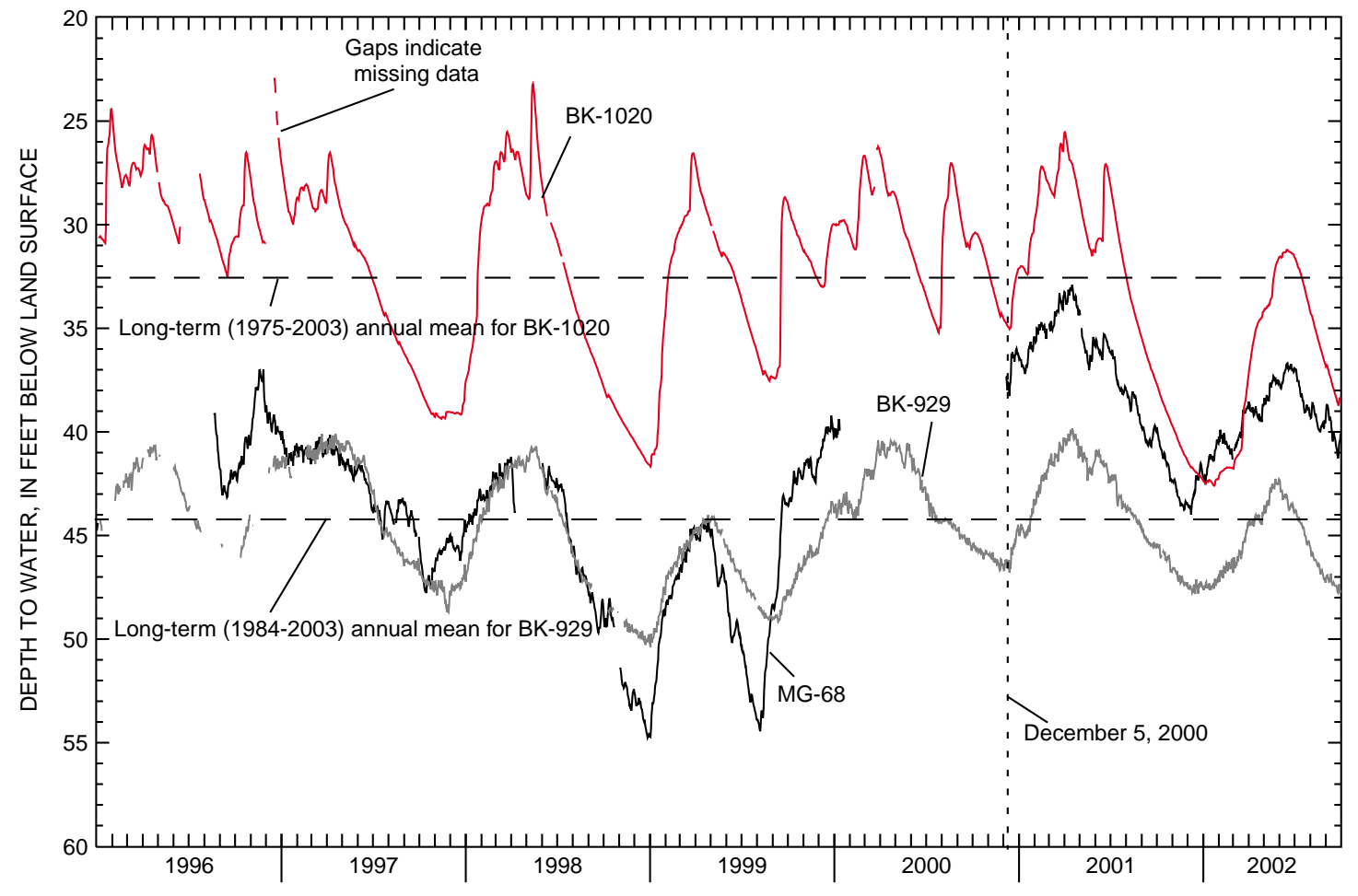

Figure 72. Daily mean water levels in long-term observation wells BK-1020 and BK-929 and in well MG-68 near North Penn Area 7 Superfund site, Upper Gwynedd Township, Montgomery County, Pa., January 1996 through September 2002. 


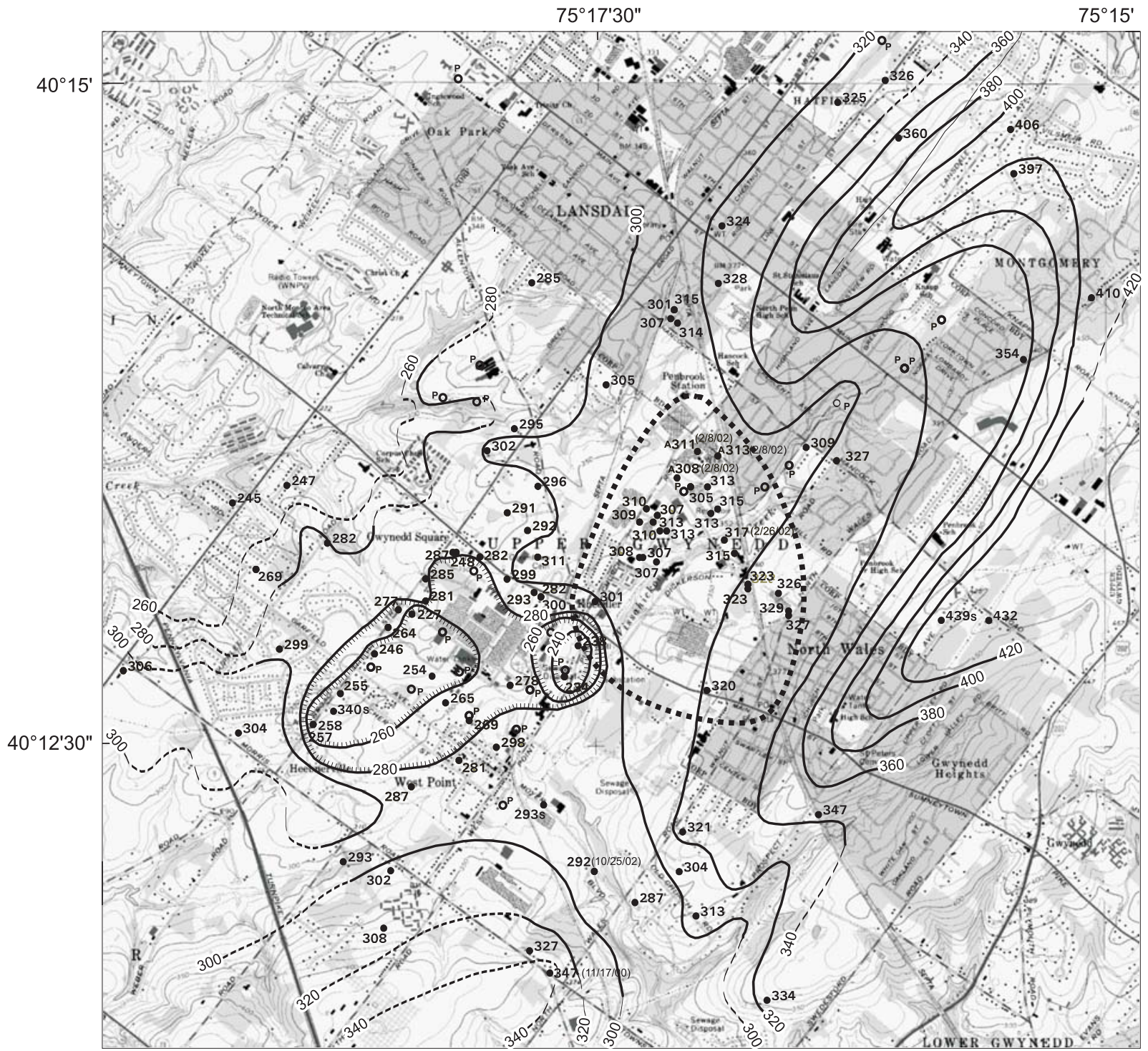

Base from U.S. Geological Survey

Lansdale 1:24,000, 1983 Contour Interval 10 feet Ambler 1:24,000, 1983 Contour Interval 10 feet Telford 1:24,000, 1980 Contour interval 20 feet Doylestown 1:24,000, 1983 Contour interval 20 feet 1927 North American Datum

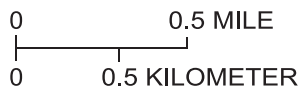

\section{EXPLANATION}

300 POTENTIOMETRIC CONTOUR ESTIMATED FROM WATER LEVELS MEASURED IN DRILLED WELLS. CONTOUR INTERVAL 20 FEET; HACHURED CONTOUR INDICATES DEPRESSION

321 LOCATION AND ALTITUDE OF WATER LEVEL IN DRILLED WELL

PO LOCATION OF PUMPING PRODUCTION WELL

Figure 73. Estimated potentiometric surface of the fractured-sedimentary-rock aquifer determined from water levels measured in 97 drilled wells in the vicinity of North Penn Area 7 Superfund site, Upper Gwynedd Township, Montgomery County, Pa., December 4-6, 2000. (Modified from Senior and Ruddy, 2004). 
Formation north of North Penn Area 7 in directions similar to the topographic gradient toward the Wissahickon Creek and in a general southwest direction.

\section{Vertical Gradients}

On a local or borehole scale, ground-water flow directions may appear to deviate from regional flow directions. These local-scale deviations may be caused by vertical gradients, nearby pumping, or natural flow through a complex network of fractures in the dipping-bed ground-water system. Where differences in potentiometric head between zones of water-bearing fractures in a well are present, water in the borehole flows vertically from zones of higher head to zones of lower head. The well can act as a short circuit between these different zones, which under natural conditions are separated by layers of unfractured or low-permeability bedrock. An example of vertical borehole flow between producing and receiving fractures is shown in figure 11 for a well (MG-1144) exhibiting upward and downward flow.

In North Penn Area 7, vertical gradients were inferred from borehole flow measured using a heatpulse flowmeter under nonpumping conditions in 15 wells. In 9 of the 15 wells, the direction of vertical gradients was confirmed during aquifer isolation tests discussed in a previous section of this report. The borehole-flow measurements were made in available observation, industrial, commercial and production wells ranging in depth from 51 to $623 \mathrm{ft}$. Of the 15 wells tested, upward borehole flow only was measured in three wells, downward flow only was measured in three wells, both upward and downward flow was measured in two wells, and no detectable flow was measured in seven wells (table 66). All three of the wells with upward flow (and upward vertical gradients) were on the east side of Wissahickon Creek. The wells with downward flow (downward vertical gradients) and mixed upward and downward flow were on the west side of Wissahickon Creek. Flow was not detected in 6 of the 11 shallow wells (less than $85-\mathrm{ft}$ deep). In wells near the Wissahickon Creek, a potential discharge area where upward vertical gradients might be expected, the presence of downward vertical flow and downward gradients may be partly caused by nearby pumping. Wells with downward vertical gradients that may be affected by pumping include MG-202, MG-1144, and MG-1145 (fig. 4).

The spatial distribution of vertical gradients also may be partly controlled by the geometry of dipping beds in the region.

Table 66. Depth of wells, water levels, and heatpulse-flowmeter measurements and direction of borehole flow in wells logged near North Penn Area 7 Superfund site, Upper Gwynedd Township, Montgomery County, Pa.

[Locations of wells are shown on figure 4; ft bls, feet below land surface; gal/min, gallons per minute; --, no measured flow]

\begin{tabular}{|c|c|c|c|c|c|c|c|}
\hline $\begin{array}{c}\text { U.S. } \\
\text { Geological } \\
\text { Survey } \\
\text { local well } \\
\text { number }\end{array}$ & $\begin{array}{l}\text { Depth } \\
\text { of } \\
\text { well } \\
\text { (ft bls) }\end{array}$ & $\begin{array}{c}\text { Depth } \\
\text { to } \\
\text { water } \\
\text { (ft bls) }\end{array}$ & $\begin{array}{c}\text { Depths } \\
\text { where } \\
\text { upward } \\
\text { flow measured } \\
\text { (ft bls) }\end{array}$ & $\begin{array}{l}\text { Range of } \\
\text { upward } \\
\text { flow rates } \\
\text { measured } \\
\text { (gal/min) }\end{array}$ & $\begin{array}{c}\text { Depths } \\
\text { where } \\
\text { downward } \\
\text { flow measured } \\
\text { (ft bls) }\end{array}$ & $\begin{array}{l}\text { Range of } \\
\text { downward } \\
\text { flow rates } \\
\text { measured } \\
\text { (gal/min) }\end{array}$ & $\begin{array}{c}\text { Depths } \\
\text { where } \\
\text { no flow } \\
\text { detected } \\
\text { (ft bls) }\end{array}$ \\
\hline MG-174 & 160 & 34.93 & $83,96,100,122$ & $0.2-0.5$ & -- & -- & 60,140 \\
\hline MG-175 & 103 & 38.83 & -- & -- & -- & -- & $50,70,90$ \\
\hline MG-202 & 623 & 53.32 & 234 & $.0-.4$ & $62,90,142$ & $0.4-0.6$ & 224,262 \\
\hline MG-1144 & 84 & 31.35 & 72,78 & $.3-.6$ & $40,54,64$ & $.1-.4$ & -- \\
\hline MG-1145 & 83 & 26.80 & -- & -- & $\begin{array}{c}35,46,55,59 \\
68,78\end{array}$ & $.2-.6$ & 30 \\
\hline MG-1146 & 84.5 & 37.33 & -- & -- & -- & -- & $44,54,66,76$ \\
\hline MG-1147 & 83.5 & 39.19 & -- & -- & -- & -- & $48,52,62,74$ \\
\hline MG-1148 & 84 & 52.48 & -- & -- & -- & -- & $62,74,80$ \\
\hline MG-1149 & 84 & 51.13 & -- & -- & $62-80$ & $.2-.7$ & -- \\
\hline MG-1505 & 83.2 & 25.94 & $\begin{array}{c}29,52,63,70 \\
76\end{array}$ & $.1-1.0$ & -- & -- & 38 \\
\hline MG-1842 & 86 & 41.18 & -- & -- & 78 & 1.0 & $46,54,66$ \\
\hline MG-1844 & 51.2 & 43.98 & -- & -- & -- & -- & 46 \\
\hline MG-1845 & 54.6 & 44.92 & -- & -- & -- & -- & 49 \\
\hline MG-1846 & 55.9 & 46.19 & -- & -- & -- & -- & 50 \\
\hline MG-1897 & 288 & 24.28 & $\begin{array}{c}72,88,96,112 \\
124,141,170 \\
190\end{array}$ & ${ }^{1} .06-.10$ & -- & -- & $\begin{array}{c}50,58,220 \\
246,270\end{array}$ \\
\hline
\end{tabular}

\footnotetext{
${ }^{1}$ Flow measured using an 8-inch diverter in a 10-inch well underestimates actual flow.
} 
As discussed in Senior and Goode (1999), the upward vertical gradients observed in many wells in Lansdale, an upland, recharge area, might be explained by a series of partially confined to confined beds that dip to the northwest and are recharged by higher elevation areas in the up-dip areas that crop out to the east. In North Penn Area 7, the area east of Wissahickon Creek has a hydrogeologic setting similar to that in Lansdale. However, on the west side of Wissahickon Creek up to the topographic divide nearly coincident with Church Road, beds dip away from the topographic low at the stream level, and downward vertical gradients might be expected for a certain range of well depths. A schematic showing these relations is shown in fig. 74. A similar spatial distribution of vertical gradients is predicted by a conceptual model for dipping beds of differing hydraulic properties (Risser and Bird, 2003, fig. 4).

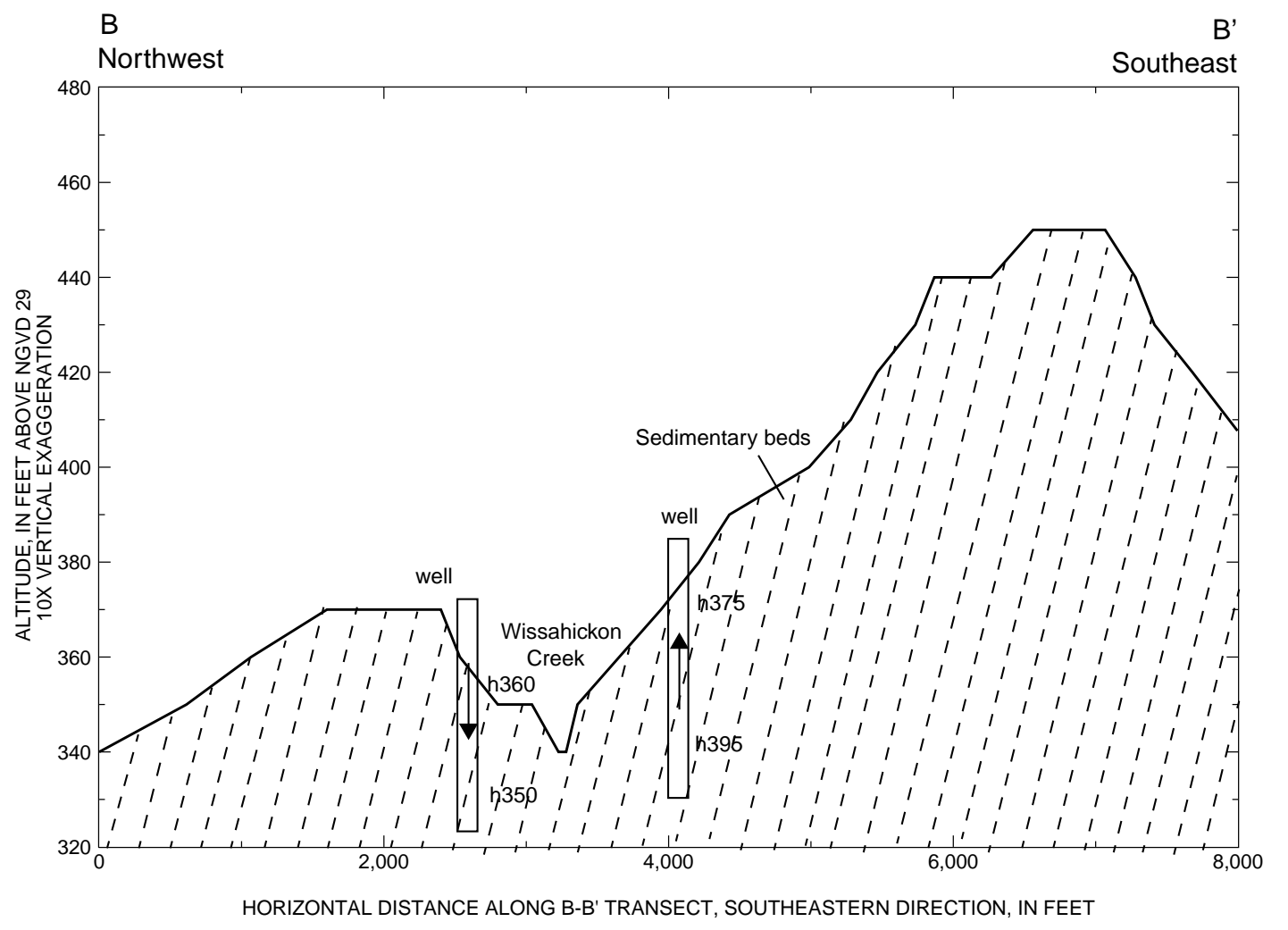

EXPLANATION

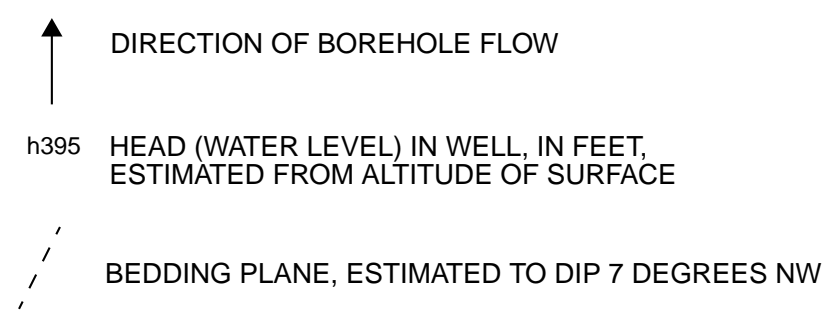

Figure 74. Schematic B-B' transect showing altitude of land surface, geometry of dipping sedimentary beds, two wells on either side of Wissahickon Creek, and possible borehole-flow directions controlled by vertical gradients determined by altitude of recharge area for confined dipping beds, Upper Gwynedd Township, Montgomery County, Pa. Location of transect shown on figure 69. 


\section{Summary}

In 1979, ground water in the area in the vicinity of various industrial facilities in and around Lansdale Borough and Upper Gwynedd Township, Montgomery County, Pa., was found to be contaminated with various volatile organic compounds (VOCs), such as trichloroethylene (TCE), in 1979. After investigation, one area primarily in Upper Gwynedd Township straddling the Wissahickon Creek and about $2 \mathrm{mi}^{2}$ in extent was placed on the National Priorities List as the North Penn Area 7 Superfund site by the U.S. Environmental Protection Agency (USEPA) in 1989. Beginning in autumn 2000, the U.S. Geological Survey (USGS) conducted geophysical logging, aquifer testing, water-level monitoring, and streamflow measurements in the vicinity of North Penn Area 7 to assist the USEPA in developing understanding of the hydrogeologic framework in the area as part of the USEPA Remedial Investigation.

The study area is underlain by Triassic and Jurassic-age sandstones, siltstones, and shales of the Lockatong Formation and the Brunswick Group. Regionally, these rocks strike northeast and dip to the northwest. The sequence of rocks form fractured-sedimentary-rock aquifers that act as a set of confined to partially confined layered aquifers of differing permeabilities. The aquifers are recharged by precipitation and discharge to wells and streams. The Wissahickon Creek has its headwaters just north of the study area and flows south to bisect North Penn Area 7. Ground water is pumped in the vicinity of North Penn Area 7 for industrial use and public supply.

As part of USGS technical assistance to USEPA, 16 wells ranging in depth from 50 to $623 \mathrm{ft}$ were logged. Geophysical logging identified water-bearing zones associated with highangle fractures and bedding-plane openings throughout the depth of the boreholes. More than half of the tentatively identified water-bearing fractures were near intervals of elevated single-point resistance readings (as compared to background) that may be associated with sandstone units. Heatpulse-flowmeter measurements under nonpumping, ambient conditions indicated borehole flow was in the upward direction only in three of the eight wells where flow was detected and in the downward direction only in two wells. In two wells, both upward and downward flow were measured. Wells with upward flow only were on the east side of Wissahickon Creek and wells with some downward flow were on the west side of the creek. The direction of vertical gradients may be related to aquifer structure, consisting of a series of northwest-dipping beds of differing permeabilities. Heatpulse-flowmeter measurements under pumping conditions were used to identify the most productive intervals in wells. Correlation of naturalgamma and single-point-resistance logs indicated bedding in the area probably strikes about 40 degrees NE. and dips 6 to 7 degrees NW. Borehole-deviation logs showed a consistent linear trend to the southeast, which is consistent with bedding that strikes northeast and dips northwest. The orientations of linear features interpreted from acoustic-televiewer logs showed no strong spatial pattern, which may be, in part, because of the difficulty of interpreting low-angle features, such as those that might be associated with bedding.

Isolation-interval testing was done in 9 of the 16 wells that were logged and ranged in depth from 85 to $623 \mathrm{ft}$, for a total of 30 zones tested. Aquifer intervals isolated by inflatable packers were pumped to test productivity and to determine chemical quality of water produced from the interval. Straddlepacker spacings ranged from 8.5 to $23.5 \mathrm{ft}$. The specific capacities of isolated intervals ranged from 0.02 to more than $3.6(\mathrm{gal} / \mathrm{min}) / \mathrm{ft}$, corresponding to estimated transmissivities of 4.4 to $795 \mathrm{ft}^{2} / \mathrm{d}$, respectively. Interval-isolation testing confirmed the presence of vertical gradients indicated by heatpulse-flowmeter measurements. Intervals adjacent to isolated pumped intervals showed little response to pumping. The presence of vertical gradients and lack of adjacent-interval response to pumping in isolated intervals indicate a limited degree of hydraulic connection in the aquifer sections tested. Trichloroethylene (TCE), cis-1,2-dichloroethylene (cis-1,2-DCE), and toluene were the most frequently detected compounds, and other detected compounds included tetrachloroethylene, vinyl chloride, and 1,1,2-trichloro-1,2,2-trifluoroethane. Concentrations up to greater than $340 \mu \mathrm{g} / \mathrm{L} \mathrm{TCE}$, $680 \mu \mathrm{g} / \mathrm{L}$ cis-1,2-DCE, and greater than $590 \mu \mathrm{g} / \mathrm{L}$ toluene were measured in samples from isolated intervals. Concentrations of most VOCs generally were highest in water from the shallowest isolated intervals in wells, although the highest concentrations of TCE were in deeper intervals in two wells and the highest concentrations of toluene were deeper in five wells. Low concentrations of dissolved oxygen, ranging from 0.1 to $3.6 \mathrm{mg} / \mathrm{L}$, were measured in water samples from isolated intervals and may be related to the degradation of VOCs.

A multiple-well aquifer test was conducted by monitoring the response of 14 wells to pumping of a production well in February and March 2002. Results of the aquifer test with multiple observation wells showed water levels in 4 of the 14 wells responded to pumping. The spatial distribution of the four wells that responded to pumping are along strike and in the up-dip and down-dip direction of producing zones of the pumped well. The spatial distribution of the four responding wells indicates that geologic structure has some control over hydraulic connections in the aquifer. Drawdown in the four wells was fitted to Theis curves for wells in confined aquifers of infinite areal extent. However, the early-time drawdown data of the four wells do not fall along the Theis curve and, therefore, suggest that other analytical solutions may be more appropriate, Theis-curve matches for late-time data result in estimates of transmissivity ranging from 773 to $1,625 \mathrm{ft}^{2} / \mathrm{d}$ and estimates of storage coefficient ranging from 0.00003 to 0.0006

Water levels were monitored continuously in three wells in the area. Streamflow was measured quarterly since December 2000 at two sites on Wissahickon Creek. Water-level monitoring in three wells from December 2000 through September 2002 shows the seasonal rise and decline of levels for the period. Water levels rise rapidly (within hours) in response to 
precipitation. Water levels in two wells near Wissahickon Creek were evaluated in relation to streamflow on dates of quarterly streamflow measurements. The Wissahickon Creek was a losing stream between the two measurement sites and ground-water levels were lower than the stream-channel bottom for most dates. Water levels measured in a $16-\mathrm{mi}^{2}$ area around and including North Penn Area 7 during December 2000 indicated the ground-water-level surface is relatively flat in the immediate vicinity of the North Penn Area 7 site and generally is similar to topography except in areas affected by large amounts of pumping. The direction of regional groundwater flow in the fractured-sedimentary-rock aquifer is toward discharge areas of streams and pumping wells.

\section{Acknowledgments}

The cooperation of well owners who made their wells accessible for water sampling, water-level measurements, and geophysical logging is greatly appreciated, especially those owners that allowed repeated sampling or continued monitoring of their wells. The well owners include: NPWA; Merck \& Co., Inc.; Ken Steigelman; and residents in areas in and near Lansdale and Upper Gwynedd Township. William Berry and others of NPWA are recognized for providing information about pumping schedules and coordination in conducting field work. NWWA also provided information about pumping rates and schedules. Robert Cavett and Jason Szefcak of Merck \& Co., Inc. are recognized for providing water-level and other hydrologic data. The cooperation of USEPA project manager Deana Moultrie and USEPA's contractor, Camp, Dresser, and McKee (CDM) Federal Programs Corporation, also was integral to geophysical logging of new monitor wells, disposal of wastewater from aquifer tests, and other aspects of the study.

\section{References Cited}

American Public Health Association, American Water Works Association, and Water Pollution Control Federation, 1976, Standard methods for the examination of water and wastewater: Washington, D.C., 1,193 p.

Barton, G.J., Risser, D.W., Galeone, D.G., and Goode, D.J., 2003, Case study for delineating a contributing area to a well in a fractured siliciclastic-bedrock aquifer near Lansdale, Pennsylvania: U.S. Geological Survey WaterResources Investigations Report 02-4271, 46 p.

Bear, Jacob, 1979, Hydraulics of groundwater: New York, McGraw-Hill, 567 p.

Biesecker, J.E., Lecinsky, J.B., and Wood, C.R., 1968, Water resources of the Schuylkill River Basin: Pennsylvania Department of Environmental Protection Water Resources Bulletin, no. 3, 198 p.
Black \& Veatch Waste Science, Inc., 1994, Remedial Investigation Feasibility Study Report North Penn Area 6 Site Source Control Operable Unit, Lansdale, Pennsylvania. Work assignment no. 91-19-3LW9, contract no. 68-W80091: Prepared for the U.S. Environmental Protection Agency, December 20, 1994.

Bower, E.J., and McCarty, P.H., 1983, Transformations of 1and 2-carbon halogenated aliphatic organic compounds under methanogenic conditions: Applied and Environmental Microbiology, v. 4, no. 4, p. 569-599.

Brown, E.T., Green, S.J., and Sinha, K.P., 1981, The influence of rock anisotropy on hole deviation in rotary drilling-A review: International Journal of Rock Mechanics and Mining Sciences, v. 18, no. 5, p. 387-401.

CH2M-Hill, Inc., 1992, North Penn Area 7 Phase II RI/FS Work Plan. Work assignment no. 05-3LX1.0, contract no. 68-W8-0090: Prepared for the U.S. Environmental Protection Agency, February 1992.

Conger, R.W., 1996, Borehole geophysical logging for waterresources investigation in Pennsylvania: U.S. Geological Survey Fact Sheet 218-95, 2 p.

Conger, R.W., 1999, Evaluation of geophysical logs at North Penn Area 6 Superfund Site, Lansdale, Montgomery County, Pennsylvania: U.S. Geological Survey Open-File Report 99-271A, 149 p.

Converse Consultants East, 1994, Report: Task 2 Investigation of regional and site ground-water quality Ford Electronics and Refrigeration Corporation (FERCO) Church Road Facility, Lansdale, Pennsylvania, Project No. 91-37322-07: Parsippany, N.J., Sept. 20, 1994, 2 vols.

Durlin, R.R., and Schaffstall, W.P., 2002, Water resources data for Pennsylvania, water year 2001, volume 1, Delaware River Basin: U.S. Geological Survey Water-Data Report PA-01-1, 529 p.

Geraghty \& Miller, Inc., 1993, Evaluation of groundwater pumpage and containment at the Merck \& Co., Inc., West Point, Pennsylvania, Plant: Reston, Virginia, Dec. 3, 1993.

Goode, D.J., and Senior, L.A., 1998, Review of aquifer testing information, 1980-1995, North Penn Area 6, Lansdale, Montgomery County, Pennsylvania: U.S. Geological Survey Open-File Report 98-294, 70 p.

Keys, W.S., 1990, Borehole geophysics applied to groundwater investigations: U.S. Geological Survey Techniques of Water-Resources Investigations, book 2, chap. E2, 150 p.

Kruseman, G.P., and de Ridder, N.A., 1990, Analysis and evaluation of pumping test data: Wageningen, The Netherlands, International Institute for Land Reclamation and Improvement, Publication 47, $377 \mathrm{p}$.

Longwill, S.M., and Wood, C.R., 1965, Ground-water resources of the Brunswick Formation in Montgomery and Berks Counties, Pennsylvania: Pennsylvania Geological Survey, 4th ser., Water Resource Report W22, 59 p. 
Lyttle, P.T., and Epstein, J.B., 1987, Geologic map of the Newark $1^{\circ}$ x $2^{\circ}$ Quadrangle, New Jersey, Pennsylvania and New York: U.S. Geological Survey Miscellaneous Investigations Map I-1715, scale 1:250,000.

McLamore, R.T., 1971, The role of rock strength anisotropy in natural hole deviation: Journal of Petroleum Technology, $\mathrm{v}$. 23 , no. 11 , p. 1,313-1,321.

Morin, R.H., Senior, L.A., and Decker, E.R., 2000, Fracturedaquifer hydrogeology from geophysical logs-Brunswick Group and Lockatong Formation, Pennsylvania: Ground Water, no. 2, Mar.-Apr. 2000, p. 182-92.

National Oceanic and Atmospheric Administration, National Climactic Data Center, 2000, Climatological data annual summary Pennsylvania: National Climactic Data Center, Asheville, N.C., v. 105, no. 13, ISSN-0364-5843.

National Oceanic and Atmospheric Administration, National Climactic Data Center, 2001, Climatological data annual summary Pennsylvania: National Climactic Data Center, Asheville, N.C., v. 106, no. 13, ISSN-0364-5843.

National Oceanic and Atmospheric Administration, National Climactic Data Center, 2002a, Monthly station normals of temperature, precipitation, and heating and cooling degree days 1971-2000: National Oceanic and Atmospheric Administration Climatography of the United States no. 81, 36 Pennsylvania, revised 2/02.

National Oceanic and Atmospheric Administration, National Climactic Data Center, 2002b, Climatological Data, Pennsylvania, March 2002: National Climactic Data Center, Asheville, N.C., v. 107, no. 3, ISSN 0354-5843.

Newport, T.G., 1971, Ground-water resources of Montgomery County, Pennsylvania: Pennsylvania Geological Survey, 4th ser., Water Resource Report W29, 83 p.

Rima, D.R., 1955, Ground-water resources of the Lansdale area, Pennsylvania: Pennsylvania Geological Survey, 4th ser., Prog. Report 146, 24 p.

Risser, D.W., and Bird, P.H., 2003, Aquifer tests and simulation of ground-water flow in Triassic sedimentary rocks near Colmar, Bucks and Montgomery Counties, Pennsylvania: U.S. Geological Survey Water-Resources Investigations Report 03-4159, $73 \mathrm{p}$.

Schlische, R.W., 1992, Structural and stratigraphic development of the Newark extional basin, eastern North America-Evidence for growth of the basin and its bounding structures: Geological Society of America Bulletin, v. 104, p. 1,246-1,263.

Senior, L.A., and Goode, D.J., 1999, Ground-water system, estimation of aquifer hydraulic properties, and effects of pumping on ground-water flow in Triassic sedimentary rocks in and near Lansdale, Pennsylvania: U.S. Geological Survey Water-Resources Investigations Report 99-4228, $112 \mathrm{p}$.

Senior, L.A., Rowland, C.A., and Prieto, D.A., 1998, Altitude and configuration of the potentiometric surface in Lansdale and vicinity, Montgomery County, Pennsylvania, August 22-23, 1996: U.S. Geological Survey Open-File Report 98253, 1 plate, scale 1:24,000.

Senior, L.A., and Ruddy, A.J., 2004, Altitude and configuration of the water-level surface in Mesozoic sedimentary rocks at and near the North Penn Area 7 Superfund site, Upper Gwynedd Township, Montgomery County, Pennsylvania: U.S. Geological Survey Open-File Report 1004-1006, 1 plate, scale 1:24,000.

Sevon, W.D., comp., 2000, Physiographic provinces of Pennsylvania: Pennsylvania Geological Survey, 4th ser., map 13, scale 1:2,000,000.

Shapiro, A.M., and Hsieh, P.A., 1998, How good are estimates of transmissivity from slug tests in fractured rock?: Ground Water, v. 36, no. 1, p. 37-48.

Sloto, R.A., and Crouse, M.Y., 1996, HYSEP-A computer program for hydrograph separation and analysis: U.S. Geological Survey Water-Resources Investigations Report 96-4040, $46 \mathrm{p}$.

Theis, C.V., 1935, The relation between the lowering of the piezometric surface and the rate and duration of discharge of a well using ground-water storage: Transactions American Geophysical Union, v. 16, p. 519-524.

Williams, J.H., and Conger, R.W., 1990, Preliminary delineation of contaminated water-bearing fractures intersected by open-hole bedrock wells: Groundwater Monitoring Review, Fall 1990.

Wilson, G.E., 1976, How to drill a usable hole Part 1-Why deviation occurs: World Oil, v. 183, no. 2, p. 40-43.

Wood, W.W., 1976, Guidelines for collection and field analysis of ground-water samples for selected unstable constituents: U.S. Geological Survey Techniques of WaterResources Investigations, book 1, chap. D2, 24 p. 
Table 67. Description of selected wells and water levels in the vicinity of North Penn Area 7 Superfund site. Well depth and casing length listed as originally reported.

[Abbreviations: USGS, U.S. Geological Survey; ft, feet; bls, below land surface; in., inches; gal/min, gallons per minute; (gal/min)/ft; --, no data; Aquifer code: 231BRCK, Brunswick Group; 231LCKG, Lockatong Formation; Driller code: 180, Kohl Bros.; 188, C.S. Garber \& Sons; -221, Phila. Drilling Co.; 226, W. Stothoff; 228, S. Moyer; -407, Findley; 512, Miller Pump; 514, Bollinger]

\begin{tabular}{|c|c|c|c|c|c|c|c|c|c|}
\hline \multirow{2}{*}{$\begin{array}{c}\text { County } \\
\text { code }\end{array}$} & \multirow{2}{*}{$\begin{array}{c}\text { U.S. } \\
\text { Geological } \\
\text { Survey } \\
\text { local well } \\
\text { number }\end{array}$} & \multirow[b]{2}{*}{ Owner } & \multirow[b]{2}{*}{$\begin{array}{c}\text { Other } \\
\text { identifier }\end{array}$} & \multirow[b]{2}{*}{$\begin{array}{c}\text { USGS } \\
\text { station } \\
\text { identification } \\
\text { number }\end{array}$} & \multicolumn{2}{|c|}{ Location (NAD 27) } & \multirow[b]{2}{*}{$\begin{array}{l}\text { Aquifer } \\
\text { code }\end{array}$} & \multirow[b]{2}{*}{$\begin{array}{l}\text { Driller } \\
\text { code }\end{array}$} & \multirow[b]{2}{*}{$\begin{array}{c}\text { Year } \\
\text { well } \\
\text { drilled }\end{array}$} \\
\hline & & & & & $\begin{array}{c}\text { Latitude } \\
\text { (degrees) }\end{array}$ & $\begin{array}{l}\text { Longitude } \\
\text { (degrees) }\end{array}$ & & & \\
\hline BK & 929 & U.S. Geological Survey & -- & 402643075150501 & 402643 & 751505 & 231BRCK & 228 & 1967 \\
\hline BK & 929 & & & & & & & & \\
\hline BK & 1020 & U.S. NADC & -- & 401157075032001 & 401155 & 750307 & 231SCKN & 180 & 1968 \\
\hline BK & 1020 & & & & & & & & \\
\hline MG & 68 & North Penn Water Authority & L-9 & 401415075175101 & 401414 & 751751 & 231BRCK & 514 & 1927 \\
\hline MG & 68 & & & & & & & & \\
\hline MG & 68 & & & & & & & & \\
\hline MG & 72 & North Penn Water Authority & L-13 & 401338075162801 & 401338 & 751628 & 231BRCK & 226 & 1941 \\
\hline MG & 72 & & & & & & & & \\
\hline MG & 72 & & & & & & & & \\
\hline MG & 76 & North Penn Water Authority & L-17 & 401334075163301 & 401334 & 751633 & 231BRCK & 226 & 1949 \\
\hline MG & 89 & Lansdale Tube Co.; FERCO & 1 & 401341075165701 & 401341 & 751657 & 231BRCK & -221 & 1949 \\
\hline MG & 90 & Lansdale Tube Co.; FERCO & 2 & 401337075170001 & 401337 & 751700 & 231BRCK & -221 & 1951 \\
\hline MG & 135 & Lansdale Tube Co.; FERCO & 3 & 401331075170601 & 401331 & 751706 & 231BRCK & -221 & 1953 \\
\hline MG & 147 & Lansdale Tube Co.; FERCO & 4 & 401336075165401 & 401336 & 751654 & 231BRCK & -221 & 1953 \\
\hline MG & 151 & Lansdale Tube Co.; FERCO & 5 & 401332075165201 & 401330 & 751652 & 231BRCK & -221 & 1954 \\
\hline MG & 171 & Precision Tube & 1 & 401328075170101 & 401329 & 751702 & 231BRCK & -221 & 1952 \\
\hline MG & 171 & & & & & & & & \\
\hline MG & 171 & & & & & & & & \\
\hline MG & 171 & & & & & & & & \\
\hline MG & 174 & Kleen Products; Clearline & CL-2 & 401315075164901 & 401313.9 & 751648.5 & 231BRCK & -407 & 1950 \\
\hline MG & 174 & Steigelman, Ken & & & & & & -- & -- \\
\hline MG & 175 & Kleen Products; Spra-Fin & 1 & 401306075164401 & 401305.7 & 751644.7 & 231BRCK & -- & -- \\
\hline MG & 175 & & & & & & & & \\
\hline MG & 202 & North Penn Water Authority & $\mathrm{L}-22$ & 401329075164001 & 401326 & 751643 & 231BRCK & 226 & 1955 \\
\hline MG & 204 & Precision Tube & 2 & 401328075170401 & 401328 & 751704 & 231BRCK & -221 & 1955 \\
\hline MG & 1144 & Teleflex, Inc. & $\mathrm{T}-13$ & 401314075171801 & 401312.9 & 751715.7 & 231BRCK & 512 & 1986 \\
\hline MG & 1144 & & & & & & & & \\
\hline MG & 1145 & Teleflex, Inc. & $\mathrm{T}-14$ & 401314075171401 & 401312.2 & 751711.8 & 231BRCK & 512 & 1986 \\
\hline MG & 1145 & & & & & & & & \\
\hline MG & 1146 & Teleflex, Inc. & $\mathrm{T}-4$ & 401318075171101 & 401319.0 & 751711.3 & 231BRCK & 512 & 1986 \\
\hline MG & 1146 & & & & & & & & \\
\hline MG & 1147 & Teleflex, Inc. & $\mathrm{T}-11$ & 401322075171201 & 401322.3 & 751711.9 & 231BRCK & 512 & 1986 \\
\hline MG & 1147 & & & & & & & & \\
\hline MG & 1148 & Teleflex, Inc. & $\mathrm{T}-12$ & 401324075171601 & 401323.6 & 751715.5 & 231BRCK & 512 & 1986 \\
\hline MG & 1148 & & & & & & & & \\
\hline MG & 1149 & Teleflex, Inc. & $\mathrm{T}-10$ & 401321075171701 & 401321.6 & 751717.3 & 231BRCK & 512 & 1986 \\
\hline MG & 1149 & & & & & & & & \\
\hline MG & 1505 & Huey, William & -- & 401309075165401 & 401309 & 751655 & 231BRCK & -- & \\
\hline MG & 1841 & Spra-Fin & 2 & 401308075165401 & 401307.47 & 751644.55 & 231BRCK & -- & \\
\hline MG & 1841 & & & & & & & & \\
\hline
\end{tabular}


Table 67. Description of selected wells and water levels in the vicinity of North Penn Area 7 Superfund stie. Well depth and casing length listed as originaly reported.-Continued

[Abbreviations: USGS, U.S. Geological Survey; ft, feet; bls, below land surface; in., inches; gal/min, gallons per minute; (gal/min)/ft; --, no data; Aquifer code: 231BRCK, Brunswick Group; 231LCKG, Lockatong Formation; Driller code: 180, Kohl Bros.; 188, C.S. Garber \& Sons; -221, Phila. Drilling Co.; 226, W. Stothoff; 228, S. Moyer; -407, Findley; 512, Miller Pump; 514, Bollinger; VD29, NGVD1929]

\begin{tabular}{|c|c|c|c|c|c|c|c|c|c|c|}
\hline \multirow{2}{*}{$\begin{array}{l}\text { Altitude } \\
\text { of } \\
\text { land- } \\
\text { surface, } \\
\text { (ft, VD29) }\end{array}$} & \multirow{2}{*}{$\begin{array}{l}\text { Well } \\
\text { depth } \\
\text { (ft bls) }\end{array}$} & \multicolumn{2}{|c|}{ Casing } & \multirow[b]{2}{*}{$\begin{array}{c}\text { Reported } \\
\text { yield } \\
\text { (gal/min) }\end{array}$} & \multirow{2}{*}{$\begin{array}{c}\text { Specific } \\
\text { capacity } \\
{[(\mathrm{gal} / \mathrm{min}) /} \\
\mathrm{ft}]\end{array}$} & \multirow{2}{*}{$\begin{array}{c}\text { Length } \\
\text { of } \\
\text { test } \\
\text { (hours) }\end{array}$} & \multirow{2}{*}{$\begin{array}{c}\text { Depth } \\
\text { to } \\
\text { water } \\
\text { (ft bls) }\end{array}$} & \multirow{2}{*}{$\begin{array}{c}\text { Date } \\
\text { of } \\
\text { water } \\
\text { level } \\
\text { measurement }\end{array}$} & \multirow[b]{2}{*}{$\begin{array}{l}\text { County } \\
\text { code }\end{array}$} & \multirow{2}{*}{$\begin{array}{c}\text { U.S. } \\
\text { Geological } \\
\text { Survey } \\
\text { local well } \\
\text { number }\end{array}$} \\
\hline & & $\begin{array}{l}\text { Length } \\
\text { (ft) }\end{array}$ & $\begin{array}{l}\text { Diameter } \\
\text { (in.) }\end{array}$ & & & & & & & \\
\hline \multirow[t]{2}{*}{490} & 129 & 27 & 6 & 17 & 0.85 & 1 & 58.74 & 19670627 & BK & 929 \\
\hline & & & & & & & 45.58 & 20000927 & BK & 929 \\
\hline \multirow[t]{2}{*}{370} & 395 & 57 & 10 & 90 & .8 & 24 & 40 & 19680413 & $\mathrm{BK}$ & 1020 \\
\hline & & & & & & & 34.28 & 20001127 & BK & 1020 \\
\hline \multirow[t]{3}{*}{322.6} & 500 & 250 & 8 & 79 & -- & -- & 83 & 19470131 & $\mathrm{MG}$ & 68 \\
\hline & & & & & & & 39.72 & 19960823 & $\mathrm{MG}$ & 68 \\
\hline & & & & & & & 37.11 & 20001205 & MG & 68 \\
\hline \multirow[t]{3}{*}{356.0} & 306 & 44 & 10 & 128 & -- & -- & 42 & 19470301 & $\mathrm{MG}$ & 72 \\
\hline & & & & & & & 35.44 & 19960823 & MG & 72 \\
\hline & & & & & & & 46.07 & 20001205 & MG & 72 \\
\hline 350 & 388 & 37 & 12 & 240 & 2.55 & 50 & 23 & 19490718 & MG & 76 \\
\hline 382 & 698 & 40 & 8 & 96 & .65 & 48 & 50 & 19490920 & MG & 89 \\
\hline 375 & 500 & 46 & 8 & 165 & 1.27 & 49 & 57 & 19510117 & MG & 90 \\
\hline 370 & 500 & - & 6 & 150 & 1.63 & -- & 85 & 19530817 & MG & 135 \\
\hline 376 & 500 & - & 8 & 150 & 1.91 & -- & 85 & 19540826 & MG & 147 \\
\hline 361 & 500 & 78 & 8 & 185 & -- & 30 & 100 & 19541106 & MG & 151 \\
\hline \multirow[t]{4}{*}{366} & 500 & 68 & 8 & -- & -- & -- & 117 & 19541012 & MG & 171 \\
\hline & & & & & & & 26.91 & 19960805 & MG & 171 \\
\hline & & & & & & & 27.1 & 19960823 & MG & 171 \\
\hline & & & & & & & 53.5 & 20000500 & MG & 171 \\
\hline \multirow[t]{2}{*}{347.63} & 144 & 34 & 6 & 36 & -- & -- & 25 & 19500408 & MG & 174 \\
\hline & & & & & & & 32.93 & 20001205 & MG & 174 \\
\hline \multirow[t]{2}{*}{362.25} & 160 & -- & 6 & -- & -- & -- & 34.92 & 20001031 & MG & 175 \\
\hline & & & & & & & 38.96 & 20001205 & MG & 175 \\
\hline 347 & 647 & -- & 12 & 282 & -- & -- & 54 & 19550119 & MG & 202 \\
\hline 365 & 500 & 66 & 8 & 190 & 8.6 & 50 & 52 & 19550519 & MG & 204 \\
\hline \multirow[t]{2}{*}{336.32} & 85 & - & 6 & & -- & & 20.9 & 19890414 & MG & 1144 \\
\hline & & & & & & & 29.36 & 20001205 & $\mathrm{MG}$ & 1144 \\
\hline \multirow[t]{2}{*}{331.55} & 85 & -- & 6 & -- & -- & -- & 14.78 & 19890414 & MG & 1145 \\
\hline & & & & & & & 24.18 & 20001205 & MG & 1145 \\
\hline \multirow[t]{2}{*}{344.7} & 85 & -- & 6 & -- & -- & -- & 32.7 & 19890414 & MG & 1146 \\
\hline & & & & & & & 34.26 & 20001205 & MG & 1146 \\
\hline \multirow[t]{2}{*}{352.1} & 85 & -- & 6 & -- & -- & -- & 42.24 & 19890414 & MG & 1147 \\
\hline & & & & & & & 41.49 & 20001205 & MG & 1147 \\
\hline \multirow[t]{2}{*}{361.6} & 85 & -- & 6 & -- & -- & -- & 54.16 & 19890414 & MG & 1148 \\
\hline & & & & & & & 51.21 & 20001205 & MG & 1148 \\
\hline 358.9 & 85 & -- & 6 & -- & -- & -- & 49.16 & 19890414 & MG & 1149 \\
\hline & & & & & & & 49.51 & 20001205 & MG & 1149 \\
\hline 351 & 79.6 & -- & -- & -- & -- & -- & 22.06 & 19960726 & MG & 1505 \\
\hline 361.58 & 100 & -- & 5.5 & -- & -- & -- & 36.4 & 20001031 & MG & 1841 \\
\hline & & & & & & & 38.32 & 20001205 & MG & 1841 \\
\hline
\end{tabular}


Table 67. Description of selected wells and water levels in the vicinity of North Penn Area 7 Superfund site. Well depth and casing length listed as originally reported.-Continued

[Abbreviations: USGS, U.S. Geological Survey; ft, feet; bls, below land surface; in., inches; gal/min, gallons per minute; (gal/min)/ft; --, no data; Aquifer code: 231BRCK, Brunswick Group; 231LCKG, Lockatong Formation; Driller code: 180, Kohl Bros.; 188, C.S. Garber \& Sons; -221, Phila. Drilling Co.; 226,

W. Stothoff; 228, S. Moyer; -407, Findley; 512, Miller Pump; 514, Bollinger]

\begin{tabular}{|c|c|c|c|c|c|c|c|c|c|}
\hline \multirow{2}{*}{$\begin{array}{l}\text { County } \\
\text { code }\end{array}$} & \multirow{2}{*}{$\begin{array}{c}\text { U.S. } \\
\text { Geological } \\
\text { Survey } \\
\text { local well } \\
\text { number }\end{array}$} & \multirow[b]{2}{*}{ Owner } & \multirow[b]{2}{*}{$\begin{array}{c}\text { Other } \\
\text { identifier }\end{array}$} & \multirow[b]{2}{*}{$\begin{array}{c}\text { USGS } \\
\text { station } \\
\text { identification } \\
\text { number }\end{array}$} & \multicolumn{2}{|c|}{ Location (NAD 27) } & \multirow[b]{2}{*}{$\begin{array}{l}\text { Aquifer } \\
\text { code }\end{array}$} & \multirow[b]{2}{*}{$\begin{array}{l}\text { Driller } \\
\text { code }\end{array}$} & \multirow[b]{2}{*}{$\begin{array}{c}\text { Year } \\
\text { well } \\
\text { drilled }\end{array}$} \\
\hline & & & & & $\begin{array}{l}\text { Latitude } \\
\text { (degrees) }\end{array}$ & $\begin{array}{l}\text { Longitude } \\
\text { (degrees) }\end{array}$ & & & \\
\hline MG & 1841 & & & & & & & & \\
\hline MG & 1842 & Teleflex, Inc. & $\mathrm{T}-15$ & 401323075171201 & 401320.57 & 751711.77 & 231BRCK & -- & \\
\hline MG & 1842 & & & & & & & & \\
\hline MG & 1843 & Teleflex, Inc. & $\mathrm{T}-6$ & 401320075171101 & 401319.36 & 751708.64 & 231BRCK & -- & -- \\
\hline MG & 1843 & & & & & & & & \\
\hline MG & 1844 & Fitzpatrick Container & -- & 401302075163301 & 401300.88 & 751633.41 & 231LCKG & -- & -- \\
\hline MG & 1844 & & & & & & & & \\
\hline MG & 1845 & Fitzpatrick Container & -- & 401300075163401 & 401300.31 & 751633.37 & 231LCKG & -- & -- \\
\hline MG & 1845 & & & & & & & & \\
\hline MG & 1846 & Fitzpatrick Container & -- & 401305075163601 & 401304.3 & 751635.7 & 231LCKG & -- & -- \\
\hline MG & 1846 & & & & & & & & \\
\hline MG & 1847 & Precision Tube Co. & -- & 401329075165701 & 401328.5 & 751656.6 & 231BRCK & 188 & 1998 \\
\hline MG & 1848 & Precision Tube Co. & -- & 401323075165601 & 401322.4 & 751655.5 & 231BRCK & 188 & 1998 \\
\hline MG & 1849 & Precision Tube Co. & -- & 401324075165401 & 401323.2 & 751653.6 & 231BRCK & 188 & 1998 \\
\hline MG & 1897 & Steigelman, Ken & CL-3 & 401317075165201 & 401317 & 751652 & 231BRCK & -- & -- \\
\hline MG & 1897 & & & & & & & & \\
\hline MG & 1897 & & & & & & & & \\
\hline
\end{tabular}


Table 67. Description of selected wells and water levels in the vicinity of North Penn Area 7 Superfund site. Well depth and casing length listed as originaly reported.-Continued

[Abbreviations: USGS, U.S. Geological Survey; ft, feet; bls, below land surface; in., inches; gal/min, gallons per minute; (gal/min)/ft; --, no data; Aquifer code: 231BRCK, Brunswick Group; 231LCKG, Lockatong Formation; Driller code: 180, Kohl Bros.; 188, C.S. Garber \& Sons; -221, Phila. Drilling Co.; 226, W. Stothoff; 228, S. Moyer; -407, Findley; 512, Miller Pump; 514, Bollinger; VD29, NGVD1929]

\begin{tabular}{|c|c|c|c|c|c|c|c|c|c|c|}
\hline \multirow{2}{*}{$\begin{array}{l}\text { Altitude } \\
\text { of } \\
\text { land- } \\
\text { surface } \\
\text { (ft, VD29) }\end{array}$} & \multirow[b]{2}{*}{$\begin{array}{c}\text { Well } \\
\text { depth } \\
\text { (ft bls) }\end{array}$} & \multicolumn{2}{|c|}{ Casing } & \multirow[b]{2}{*}{$\begin{array}{c}\text { Reported } \\
\text { yield } \\
\text { (gal/min) }\end{array}$} & \multirow{2}{*}{$\begin{array}{c}\text { Specific } \\
\text { capacity } \\
{\left[\begin{array}{c}\text { [gal/min)/ } \\
\mathrm{ft}]\end{array}\right.}\end{array}$} & \multirow{2}{*}{$\begin{array}{c}\text { Length } \\
\text { of } \\
\text { test } \\
\text { (hours) }\end{array}$} & \multirow{2}{*}{$\begin{array}{c}\text { Depth } \\
\text { to } \\
\text { water } \\
\text { (ft bls) }\end{array}$} & \multirow{2}{*}{$\begin{array}{c}\text { Date } \\
\text { of } \\
\text { water } \\
\text { level } \\
\text { measurement }\end{array}$} & \multirow[b]{2}{*}{$\begin{array}{c}\text { County } \\
\text { code }\end{array}$} & \multirow{2}{*}{$\begin{array}{c}\text { U.S. } \\
\text { Geological } \\
\text { Survey } \\
\text { local well } \\
\text { number }\end{array}$} \\
\hline & & $\begin{array}{l}\text { Length } \\
\text { (ft) }\end{array}$ & $\begin{array}{l}\text { Diameter } \\
\text { (in.) }\end{array}$ & & & & & & & \\
\hline \multirow[t]{2}{*}{348.9} & 85 & 18 & 6 & -- & -- & -- & 39.99 & 20001113 & MG & 1842 \\
\hline & & & 8 & & & & 39.26 & 20001205 & MG & 1842 \\
\hline \multirow[t]{2}{*}{340.82} & 38 & 19 & 6 & -- & -- & -- & 29.28 & 20001113 & MG & 1843 \\
\hline & & & & & & & 28.26 & 20001205 & MG & 1843 \\
\hline \multirow[t]{2}{*}{371.67} & 51 & 14.5 & 6 & -- & -- & -- & 39.28 & 20001102 & MG & 1844 \\
\hline & & & & & & & 42.9 & 20001205 & MG & 1844 \\
\hline \multirow[t]{2}{*}{373.14} & 54 & 19 & - & -- & -- & - & 41.9 & 20001102 & MG & 1845 \\
\hline & & & & & & & 45.8 & 20001205 & MG & 1845 \\
\hline \multirow[t]{2}{*}{372.19} & 56 & 21 & - & -- & -- & -- & 41.5 & 20001102 & MG & 1846 \\
\hline & & & & & & & 46.42 & 20001205 & MG & 1846 \\
\hline 357.09 & 60 & 35 & 4 & -- & -- & -- & 43.9 & 20001205 & MG & 1847 \\
\hline 350.26 & 55 & 40 & 4 & 0.5 & 0.06 & -- & 36.91 & 20001205 & MG & 1848 \\
\hline 348.93 & 50 & 35 & 4 & .5 & .03 & -- & 33.63 & 20001205 & MG & 1849 \\
\hline \multirow[t]{3}{*}{337.09} & 288 & 44 & - & -- & -- & -- & 31.58 & 20010917 & MG & 1897 \\
\hline & & & & & & & 28.91 & 20020102 & MG & 1897 \\
\hline & & & & & & & 18.34 & 20020325 & MG & 1897 \\
\hline
\end{tabular}

